\title{
Places of Trade, Communication and Religion-Important Oases
}

\author{
Jacqueline Passon, Klaus Braun, Said Hamid, Salih al-Mahdi Khalifa, \\ Najmiya as-Sadeq at-Tellisi, Mansour El Nayedh, and Joschua Metzger
}

\subsection{Tripoli-Mediterranean Port and Trading Centre}

Jacqueline Passon and Klaus Braun

Tripoli is located in the northwestern part of Libya on the edge of the desert, on a point of rocky land that projects into the Mediterranean and forms a bay. The city is known as Tarabulus al-Gharb (West) to distinguish it from its Phoenician sister city Tripoli in Lebanon which is known in Arabic as Tarabulus al-Sham.

\subsubsection{On the Lee Side of a Cape}

The African coast between Lesser Syrtis and Greater Syrtis is almost flat and sandy everywhere. In the eighth century $\mathrm{BC}$ - probably even earlier-Phoenician merchants began to establish commercial settlements on the North African coast which were used seasonally. The merchants established their commercial stations where their ships could safely anchor on the lee side of a cape, where trade routes from the south reached the coast and where there was also a fertile hinterland. Probably, they called one of these stations Macar Uiat. In the course of time, this trading centre developed into a city that should become known as Oea/Tripoli later on. The expansion of the settlement might have been connected with the rise of Carthage at the end of the sixth century BC when Carthage started to expand its influence in the Mediterranean and founded several colonies. Among these colonies are also the two sister cities of Leptis Magna and Sabratha. After the fall of Carthage, the Romans prepared themselves to subdue

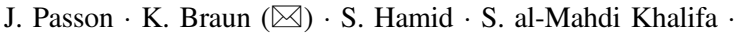

N. as-Sadeq at-Tellisi · M. El Nayedh · J. Metzger

Dept. of Physical Geography, University of Freiburg, Freiburg,

Baden-Württemberg, Germany

e-mail: klaus.braun@geographie.uni-freiburg.de

J. Passon

e-mail: jacqueline.passon@geographie.uni-freiburg.de the Mediterranean countries in the second century BC. At first, the emporia (the Carthaginian trading towns were known as emporia) - which were completely integrated in the Mediterranean trade dominated by Rome-were left to the Numidians. Their subjugation was followed by the integration into the administrative structure of the Roman Empire. Henceforth, Oea belonged to the Roman province of Africa Proconsularis (Fig. 6.1).

In late antiquity, Oea, Sabratha and Leptis Magna experienced once again organised urban living under Byzantine rule. But only Oea, under its new name Tripoli (Arabic: Tarabulus), was to survive the different Arab attacks. Under the command of Amr Ibn al-As, Tripolitania was conquered in the years 642/643. Leptis Magna and Sabratha continued to exist until the eleventh century as Arab strongholds. However, subsequently they were buried by sand. Unlike in Egypt or Tunisia, the urban culture introduced by the Greeks, the Phoenicians and by the Romans found a gradual end in Tripolitania and Cyrenaica. Tripoli, as the only continuously used place of settlement, was rebuilt several times. The road network of the Medina, however, reveals the planning of the Roman colonia - the term denotes the highest status of a Roman city - in its main lines. As one can see in the map Tripoli at the dawn of the twentieth century, the decumanus that leads up from the harbour is still clearly visible in the modern road network. At the triumphal Arch of Marc Aurel and Lucius Verus (22) (Fig. 6.6), which remained as an architectural relict of the Roman era, the northern decumanus cuts a parallel axis of the cardo. ${ }^{1}$ In Roman city planning, a decumanus was an east-west-oriented road and the cardo was a north-south-oriented street. There is every reason to suspect that this area constituted the principal public centre of the Roman settlement. It has been a constant feature in the urban fabric of Tripoli. According to archaeological findings and to the writings of Leo Africanus, a diplomat and author of the sixteenth century, as well as to the topography of the site, the Punic and later Roman settlement might be expected to lie in the area north and 


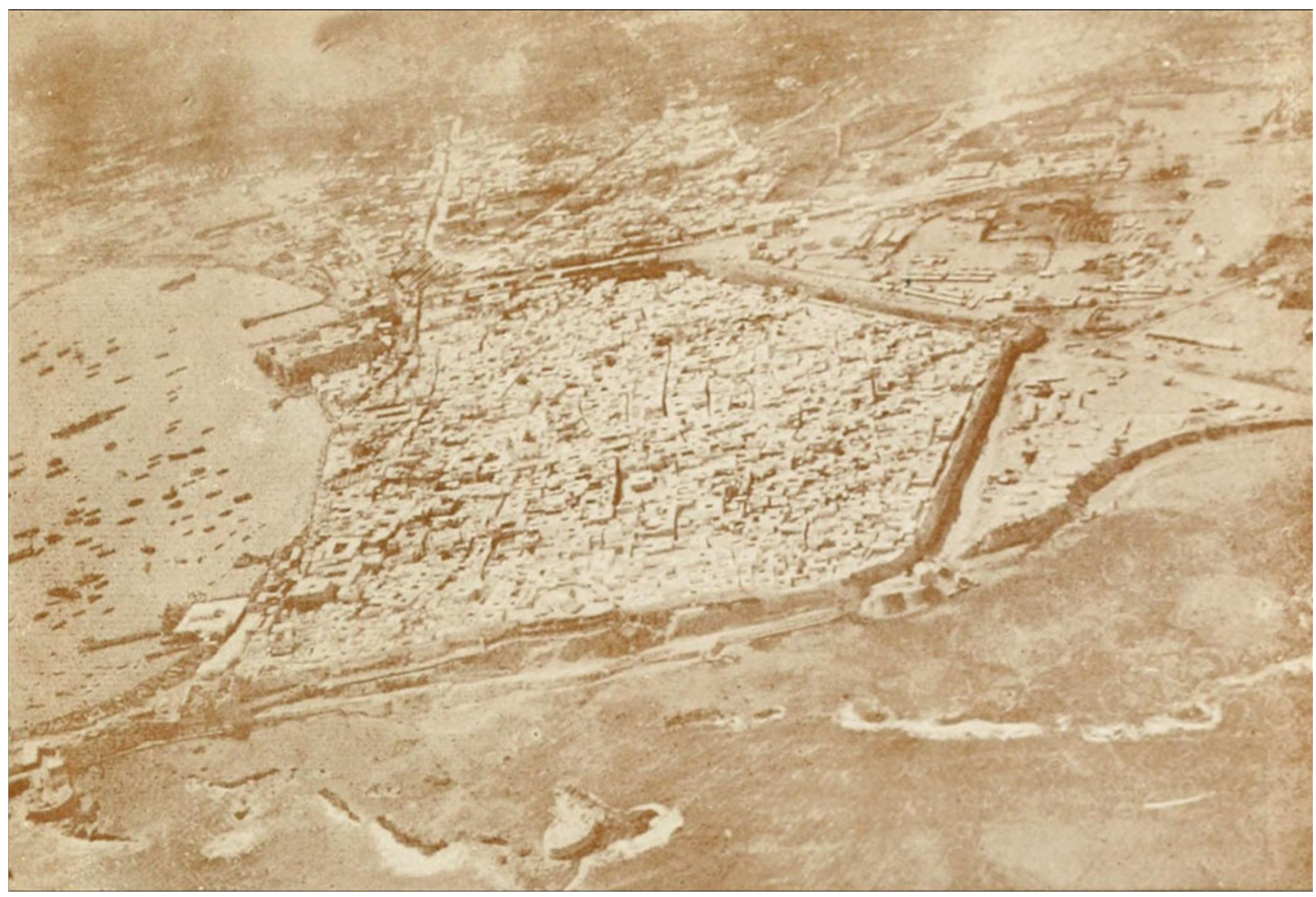

Fig. 6.1 Tripoli is called the "white town by the Mediterranean Sea." The photograph shows one of the first areal photographs taken from Tripoli in 1913 (Tittoni 1913, 95)

north-west of the Roman arch. Here, the promontory on which the city was built narrows considerably, and there are protected anchorages on both sides of it. Today, the highest point is marked by the water tower. On the eastern site of the headland, the harbour facilities of ancient Oea can be found (Fig. 6.2). ${ }^{2}$

\subsubsection{The Arab-Islamic Medina Begins to Take Shape}

After the successful attack of Amr Ibn al-As in the seventh century, Tripoli became an Arab-Islamic Medina and changed its appearance. The second decumanus gained significance and its intersection with the cardo became the public centre of the city. The intersection was highlighted and architecturally defined by the so-called Arbaa Arsat (four-column crossroads) 1 (Fig. 6.3), recalling the Tetrapylon by Marcus Aurelius. On the corners of the crossing, four remains of roman columns were used. Yet another change became visible: as in many Arab-Islamic cities, the layout of most of the streets followed an irregular pattern (Fig. 6.4). ${ }^{3}$

We learn from Ibn Khaldun that the time after the Arab invasion in the seventh century was characterised by numerous politico-religious revolts, in which mainly the Ibadi played a central role. This sect was able to win many followers among the Hawwara and Zanata Berbers, who formed the predominant element in the population. After the end of the Umayyad dynasty (661-750), the Islamic central state disintegrated into territories that gained independence and was ruled by dynasties. Tripolitania no longer was an independent power base, but was now dependent on the development of the more powerful neighbouring regions. Extremely detrimental to urban life was the invasion of the nomadic Arab tribes of Banu Hilal and Banu Sulaym in the eleventh century. During that time, Tripolitania experienced nomadisation again. Politically, Tripoli was controlled for a short intermezzo by the Normans (1146-1158) and then since the middle of the twelfth century by the Berber dynasty 


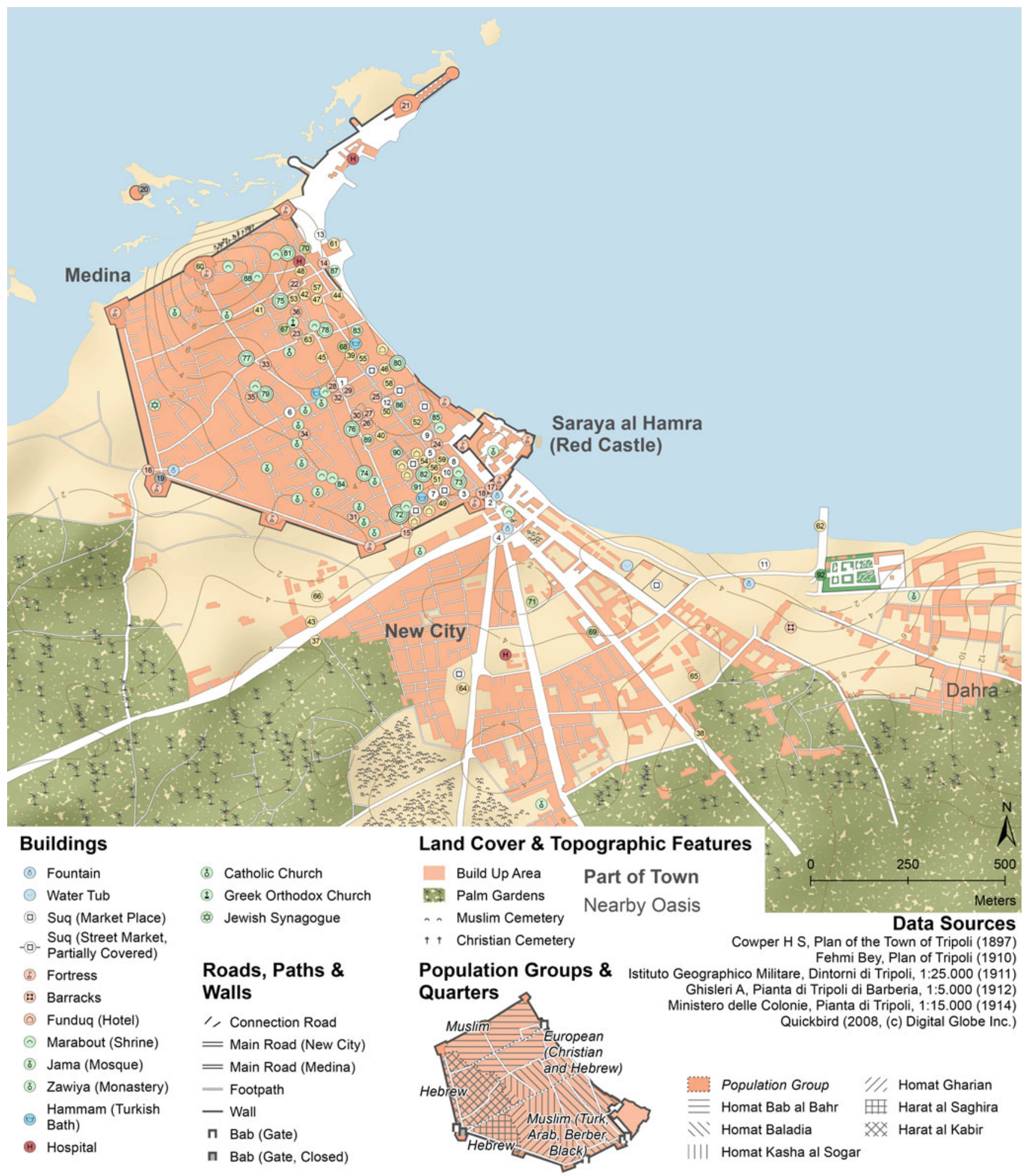

Fig. 6.2 Map of Tripoli: Tripoli at the dawn of the twentieth century 


\section{Important Places}

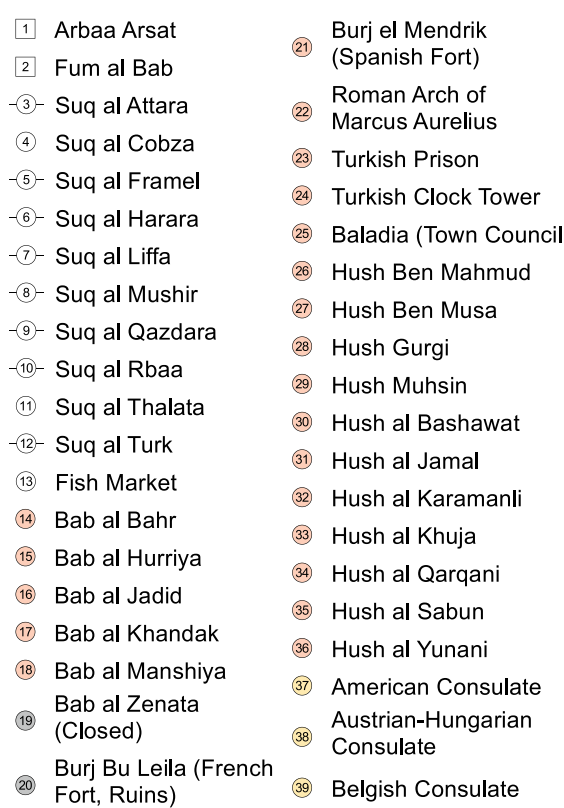

Fig. 6.2 (continued)

(40) Dutch \& Norwegian
(41) English Consulate
(42) French Consulate
(43) German Consulate
(44) Greece Consulate
(45) Italian Consulate
(46) Spanish Consulate
(47) Funduq Baishu
(48) Funduq Bent al Sayyid
(49) Funduq Benzekri
(50) Funduq Hinshiri
(51) Funduq Huwas
(52) Funduq Mady al Hasan
(53) Funduq Zummit
(54) Funduq al Adluni
(55) Funduq al Ghadamsi
(56) Funduq al Ghadamsiya
(57) Funduq al Karamanli
(58) Funduq al Kebir
(59) Funduq al Zahr

60) Light House

(61) Custom Office

(62) Esparto Wharf

(63) Banco di Roma

(64) Italian Ice Making Works

(65) Italian Steam Mill

(66) Italian Tannery

67) Franciscan School

(68) Nuns School

Turkish Arts and

Crafts School

(70) Turkish Navy School

(71) Turkish School

(72) Jama, Kuttab \& Zawiya

Atiyya al Fallah

Jama \& Kuttab Ahmad

Pasha al Karamanli

(74) Jama \& Kuttab Ben Tabun

(75) Jama \& Kuttab Gurgi

(76) Jama \& Kuttab Huriyya

Jama \& Kuttab Mahmud

Khazandar

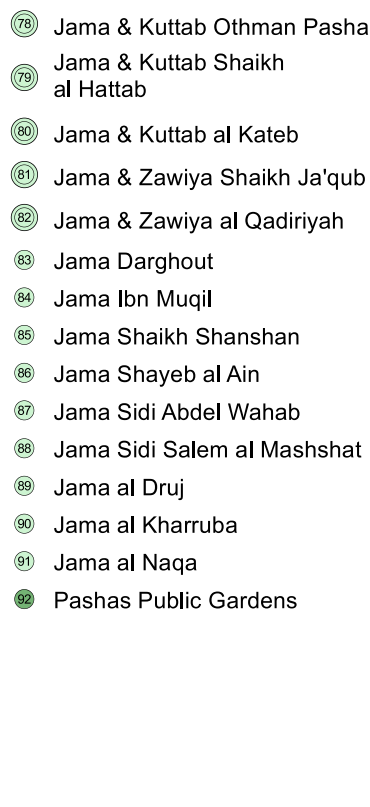

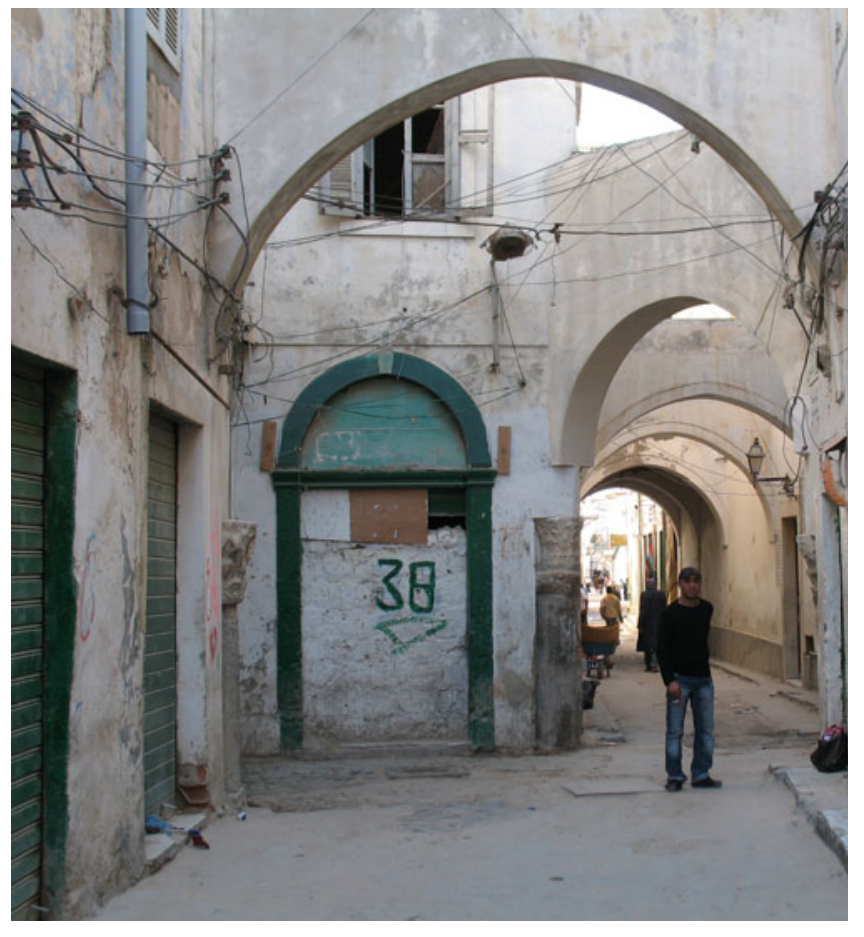

Fig. 6.3 Four-column street, Arbaa Arsat 1 in the Medina of Tripoli

of the Almohads (1158-1248). After their collapse, the Hafsids residing in Tunis managed to use their influence on Tripoli until the early sixteenth century (1248-1510). ${ }^{4}$

Al-Tijani, on his occasion of his travel to the holy lands in 1307-08, states in his travel accounts, Rihlah, that "the

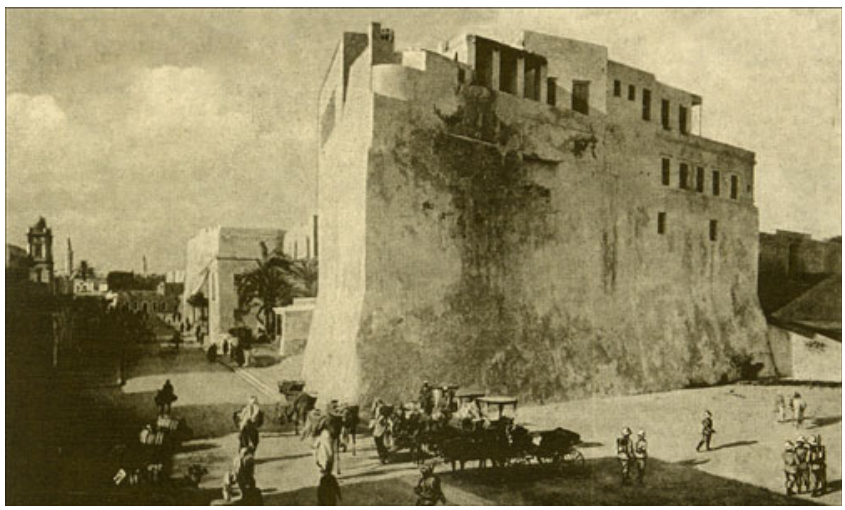

Fig. 6.4 Kasbah at the end of the Ottoman period (Laronde 1997)

streets in the city were clean, and larger than other places, extending from one end to the other of the city and intersected as a chessboard, and easy to go through." 5 His writings bear eloquent testimony to a flourishing place. He describes that Tripoli was administered by a Hafsid governor, living in the castle (kasbah), and a council of 10 notables (shaikh). He also observed a fine bath (hammam), a Great Mosque (al-djami al-azam), many shrines, and a madrasa (al-madrasa al-mustansiriya). He found strong walls in good repair, with a moat in some parts and he admired the Arch of Marcus Aurelius (22). In his mind, the city's intellectual life was flourishing at this time; cultivated people abounded. ${ }^{6}$

A unique building also hails from the Hafsid period (thirteenth-sixteenth century) which can be found in the Bab 
al Bahr area, opposite to the harbour in the immediate vicinity of the Marc Aurel arch. The mosque of Sidi Abdel Wahab al Qyasi 87) (Fig. 6.7), which is distinguished by a unique architectural design compared to other mosques of the old town, originally served as a ribat. This is an Arabic expression for small fortifications that were built on the border of the Islamic sphere of influence. The construction of a fortress or the extension of an existing ribat was considered as pious work. The inhabitants of the fortresses were not only combat-ready soldiers, but also scholars who devoted themselves to the moral support of the troops. The military and religious character of such a building is also reflected in the architecture. Apart from accommodation and storage facilities, such buildings also had a mosque. The function of the ribat changed in the eleventh century. The fortifications then served to protect commercial routes, and as centres for isolated Muslim communities. The ribat tradition may be one of the early sources of the Sufi mystic brotherhoods, and a type of the later zawiya. Here, the homes of marabouts, who are religious teachers, are termed ribat. Concerning the building in Tripoli, which is indeed a small ribat, it is considered to be the marabout tomb of Sidi Abdel Wahab al Qyasi, who was buried at the tomb adjacent to the mosque, which is mentioned by Al-Tijani in his travel book. $^{7}$

\subsubsection{Spanish Intermezzo}

In the fourteenth and fifteenth centuries, the balance of power in the Western Mediterranean shifted to the detriment of the Arabs. In 1492, the last Arab bastion on Spanish soil fell with Granada. In the course of the Reconquista, the Spanish rulers also spread to Northern Africa where they managed to gain several bases. One of these bases was Tripoli which was conquered on 25 July 1510 and managed by a Spanish governor. Pedro Navaro, a Spanish military engineer who led the Spanish forces during the conquest of Tripoli in 1510, describes the city as follows: "This city is larger than what I thought, and although those who admired it spoke well about it, I can see that they were saying only half the truth; and among all the cities I have seen in the world, I do not find any that is comparable to it, both for its fortifications and its cleanliness. It seems rather an imperial city than a city that belongs to any king in particular." 8 Emperor Charles V gave the city to the Knights of St. John as fief; however, already in 1551, it was to be reconquered by the Ottomans. It is worth mentioning from this period that the Knights of St. John converted the kasbah. A castle of the Knights of St. John with Spanish and Turkish features was then built on the medieval fort. Its present structure dates back to the end of the fourteenth century, and it is called the Saraya al hamra (the red castle) because it used to be painted with an almost red colour. The castle is one of the major fortifications of the city and served as a defence centre against hostile naval attacks. Following the revolution in 1969, a museum was built in the tunnel of the castle to host Libyan antiquities and heritage throughout the ages. ${ }^{9}$

Leo Africanus who visited Northern Africa at the beginning of the sixteenth century (1518) identified Tripoli as an important and busy trading centre in the Mediterranean region: "Tripoli was built by the Africans after the destruction of Old Tripoli. It has fine walls, but they are not very strong. It lies in a sandy plain where there are many stands of date-palms. The houses of this city are imposing compared with those of Tunis, and similarly the public spaces are orderly and well-provided with various trades, most notably weavers of cloth. ... Nevertheless, these people do much trade, because their city is close to Numidia and to Tunis, and because there is no other city but this one right up to Alexandria. It is also close to Sicily and Malta, and yearly visits to the port by the Venetian trading galleys are encouraged. The Venetians, as well as others who go there with the Venetian galleys, do much business with the Tripoline merchants. " 10 But he is also reporting that Tripoli "was ruined after its conquest by Christians. Nevertheless, they reinforced the castle with solid walls and important artillery." It is to presume that the town was rebuilt and the castle was transformed into a fortress with bastions. ${ }^{11}$

\subsubsection{Tripoli Under Ottoman Rule}

Since the beginning of the sixteenth century, Tripoli was the centre of power of the Turkish-Ottoman rulers, administrated by pashas and deys, followed by independent princes from the Karamanli family (1711-1835) and then again the Turkish and since 1911 by the Italian governors.

The first Ottoman period is characterised by a relative economic welfare due to important revenues coming from the trades and sea activities which were mainly connected to piracy. In particular, the al Saqizli rulers (1633-1672) were able to guarantee a period of relative peace and prosperity. It was at that time that the European states France and England signed commercial treaties with Tripoli to open up consulates inside the Medina. The French-Libyan relations were initiated during the 1630s under the reign of Mohamed al Saqizli. France sent a commercial representative to Tripoli, followed by the first French consul, who found his domicile in a building which still can be seen today. Until the outbreak of the Second World War, this house was home of the French consulate (42), when it moved outside of the old town. The British consulate (41), a house built in 1744 (Fig. 6.8), was situated nearby. The first British consulate was set up in Tripoli in 1658. The British consulate was used from the 
middle of the eighteenth century until 1940 and it used to be the starting point for geographical expeditions towards Africa. A hundred years later eight nations were represented in Tripoli including Denmark, Sweden, Holland (40), Tuscany, Spain (46) and the USA (37) (Fig. 6.5, 6.6, 6.7 and 6.8$).{ }^{12}$

\subsubsection{Becoming a Multiracial and Multireligious Hub of Commerce}

This first Ottoman period also evolves as an important period of construction, fortification and rehabilitation of the city. The map Tripoli at the dawn of the twentieth century shows the city as it was rebuilt and organised by the Ottomans at the dawn of the twentieth century. One can clearly recognise the cardo and the two principal decumani that show, along the strip parallel to the sea, a regular and wide

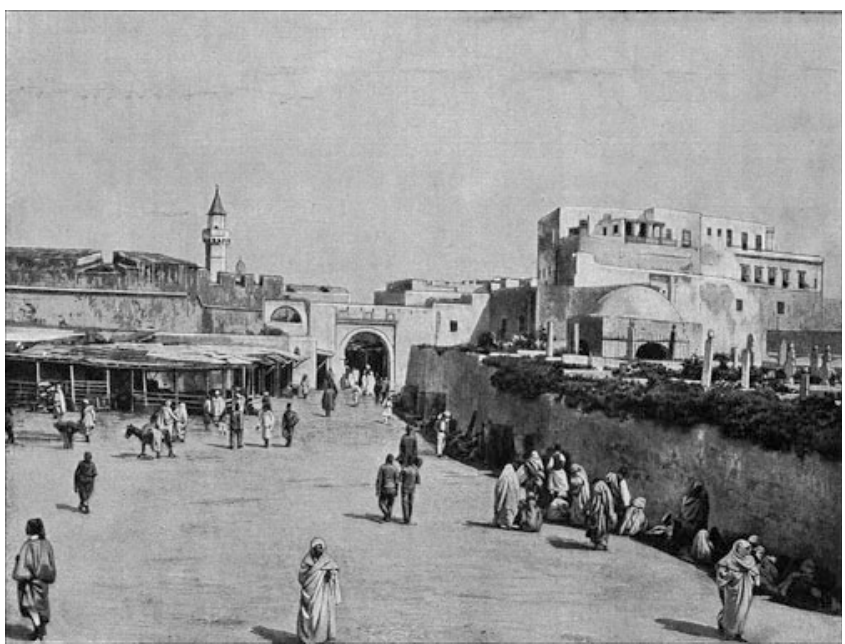

Fig. 6.5 View towards Babal Menshia. The menshia is the cultivated oasis which surrounded the walled city of Tripoli (Mathuisieulx 1912)

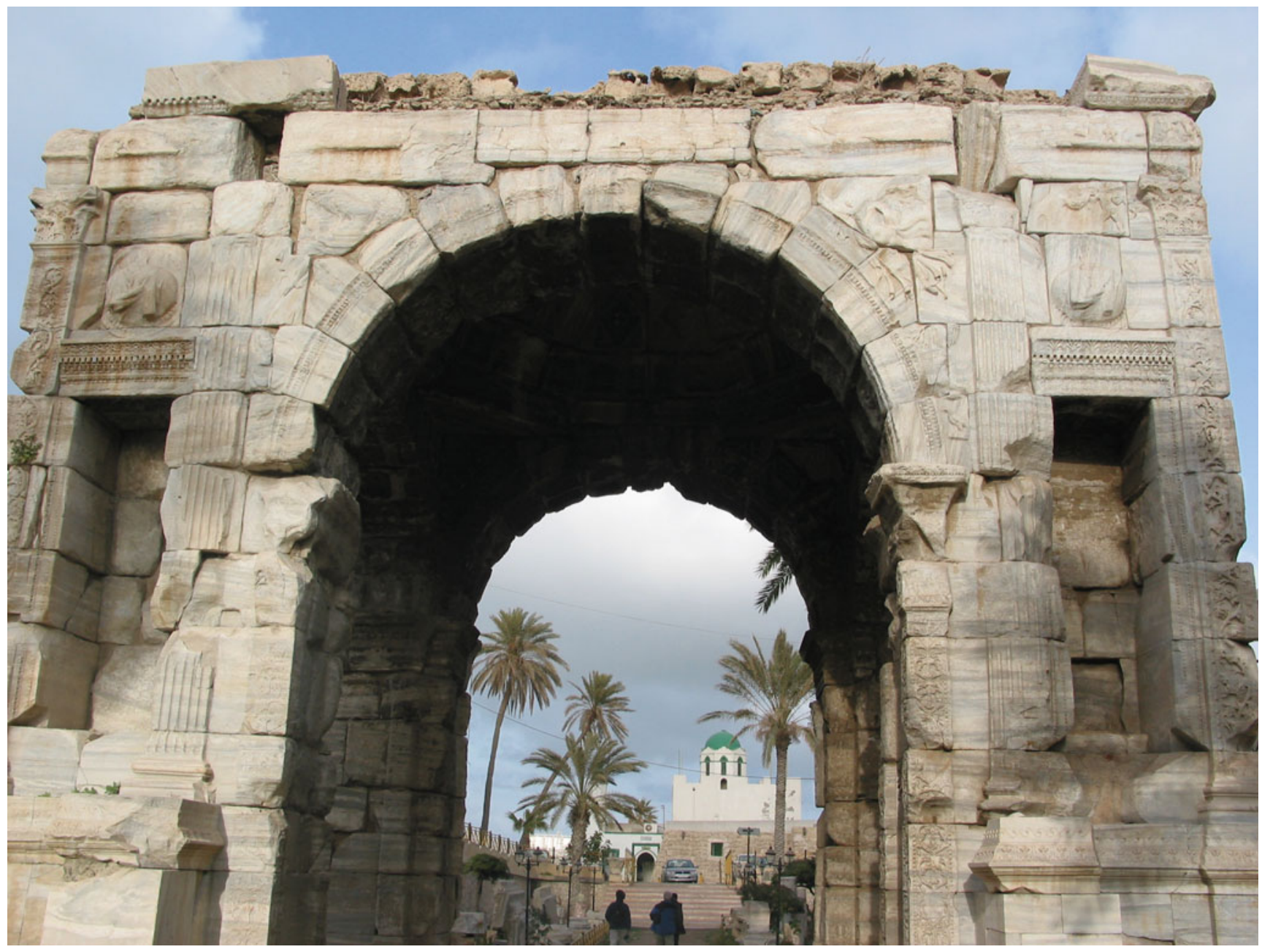

Fig. 6.6 Arch of Marcus Aurelius (22) 


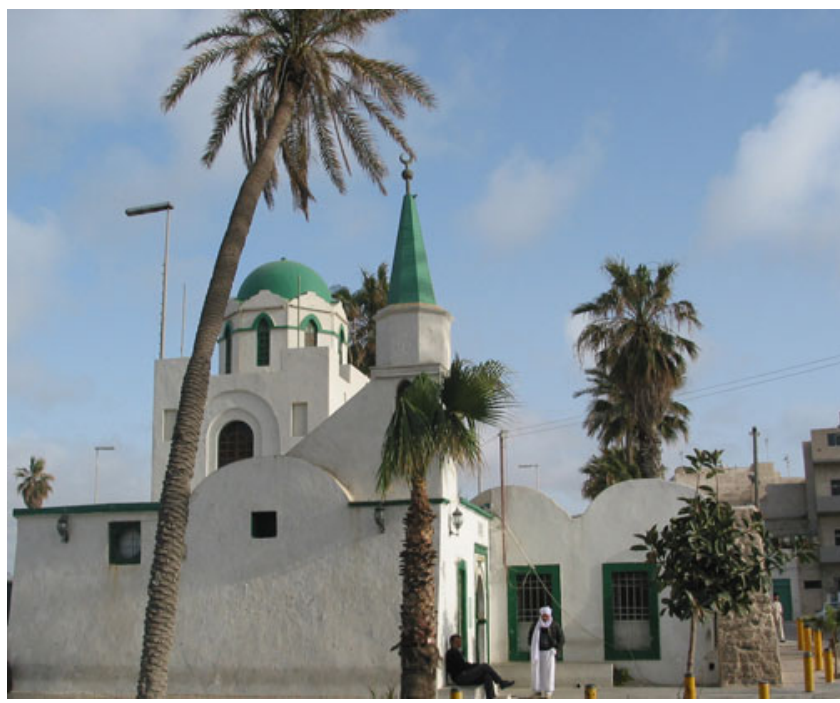

Fig. 6.7 A unique building can be found in the Bab al-Bahr area opposite the harbour. The mosque of Sidi Abdelwahab al Qyasi (87), originally served as a ribat, which is an Arabic expression for small fortifications that were built on the border of the Islamic sphere of influence

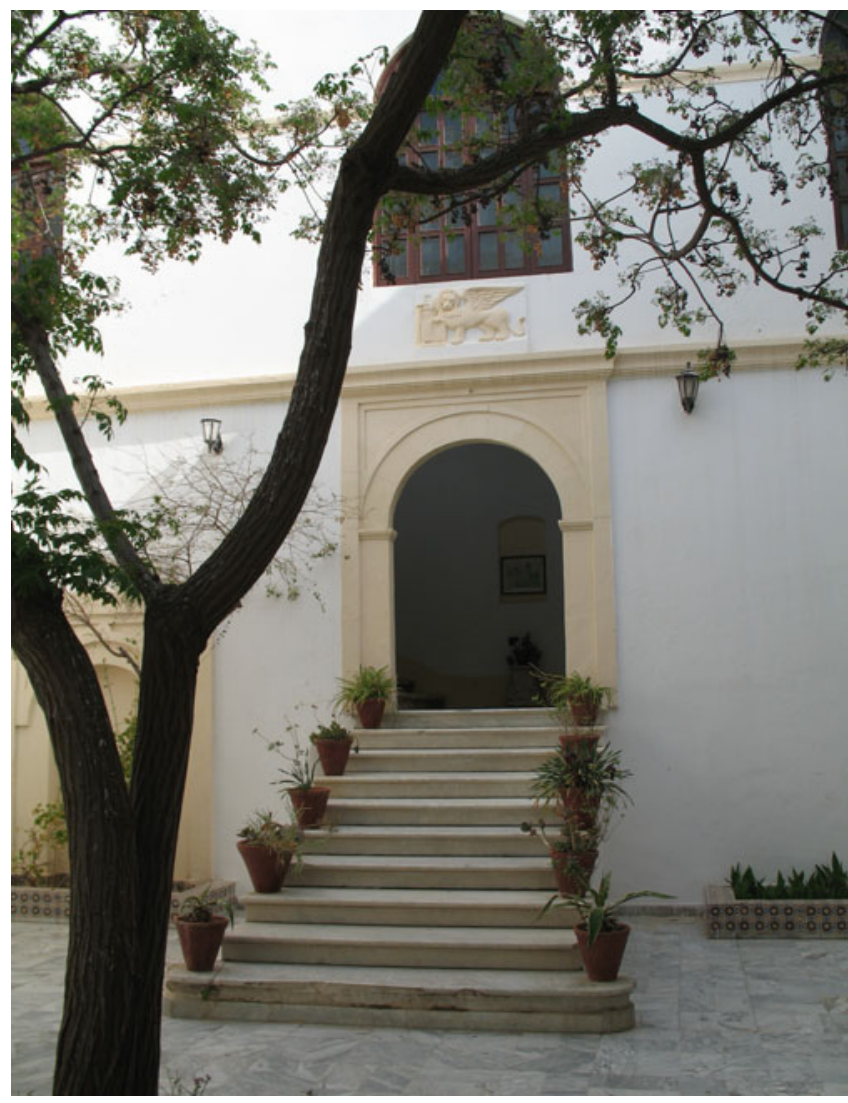

Fig. 6.8 The first British consulate (41) was set up in Tripoli in 1658 The French had established diplomatic relations 45 years earlier A hundred years later eight nations were represented, including Denmark, Sweden, the Netherlands, Spain and Tuscany grid of streets, recalling the ancient Roman plan. These are the main arteries of the Medina. The area along these arteries became the city's political, economic and religious hub. West of these arteries, the streets are becoming curvilinear to follow progressively the polygonal geometry of the walls which represents the Arabic-Islamic Medina. In the neighbourhood of the harbour, a specific quarter, characterised by the presence of the European consulates with their warehouses, began to take form.

New markets (aswaq, sg. suq) and fanadiq (sg. funduq, hotel and warehouse) were realised. ${ }^{13}$ With the construction of the Suq al Turk (13), the Suq al Qazdara (goldsmith's market) (9) and the Suq al Rbaa (10) the area became the densest commercial and artisan centre of the old town, integrating the already existing system of the aswaq. The Suq al Rbaa was built during the reign of Ahmed Pasaha al Saqizli (16491672). It represents the first market equipped with a roof in the city of Tripoli. The suq, which contains several columns of the Hafsid style, is still in existence today. Traditional costumes, hats, women's dresses and robes as well as men's traditional clothing are still sold here. Suq al Quaya and Suq al Kutub are part of al Rbaa old market. At Suq al Quaya, which is covered with a half-cylindrical vault, goods from Sudan such as ostrich feathers, leather and different kinds of dates were sold. ${ }^{14}$

Constantinople was far away, and therefore, a tight central control over Tripolitania was not possible. In Tripoli, a rule with strong local influence formed that was only nominally under the command of the Sultan and operated with the dreaded Corsair fleets in the Mediterranean. In 1711, the Turkish Pasha Ahmad Karamanli managed to become mainly independent, and he founded the dynasty of the Karamanli (1711-1835). The Karamanli family was of Turkish origin but related to the Arab-Berber people who formed the dominant group in Tripoli and its surroundings. Their advent with Ahmed Pasha al Karamanli (1711-1745) marked a long period of peace, which at least partially translated into a vivid urban life in Tripoli. In subsequent years, the multiracial and multireligious character of the Medina, which was inhabited by 14,000 people at that time, developed very fast. Due to the ever-present threat of piracy, new friendship agreements with European states were concluded. Regular consulates in some of the important houses of the Medina, located in the north-eastern urban area, were established. $^{15}$

The dynasty has also left its trace in terms of urban development. The mosque of Ahmed Karamanli (13) that was built between 1737 and 1738 is considered the largest and most beautiful mosque of the old town which also has a kuttab/madrasa (school). The richly ornamented mosque, which was described by the traveller Abulabbas Ahmed Mohammed al Fasi during his journey in 1796, is facing the Saraya al Hamra. It is situated at Suq al Mushir (8), that is the 
work of Rayab Pasha, Governor of Tripoli between 1906 and 1908. Two of the main commercial and artisan centres of the old town branch out of this suq, the already mentioned Suq al Qazdara (goldsmiths' market) (9) and the Suq al Rbaa (10). Adjacent to Suq al Rbaa, Ahmed Pasha al Karamanli founded the al Rbaa new market, Suq al Liffa (7). It was similar to the al Rbaa old market also dedicated to the selling of quilts, covers, coatings, carpets and costumes for women and men. ${ }^{16}$ Furthermore, the Karamanli house reflects the power and the living conditions of the former inhabitants. It was built in the second half of the eighteenth century. The Karamanli house (32) is situated at the four-column street (al Arbaa Arsat) 1, which was named as such due to the presence of four roman columns at the intersection of the four-columns street with the Suq al Harara (perfumers and spice dealers market, today the new goldsmiths' market) (6). During the reign of Yusuf al Karamanli, it was known as the "harem house". In the second Ottoman period of the nineteenth century, it was the domicile of the Tuscan consulate. The house, which is one of the most beautiful buildings of the old city, contains ornaments, columns, metal and woodwork and bears witness to the architectural development of Tripolitanian houses. ${ }^{17}$

The economic base of the Karamanli clan was mainly piracy which attracted the attention of the European powers. The French military campaign against Tripoli in 1728 ended with the almost complete destruction of the city. Nevertheless, only the French conquest of Algiers (1830) put an end to piracy also in Tripoli. ${ }^{18}$ The new political situation led to a decision of the Sultan of Constantinople to dismiss the last Karamanli Ali Pasha and govern Tripoli directly again. ${ }^{19}$

The various sources leave no doubt that Tripoli was among the most important ports in the Mediterranean for many centuries. It was also a central transhipment point for goods coming from the North African coast, the Middle East and Europe, whereas slaves were the most important commodity. One also gets the impression that in early modern times, there was no change to its trade habits, as the somewhat different insight into the city and its hustle and bustle shows, that Miss Tully offered to her readers. She was the sister of the British Consul in Tripoli, Richard Tully, who served there in the $1770 \mathrm{~s}$ and $1780 \mathrm{~s}$. In her letters, sent from Tripoli to an unknown correspondent in the years between 1783 and 1793, she recounts that in Tripoli's old town "they do not excel here in shops, the best of these being little better than booths, though their contents are sometimes invaluable, consisting of pearls, gold gems and precious drugs. There were two covered 'bazaars', one of which is very large, and built in four aisles, meeting in a cross. These aisles are fitted up with shops, built on each side of them, containing every sort of merchandize, and having a way in the middle for purchasers to walk in. Several parts of this place are nearly dark, and the powerful smell of musk makes it very unpleasant to pass through it. The other bazaar is much smaller, and has no shops in it. Thither only black men and women are brought for sale!" In her opinion, those slaves were brought and examined like cattle for sale. ${ }^{20}$ She mentions that Tripoli was in a dilapidated and in a "ruinous state".

Slaves taken to Tripoli were either bought for local use or were re-exported mostly in French ships to other parts of the Ottoman Empire like Constantinople, Greece, Crete and the Aegean. In the eighteenth century, and probably also in earlier centuries, the Mediterranean trade in black slaves had been nearly monopolised by French ships, largely because they had the greatest immunity from attack by Barbary corsairs. $^{21}$ In Tripoli itself, slaves from Sudan were conscripted into the Pasha's black guard; others did the hardest work (particularly in the quarries) alongside with Christian slaves who were mostly taken during corsair raids in the Mediterranean. Women and girls were bought as domestics and concubines. Profits from the slave trade enabled the Pasha's administration to finance the Mediterranean corsairs. 22 Miss Tully tells how those "unfortunate blacks" were frequently brought to the city. "They are carried to the bazaar, or marked house, where they are bought by the rich people of the place, who occasionally sell them immediately to merchants waiting to re-ship them to other parts." 23

Nearly 20 years later, in February 1819, the English traveller Lyon is out and about in Tripoli and reports about the lively bustle in the streets of the Medina and the surrounding markets: "There are two grand markets held weekly, one on the sands behind the town every Tuesday, and the other on Fridays, about four miles distance, amongst the gardens of the Meshea which form a stripe of about three or four miles in breadth, between the beach and the desert. In the town are Bazaars, which are open every day. These are streets, covered in overhead. The shops of merchants are ranged on each side, and are very small. Slaves and goods are carried about before the traders by auctioneers, who keep up a continual din, each calling the price last bidden. The Jews have a quarter of the town expressly to themselves, where they have their shops, and in which they are shut up every evening at sunset. (...) Several houses set apart for the reception of merchants and their goods are called Fondook [funduq], and answer to the description given of the Caravanserais of the East (Figs. 6.9, 6.10, 6.11, 6.12, 6.13, 6.14 and 6.15)."24

Lyon already indicated that the Jews inhabited their own quarter in the city, equipped with a synagogue and school. Actually, the Medina of Tripoli was divided into individual districts, whereas the individual quarters were separated from one another according to religious or tribal affiliation (see map: Population, Groups and Quarters). In this way, 


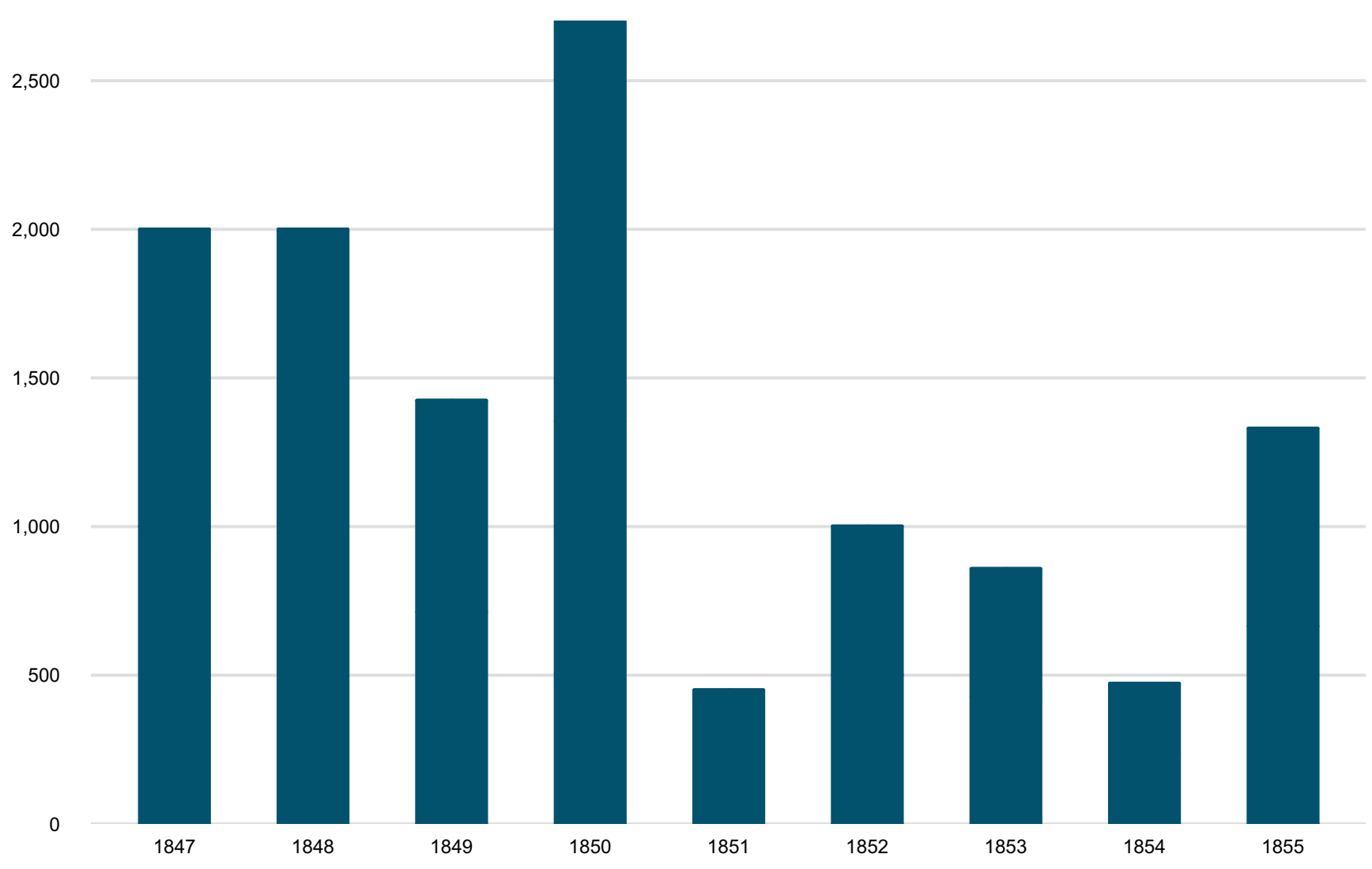

Fig. 6.9 Slave exports through Tripoli from 1847 to 1855 (see Lovejoy 1984)
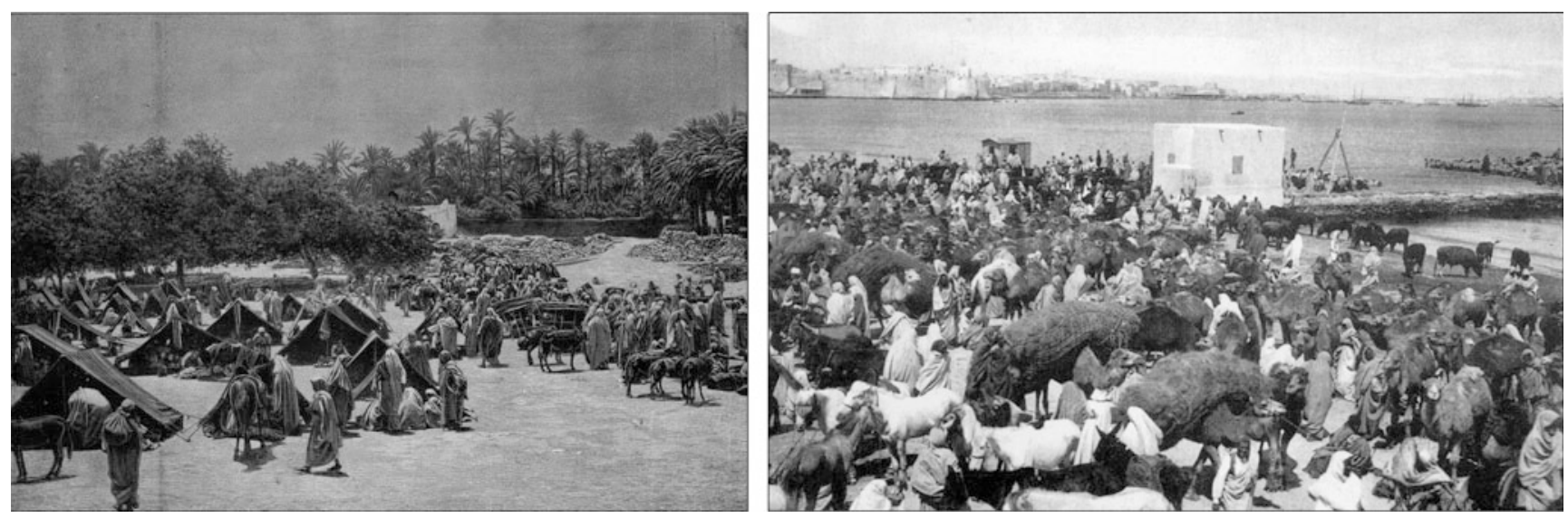

Fig. 6.10 The Suq al Juma (photograph on the left Mathuisieulx 1912) was held every Friday. It is one of the oldest markets in the suburb of Tripoli. Grains, vegetables, fruits and all kind of animals were sold here (photograph on the right, Laronde 1997)

Muslims, Jews and Christians were physically separated. According to a nineteenth-century almanac, Tripoli had six quarters that were called Homat Gharyan, Homat al Baladia, Kasha al Sogar, Bab al Bahr, Harat al Kabir and Harat al Saghira. These were separated by void spaces. The homas inhabited by the Jewish community were called harat (Harat as Saghira the smaller one and Harat al Kabir the larger one).
Homat Gharyan and Kasha al Sogar were mainly related to the caravan traffic. Homet al Baladia had a merchant character and was directly connected to the castle as the seat of the government. The particular character of a quarter was not only due to its different inhabitants, but also to its location. Bab al Bahr, where most of the Europeans lived, was located nearby the port and had purely marine features. ${ }^{25}$ 

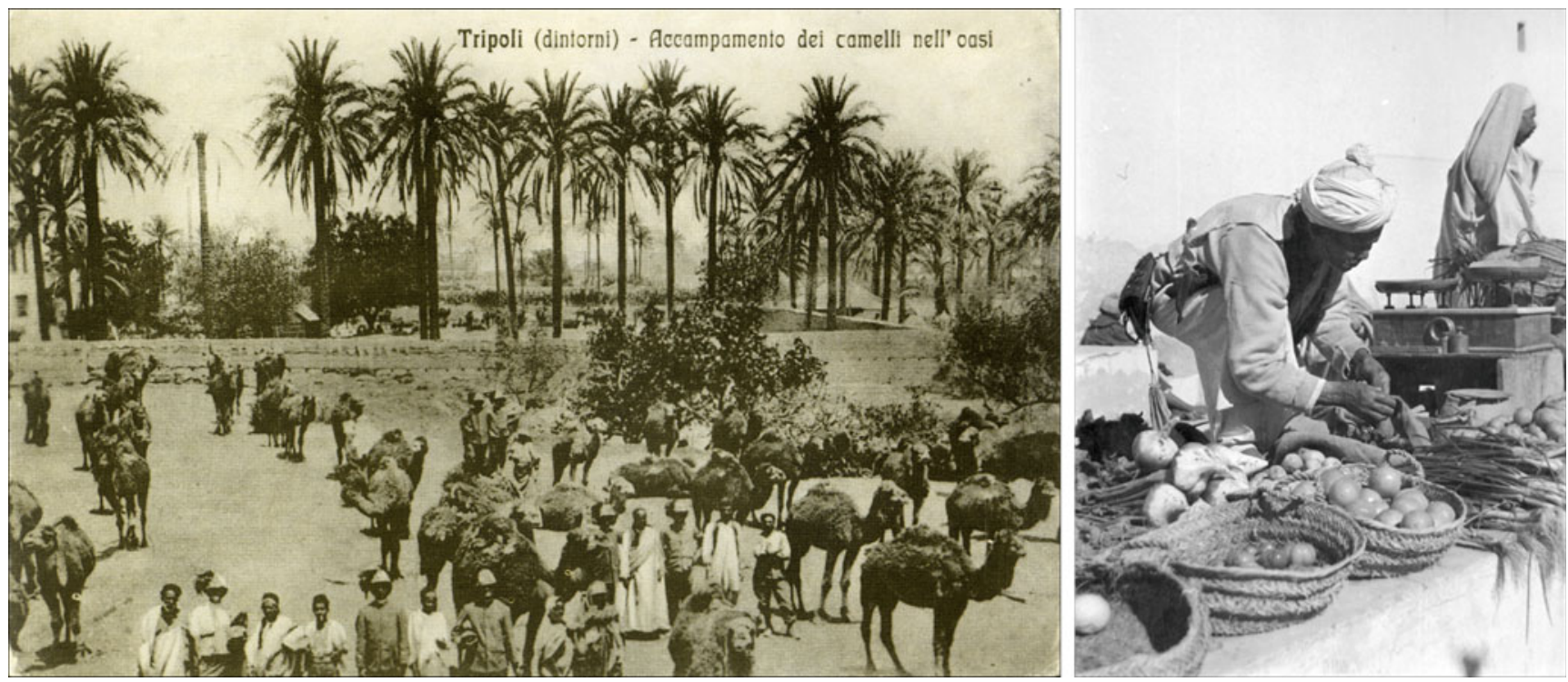

Fig. 6.11 A caravan arrives at the oasis of Tripoli (Laronde 1997) to sell their products at the various markets. The Suq al Thalata was held every Tuesday (11). It was divided into several sections: one for vegetables and fruits, one for meat, another for cotton, wool and ropes, while another section was for the sale of cattle, camels, goats and donkeys
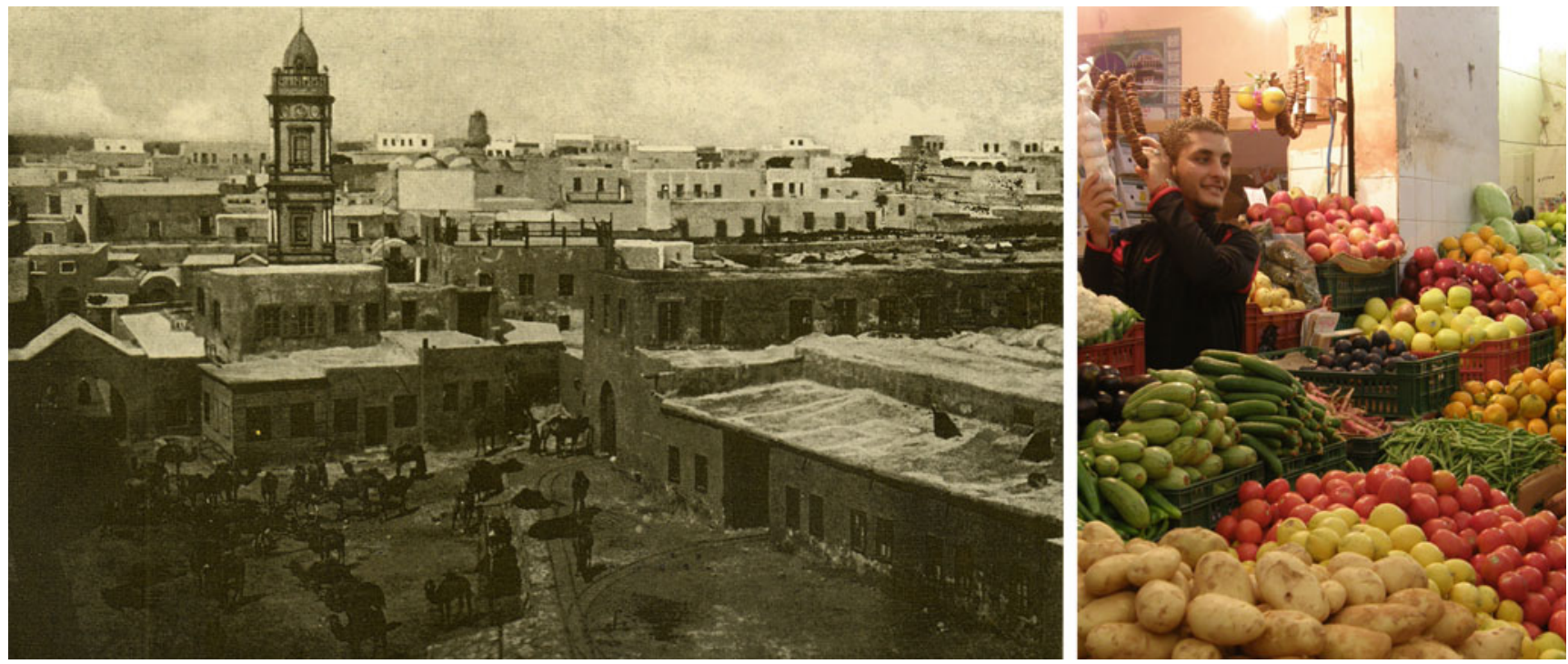

Fig. 6.12 A caravan arrived in the medina near the clock tower (24) (Laronde 1997). Today as then, the markets are busy with traders offering their fresh fare

For protection against the outside, a wall surrounded the Medina of Tripoli. In the end of the nineteenth century, there were four existing gates: Bab al Khandak (17) and Bab al Manshiya (18) were located on the southern side. According to Cowper, the Bab al Khandak was the chief one, being situated next to the castle. That adjoining it on the west was the Bab al Manshiya. He recalls that this one was double, with a small bazaar about sixty paces long between the inner and outer gates. This area was called Fum al Bab 2 ("the mouth of the gate"), and the chief article of sale was rope. ${ }^{26}$ Bab al Jadid (16, which was erected in 1865 during the second Ottoman period to replace the Bab al Zenata (19), in the western part of the wall and Bab al Bahr (14) was situated at the northern side of the town. Of the latter, today, only small remains at the mosque near the Arch of Marc Aurelius can be found. Bab al Zenata was closed between 1832 and 1835 during the civil war between the Karamanli dynasty and the Ottomans and could not be opened later on. During 

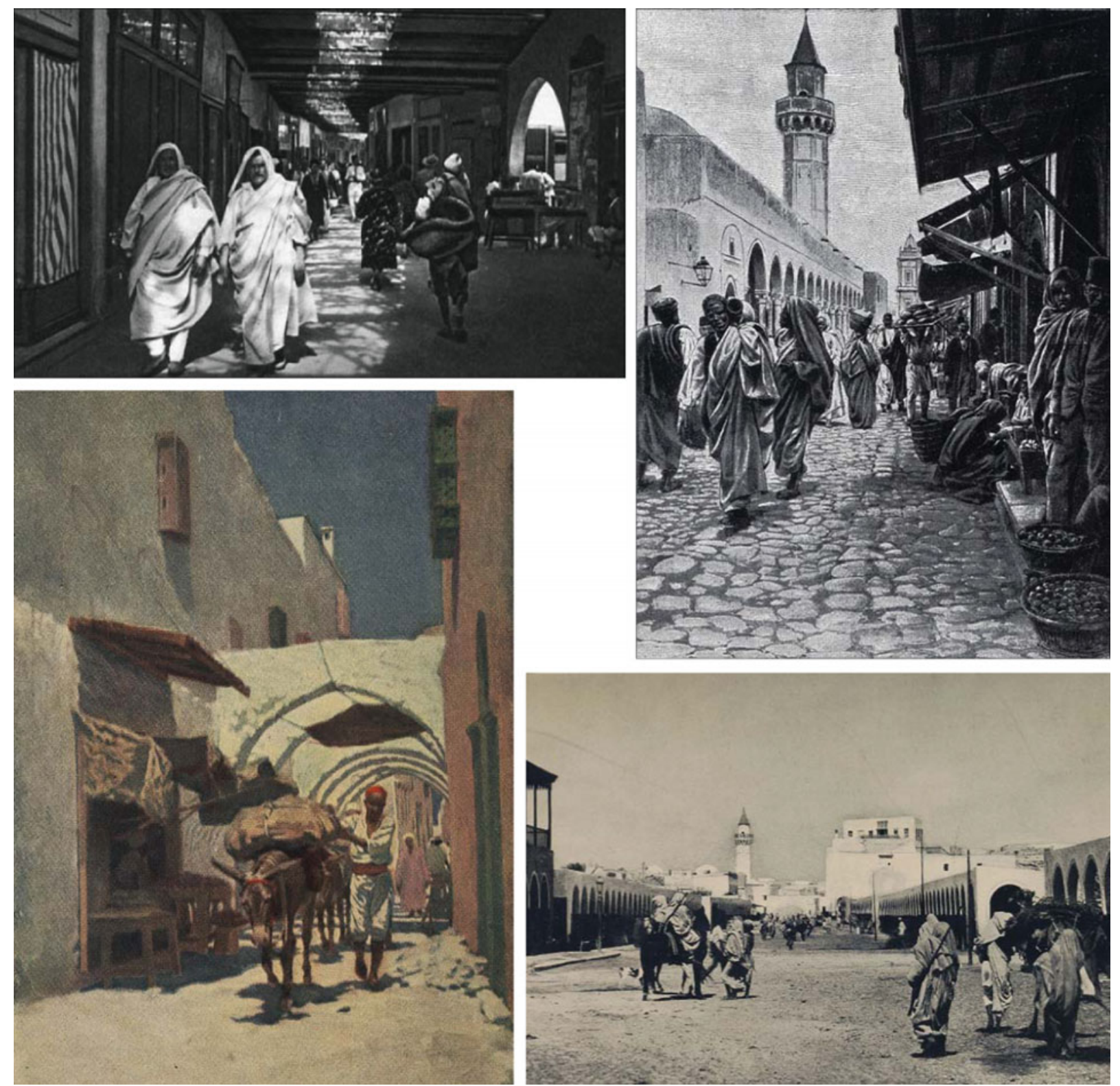

Fig. 6.13 In the streets of the medina in Tripoli: there were markets equipped with a roof to keep out the burning sun. It seems, that the markets were always crowded. In the background of the photograph on top right, one can notice an iconic monument in Tripoli, the Ottoman clock tower (24) (Mathuisieulx 1912). One of the most famous Tripoli`s byways is the so-called Arbaa Arsat (see photograph below on the left, Furlong 1909). The photograph below on the right shows the end of the great caravan route from the Sudan as it enters Tripoli (Furlong 1909, 198). The British tourist Edward Rae noted in 1877: "The bazaars occupy the southern end, under the wing of the castle. To reach them from the harbour gate, one traverses the European quarter (...). We entered the long blank white alleys of this neighbourhood, where flying buttresses overhead cast broad shadows whenever the sun is not in the zenith. We came, after a few turns, to the Turkish bazaar, the chief and broadest thoroughfare of the city. White walls on either side carried a rude roof, under which vines trailed, and through which the sunlight streamed. (...) Many of the shopfronts were painted blue. Here were the barbers and grocers, the silk and cotton merchants. (...) Jews in dark blue turbans. Moors in white turbans, Turks in the fez, Arabs in brown rough barracans of undyed wool, with bare brown legs, wandered to and from. (...) The barbers' shops were especially neat, having gaily coloured racks for razors and combs, and clean matted divans. They had, too, old hand-mirrors, inlaid with ivory and mother-of-pearl, and jars of leeches. In the cafes sat Moors, with clean turbans of straw-coloured silk and white stockings, while the attendants moved quietly about with brass trays and the little cups of scalding coffee. (...) Next came the blacksmiths' bazaar, the entrance to the Djemma ' $\mathrm{I}$ Basha, and the apothecaries' bazaar. We watched the shops of dates and milk, one of the most common resorts of the poorer classes, who found there their breakfast, and too often their dinner. (...) Honey stood in vast jars much of it comes from Candia esparto baskets stood full of raisins, beans, red pepper, and ground corn for kouskousou. In an oil shop stood prodigious jars of olive oil (...). Much of the oil comes from Zleitun and Imsellatah, among the Gharyan hills. Sellers of oil, having asses laden with skins, passed us. Near the long colonnade of Djemma 'l Basha is the flower market. Close by was a cafe, and on seats placed along the white steps, a crowd of soldiers in white linen were enjoying themselves. Facing the mosque were shops of ironmongers, with sheep-shears, flat horse-shoes, tin powder-horns, primitive shot-pans, and strings of cowrie shells brought from Tomboukto. Men were selling coarse quilted linen skullcaps; boys carrying baskets of mulberry leaves and blossom were crying out for proprietors of silkworms. In an apothecary's shop hung ostrich eggs; a little farther was a leather-worker."27 


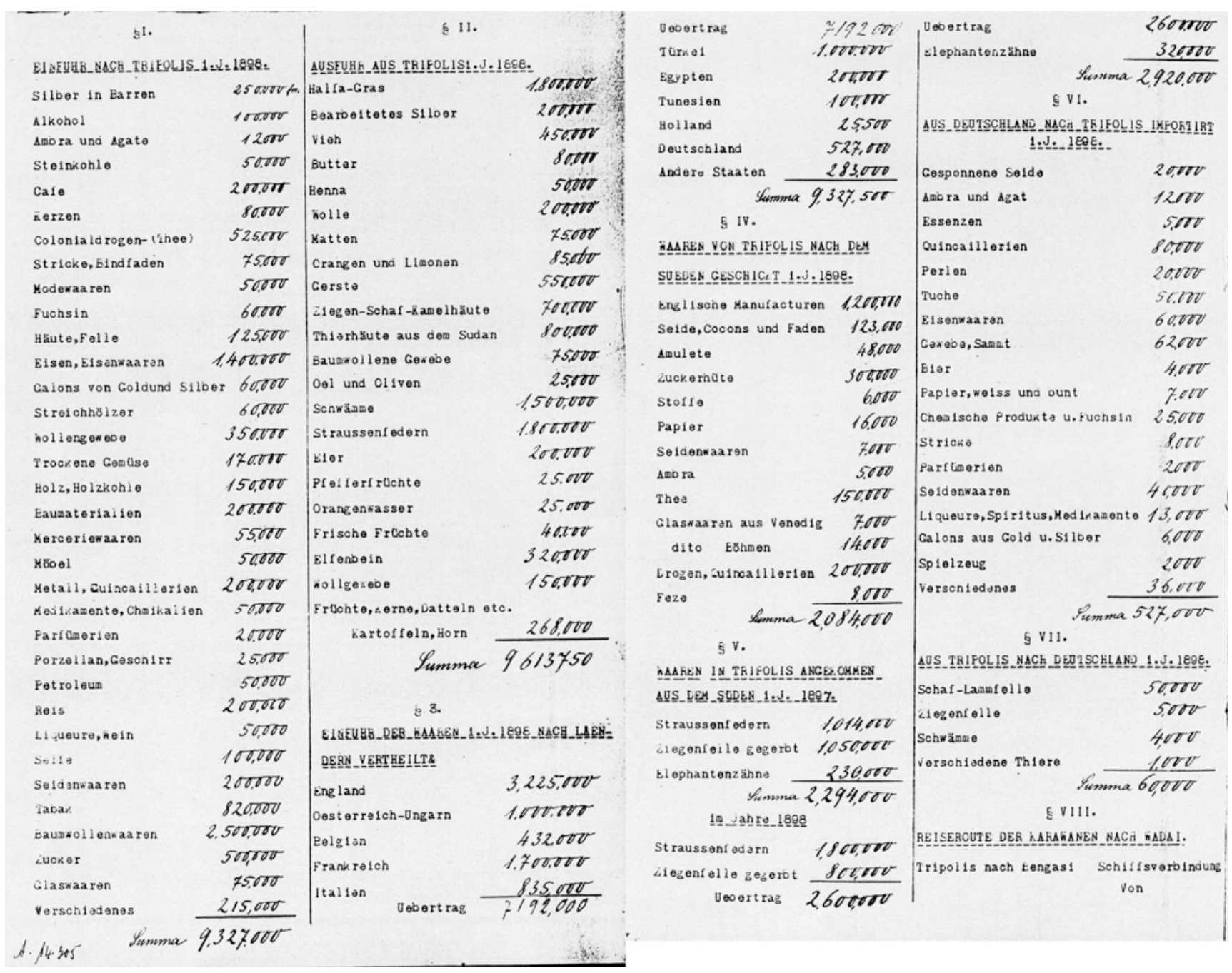

Fig. 6.14 Goods traded in Tripoli during the years 1897 and 1898 (German consular records)

the twentieth century, another three gates were built. On the 24 July 1908, the Bab al Hurriya (15) was inaugurated by the Turkish governor to remember the declaration of freedom. It was situated at the southern side of the wall. During the Italian time, Bab al Foulla, which means "hole in the wall", was built at the western side of the fortification. And in the 1990 s, Bab al Gaddafi was built opposite of the port in the $\mathrm{Bab}$ al Bahr area on the corner of the mosque of Darghut Pasha. $^{28}$

The individual districts with their narrow streets are typical for an oriental city. To the eye of the European viewer, it might at first be a maze of alleys. The so-called cul-de-sac layout of the individual quarters is a typical feature and at the same time characteristic for the physical appearance of the old city of Tripoli. Only a few main roads run through the Medina, often branching into narrow culs-de-sac. Numerous short streets then lead from the culs-de-sac into the interior of the residential blocks. Here, the desire of the residents for protection of privacy becomes apparent. The numerous markets (sg. suq), which Lyon or Miss Tully call "bazaar", a term that derives from Persian, characterise the cityscape of the Medina of Tripoli. They form the traditional commercial, industrial and financial centre of the city. Now as then, you will find retail, wholesale and foreign trade in the narrowest of spaces. According to Micara, the Medina of Tripoli is not just another replica of the Arab-Islamic city. The urban system was developed on a pre-existing Roman town and was built by different populations such as Arab-Berber, European and Jewish. He suggests speaking of Tripoli as a Mediterranean Medina. $^{29}$

Outside the Medina, there were two large markets which were held on different days. As Lyon reports, these markets were held each Tuesday and Friday. Both the Suq al Thalata (11) (Fig. 6.11) and the Suq al Juma (Fig. 6.10) are extremely persistent, not only in an eponymous function but also in 


\begin{tabular}{|c|c|c|c|c|c|c|c|}
\hline \multirow{2}{*}{\multicolumn{2}{|c|}{$\begin{array}{c}\S I . \\
\text { Imports to Tripoli }\end{array}$}} & \multicolumn{2}{|l|}{ § II. } & \multirow{3}{*}{$\begin{array}{l}\text { Amount carried forward } \\
\text { Turkey } \\
\text { Egypt }\end{array}$} & \multirow{2}{*}{$\begin{array}{r}7,192,000 \\
1,000,000 \\
200,000\end{array}$} & \multirow{3}{*}{\multicolumn{2}{|c|}{ 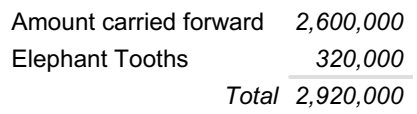 }} \\
\hline & & Exports from Tripoli & & & & & \\
\hline in $\mathbf{1 8 9 8}$ & $\begin{array}{r}\text { Francs } \\
250.000\end{array}$ & $\begin{array}{l}\text { in } 1898 \\
\text { Alfa Gras }\end{array}$ & $\begin{array}{r}\text { Francs } \\
1800000\end{array}$ & & $\begin{array}{l}200,000 \\
100,000\end{array}$ & & \\
\hline $\begin{array}{l}\text { Silver Bars } \\
\text { Alcohol }\end{array}$ & $\begin{array}{l}250,000 \\
100,000\end{array}$ & $\begin{array}{l}\text { Alfa Gras } \\
\text { Finished Silver }\end{array}$ & $\begin{array}{r}1,800,000 \\
200,000\end{array}$ & Holland & $\begin{array}{r}100,000 \\
25,500\end{array}$ & & \\
\hline Amber and Agate & 12,000 & Cattle & 450,000 & Germany & 527,000 & & \\
\hline Coal & 50,000 & Butter & 80,000 & Other Countries & 283,000 & & \\
\hline Coffee & 200,000 & Henna & 50,000 & Total & $9,327,500$ & & \\
\hline Candles & 80,000 & Wool & 200,000 & $\S \mathrm{IV}$. & & & \\
\hline Colonial Drugs-(Tea) & 525,000 & Mats & 75,000 & Goods Sent from Tripoli & & & \\
\hline Ropes, Strings & 75,000 & Oranges and Limes & 85,000 & send South in 1898 & Francs & & \\
\hline Millinery & 50,000 & Barley & 550,000 & English Manufactures & $1,200,000$ & & \\
\hline Fuchsin & 60,000 & Goat Sheep Camel Hides & 700,000 & Silk, Cocoons and Strings & 123,000 & & \\
\hline Hides, Skins & 125,000 & Animal Hides from Sudan & 800,000 & Amulets & 48,000 & & \\
\hline Iron, Ironworks & $1,400,000$ & Cotton Textiles & 75,000 & Sugar Loaves & 300,000 & & \\
\hline Gold and Silver Gallons & 60,000 & Oil and Olives & 25,000 & Fabrics & 6,000 & & \\
\hline Matches & 60,000 & Sponges & $1,500,000$ & Paper & 16,000 & & \\
\hline Wool Fabrics & 350,000 & Ostrich Feathers & $1,800,000$ & Silk Products & 7,000 & & \\
\hline Dried Vegetables & 170,000 & Eggs & 200,000 & Amber & 5,000 & & \\
\hline Wood, Charcoal & 150,000 & Peppper Fruits & 25,000 & Tea & 150,000 & & \\
\hline Building Materials & 200,000 & Peppper Fruits & 25,000 & Glassware from Venice & 7,000 & & \\
\hline Haberdashery Goods & 55,000 & Fresh Fruits & 40,000 & ditto Bohemia & 14,000 & & \\
\hline Furniture & 50,000 & Ivory & 320,000 & Drugs, Ironware & 200,000 & & \\
\hline Iron, Metal Goods & 200,000 & Woolen Fabrics & 150,000 & Fezzes & 8,000 & & \\
\hline Medicine, Chemicals & 50,000 & Fruits, Seeds, Dates etc. & & Total & $2,084,000$ & & \\
\hline Perfume & 20,000 & Potatoes, Horn & 268,000 & $\S \mathrm{V}$. & & & \\
\hline Porcelain, Tableware & 25,000 & Total & $9,613,750$ & Goods Arriving in Tripoli & & & \\
\hline Petroleum & 50,000 & & & from South in 1897 & Francs & & \\
\hline Rice & 200,000 & $\S 3$. & & Ostrich Feathers & $1,014,000$ & & \\
\hline Liqueurs, Wine & 50,000 & Import of Goods in 1898 & & Tanned Goat Skins & $1,050,000$ & & \\
\hline Soap & 100,000 & Ordered by Country & Francs & Elephant Tooths & 230,000 & & \\
\hline Silk Products & 200,000 & England & $3,255,000$ & Total & $2,294,000$ & & \\
\hline Tobacco & 820,000 & Austria-Hungary & $1,000,000$ & In 1898 & & & \\
\hline Cotton Products & $2,500,000$ & Belgium & 432,000 & Ostrich Feathers & $1,800,000$ & & \\
\hline Sugar & 500,000 & France & $1,700,000$ & Tanned Goat Skins & 800,000 & & \\
\hline Glassware & 75,000 & Italy & 835,000 & Amount carried forward & $2,600,000$ & & \\
\hline Miscellaneous & 215,000 & Amount carried forward & $7,192,000$ & & & & \\
\hline 1010 & 327,000 & & & & & & \\
\hline
\end{tabular}

Fig. 6.15 Translation of goods traded in Tripoli during the years 1897 and 1898 (German consular records)

their use. The Suq al Juma is one of the oldest markets in the suburb of Tripoli, about ten kilometres from the old town. It was named as such after the suq that was held every Friday in the oasis nearby. Grains, vegetables and fruits were sold here. The market has expanded to include the selling of all kinds of animals. ${ }^{30}$ While today there still is a popular market in the quarter of Suq al Juma, the Suq al Thalata (11), had to make way for an ambitious "Green Belt Project" in the year 2009 planned by the late al Kadhafi administration. In the past, the Suq al Thalata (11) was held every Tuesday. Tin sheet huts were built at night in the open air to become a busy market in next morning. The suq was divided into several sections: one for vegetables and fruits, one for meat, another for cotton, wool and ropes, while another section was for the sale of cattle, camels, goats and donkeys. The suq was moved to several places at various times throughout history. In the nineteenth century, it was held at the open space between the Saraya al hamra (Fig. 6.4) and the municipal gardens, then it was moved to the area between Bab al Jadid and al Maarri Street, and later, it was moved to the site Bab al Azizia. ${ }^{31}$ This market stretched over an area of about four hectares until the end of 2009. It primarily housed retail shops of various industries such as electronics, toys or accessories. In the course of the implementation of the green belt, the local dealers were resettled, a fact which has led to fierce debates in public. Starting point for these measures was a decision of the government to establish an urban green belt. The dealers affected by the resettlement were compensated with the provision of areas on the outskirts, which, however, could not satisfy a large number of the affected traders. The resistance was sparked mainly at the new location which is far outside of the city centre. 


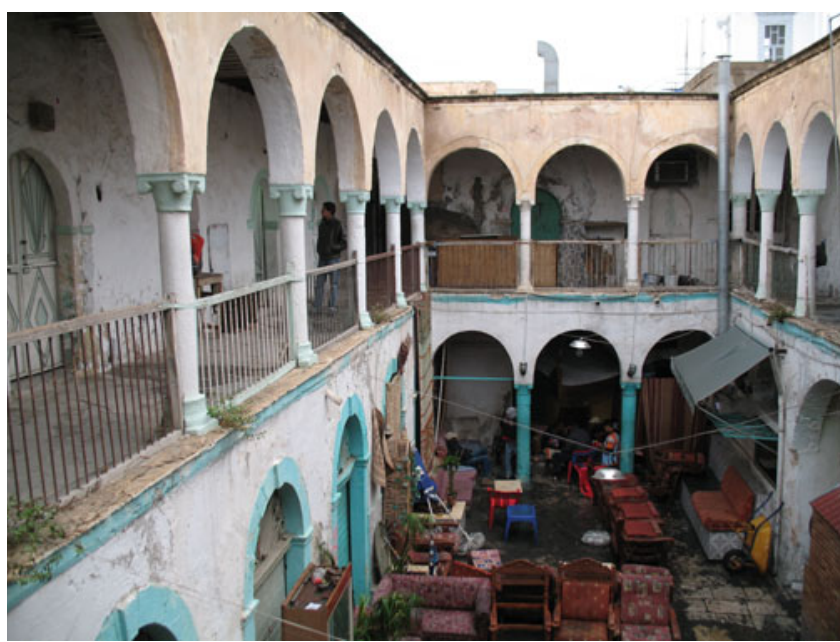

Fig. 6.16 $\mathrm{Al} \mathrm{Zahr}$ funduq (99) is situated at Suq al Mushir

Lyon, however, also describes another important "institution" of Tripoli, the funduq. The funduq, the equivalent of which is the caravansary in the Middle East, not only is in structural terms one of the most striking building types in the Medina in Tripoli, but can also be found in a great number there. According to records, there were approximately 35 fanadiq in the Medina. Twenty-one of them are known by name. They were located along the big markets, west of the cardo and near the seaside. al Zahr funduq (59) (Fig. 6.16) situated at Suq al Mushir (8) is considered to be one of the best examples. It is most likely that it was built during the reign of Yusuf al Karamanli by Mustafa Gurgi, the brother-in-law of the pasha. The place was named al Zahr, which in Arabic means orange flower, because this kind of flower and other flowers and essences were stored and sold in the open courtyard. Fragrant products such as orange flowers, henna and volatile oils were also distilled and then shipped to Turkey. There is a large wooden door, known as the Bukhukha door, leading towards the entrance which today accommodates a café. The entrance also has a circular vault with a prominent architectural ornament at the top. As usual, the funduq consists of two floors. To the left is a staircase leading to the upper riwaq, which is an arcade or portico open on at least one side. It has four galleries with 28 rooms opening onto them. In the past, the rooms on the upper floor were used as accommodation facilities for merchants or other guests. The rooms in the lower riwaq served as storage rooms of the caravans. Today, there are numerous shops. Many of these facilities have a persistent structure by retaining their type of use, and until the end of the regime of Gaddafi, they served as hotels to accommodate mainly tourists and business travellers (Fig. 6.17). ${ }^{32}$

In 1835, the Turkish sultan felt disposed to interfere because of inner disruptions in Tripoli and put an end to the rule of the Karamanli family. As a result, Tripoli was

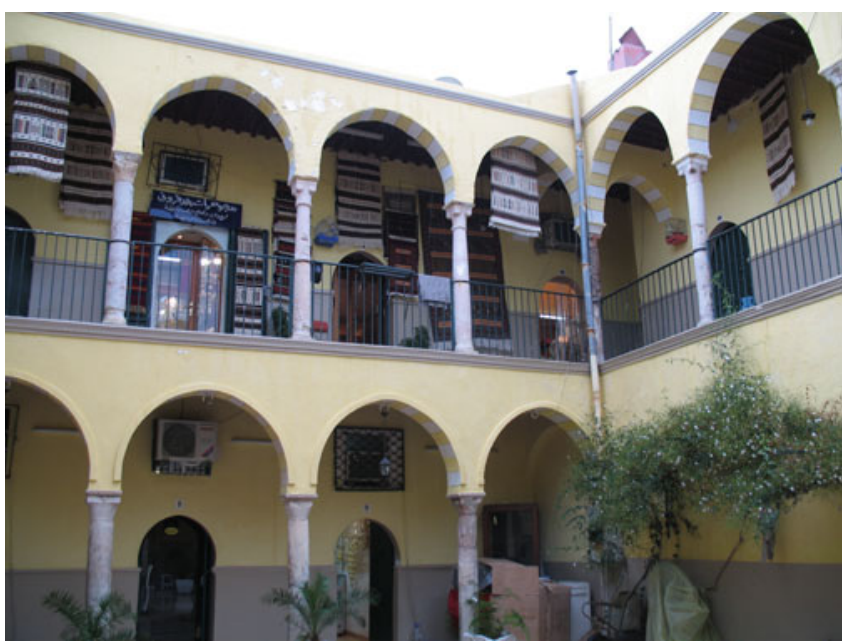

Fig. 6.17 A funduq is a characteristic phenomenon for the old town of Tripoli. Miss Tully, the sister of the British Consul in Tripoli, Richard Tully, gives a vivid insight into everyday life in a funduq in her letter from 9 September 1783: "This building is very huge, with a square area in which is a well and a gebia, or marble reservoir for water, for the convenience of the Moors to wash in before prayers and meals. Round the area is a number of small rooms, each for the goods or merchandize of the person or persona who may sleep in the apartments over it. The camels, horses, and mules of the travellers are ranged round the yard. When a stranger arrives, a Moor dusts the floor of an empty room, and spreading a mat, which is all the furniture allowed, leaves the guest in quiet possession of it. Those who can afford it, are expected, on quitting it, to leave a small gratuity to the porter, and none can get out or into the fenduke till the adan, or dawn of day, when a Moor unlocks the gates." (Tully 2009, 27-28)

incorporated into the Ottoman Empire as vilayet. However, the splendour of the bygone days seemed lost. According to Robert Greenhows' "Sketches of the history and present condition of Tripoli", the town was run down at that time. "Tripoli, the other and least important of the States of Barbary (he compares it to Algiers and Tunis), had until lately pursued a course similar to that of Tunis, and its condition was highly prosperous; (...)." But now, "there is but little appearance of wealth in Tripoli; the Moorish population amounting to about fourteen thousand are in general very poor, the trade being almost exclusively in the hand of the Jews, whose number is about two thousand. The palace contains some apartments possessing a certain degree of grandeur and furnished in a costly manner principally with French articles; in the town there are a few good stone buildings, with courts and arcades in the Italian style; these are however chiefly occupied by the foreign Consuls and merchants, the greater part of the inhabitants dwelling in mere hovels of mud but one story high. The roofs of the houses are all flat, and great care is taken to have the rain conveyed from them into cisterns, as there is not a well or spring of fresh water in the place. (...) the immediate environs of Tripoli are desert; about two or three miles to the eastward is a rich and highly cultivated plain called the 
Messeah where the Foreign Consuls and the wealthy inhabitants of the town have their villas". 33

The ruling powers in Tripoli were the first to desist from piratical cruises during the Barbary wars. Dissensions in the family of the sovereign had also led to numerous revolts in different regions, repressed more or less successfully. In view of the French pressure that was being exerted on the Karamanlis and on account of the presence of the French in Algeria, the Ottomans decided to display the suzerainty of the Sultan over Tripolitania. ${ }^{34}$

In the course of the nineteenth century, the town has apparently recovered. According to Rohlfs, "the streets of Tripoli are wide and clean (of course always in comparison with other Muslim cities) and some of them have been paved lately and provided with lanterns". 35 He further states that Tripoli continued to expand its trade every year. During the years of 1868 , 1869 and 1870, an annual average of 427 ships entered the port and 414 ships left it. In 1875, the number of the outgoing and incoming ships had more than doubled, according to Rohlfs. ${ }^{36}$ According to an almanac from 1882 to $1883,25,000$ inhabitants, among which were 4000 Jewish and 3000 foreigners, lived in the capital of the vilayet of Tripoli. This is an indication that trade in the late nineteenth century was still flourishing; however, it entered a state of stagnation with the progression of the Ottoman rule. Economic life stagnated towards the end of the Ottoman era which affected the frequenting of the port. At the beginning of the twentieth century, the German geographer Banse noticed an "empty port": "Until 1911 three steamers at once were a great event." 37 He describes Tripoli at the beginning of the twentieth century as an economically depressed city.

There are many reasons for this stagnation: the fall of the Ottoman Empire had already advanced, and the caravan trade stagnated, as one of the most important acquisitions from the south, slaves, could no longer be traded. Until well into the nineteenth century, slaves were an important commodity despite the signing of an anti-slavery agreement on the part of the Ottoman Empire. Until the 1850s, the Ottoman authorities regarded the slave trade as an open, acceptable and legal business, and appropriate taxes were levied and paid on it. Furthermore, political events, both outside of Africa and inside the caravan trade, had a strong influence and triggered the rise and fall of the terminal port cities. Many researchers make it clear that Tripoli was almost entirely dependent on the trade with the sub-Saharan hinterland in the interior of Africa. Around the turn of the century, a lively caravan trade was part of the foundations of life of many North African port cities. The situation of Tripoli rapidly deteriorated towards the end of the nineteenth century as the French annexed more and more territories between Niger and the Tibesti mountain range to their colonial empire. Since then, a border separates Tripoli from its "hinterland", a state that was not to change by the Italian seizure of power. ${ }^{38}$
Unlike European cities in the nineteenth century, cities in the Arabic-Islamic area were not exposed to the radical growth and conversion process. As in Tripoli, in many cases, the medieval city fortifications had maintained their character as physical city limits. Only with the annexation of Libya by the Italians, the city experienced a period of rapid urban growth. Since about 1880 , the city started to expand slowly across the surrounding walls to the south-east. At the end of the Ottoman rule, the expansion of the city concentrated along the main arterial roads that extend in a radial direction to the south and south-east starting from the market place in front of the old town in the south-east. Previously, only a few hotels and stalls were found outside the old city walls. At first, barracks were built. As a result, many officers left the old city. Rather quickly the new city of Tripoli established itself around the turn of the century (see map: Core area of Tripoli Development of settlement area between 1909 and 2002).

\subsubsection{Tripoli on the Eve of the Italian Invasion}

Gottlob Adolf Krause, a German Africanist who travelled to Tripoli for the first time back in 1868 , took up residence in the city again from 1907 to 1912 and thereby bore witness to the Italian preparations for colonial expansion. He chronicled developments including the numerous business connections established at this time between Tripoli and Italy as well as other European nations. Here, particular mention must be made of a steam-driven mill owned by the Banco di Roma, which was supplied with grain from Italy and generated profits through the sale of flour, an esparto grass press which also belonged to the Banco di Roma, and a factory for the production of ice on which the Italian operating company had an apparent monopoly. ${ }^{39}$

As well as describing these economic activities and the associated geopolitical interests of the European powers, Krause also devoted himself to documenting the day-to-day characteristics of life in Tripoli. He gave detailed descriptions of the happenings and the goods available at the various markets, in particular the Suq al Thalata, which was held every Tuesday at the entrance to the city. According to Krause, the market had "gained a certain renown thanks to its vibrant, oriental image" 40 and the authentic Middle Eastern way of life shows there regularly drew French visitors arriving on the steamer from Tunisia.

A crucial and central concern for Tripoli's residents in addition to trade and providing the growing population with all manner of goods was the supply of water. As was the case in the entire Mediterranean region, it was necessary to establish water supply systems in order to survive the dry summer months. These systems traditionally use cisterns to store precipitation collected during the winter. An alternative 


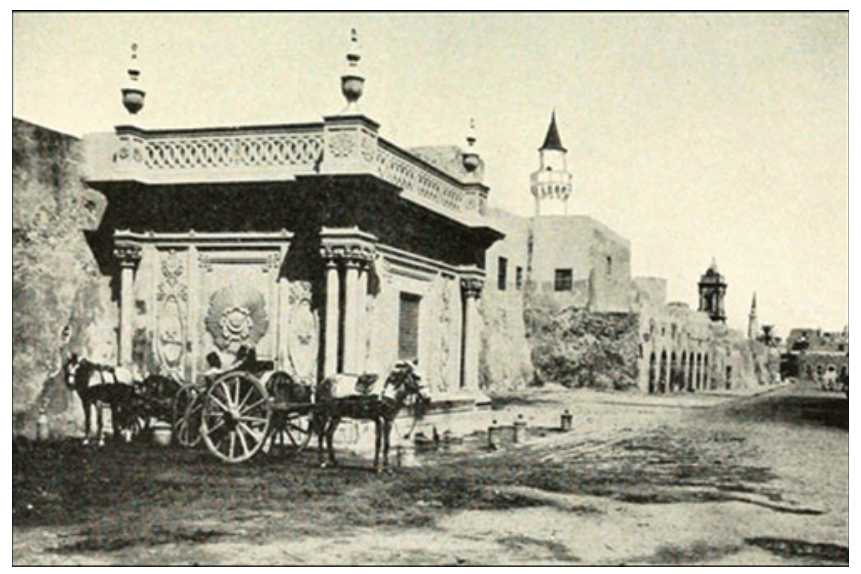

Fig. 6.18 Pashas fountain fed by the $\mathrm{Bir} \mathrm{Bu}$ Meliana at the south-eastern entrance to the Medina at Bab al Khandak (17)

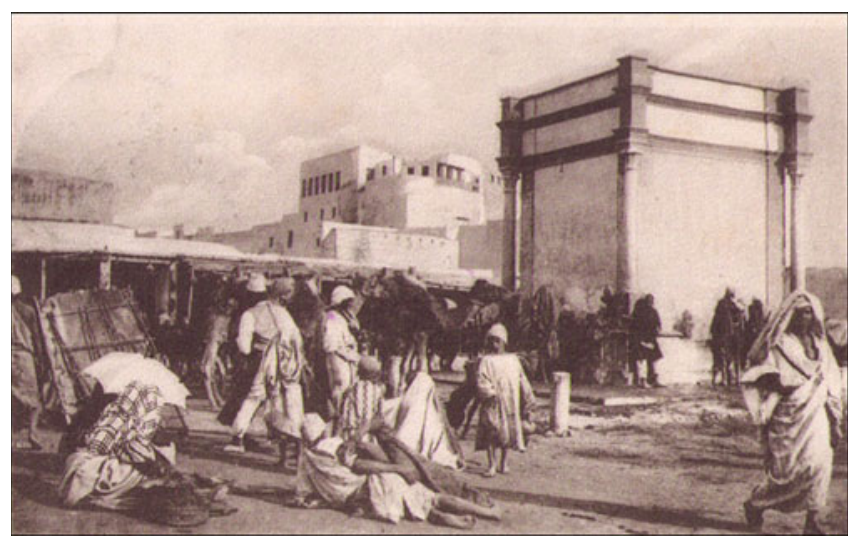

Fig. 6.19 Suq al Cobza (bread market) (4) with a fountain in 1916

approach is the construction of wells to tap groundwater from deeper underground. However, this proved difficult in the immediate vicinity of Tripoli as salt water from the Mediterranean entered the water-bearing strata, rendering the water undrinkable. To guarantee the water supply in spite of this, according to Krause, the Turks installed wells at three locations in the city which drew water from a source via a small water conduit. The source is located around two and a half kilometres south-southwest of the city and is known as Bir Bu Miliana (Fig. 6.18), which literally means "father of abundance well," a reference to its inexhaustible water reserves. ${ }^{41}$ The well was reached by following the street which ran due south from the bread market (4) (Fig. 6.19). After crossing the "new town" built during the Ottoman period, the path then arrived at the gardens full of date palms and olive trees. The well itself was situated at the southern edge of these gardens, which marked the relatively abrupt transition to the adjacent barren semi-desert.

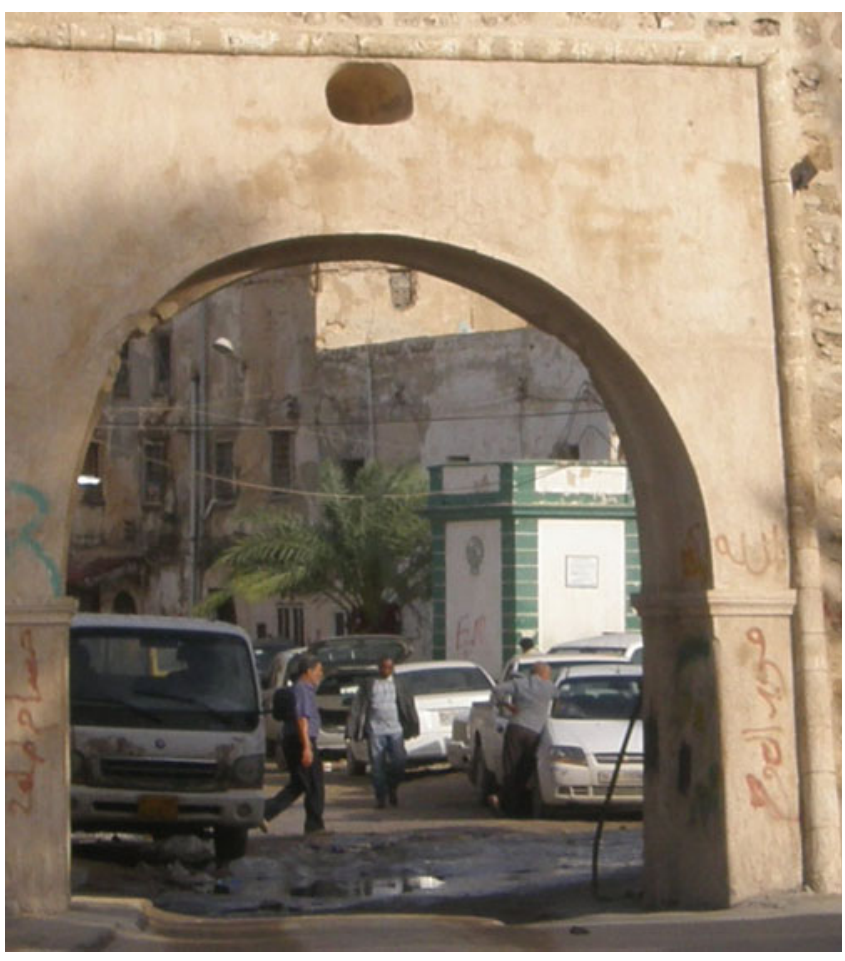

Fig. 6.20 Fountain at Bab al Jadid (16) is still visible today

According to Krause, the water channelled from there into the city could be collected at three "schisms" or distribution points by anyone who wanted it, though he adds that in reality the water was "transported to customers in the city and suburbs by professional or casual water vendors". ${ }^{42}$ It remains unclear whether people had water brought to them out of convenience or whether a payment was required which was collected by the water vendors.

These public "water filling stations" were all located on the edge of the medina. Two of them were built in close proximity to each other. The fountain known as "Pascha's Fountain" was situated directly at the entrance to the medina at the Bab al Khandak (17), and the other in the middle of the bread market. The third fountain was located inside the medina, directly at the city wall at the Bab al Jadid (16) (Fig. 6.20). The Bir Bu Miliana well supplied a fourth facility built by the Turks in the middle of the Suq al Thalata (11), which ran along the coast to the east and south-east of the medina and joined the Pasha's Public Gardens at its eastern end (22). Krause reported on this as "a new creation by the Turks" (Fig. 6.21). ${ }^{43}$

In 1911, Tripolitania was annexed by Italy. The seizure was carried out with military means as the Italians encountered heavy resistance not only by Turkish troops but also by the Libyan tribes. Only in 1934, the Italian colony Libya was set up from the conquered territory, and in the years that 


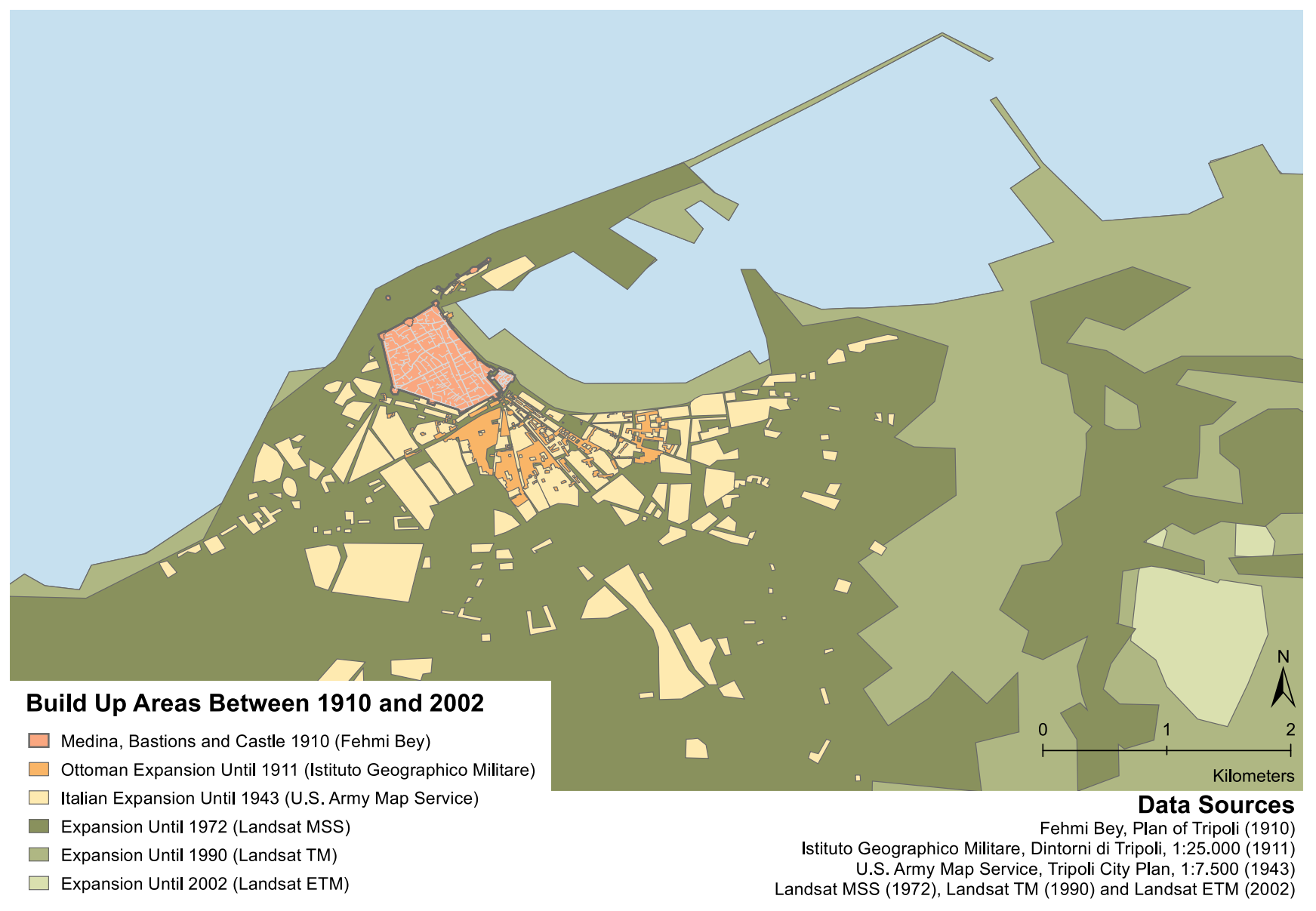

Fig. 6.21 Map: Core area of Tripoli-Development of settlement area between 1909 and 2002: like most cities of the Arab region, Tripoli did not undergo that much growth and transformation during the nineteenth century as the European cities did. However, it provides a good example of modern urban development taking place immediately adjacent to the historic nucleus. The origin of the new town dates back to 1880 when the Ottoman administration started developing a number of new technical and residential districts extra muros across the south-east. The expansion of the city concentrated along the main arterial roads that started in the centre of the marketplace in the south-east, opposite to the medina and extending to the south and south-east. With the annexation of Libya by the Italians in 1911, the period of rapid growth for the city began, which clearly reflected contemporary European town-planning influences

followed, 100,000 colonists were settled there. Apart from the existing settlement, a planned European new city started to grow.

\subsubsection{Roman Legacy Versus Indigenous Traditions}

With the annexation of Libya by the Italians in 1911, the period of rapid growth for the city began. This expansion clearly reflected contemporary European town-planning influences - although the colonial planners tried to use an architectural language that offered a Western conception of Eastern architecture. ${ }^{44}$ In doing so, urban architecture was shifted from the modernist appropriation of the early 1930s, in which the indigenous culture is fused with modern aesthetic sensibility, to a historicist one in the latter part of the decade, when the indigenous is re-enacted as a racially encoded project of historic preservation. The new town limited the old town of Tripoli soon to the role of a historical core. Urban growth was concentrated along the development axes. Being influenced by the Ottoman period, it followed the main arterial roads to the south-east. Further development took place subsequently in concentric rings around the current centre. Moreover, the Italian authority began remodelling some parts of the old town with the demolition of parts of the walls in order to construct a modern port with the material. ${ }^{45}$ But it was not long before the value of preserving the fabric of the Medina was recognised when tourism became a major key aspect in the development of the colony. Among the first projects to be undertaken was the restoration of the wall of the old city in 1923. But the decision of what would be preserved and what not was solely in the hands of the Italian authority, viz. the building 


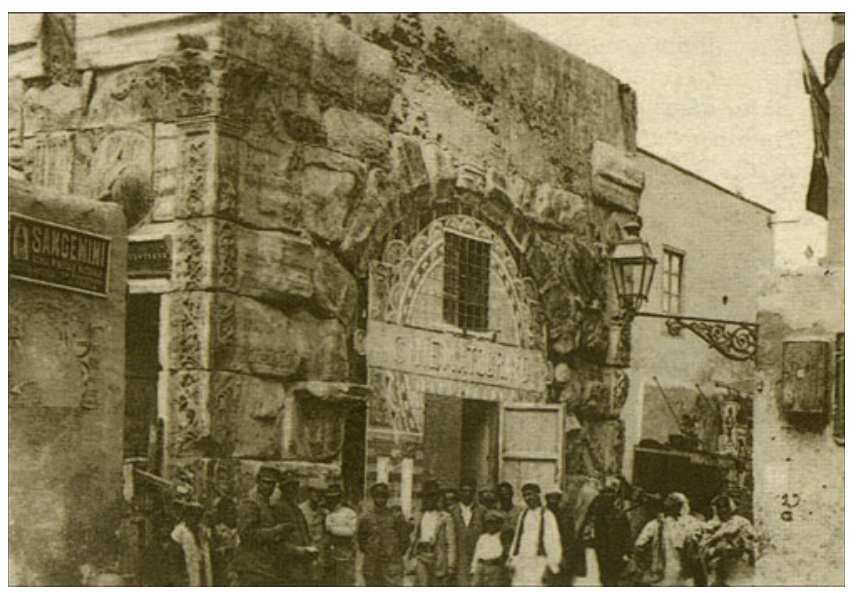

Fig. 6.22 At the beginning of the Italian rule there was a cinema in the arch (27) (Laronde 1997)

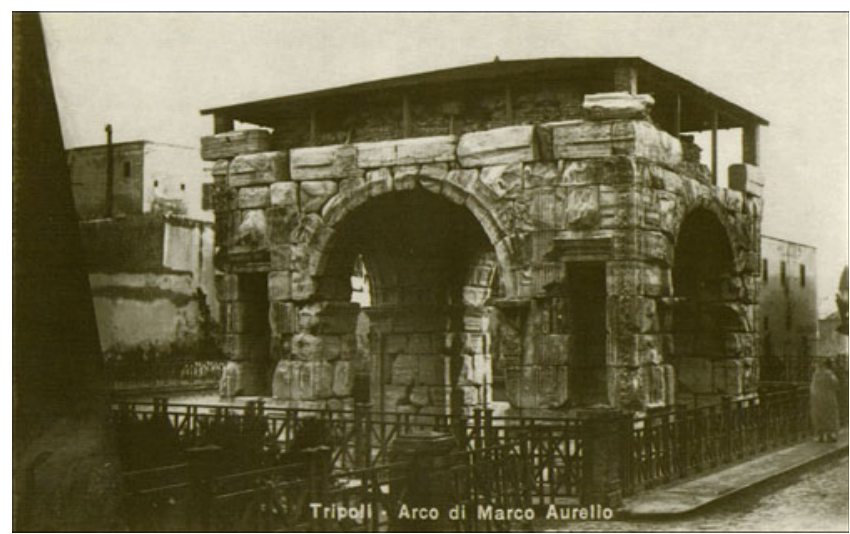

Fig. 6.23 Arch of Marc Aurel in 1937 (27) (Laronde 1997)

commission, which on the one hand used modern principles of hygiene and urban order and, on the other hand, chose to value one history - of course, the Roman one - over the other. ${ }^{46}$ The conflict between Libya's Roman legacy and its indigenous traditions was resolved in a manner that was entirely consistent with the values that informed Fascist planning in Rome. Monuments were "liberated" from centuries of anonymous built fabric. ${ }^{47}$ The restructuring of the area around the Arch of Marcus Aurelius (27) (Figs. 6.22, 6.23 and 6.24) actually created considerable discontinuity in the adjacent fabric, requiring the demolition and restructuring of substantial portions of three of the city's most significant eighteenth-century fanadiq (hotels). ${ }^{48}$ From a historic-cultural point of view, the dealing with the triumphal arch clearly illustrates the interpretation sovereignty and patterns of this most obvious relic of ancient Oea. During his first visit to the city in 1846, Heinrich Barth, a German historian, noticed that "this arc is not without interest, however its four arched openings, [...], are now bricked up

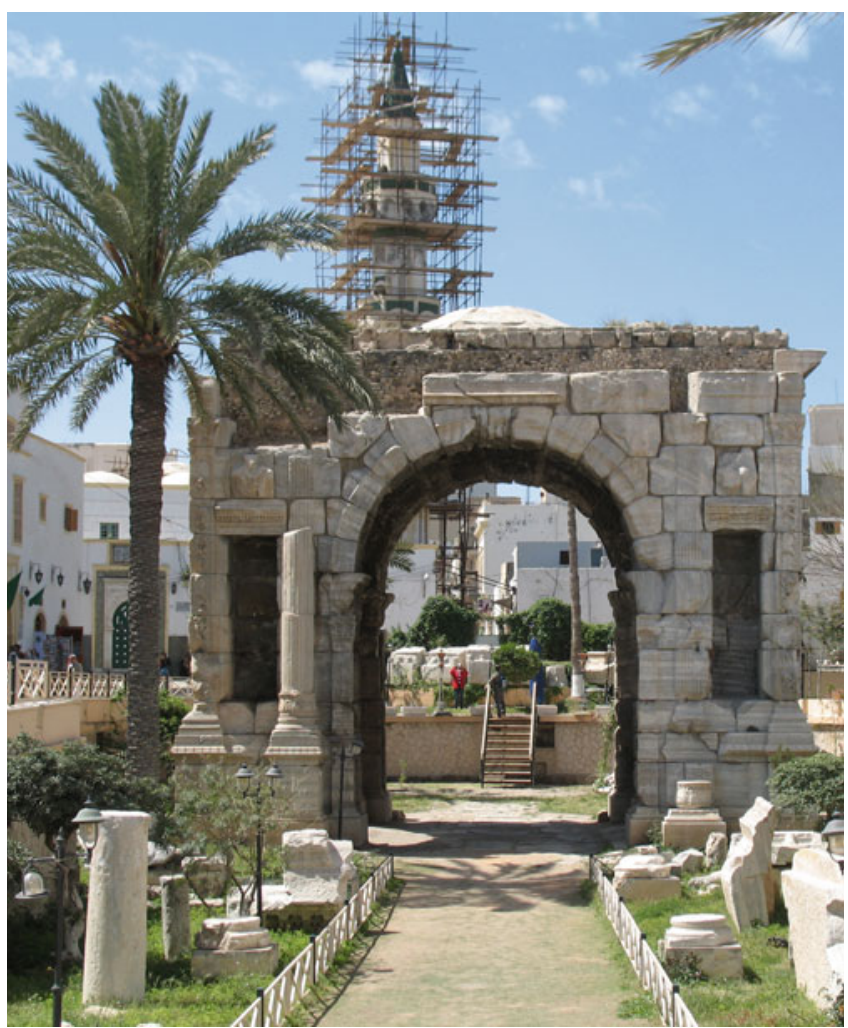

Fig. 6.24 Arch of Marc Aurel today (27)

and unworthy of the venerable Emperor, a Malti (Maltese) established a wine bar here. Even from the outside the building is partly obstructed by adjacent houses [...]." ${ }^{\text {49 }}$ The German researcher presents himself as an European beholder of the scene who places ancient tradition before all other urban developments. Gerhard Rohlfs, who travelled to Tripoli in 1868, also stressed the superiority of antiquity: "What strange fate had befallen this city and what does the future hold for it if it should be placed under the rule of an enlightened government just like Algeria. Was not the old Tripoli, that unity of three cities Leptis Magna, Oea and Sabratha, once one of the most flourishing and richest colonies on the northern shores of Africa?"50 The triumphal arch symbolises to him the glorious past of ancient Tripoli that should be revived again. Furthermore, he pointed out the conversion of the arch. In the meantime, a wine bar operated by a Maltese was removed from the arch, while Rohlfs makes it clear that this "[did not happen] out of reverence for a work of art from antiquity, but as there is a Turkish law according to which liquor bars can be established only at a certain distance from a mosque". ${ }^{51}$ The arc is located in direct vicinity of the Gurgi Mosque (75) that was built by Mustafa Gurgi in 1833/1834, who was the commander of the Tripolitanian navy, and who later became brother-in-law of Yusuf al Karamanli, the governor of Tripoli between 1795 


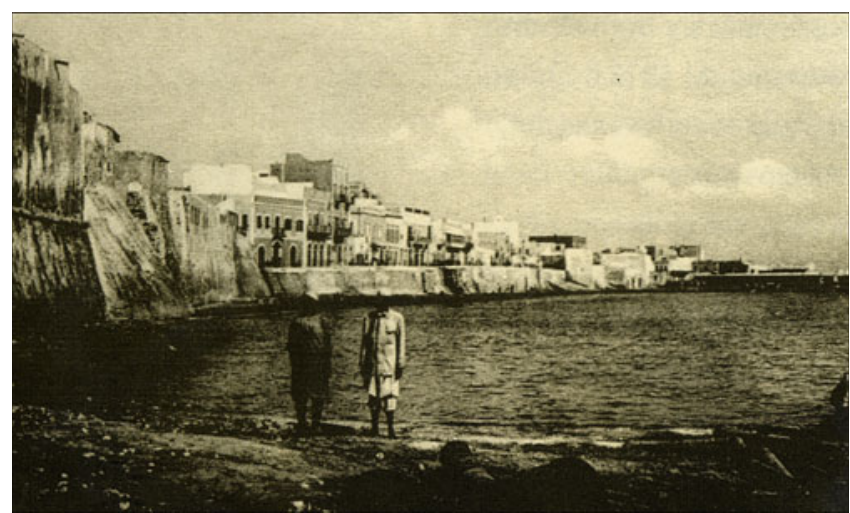

Fig. 6.25 Sea front of Tripoli at the end of the Ottoman era (Laronde 1997)

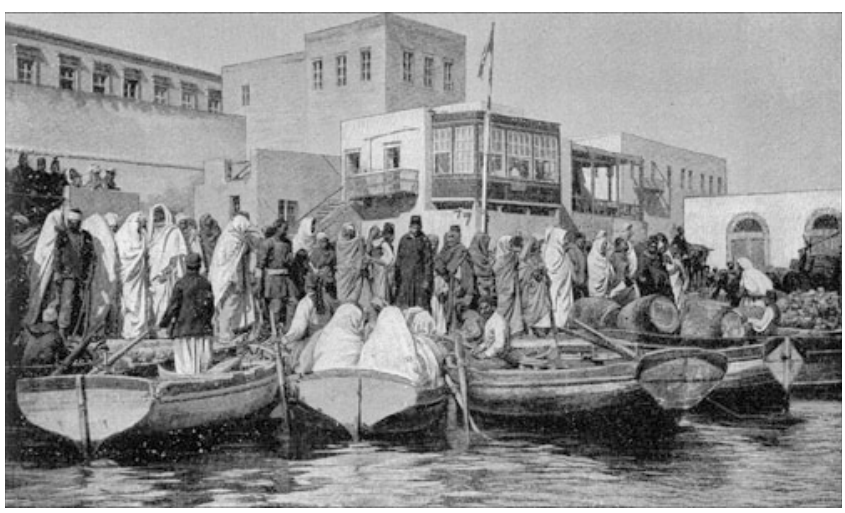

Fig. 6.26 Pilgrims in the port of Tripoli on their journey to Mecca (Mathuisieulx 1912)

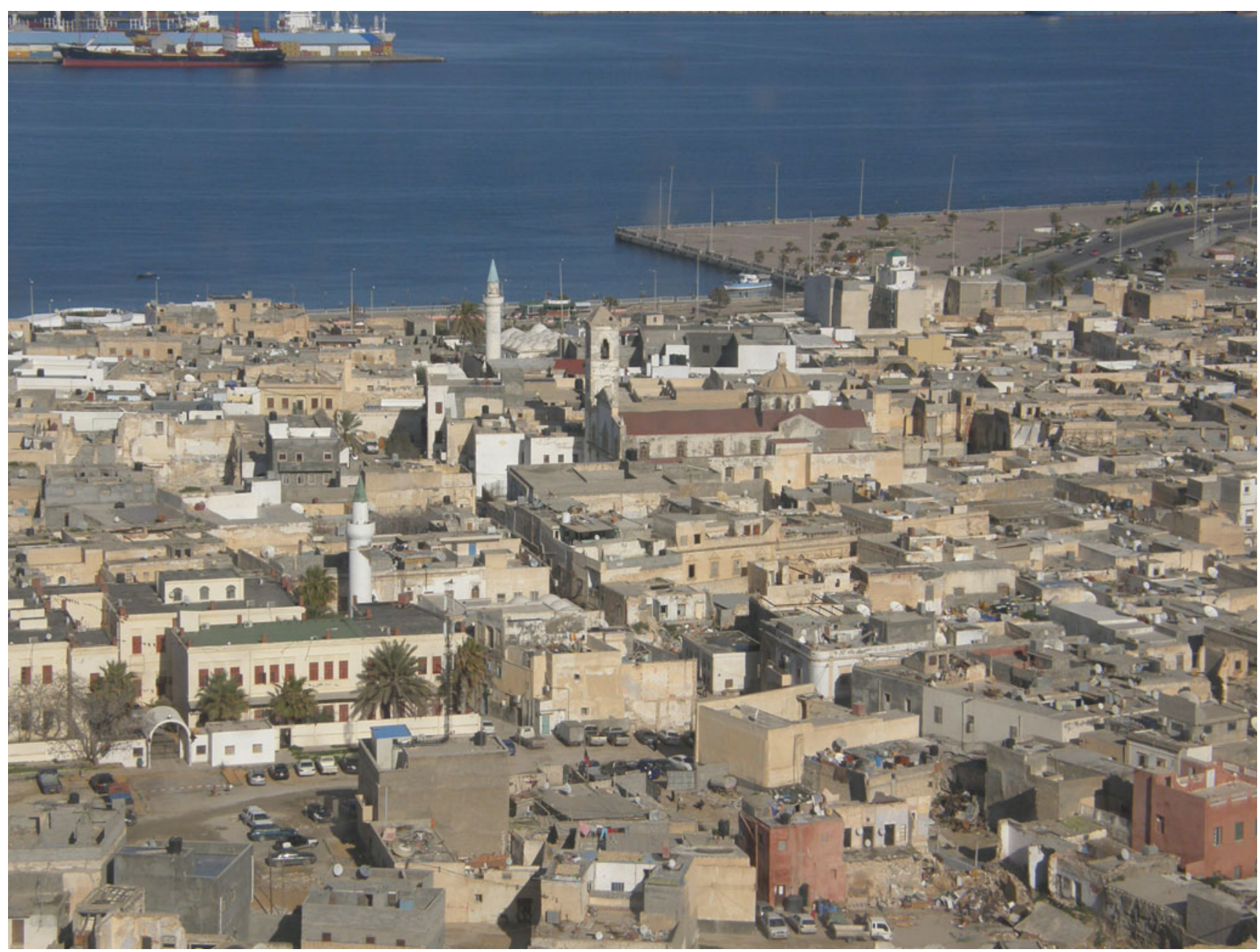

Fig. 6.27 Medina of Tripoli and part of the port as seen today

and 1832. The mosque is similar in structure to the Ahmed Pasha mosque (73). ${ }^{52}$ Both researchers overlook that over centuries, the arch had been granted a role in the context of the Medina that, in the end, prevented it from disappearing unlike all other monuments of the Roman city. ${ }^{53}$ Even the Arab pilgrim traveller Mohammed al Abdari expressed his enthusiasm in 1289 about the beauty of the arch and the used marble, building material which awakened desires as al 
Tigiani reported in 1307. A wealthy man of the city intended to use the arch as a quarry, whereupon the citizens of Tripoli converted the building to a mosque without further ado. At the end of the seventeenth century, the arch was threatened again with destruction. Mohammed Pasha Saqizli, governor of Tripoli between 1631 and 1649, tried in 1678 to profit from the building. Once again, the citizens of the city fought back referring to the fact that such an act would be a crime and that the building had been respected and honoured by the people of Tripoli for centuries. Thereafter, the arch seems to have been used for different purposes. It is recorded that between 1697 and 1818, it accommodated various shops. According to Rohlfs, even in the time afterwards, the arch had been continuously used as sources confirm, whereas the type of use had been subject to constant change. In 1887, the documented use of the arch was as a bar. In 1896, a Greek was said to have used the arch as a cheap restaurant. At the turn of the century, it was said to have accommodated again a bar, then a night club and finally a fruit shop. ${ }^{54}$ At the beginning of the Italian rule, there was a cinema in the arch. Entirely in keeping with Barths or Rohlfs, the Italian colonists finally removed all subsequent installations from the arch in 1912, wiping out all traces of its use after antiquity. During the colonisation of Libya, the Italians pursued a policy of an optically visible Italianisation of the country which was particularly visible in the promotion of archaeological excavations. ${ }^{55}$ The primary objective was the staging of two historical poles, the period of North Africa under Roman rule and the country occupied by the Italians. These measures went far beyond a mere archaeological conservation or modern restoration of the ancient monuments. After having removed, in the eyes of the Italians, evidence of the less glorious historical phases, antiquity was represented in line with fascist ideas. The complete excavation of the arch and its reconstruction led to its release from the sphere of regular historic preservation. The archaeological conservation took second place to the political staging. In this sense, the building density of the
Arab-Ottoman Medina surrounding the arc was gradually pushed back to create a free zone around this most important relic of Roman Oea. ${ }^{56}$

Today, Tripoli and its surroundings form the largest agglomeration in Libya which consists of the shabiyat of Tripoli, Tajura and al Jfara and currently extends over an area of almost $3800 \mathrm{~km}^{2}$. According to the census of 2006, Tripoli is occupied by two million inhabitants. Today, Tripoli has become two cities in one, with fundamental differences in its structural order similar to what can be found in many other cities of the Arab region (Figs. 6.25, 6.26 and 6.27). ${ }^{57}$

\subsection{Nalut-a Fortified Granary in the Nafusa Mountains}

\section{Said Hamid}

The city of Nalut is located to the south-west of Tripoli. It lies approximately halfway between Tripoli and Ghadamis, at the western end of the Nafusa Mountains coastal range, and is situated at latitude $31.45^{\circ}$ north and longitude $11.05^{\circ}$ east.

\subsubsection{Desert Transit Centre}

Nalut owes its importance to its distinct geographic location, poised as it is on the caravan routes linking Tripoli, Ghadamis and several Tunisian cities. It was one of the desert transit centres, where caravan traders used to halt for periods of rest. Water and pasture were not only available in the neighbouring valleys but also within the city limits itself. There, one would find numerous springs of fresh water, such as the Tala and the Tighlis springs. Moreover, the surrounding region produced figs, olive oil and cereals. The region also became famous for some traditional products, most important of which is the item of Libyan traditional clothing known as the Naluti huli or jird. This was made of
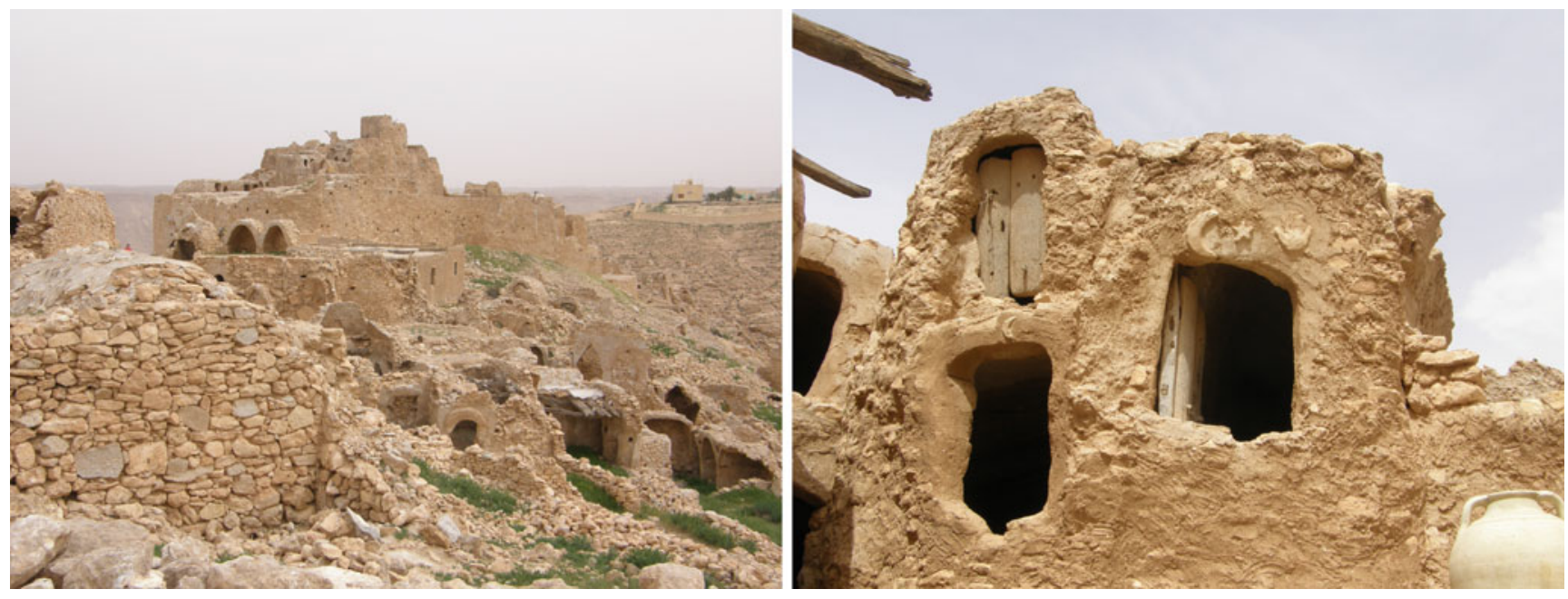

Fig. 6.28 Nalut is home to a qsar, which is a fortified granary with a small market, a special place for meetings and storage rooms 


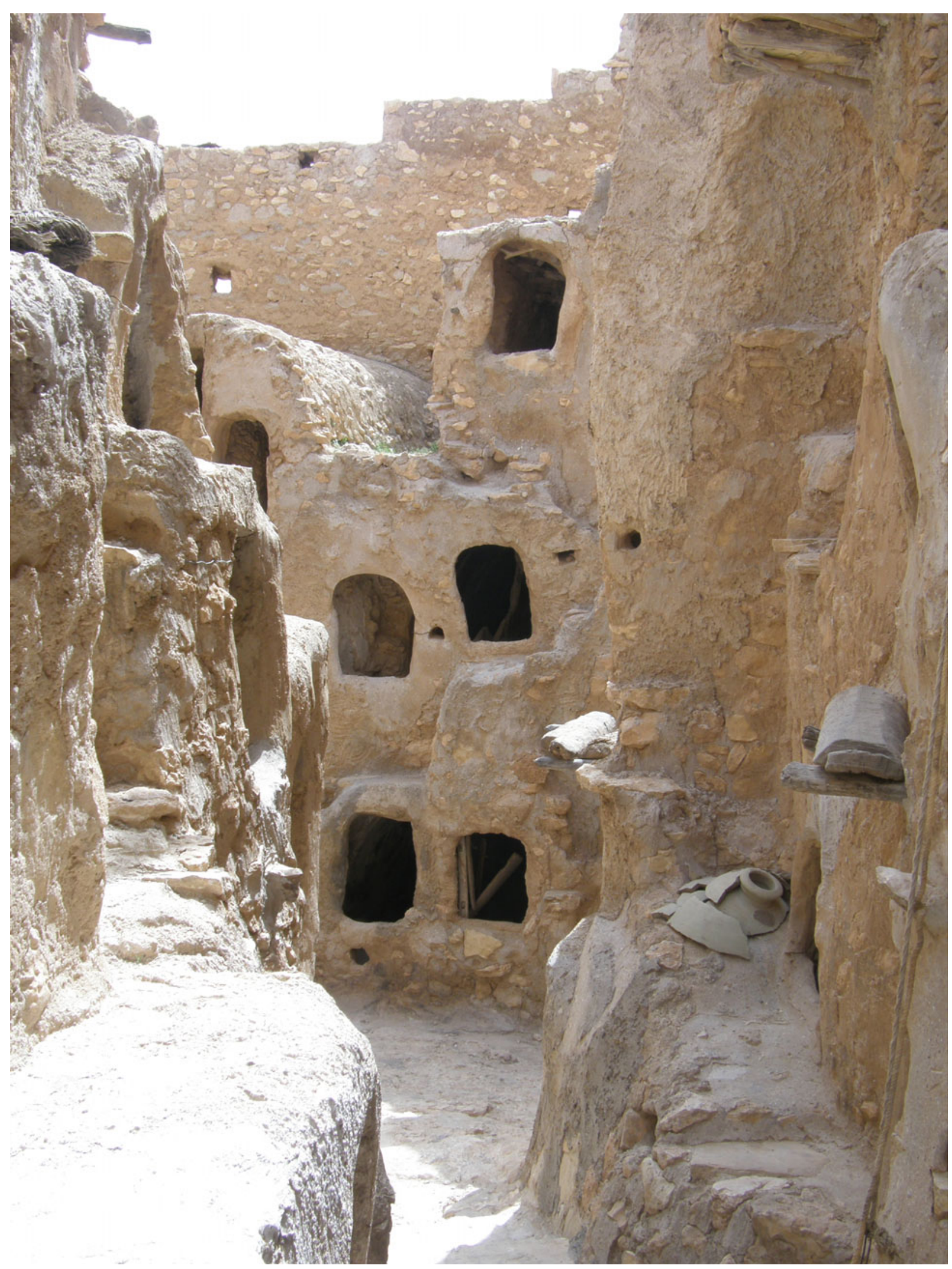

Fig. 6.29 Nalut once linked the routes from Tripoli, Ghadamis and Tunisian cities. The qsar Nalut was a communal building, which housed more than 400 rooms, where local families could store their grain, olive oil and dried fruits. Next to the qsar, there are still houses in local style and several mosques 
pure white wool and famous for its high-quality manufacture. In addition, the people of Nalut were engaged in some traditional trades, such as the production of clay utensils and leather products. Among the most important landmarks of Nalut, one could mention its huge palace, built in the eleventh century. This palace housed more than 400 rooms, which were used for the storage of olive oil and cereals. In the settlement itself, there were many traditional oil presses and old mosques as well as underground chambers in which people used to live (Figs. 6.28 and 6.29).

Nalut was linked to the caravan route from Jadu, or from the cities of the Jafara plain. Caravans took the route from Tripoli, al Aziziya, Bir al-Ghanam, al-Jush and Tiji to arrive at Nalut. From there, the route proceeded towards Sinawin, Dirj and Matris until it reached Ghadamis. From Ghadamis, the route proceeded to Ghat and from there to the central and western lands of the Sudan. This route witnessed considerable caravan commercial activity, and merchandise was exchanged between the Mediterranean and the African ports during periods of security and stability which characterised the eighteenth and nineteenth centuries. Towards the end of the nineteenth and the beginning of the twentieth centuries, the route was influenced by the commercial recession that was a result of the drop in demand for sub-Saharan products. This led to a demise of the economy of the town. The adoption of alternative maritime, riverine and land routes leading to the interior of the African continent, precipitated the end of caravan trading.

Nalut was linked to another route which witnessed considerable commercial activity in the beginning of the nineteenth century. It passed through the city of Wazin in the direction of the city of Dheybat. From there, the route proceeded towards the other Tunisian cities in the north. It was one of the important commercial bridges linking the traders of the Nafusa Mountains and Ghadamis with Tunisia and the countries of the Arab Maghreb. This route was impacted by the French occupation of Tunisia in 1881 and consequently lost its commercial importance. ${ }^{58}$

\subsection{Ghadamis_-"Pearl of the Sahara"}

Jacqueline Passon

Ghadamis, known as "the pearl of the desert", is located at the edge of the Sahara Desert, close to the Libyan-Algerian border. It is an outstanding example of a traditional settlement.

The oasis town of Ghadamis lies in the northern part of the Sahara, surrounded by a ring of date palms. In the past, the town performed an important function as a transportation hub for trans-Saharan trade. Its position on the northern edge of the Sahara lends Ghadamis its strategic significance: five caravan routes have their crossroads here. Several springs formed the foundation of the place, of which the best known is the Ain al Faras, which has almost run dry today. Intensive market gardening was made possible by this water. Until well into the nineteenth century, Ghadamis was an important staging post for trans-Saharan trade.

\subsubsection{Ain al Faras-Source of Life in the "Most Barren Desolation"}

The first reports of Ghadamis (Fig. 6.30) are from ancient times. At that time, Roman troops were stationed temporarily in Cydamus, as it was known in Latin. ${ }^{59}$ According to the English historian Goodchild, the Romans constructed a fortress in Ghadamis between 201 and 235. ${ }^{60}$ In Byzantine times, in the sixth century, the oasis had a church and was the seat of a bishop following the conversion of the population to Christianity. The "idols" which stand nearby the old town are of ancient character, and it is supposed that they are Byzantine mausolea. In the seventh century, Ghadamis came under the domination of the Muslim Arabs and the population quickly accepted Islam as their religion. The Arab conqueror, Uqba ibn Nafi, had occupied the oasis with a detachment of cavalry between his conquest of Fezzan and his march on Gafsa in 667. Between the eighth and tenth centuries, the oasis became Ibadi and developed into a trans-Saharan port. ${ }^{61}$ Consequently, it is not surprising that fourteenth-century historian Ibn Khaldun reported the significance and prosperity of Ghadamis: “...today Ghadamis is a greatly populated city. It is a stopping place for pilgrims from the Sudan and for traders on their way from the Maghreb to Alexandria and Cairo."62

Leo Africanus, the papal historian of the Orient, located sixteenth-century Ghadamis in a desert that was "very dangerous for travelling salespersons". 63 Travellers from Europe first arrived in the town in the nineteenth century. Foreigners, like the Christians from Europe, were eyed with suspicion and curiosity. Ever since the 1860s, it had not been a matter of course to let Christians into the desert city. Since the French conquests in Algeria in that century, sufficient bad experiences had been collected of the colonial ambitions of Europeans. ${ }^{64}$

To James Richardson, an English explorer in Africa, the view of the city seemed like deliverance from the desert. He noted on his 23 days lasting journey on the route from coastal Tripoli to Ghadamis in 1845: "Just when day had broken over half the havens, I saw Ghadamis! Witch appeared like a thick streak of black on the pale circle of the horizon. This was its date-woods. I now fancied I had discovered a new world". 65 The landscape around Ghadamis seemed inhospitable, not only to the English explorer. The Austrian geographer and world traveller Josef Chavanne spoke of the "most barren desolation". 66 The reason that humans have settled here over such a long period of time can be seen in the variety of trade routes between the 

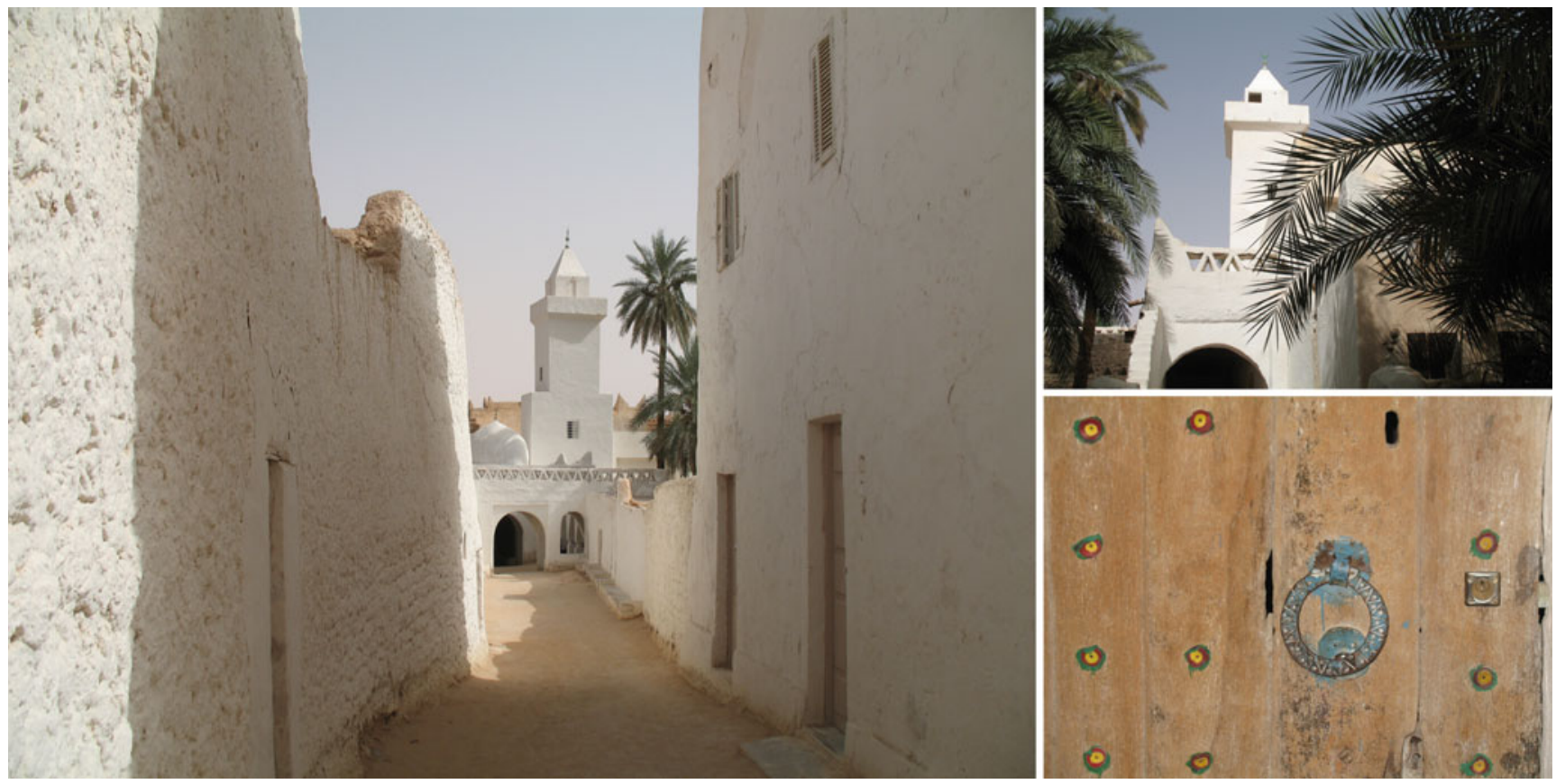

Fig. 6.30 View on one of the mosques of the oasis. During the sixth century, the population had been converted to Christianity by Byzantine missionaries. But in the seventh century, Ghadamis was conquered by Uqba ibn Nafi and the population quickly converted to Islam. Then, Ghadamis played an important role as base for the trans-Saharan trade until the nineteenth century

Mediterranean coast and the African interior. This may have been a very important (if not the most important) circumstance in the prosperity and growth of the area.

The survival of humans in such a hostile place was and still is first and foremost dependent on access to the resource of water. The houses stand closely together with their flat roofs and accessible terraces. Dark, shady alleys all lead to the large square in the centre of the city, where the source of life in Ghadamis is found. This spring, according to Rohlfs, is "the creator of the oasis and therefore the founder of the city (...)". ${ }^{67}$ The town is laid out around the artesian Ain al Faras (1) (Figs. 6.31 and 6.32). This limited water supply necessitated the functional arrangement and formal construction of the oasis. The old core of the oasis, which is completely surrounded by a wall, measures around two kilometres in diameter. ${ }^{68}$

The irrigated area would not have been greater than 75 ha and would have been divided into countless small parcels. The spring "is collected in a elongated square basin, $25 \mathrm{~m}$ long [and] $15 \mathrm{~m}$ wide, from the floor of which one can see the water springing up in several places" ${ }^{\prime 69}$, reported Chavanne in 1878. After the water had been collected in this way, it was channelled to the gardens in three ditches towards the east, north and south. In order to guarantee exact sharing of the water among the individual parcels of land, special clepsydras were used, known as al Quadus (2). From Rohlfs, we know how they worked: "An iron pan with a round opening in the bottom, through which the water, when filled to the top, will flow out in about three minutes. Every time a Gaddus is passed through, a lad employed for this purpose, who after a certain time will be relieved by another, makes a knot in a palm leaf. Seven Gaddus is called a Dermissa and this gives around twenty minutes irrigation, enough for a garden with sixty palms."

The permanent population of the oasis was around 7000 according to Chavanne's data. After the arrival of a caravan, this could however grow by a further $1000 .{ }^{71}$ Other sources even suggest a population figure of 12,000 in the year 1880, which would have made Ghadamis one of the largest oases in the Sahara. ${ }^{72}$ Each of the seven clans living in Ghadamis had its own urban district with its own social institutions like celebration and meeting areas (see map: Population groups). Inhabitants of the oasis were mostly Berber of the Bani Wazit and Bani Ulid. They resided in six of the seven district areas. The Awlad Bellil, who considered themselves of Arab origin, lived in one district. They used to live as "enemies", shut up in seven districts isolated from one another by walls whose gates were shut at night. But despite these divisions, the little urban centre of Ghadamis has been able to maintain trade successfully across the centuries and, for a long time, its independence. ${ }^{73}$ Besides the caravan trade, the main source of income for Ghadamis residents was agriculture. The town lay in the middle of the desert, not in a highly favoured placelike Tripoli on the Mediterranean coast - but it still managed to offer its inhabitants a prosperous life. ${ }^{74}$ Agriculture comprised for the most part fruit, vegetable and grain cropping. 


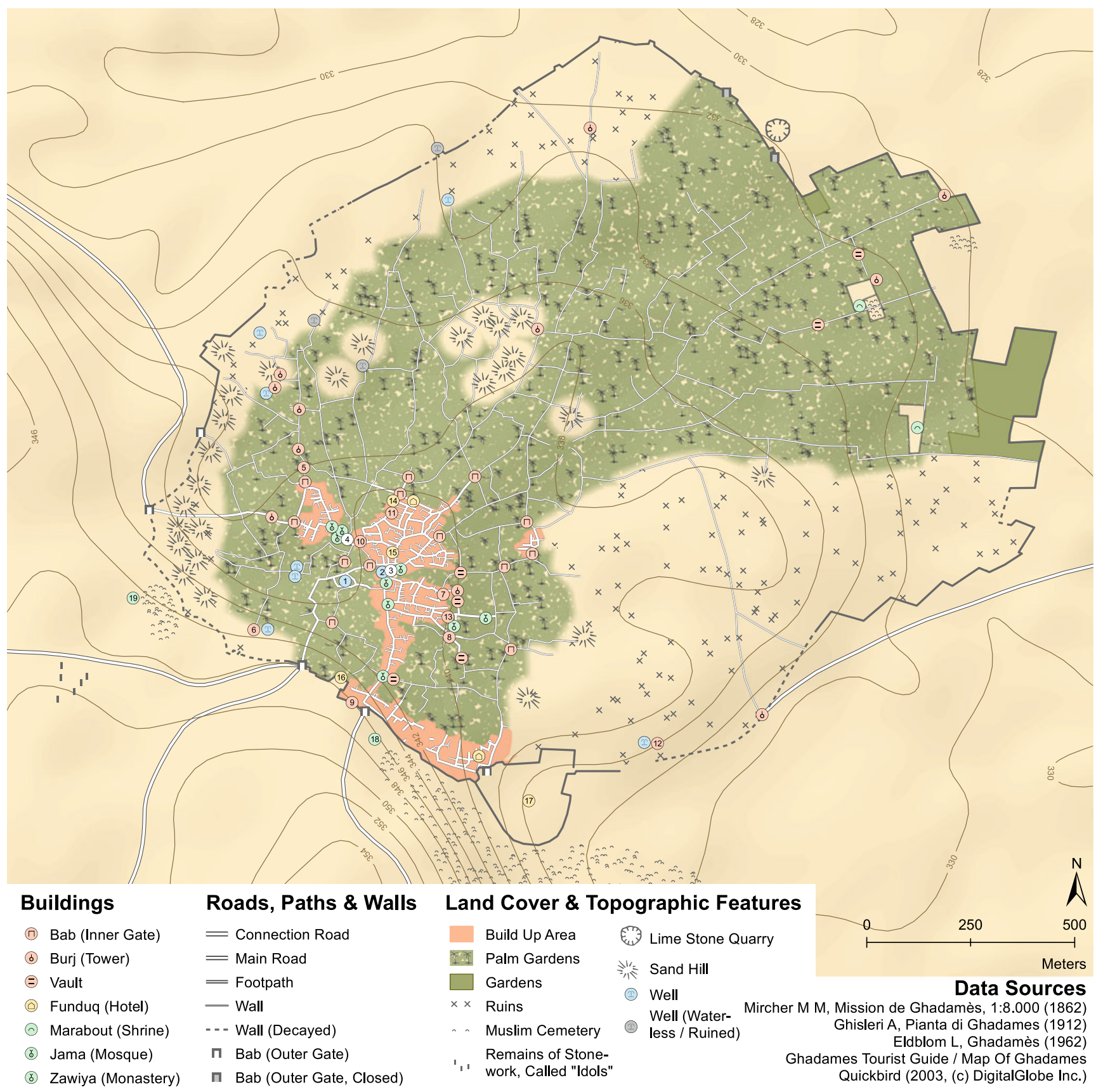

\section{Important Places}

(1) Ain al Faras

(2) Al Quadus (Water Watch)

(3) Suq al Qoudar (Old Market)

(4) Suq al Touta (Slave Market)

(5) Public Oven

(6) Staircase

(7) Hush Ali Bay

Hush Mudir (Ancient English Con-

sulate / House of James Richardson)

Hush Souafa (House

of the People from El Oued)
(10) House of Capitain de Bonnemain

(11) House of Henry Duveyrier

(12) House of Major Laing, Decayed

(13) House of the French Mission

(14) English Consulate

(15) French Consulate

(16) Campground of Ali Bay

(17) Rest Area

(18) Jama Sidi al Badri

(19) Tomb of the Son of Ikhenukhen

\section{Population Groups}

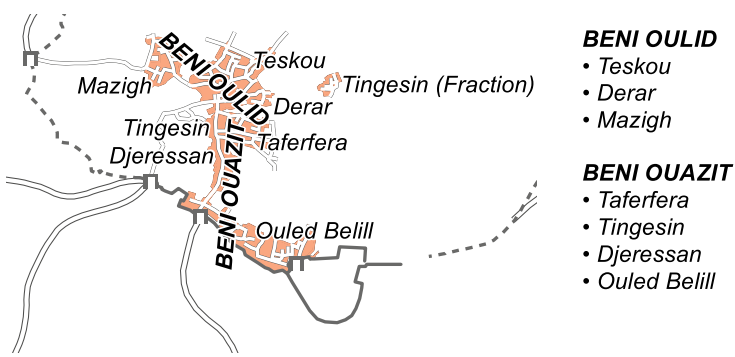

Fig. 6.31 Map of Ghadamis in 1862 

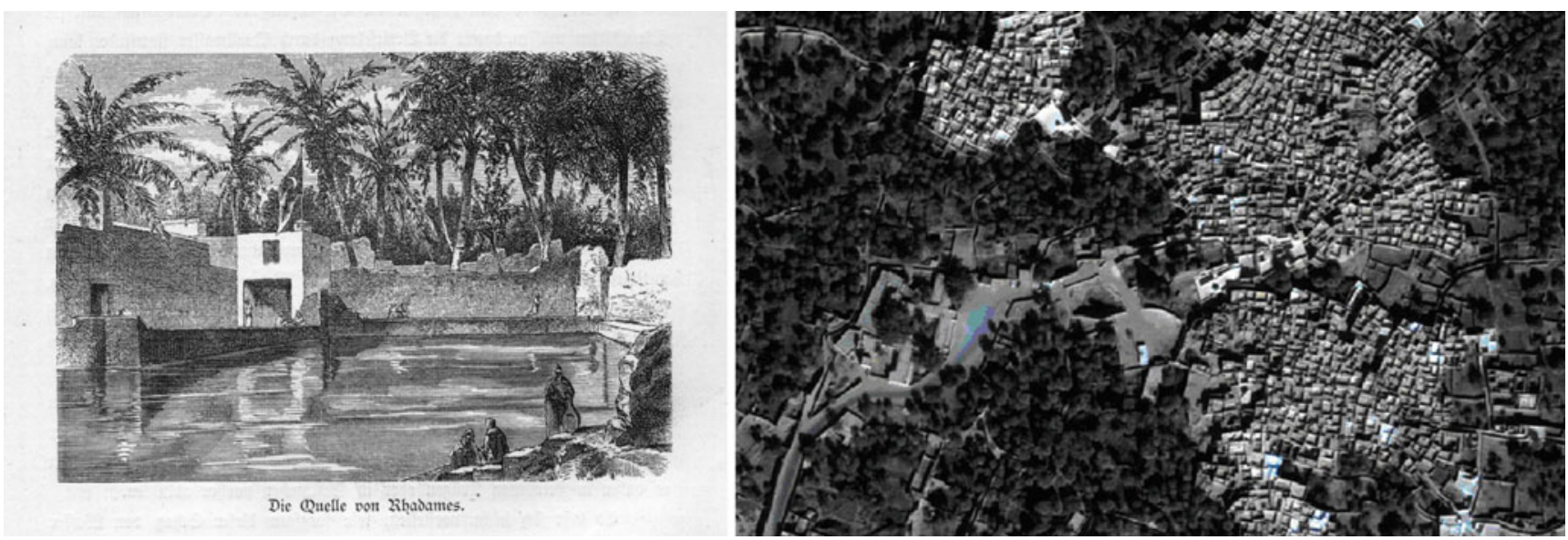

Fig. 6.32 Ain al Faras as seen by the Austrian traveller Josef Chavanne $(1879,223)$ in the 19th century and from a satellite perspective (Quickbird)

The gardens can be imagined as a house with three floors: on the lowest level field crops such as wheat, barley and/or millet were grown; above them, fruit trees and/or olive trees were cultivated; finally, the palms were on the highest level, which gave shade and offer protection. ${ }^{75}$

\subsubsection{Desert Architecture}

The climate in this region is characterised by extreme temperature contrasts. Due to the climatic conditions and the lack of building materials, the residents developed an idiosyncratic desert architecture that, according to reports of travellers, had a rather unfriendly effect. In 1867, Rohlfs described it as a fortress: "The town of Rhadames compares externally (...) with its close-built, many-storey houses, whose naked walls are only here and there at the highest level punctured with a tiny window opening, with a compact, irregular, walled-up fortress". ${ }^{76}$

James Richardson also remarked that the walls looked as if they already bore the weight of thousands of years, and he mentioned the narrow, oppressive alleys. ${ }^{77}$ The houses themselves were constructed from bricks formed from clay, palm leaves and lime. Due to its excellent adaptation to the climatic conditions, this construction method is still used today, for example, in the Egyptian oasis of Farafra. Nowhere in Libya is a better adaptation of housing to local climatic conditions to be found than in Ghadamis. ${ }^{78}$ The houses are so arranged that a house often shares all four walls with its neighbours, lending the town an interlaced, labyrinthine appearance. Even the streets are covered, and the covers are furnished with shafts to provide light and ventilation. They not only performed the function of giving shade, but they also served purposes of defence and gender segregation. Rohlfs reported that the women of the town did not choose the streets as their paths; like a "higher town", the flat roofs were reserved for them. These served so to speak as "women's roads", at which men could hardly even glance. ${ }^{79}$ Eldblom came to the conclusion that, due to the inhospitable surroundings, a very specific social and economic structure had developed in the isolated oasis. ${ }^{80}$ Ultimately, he took a natural deterministic view here, postulating the specific qualities of the natural environment as the origin of development for different forms of organisation in a community. But the image of a closed society was also conveyed through nineteenth-century sources, a society which barely accepted foreign influences, the power of the central government or change (Figs. 6.33, 6.34, 6.35, 6.36, 6.37, 6.38 and 6.39).

Ghadamis might have consisted of several qsur in the sixteenth century. But then, it seems to have become concentrated into a single village which has preserved its appearance until today (Fig. 6.41). Its inhabitants were able to stay independent. This independence was only limited by the obligatory association with the Tuareg Adjer, at the extreme limit of whose territory Ghadamis was situated. Moreover, the Ghadamis people always maintained close ties to Tunis and Tripoli. The oasis suffered several attacks by Hafsid and Turkish troops but always managed to free itself rapidly from the taxes imposed by Tunis. It was nonetheless obliged to recognise the authority of the Turks of Tripoli in 1860. After 1874, it was given a little garrison; however, it continued to administer itself with a shaykh formed from the heads of noble families. ${ }^{81}$ 


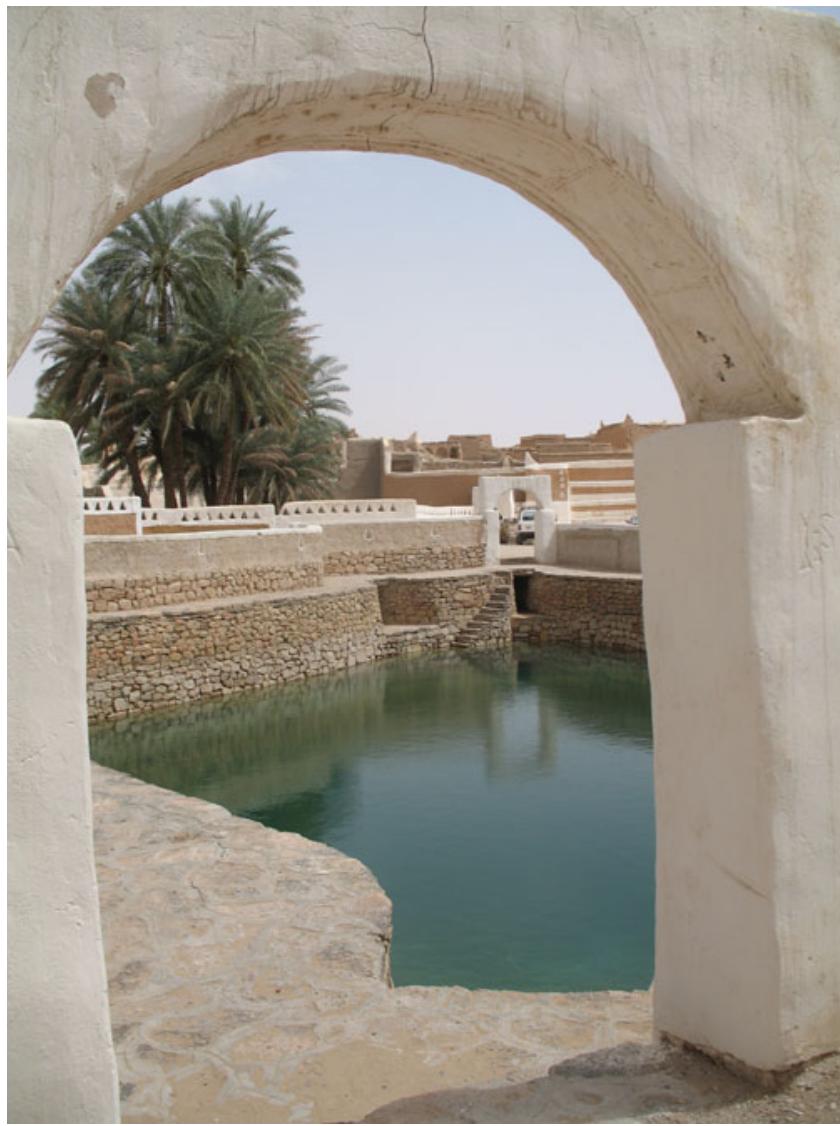

Fig. 6.33 Ain al Faras as seen today

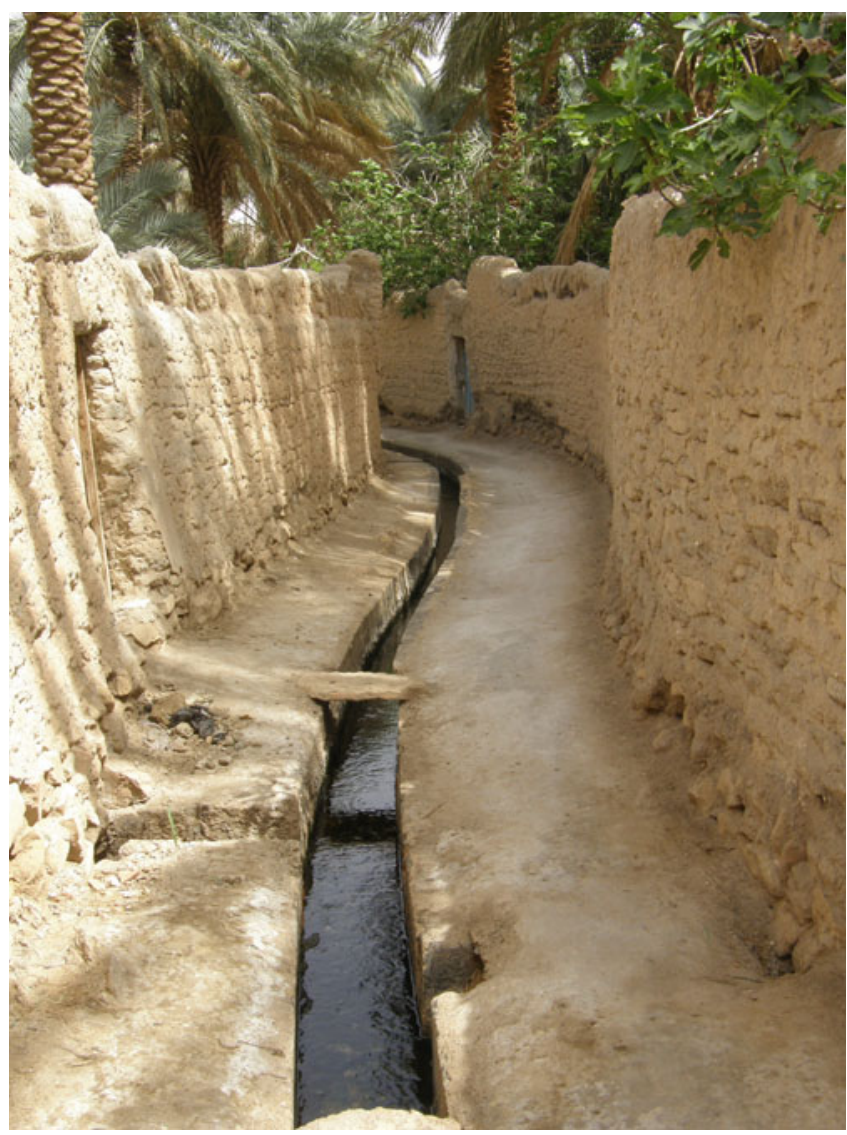

Fig. 6.34 From Ain al Faras, the water runs via water lines to the houses and gardens

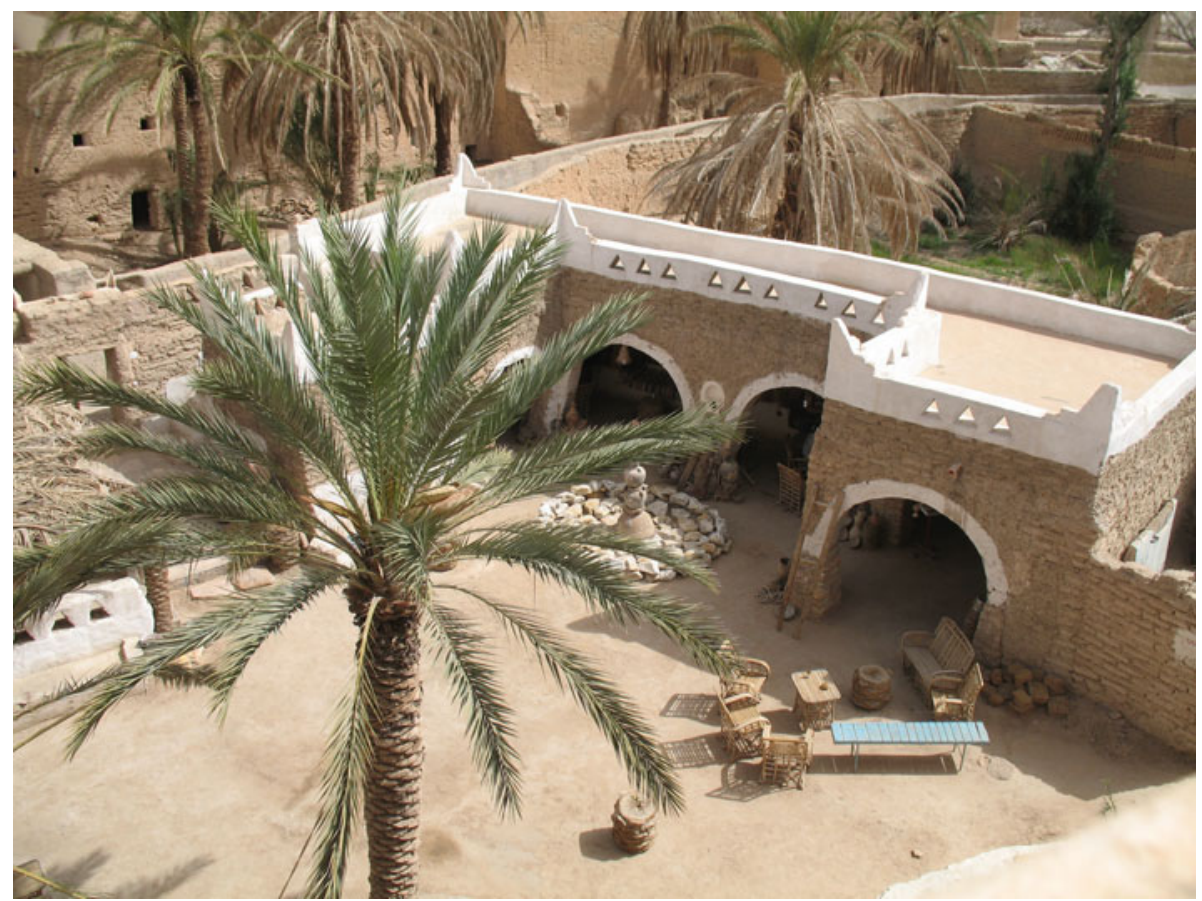

Fig. 6.35 View from the top of one of the houses. The open-air terraces were reserved strictly for women 

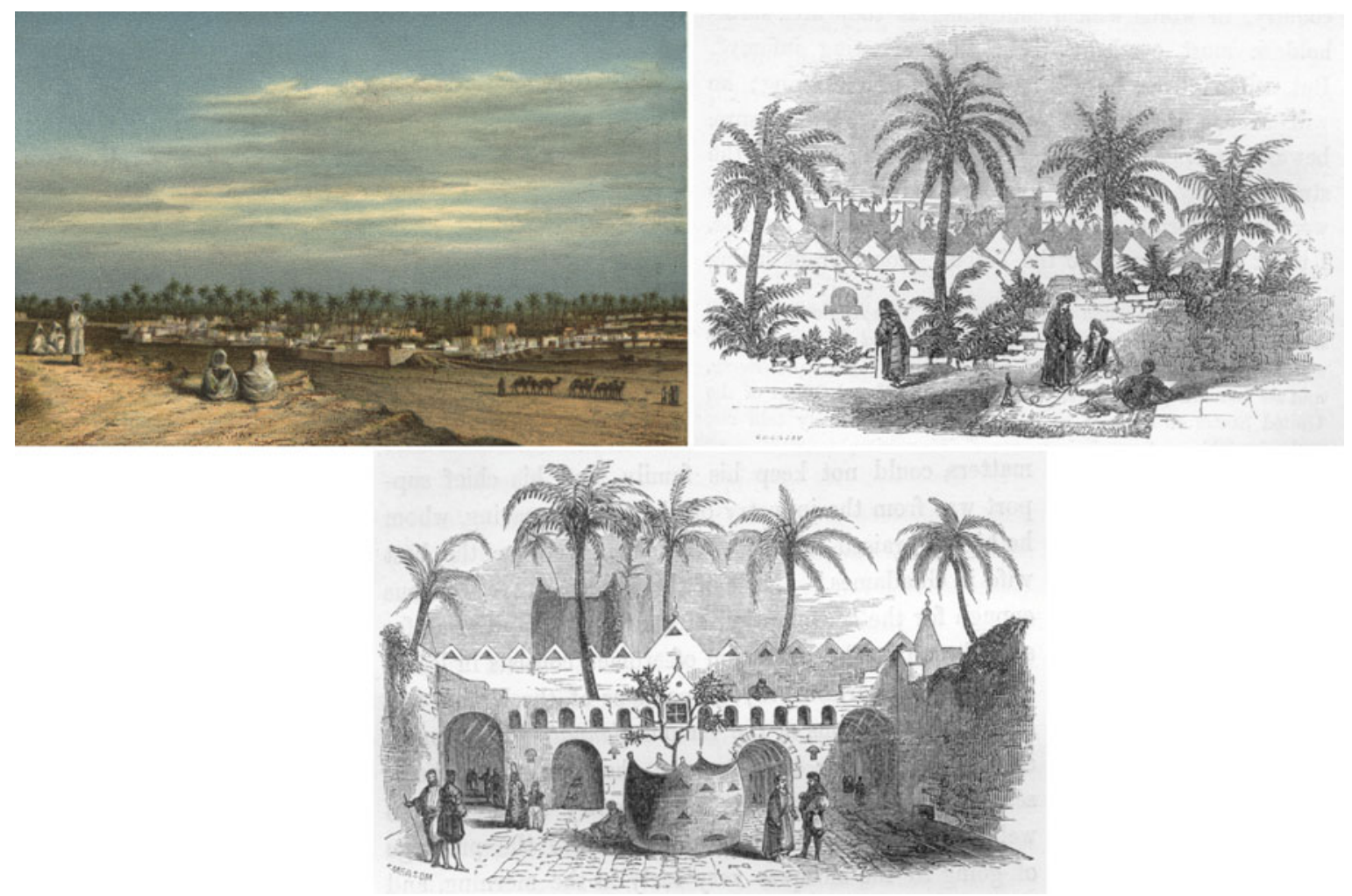

Fig. 6.36 Ghadamis in the view of Chavanne $(1879,225)$ and Richardson $(1849,225,268)$. Ghadamis is one of the oldest Saharan settlements. The oasis settlement is built entirely out of mud and it is almost completely covered. It is not surprising that this ancient design has been invented in the Sahara: the mud houses maintain a cool town in summer and a warm habitat during cold winter nights. In addition to protection from the burning desert sun, the roof of the city acts like a separate city with complete open streets and lanes, exclusively used by women. This gave them the chance to move undisturbed from one house to another. Ghadamis has been declared a World Heritage Site by the UNESCO in 1986

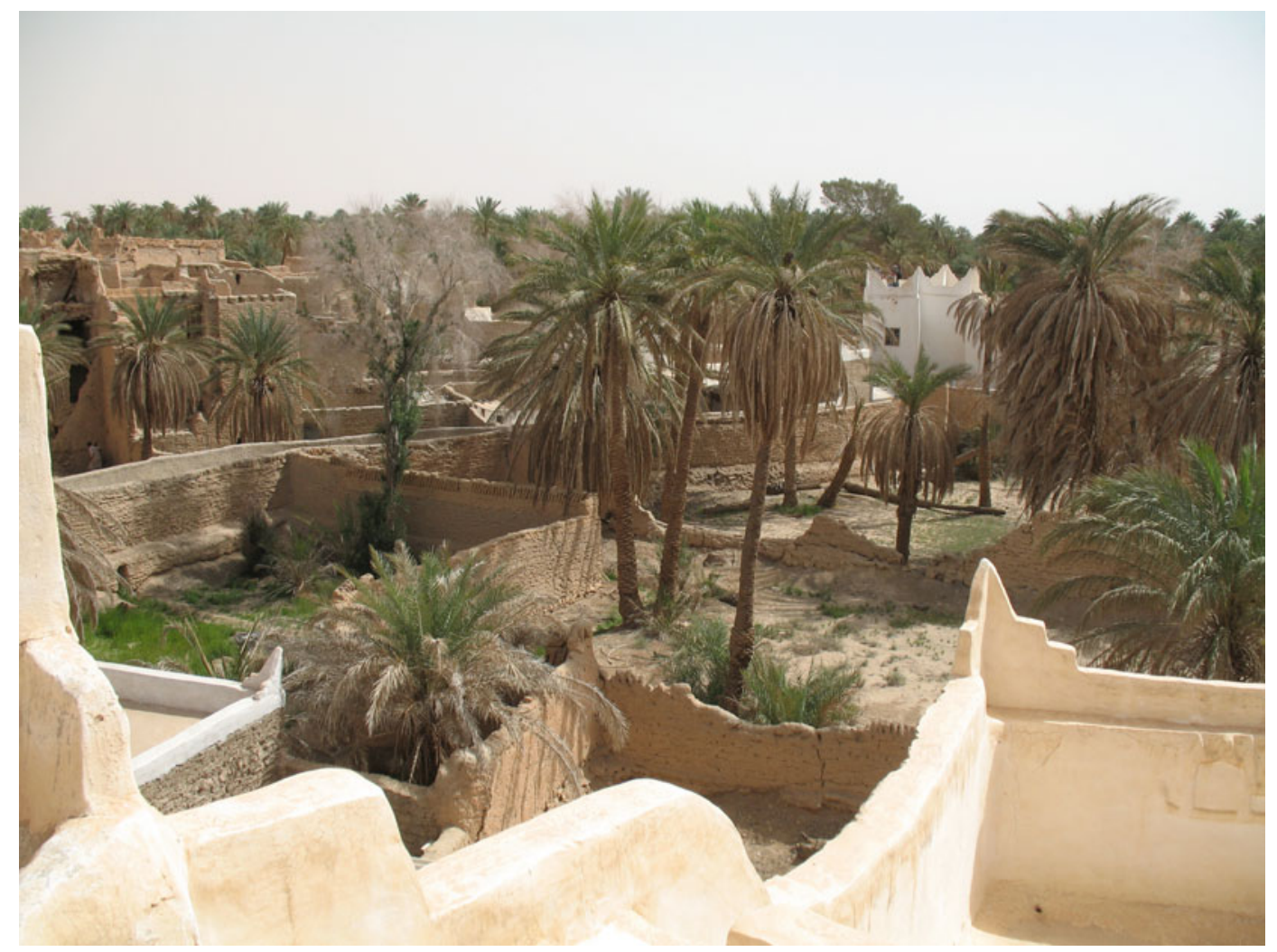

Fig. 6.37 The gardens were organised vertically, palm tree (date palms), then fruits, creating the necessary shade for crops 

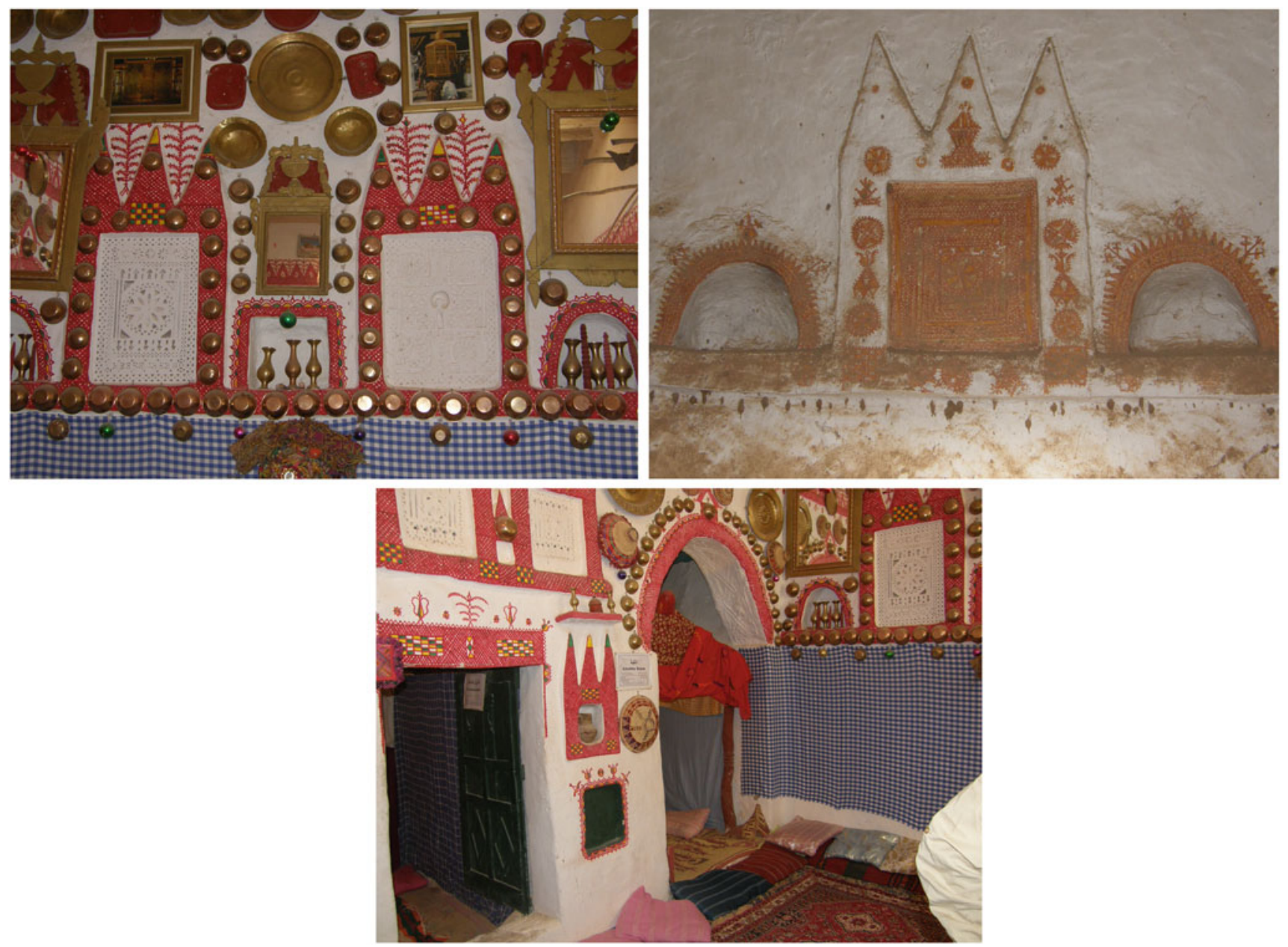

Fig. 6.38 Interior wall designs and house decorations from Ghadamis: the interiors of the houses are painted with unique Berber designs, using red paint on white walls. The inhabitants also decorated their rooms with hanging ornaments. This gives the rooms a fascinating atmosphere, which makes Ghadamis unique. The traditional Berber designs used to include the triangle, the diamond, the sun, the moon, the palm, the eye, the hand and the Tuareg cross. The objects used to decorate the rooms include mirrors, ornaments made of palm straw, brass and copper, as well as Berber carpets, rugs and cushion

\subsection{3 "Trade Negotiator" Between the Mediterranean and the African Interior}

Trade was a primary source of income for the city. Traders from North and Central Africa met in Ghadamis. Caravan routes led to the north towards Tunis and Tripoli. In a southerly direction, the routes led via the deserts towns of Ghat and Murzuq on the one hand to the legendary Timbuktu and on the other hand to the Bornu Empire. Ghadamis was more than just a transportation hub in this trade network. The inhabitants themselves travelled as sales people throughout North Africa. The extreme points of their journeys were Tunis and Tripoli in the north, Agades, Kano and Timbuktu in the south. Of a total of 7000 people living in the town in 1867 , around 1000 were constantly on the road with various caravans. Chavanne described the role of the traders from Ghadamis as the "negotiator of trade between the Mediterranean and Central Africa". ${ }^{82}$ Textiles, glass beads, essences and other goods from the north were exchanged for slaves, ivory, ostrich feathers, leather, hides and gold from the south. Gold and slaves were among the most significant trading goods. ${ }^{83}$ However, since the time of the African explorers of the nineteenth century, the gold trade from the African interior had developed to a greater extent via the European trade settlements on the African west coast. At the start of the nineteenth century, Ghadamis was primarily an important post for the trans-Saharan slave trade (Fig. 6.40). This was also attributable to the good relationship of the town with the surrounding Adjer-Tuareg, who provided camels and guaranteed protection during transport, as well as being hired as travel guides for caravans. With the French conquests in North Algeria (1830-1840) and the banning of the slave trade in Tunisia (1840s), Ghadamis saw itself 


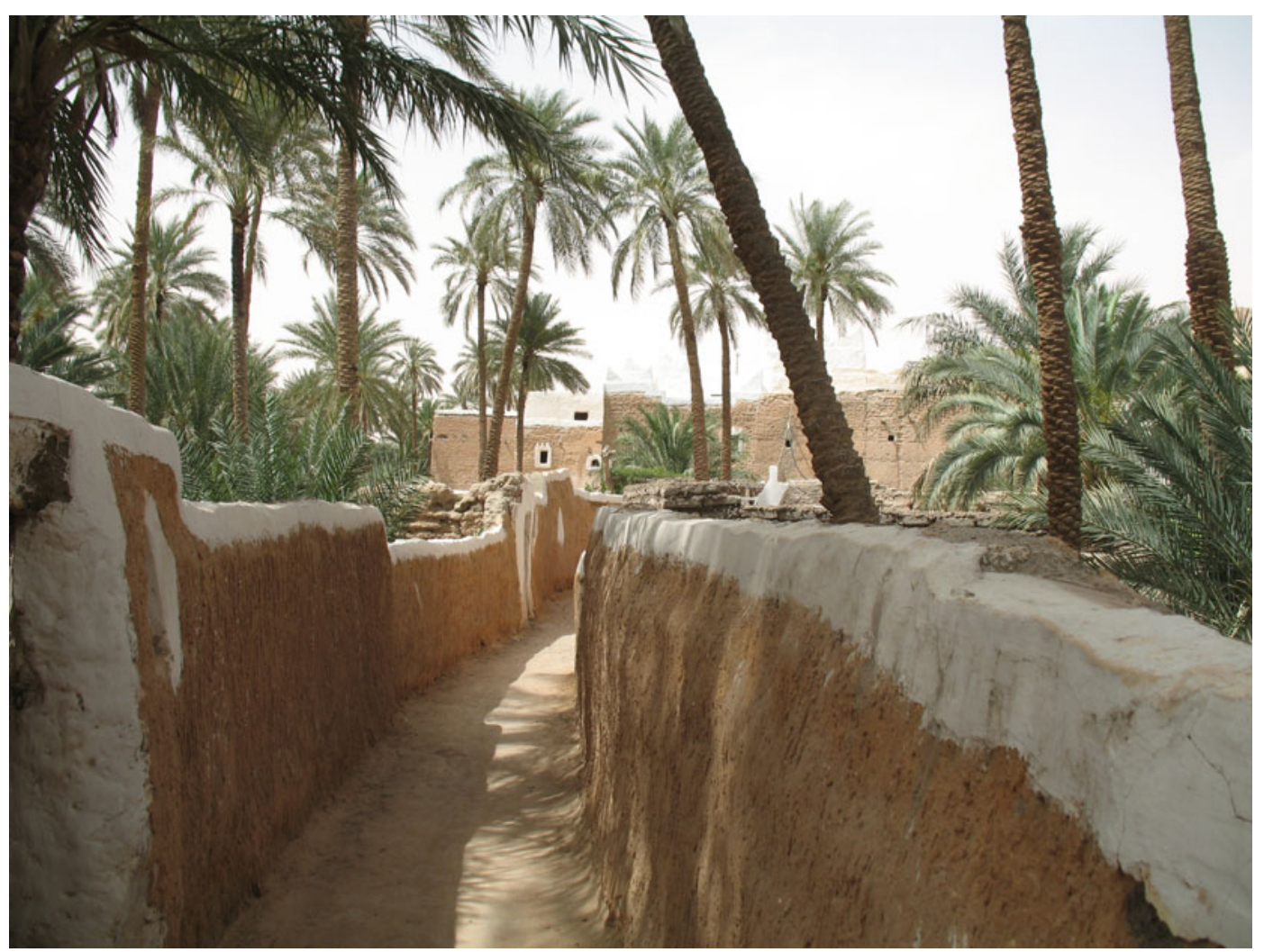

Fig. 6.39 One of the ancient streets of Ghadamis. Shade is bestowed by the palm trees

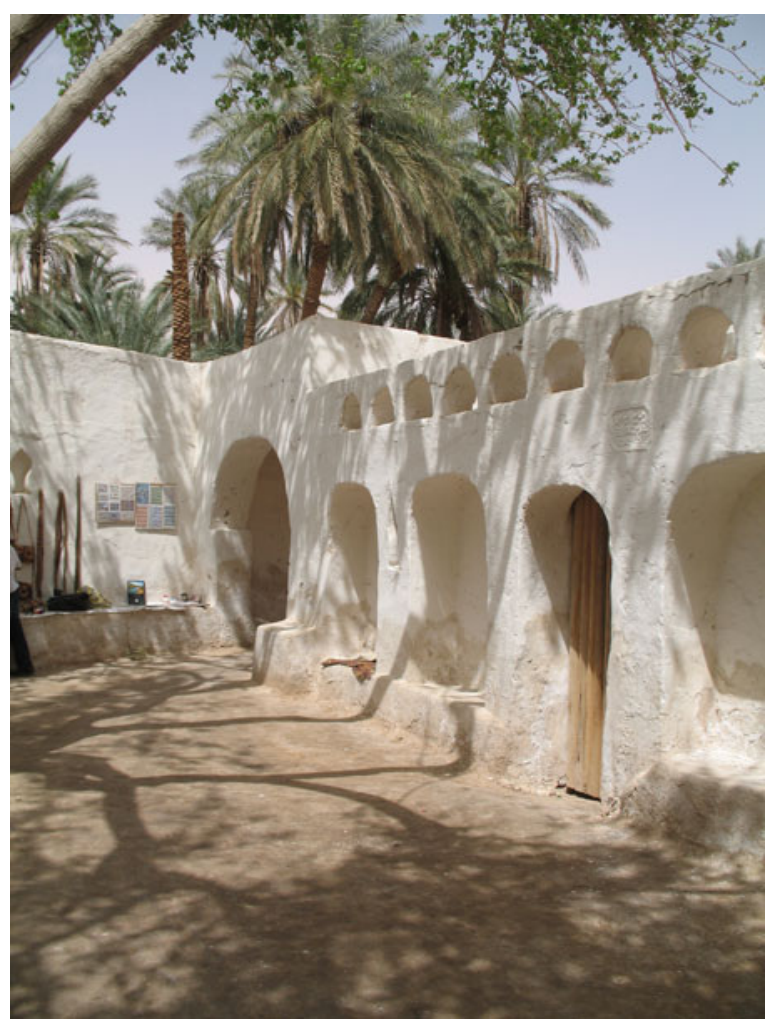

Fig. 6.40 Former slave market of Ghadamis (4) robbed of its most important export markets. Added to this came high Ottoman taxes and an increasing insecurity of the trade routes, especially the route to Tripoli. In the last third of the nineteenth century, the decline of trans-Saharan trade in Ghadamis became apparent.

In the mid-twentieth century, there was still trade in Ghadamis, although it only took place on a local level. The negative developments also impacted craft activities as well as agriculture. The artisans, once very affluent, and since the eleventh century famous for their hides, have almost ceased to exist, they lacked raw materials. ${ }^{84}$ Besides this, agriculture was in decline at that time. The extremely unequal property situation had a particularly limiting effect on cultivation. The sale of property was not permitted. Furthermore, income had to be divided within each family, which considerably minimised personal income. Finally, families consisted of up to 100 people.

The mechanisation of cultivation was hindered by the walls that surrounded each little garden. In fact, the traditional cultivation areas within the old borders of the oasis were more and more given up and new fields were cultivated. The intensification of cultivation in these new areas did not, however, lead to the self-sufficiency of the oasis inhabitants. ${ }^{85}$ The developments influenced the structure of the oasis, which had always been characterised by clear 


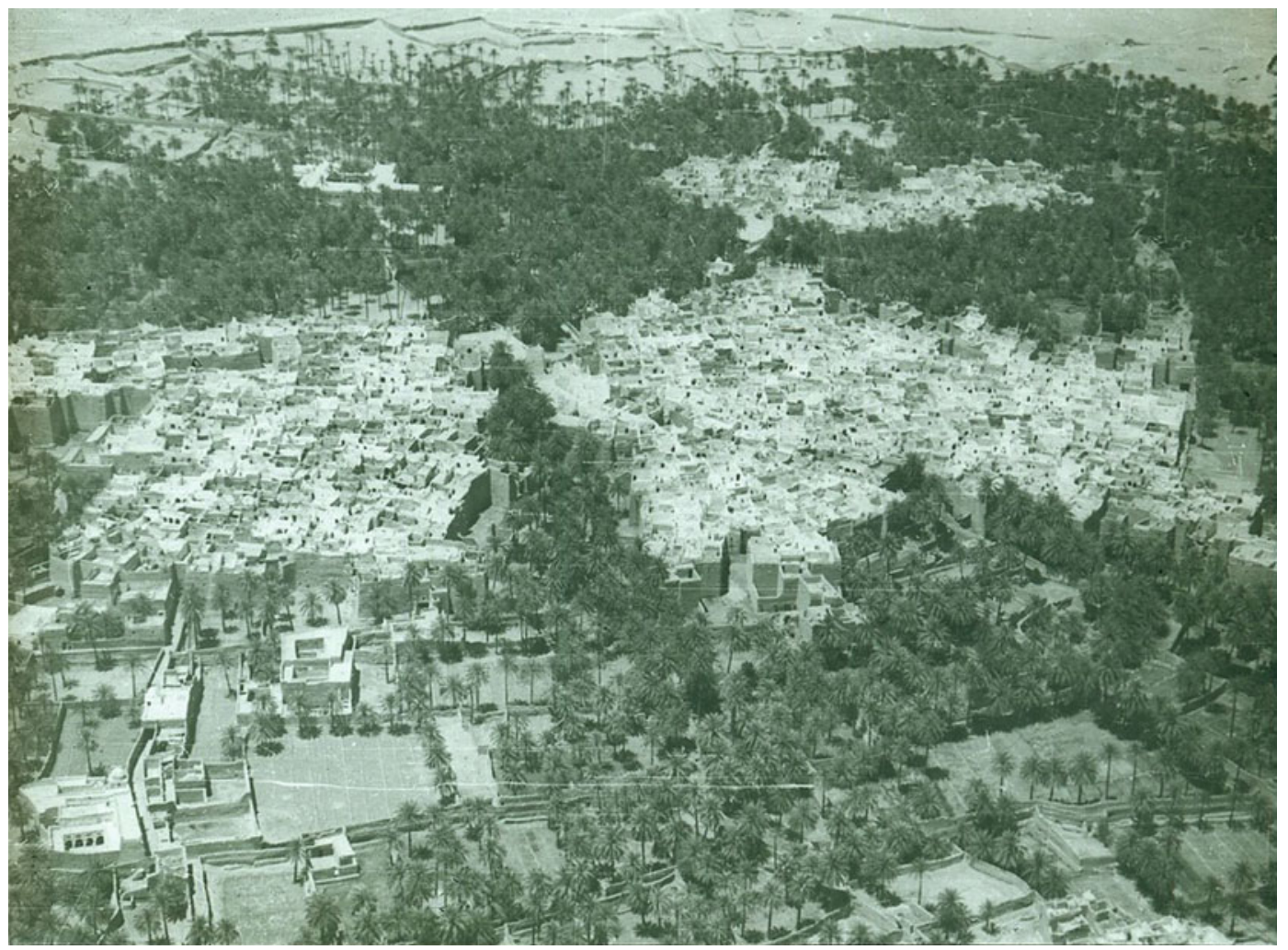

Fig. 6.41 The oasis town of Ghadamis is surrounded by a ring of date palms. The areal photograph of Ghadamis was made during the Italian colonial period

social differentiation. The social structure of many oases underwent a change through the abolition of slavery. New ways of earning a living became apparent, which prompted former slaves to leave the oases. Now farmhands and tenants gained access to education for their children. For themselves, they found rather better paid work, for example in the oil industry. Whilst these groups profited from wide-reaching social and economic changes, nomads found it hard to adapt to the upheavals because of their mentality. The result was the social decline of this group. ${ }^{86}$

\subsubsection{Ghadamis-A Border Town in a Border Triangle}

Today, about 7000 inhabitants of the oasis - primarily Berbers and Tuaregs-live in the new town with modern new-build areas, streets, schools and social facilities, which were built outside the old town by the government in the late 1970s. Many inhabitants return to the old town in the summer as the architecture here offers better protection from the heat. Furthermore, many Ghadamis people try to preserve the apartments and gardens of their forefathers.

Today Ghadamis is a border town in the triangle of Libya, Tunisia and Algeria. The inhabitants of the town make their living primarily for working as state officials and rather less from agriculture. Between the years 2006 and 2010, in the course of al Gaddafi's policy of openness, the Ghadamis people had attempted to build up a new economic basis for their town-tourism. Countless travel agencies were established. A circumstance that was very helpful for its marketing was that in 1986 the walled centre of the old town was given the title of UNESCO World Heritage Site. This decision was based among other things on the long tradition of settlement in this place. Ghadamis, whose heyday of trans-Saharan trade had come to an end and could not compensate for the shortfall in its economic base, could only profit from tourism. Tourism brought travellers to the town again and with them recovery and new job opportunities. ${ }^{87}$ This promising development, however, was halted by the end of the al Gaddafi regime.

\subsection{Mizdah-Important Crossroads in Western Libya}

\section{Salih al-Mahdi Khalifa}

Mizdah is situated $85 \mathrm{~km}$ to the south of Gharyan. It is considered to be the first desert centre to the south of the western mountain, connecting al-Qibla, al-Hammada and the Fezzan with the civilizational areas on the Mediterranean coast. The city is located on one of the bifurcations of the Suf al-Jin valley, at the intersection of latitude $31.25^{\circ}$ north with longitude $13.05^{\circ}$ east, and at a height of about $400 \mathrm{~m}$ above sea level. 


\subsubsection{Divided City}

Throughout history, the city is divided into two populated conglomerations, namely Upper Mizdah, the biggest of the two, and Lower Mizdah which is situated to the east of Upper Mizdah. Since ancient times, the city, with its two conglomerations, constituted an intersection point for two Roman caravan routes. To the south of Mizdah, and along the main road towards the Fezzan, there is a chain of small fortresses and castles that had been erected with the aim of defending the caravan routes. This indicates that Mizdah, since ancient times, was one of the important dynamic areas which linked the coastal cities to the southern regions. Moreover, around the city, one comes across the remains of an old bastion with openings in its higher sections, along with three semi-conical towers called "qasaba". The so-called qasaba of the Gazelle is $14 \mathrm{~m}$ high and is situated to the far north; the qasaba of Umar Belhaj is seven metres high, whereas the one called Qasabat Hnesh is nine metres high and is situated in the far south. These towers serve to control and defend the city. ${ }^{88}$

\subsubsection{Crossroads of the Main Trade Caravans}

Mizdah owes its importance to the fact that it is located at the intersection of a great number of caravan routes directed south, towards central Africa, across the Fezzan, Murzuq and Ghat regions. One of the most important routes starts in Tripoli and proceeds towards al-Kidwa (al Aziziyah), Bughilan, Awsaden, Ain Ghan, Gharyan, Birtsha, Mizdah, Wadi Tajeflet, abounding in the plant genista raetam, which is a desert shrub having small white flowers. The route proceeds via Umm as-Sabt, the Taskija valley and the Zamzam valley, which is rich in pasture, to Mudallal, renowned for its amaranths, and Busif, famous for its pasture, to Bir at-Tabuniya, an important meeting point on the caravan routes. From here, numerous paths branch out in the direction of the Fezzan oases, or the Algerian desert cities, and from there towards West Africa. From Bir at-Tabuniya, the route proceeds towards Bir at-Tayih, and from there towards Bir al-Hasi, whose depth does not exceed five feet. The route continues until it reaches Wanzrik, in the Wadi ash-Shati (Fig. 6.42).

There are also two routes from Tripoli to Murzuq, the shortest of which proceeds south of Gharyan in the direction of Mizdah, and then, it branches out into two routes. The first route stretches out towards the west, whereas the second one, the longest, goes towards the east. This was considered the usual route taken by caravans and by the postal service, in view of the availability of water resources in well-organised stations. This route also offered adequate means of rest, as well as numerous secure population centres, such as Bani Walid, Abu Nujaym, Soknahh, al Fugaha, and the oases and cities of the Fezzan. The trip usually lasted thirty days, whereas for the western route one needed a little more than twenty days. However, the caravans did opt for the latter route due to the lack of cities and villages for long distances along the route, as well as because of the lack of water resources. In view of the availability of many pastures in the nearby valleys, such as Suf al-Jin, Wamis, Mirsit, Imran valley, al-Jalila, al-Baqla and Dreydar valley, especially during spring and autumn, the caravans tended to direct themselves towards such places which abound in grass, tamarisk, acacia and terebinth trees, as well as sesame, which constituted the nutrition of the caravans' camels. ${ }^{89}$

A number of minor routes branch out from these two major ones, the most important of which being:

- The Zintan, Aqla Jifrat, Mizdah route.

- The Qsar Yefren, Mizdah route: The route passes through Yefren, ar-Rumiyya, Mawqa al-Hosh, Qsar Wamis, as-Shaqiqa. Here, one finds seven wells abounding in sweet water and whose depth is only one metre.

- The Mizdah, Fasanu waterwheels' route passing by Dirj and Ghadamis: The water resources on the route consist of wells, reservoirs and natural marshes. These are sometimes situated wide apart from each other and are known only to the most experienced. Along the caravan route, one comes across the Wadi al-Khayl, the an-Nasira well, a series of swamps marshes with salty waters, the most important of which being the Atwa marsh and the Atwa depression. In their vicinity, there is a well of sweet water three metres deep.

- The Nalut route which passes by ar-Rajil waterwheel, al-Kilab well, Fasanu waterwheels and Mizdah.

- The Mizdah route, via Nasma well, passing by the al-Mizraq spring and Sqafnana well ceeds via Umm as-Sabt, the Taskija valley and the Zamzam valley, which is rich in pasture, to Mudallal, renowned for its amaranths, and Busif, famous for its pasture, to Wadi Tabunia, an important meeting point on the caravan routes (see from Tripoli to Mizdah). From here, numerous paths branch out in the direction of the Fezzan oases, or the Algerian desert cities, and from there towards West Africa. From Wadi Tabunia, the route proceeds towards Bir at-Tayih, and from there towards Bir al-Hasi, whose depth does not exceed five feet. The route continues until it reaches Wanzrik, in the Wadi ash-Shati (Fig. 6.43).

There are also two routes from Tripoli to Murzuq, the shortest of which proceeds south of Gharyan in the direction of Mizdah, and then, it branches out into two routes. The first route stretches out towards the west, whereas the second one, the longest, goes towards the east. This was considered the 


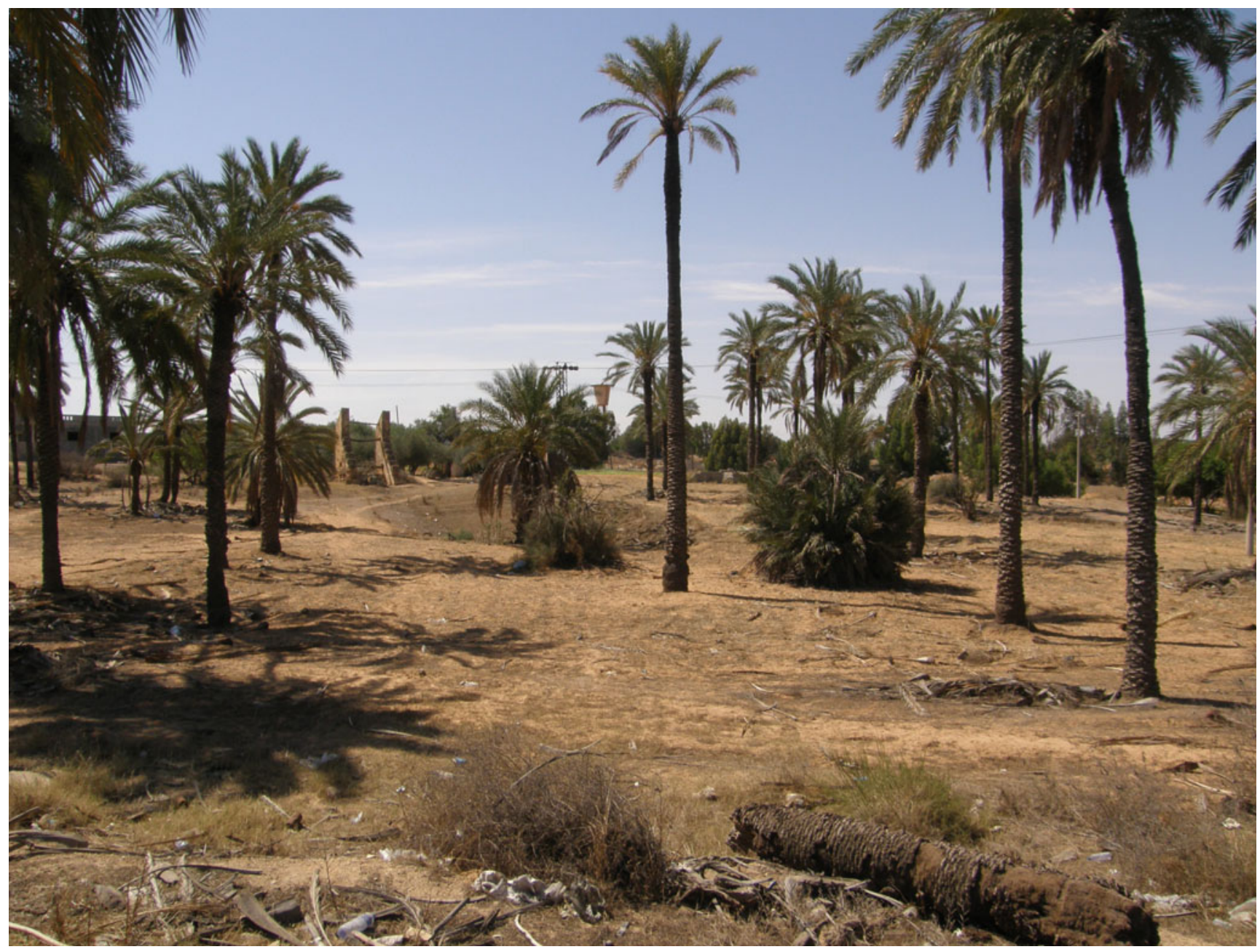

Fig. 6.42 Mizdah was probably established in the mid-second century BC and was called Musti Come by the Romans. The region around Mizdah is penetrated by a large number of valleys. Inscriptions on rock walls found in Wadi al-Khail, south-east of the oasis, show that the region had fertile grazing land for thousands of years

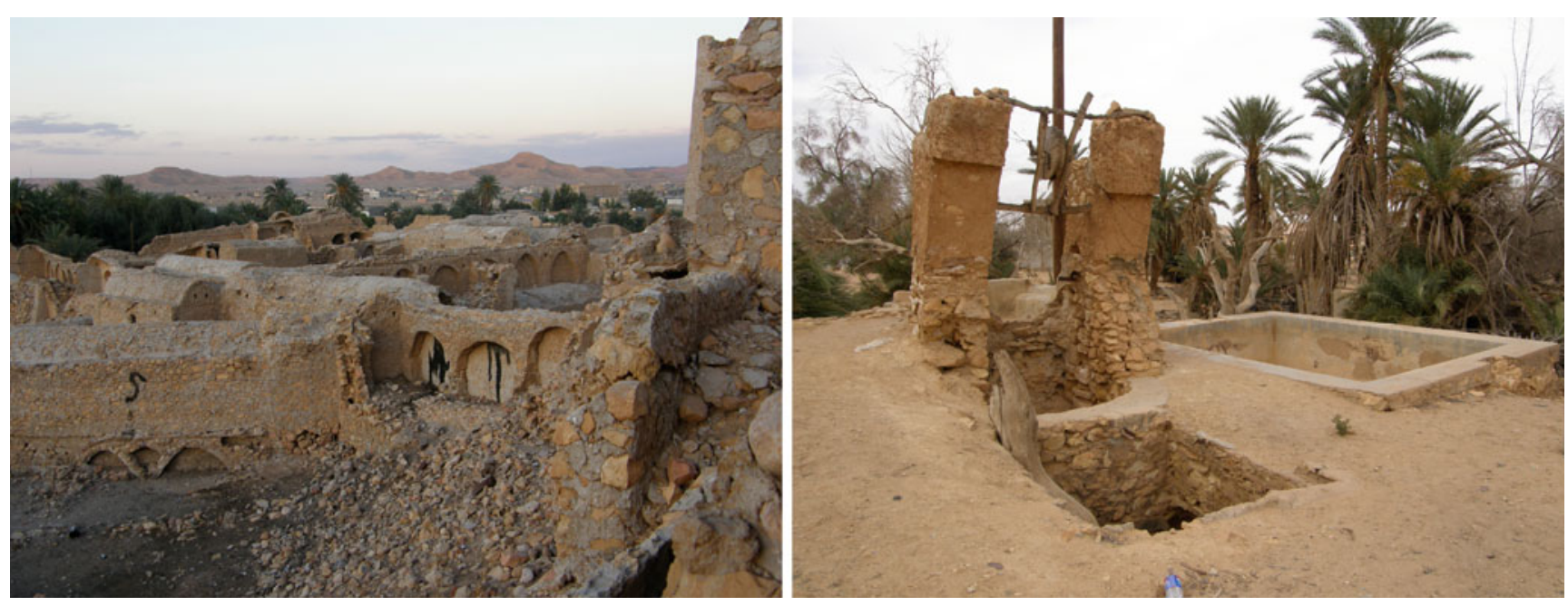

Fig. 6.43 Mizdah has some old houses that mark the old town (photograph on left). A well situated right on the edge of the old city 


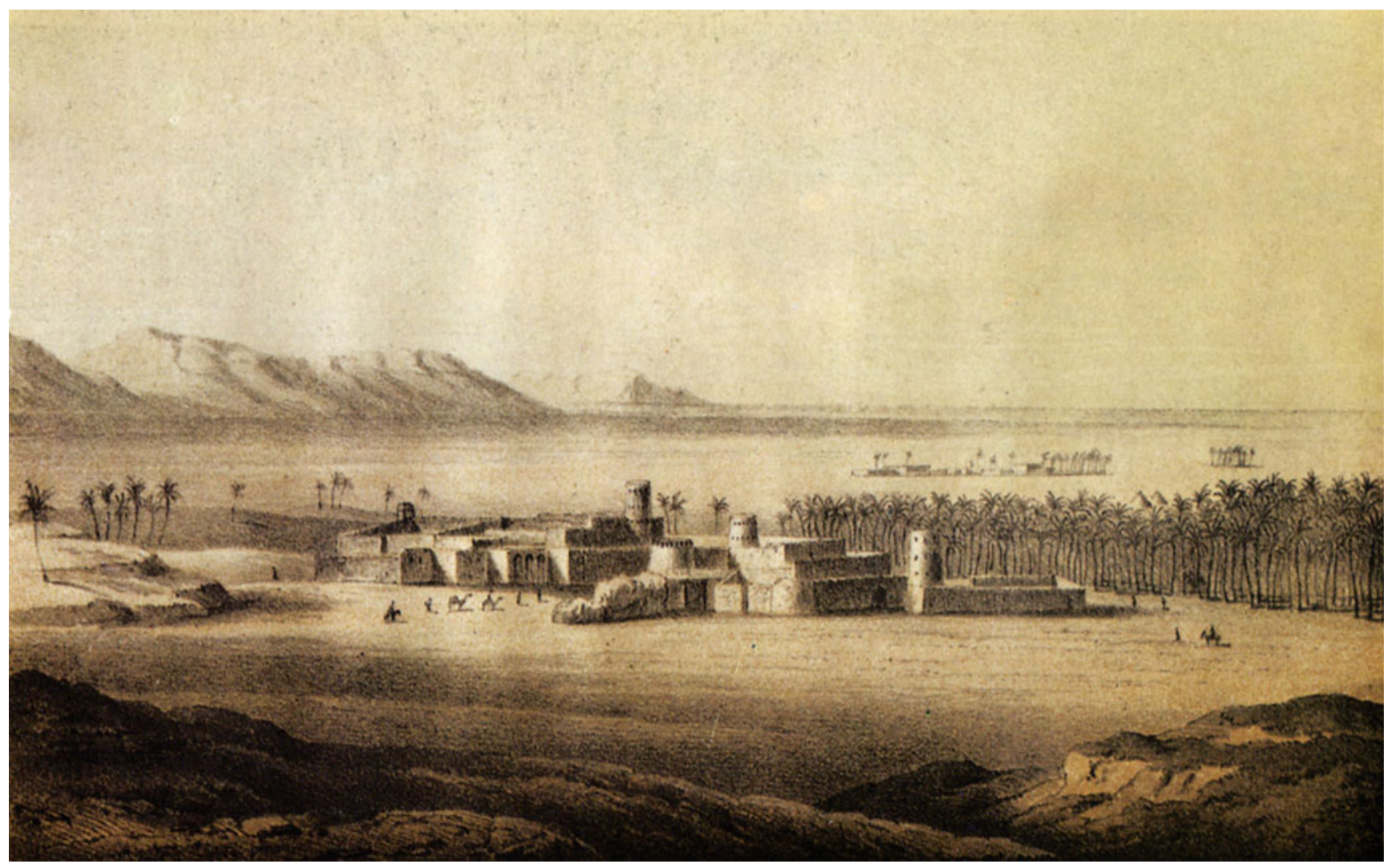

Fig. 6.44 German traveller Heinrich Barth stayed in Mizdah for some time on his way to the south (Barth 1977, 198)

usual route taken by the caravans and by the postal service, given the availability of water resources in well-organised stations. This route also offered adequate means of rest, as well as numerous settlements, such as Bani Walid, Abu Nujaym, Soknah, al Fugaha and the oases of the Fezzan. The trip usually lasted thirty days, whereas for the western route one needed a little more than twenty days. However, the caravans did not opt for the latter route due to the lack of cities and villages, as well as because of the lack of water resources. In view of the availability of many pastures in the nearby valleys, such as Suf al-Jin, Wamis, Mirsit, Imran valley, al-Jalila, al-Baqla and Dreydar valley, especially during spring and autumn, the caravans tended to direct themselves towards such places which were abound in grass, tamarisk, acacia and terebinth trees, as well as sesame, which constituted the nutrition of the caravans' camels (Fig. 6.44). ${ }^{90}$

\subsection{Al Qaryah-Southern Outpost of the Roman Empire}

\section{Said Hamid}

Al Qaryah al-Gharbiya, or the Western Village, is situated in the red rocky desert, about $310 \mathrm{~km}$ southeast of Tripoli. It is located at latitude $30.20^{\circ}$ north and longitude $13.45^{\circ}$ east.

\subsubsection{Southern Outpost}

The importance of al Qaryah al-Gharbiya can be dated back to Roman times. During the reign of Septimus Severus, in the year 201, a fortress was built there to protect the Tripolitanian borderline. Moreover, the fortress enabled the Romans to extend their rule over the southern regions, thus penetrating the desert shield formed by the Libyan tribes. The Romans were able to control the commercial route that linked Tripoli to the city of Garama (Jarmah), whose people controlled the desert caravan trade. One may state that the western village was like a bridge that linked the economy of the Mediterranean region, on the one hand, and the economies of the oases, on the other hand.

The western village witnessed the excavation of some old archaeological sites located between the eastern depressions, the area of the fortress and the present-day oasis. These sites spread over an area of about six to ten hectares, and they pointed towards considerable human habitation. Such habitation was facilitated by the availability of water and date palm groves. The western village owed its importance to its location on the caravan trade routes linking Tripoli to the sub-Saharan countries. Trade caravans used to carry merchandise from the Mediterranean regions towards the south, proceeding from Tripoli towards al Aziziyah, Gharyan, Mizdah, until they reached al Qaryah. From this 

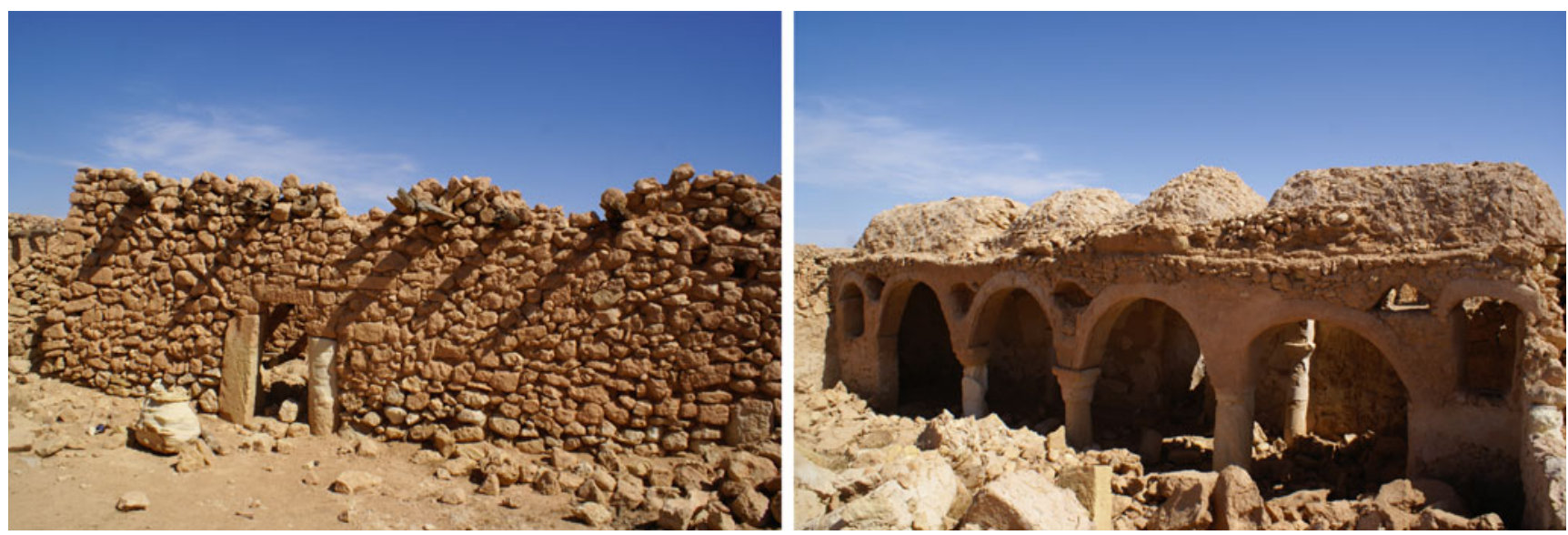

Fig. 6.45 Remains of a building and a mosque in al Qaryah al-Gharbiya

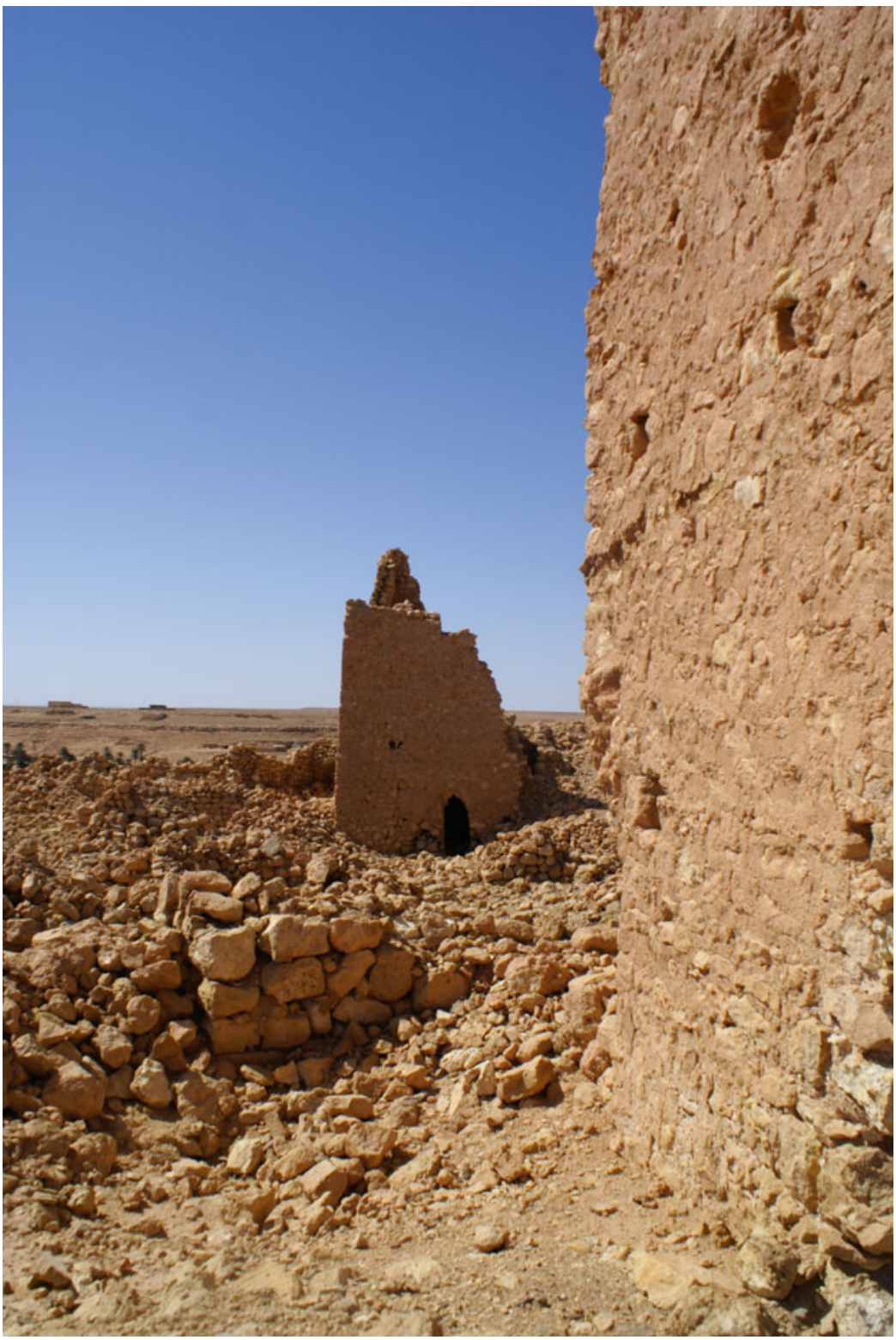

Fig. 6.46 During Antiquity and the Middle Ages, al Qaryah al-Gharbiya had been a transit centre 
village, the caravans would leave for Tamzawa and, at this point, two sub-routes branched out, one towards the west, to Idri, and then southwards towards Jarmah, Awbari, Ghat, and from there to Timbuktu or to Kano. The second sub-route, in turn, branched out in two other sub-routes. The first went towards Sabha and then south-eastwards in the direction of Zawilah, Tmissah, al Kufrah, al Awaynat and al Fashir, whereas the second route left Sabha towards the south-west, to Jarmah and Tasawah. From Tasawah, two routes branched out, one proceeding to Ghat, the other to Murzuq and Taraghin. At this point, the route headed southwards to al Qatrun, Madrusah, Tajarhi, Kuwar and Kuka. In Roman times, there was a route that served military purposes. It linked Abu Njim, al Qaryah al-Gharbiya and Ghadamis. During the third century, three Roman fortresses were built in Ghadamis. These constituted the southern border of the area subjected to Roman control. The road between the western village and Ghadamis was about $412 \mathrm{~km}$ long.

During Antiquity and the Middle Ages, al Qaryah had been a transit centre where caravan traders would stop for their rest and for the replenishment of their water supplies from the available wells and water sources. Moreover, the traders also procured dates and cereals, particularly during seasons of abundant rainfall. The village gradually declined as well as its population, and during the nineteenth century, only a handful of people lived here. According to Barth, the place then was avoided by the caravans (Figs. 6.45 and 6.46)..$^{91}$

\subsection{Adiri-a Transit Station and Meeting Point of Commercial and Pilgrim Caravans}

Najmiya as-Sadeq at-Tellisi and Mansour El Nayedh

The oasis of Adiri is situated in the remote west of Wadi ash Shati, one of the great dry valleys which cross through the Fezzan region. It is about $180 \mathrm{~km}$ away from the city of Sabha. Adiri is located at longitude $27.30^{\circ}$ north and latitude $13.05^{\circ}$ east.

\subsubsection{Transit Station in a Semi-Arid Area}

Geographically, Adiri is situated in a semi-isolated area surrounded by sand dunes on all sides. Idhan Awbari borders Adiri on the west and the south-west, separating it from Wadi al Hayat in the south. In the north, it is bordered by the hills and valleys of the Hasawinah Mountain, whereas in the east it is bordered by Wanzrik and Tmisan. By virtue of its geographical location, Adiri constituted an important strategic centre on the caravan routes directed northwards and southwards. It was also important from the historical and cultural points of view, as confirmed by the remains of castles, mosques and tombs, the construction of some of which goes back to historical periods following the Islamic conquest of the Fezzan region (Figs. 6.47 and 6.48).

Adiri's desert climate is characterised by soaring temperatures in summer and the scarcity in rainfall over winter. During spring, it is exposed to north-westerly and southerly winds laden with dust. These are the famous qibli winds. Adiri owed its commercial and economic importance to the availability of underground waters as well as to the abundance of orchards and date palm trees. Moreover, a great number of wells are scattered around the city and along the roads leading to it. These are shallow wells. Their depths range very often between eight and ten feet. In 1998, it was calculated that there were about twenty wells and fifty springs whose waters are fit both for drinking and for agricultural purposes.

Adiri's main economic activity consists of agriculture. Fresh and dried dates are among the city's most important products, apart from barley, grain, canes, and limited quantities of corn which suffice for the local consumption. Moreover, vegetables are also cultivated in winter and in summer. Today, these include, for example, tomatoes, melons, peppers, onions and garlic. The inhabitants of the area are also engaging themselves in the herding and rearing of camels, goats and sheep.

\subsubsection{Commercial Activity}

Adiri witnessed a thriving commercial and economic activity during the eighteenth and the nineteenth centuries. This was due to the favourable security conditions and stability in the region as well as to the presence of water resources, including running springs and wells situated along the routes leading to Adiri. During this period of time, Adiri witnessed considerable commercial caravan activity; it became an important centre and station on the caravan trail. For this reason, Adiri turned into an important station that supplied caravans with water, fresh and dried dates and other necessary food. By the end of the nineteenth century, the caravan activity declined because of the discovery and adoption of alternative routes. The decline was also due to the expansion of the colonialist movement across the sub-Saharan countries. This development led to most commercial routes being re-routed, favouring rivers and other routes heading towards Western Africa. $^{92}$

Adiri represented a transit station and a meeting point for a number of important commercial caravans as well as pilgrims' caravans hailing from the Arab Maghreb which headed northwards, southwards or eastwards towards the 


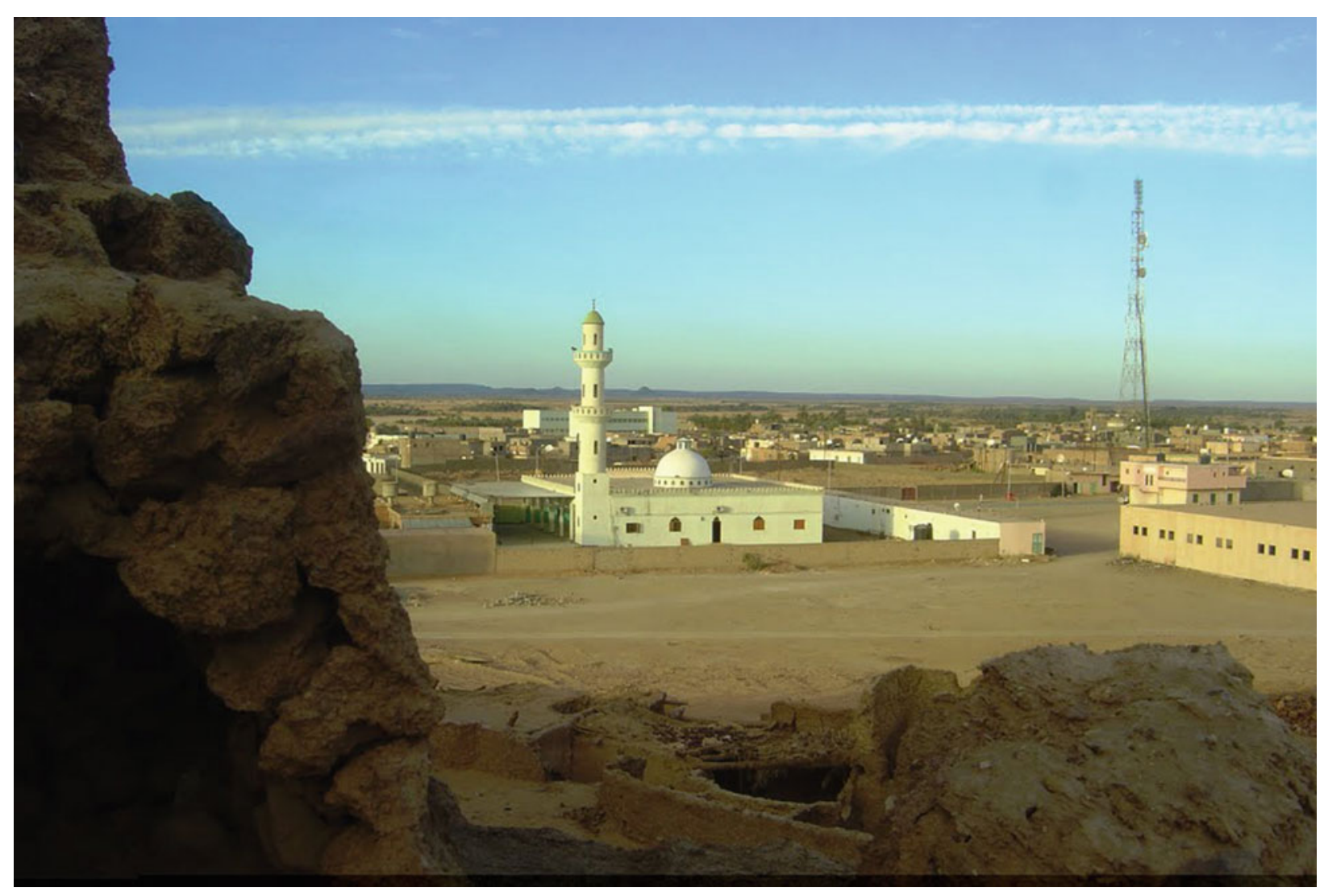

Fig. 6.47 Modern Adiri is a town in the Wadi al Shati district, today home of 4600 people

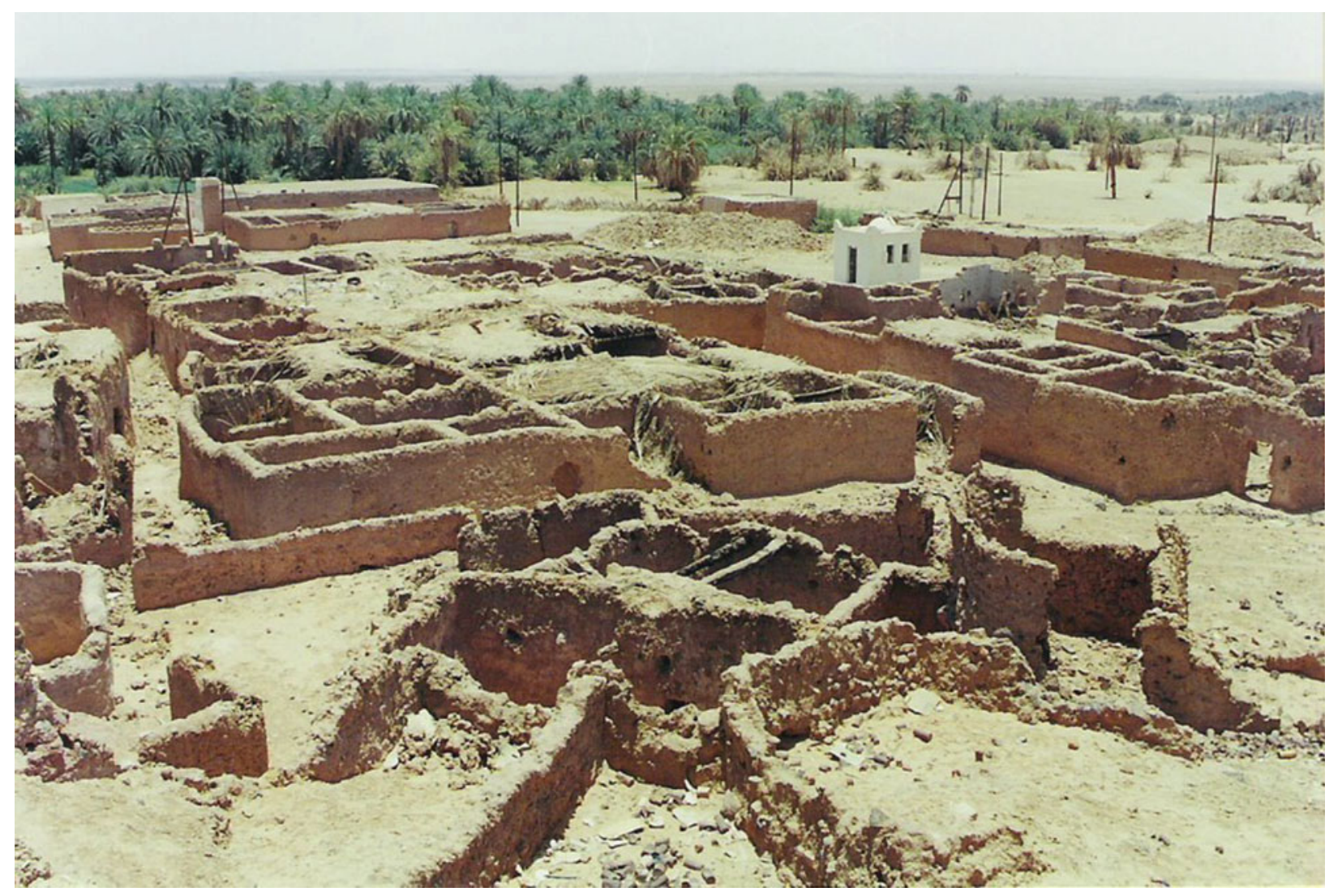

Fig. 6.48 Old town of Adiri was a transit station and meeting point for commercial as well as pilgrims' caravans 
holy places. Among the most important routes, linking Adiri to the Mediterranean Sea and the south, one could mention:

- The route coming from Ghadamis proceeded to Sabha and from there branched out in two directions - the first towards Zawilah, and the second towards Jarmah and Awbari, continuing in the direction of Ghat and West Africa.

- A route also headed out from Adiri towards Jarmah via the sand dunes of Idhan Awbari and from there proceeded to Murzuq, al Qatrun, Tajarhi and thence to central Africa.

- A route left Adiri towards the north via Timzawa and proceeding in the direction of Darj until it reached Tripoli.

- Another route left Adiri towards Ash Shuwayrif. From there, the route branched out in two directions, the first heading towards the cities of the Jufrah depression and then to Sirte and Banghazi, whereas the second proceeded northwards towards al-Qrayyat reaching Mizdah and then Tripoli.

- The desert route which left Tripoli towards Tarhuna and then Bani Walid. At this point, the route intersected with the pilgrims' route at Jufrah. From there, the route proceeded towards Zillah, Awjilah, al al Jaghbub and Siwa, and from there across the Sinai Peninsula towards holy Mecca.

\subsection{Al Fugaha-Isolated Oasis in the Libyan Desert}

\section{Said Hamid}

The al Fugaha oasis is situated to the south of the city of Sirte and north-eastwards of the city of Sabha on the western edge of the great central Haruj volcano and lava field. The oasis is located at latitude $27.50^{\circ}$ north and longitude $16.15^{\circ}$ east.

The al Fugaha oasis (Figs. 6.49 and 6.50) was considered one of the most isolated oases in the Libyan Desert and among the poorest in superficial natural resources. This was due to its extreme climate and its isolation from the great centres of culture and civilisation. In the past, the Arab travellers and geographers did not pay much attention to the village. Most historical and geographical sources do not make any reference to it. The few sources referring to the village simply stated that halfway between Tmissah and Zillah, there was a campsite belonging to the Waddan people, called al Fugaha.

al Fugaha was considered a transit station for some commercial caravans heading north or south. The oasis was linked to a road which started at Sirte and proceeded towards Tagreft and from there towards al Fugaha. Moreover, another road linked Ajdabiya, Maradah and Zillah to al Fugaha. This oasis was also linked to Sirte via the cities within the Jufrah depression, Waddan, Hun and Soknah. The road which linked the oasis of al Fugaha to the southern regions proceeded towards Tmissah, Zawilah and Murzuq or alternatively headed directly from al Fugaha towards Zawilah. From Zawilah, the road branched out in different directions. The first route headed towards al Kufrah, Waw al Kabir and Waw an Namus and from there to Sudan. The second route proceeded from Zawilah towards the south-west in the direction of Majdul, al Qatrun, Tajarhi, Kuwar and Kuka. A third route left Zawilah towards Umm al-Aranib and Taraghin, reaching Murzuq, Tasawah, Jarmah, al Awaynat and Ghat. From Ghat, the road proceeded towards western African cities, such as Kano and Timbuktu. al Fugaha still retains its old archaeological landmarks. In fact, in its vicinity, one comes across the remains of palaces which used to guard the caravans that crossed that region. Towards the end of the nineteenth century, and as a result of

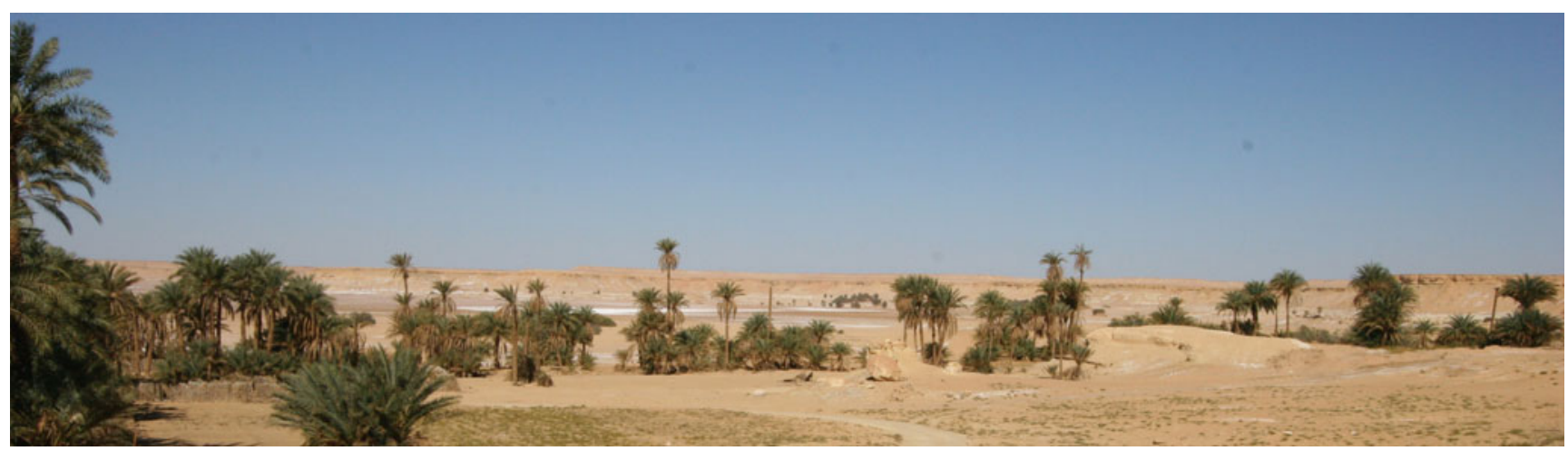

Fig. 6.49 Oasis of al Fugaha is one of the most isolated desert oases. It is inhabited by Berber-speaking locals 


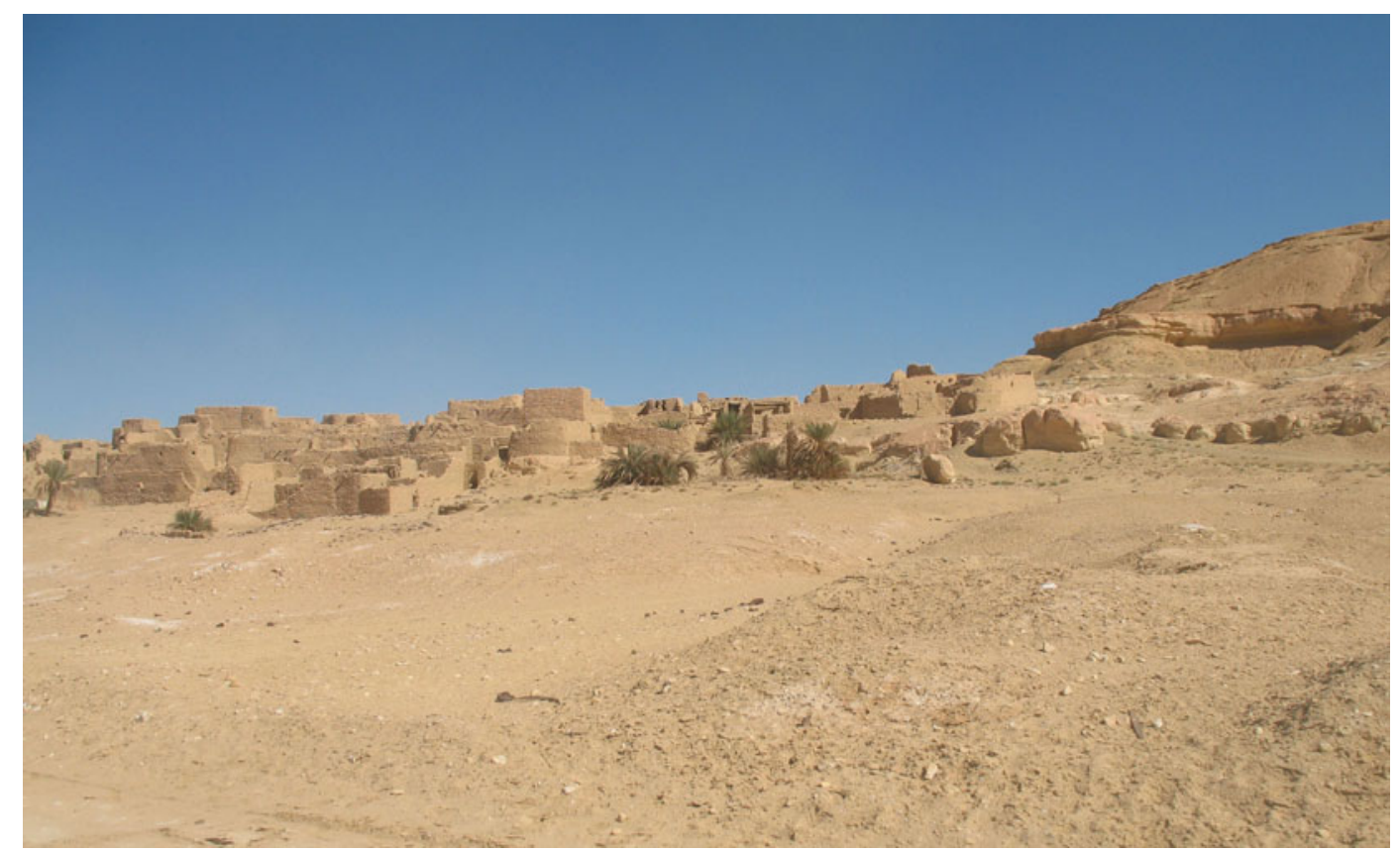

Fig. 6.50 Old town of al Fugaha

the end of caravan trading across the borders, many inhabitants emigrated from the oasis to other regions, particularly to the city of Sabha. ${ }^{93}$

\subsection{Zillah-Oasis of the Palm Trees}

Mansour El Nayedh

Zillah is one of the oases of the Jufrah depression, which is a range of Libyan Desert depressions that stretch from the Ghadamis depression in the west to the al Jaghbub depression in the east. Zillah is located within a conglomeration of cities and oases, at latitude $29^{\circ}$ north and longitude $17.30^{\circ}$ east.

Although geographically, Zillah falls within the subsidiary depression of the great Jufrah, and administratively it belongs to the region consisting of the cities of Hun, Waddan, Soknah and al Fugaha. Externally, the depression resembles a triangle, with its base connecting Waddan and Soknah, whereas its peak coincides with Zillah. This depression is renowned for its fertile lands and the abundance of groundwater, which is close to the surface. Its small farms and the date palm groves extend to areas far away from the city centres and the oases of the region.

In the south, the Zillah partial depression borders with the Harudj Mountains as well as the as-Sawda, al-Qarrat and
as-Sarir region. Westwards, it borders with the Waddan Mountains and the sand dunes region which almost separate it from the Jufrah oases. Northwards, the depression borders with the Tagreft depression, which also includes some highlands, low grounds and the small rocky tables which extend from the west to the east. Eastwards, it borders the sand dunes which almost separate it completely from the oases of Jalu and Awjilah and from the Maradah depression.

In view of its geographical location, Zillah falls within the transitional sector between the southern dry desert region and the climatically moderate coastal regions in the north. This area, which is situated within the desert region, with its high temperatures in summer and cold weather in winter, is characterised by small amounts of rainfall in winter. In fact, the yearly rainfall does not exceed $50 \mathrm{~mm}$, and therefore, life in the oasis depends completely on the groundwater, which is at a depth quite close to the surface, and on its sandy, limy desert soil which formed as a result of the harsh natural and climatic conditions. At times, the soil manifests itself in different forms such as sand dunes, gravelly ground or desert terrain.

\subsubsection{Transit Centre in the Middle Ages}

The geographical and historical writers such as al Idrisi, al Himyari or Abu al-Fida refer to the area as Zala, whereas al 
Bakri, in his Kitab al-istibsar, refers to it as Zalla. Later, the name became Zillah. Many Arab geographers and travellers of the Middle Ages described it as a city with thriving markets, a flourishing trade and a valorous, generous population. In the year 1862, the German traveller Rohlfs, who had visited the oasis several times, estimated the population of Zillah at approximately 1200 persons.

According to popular tradition, the ancestors of the present inhabitants reached Zillah about one thousand years ago. Before the Islamic conquest, the area was inhabited by the Mzata tribes. These were the original inhabitants who had resided in the area and had adapted themselves to the climatic conditions prevalent at that time, making use of the fertile lands of the oasis to secure their agricultural needs.

The Arab Muslim leader Uqba ibn Nafi took over Zillah during his campaign to conquer Zawilah, in the year 643 . From then onwards, the Arabic influence prevailed and the inhabitants started speaking the Arabic language. During the twelfth century, the oasis acquired its commercial importance, becoming one of the transit centres of the desert trade.
During the Ottoman period, the region administratively formed part of the Fezzan, in view of its dependency upon Jufrah. Subsequently, after the abolition of the federal system, it became dependent upon the province of Jufrah, within the Fezzan region, comprising five districts: Zillah, Hun, Waddan, Soknah and al Fugaha.

\subsubsection{Economic Life}

For a long time, agriculture was the foundation of the economy of the oasis. Zillah was renowned for rich and arable land as well as for the big variety and excellent quality of its dates. In addition to dates, products such as corn of the qafuli type, maize, barley, wheat, tomatoes, onions, melons, cabbages and legumes were cultivated in the oasis. These agricultural products were mostly produced for local consumption. Whenever there was a surplus of produce, it would be given away to the passing caravans. In fact, Zillah owed its importance to its extensive groves of date palms. In

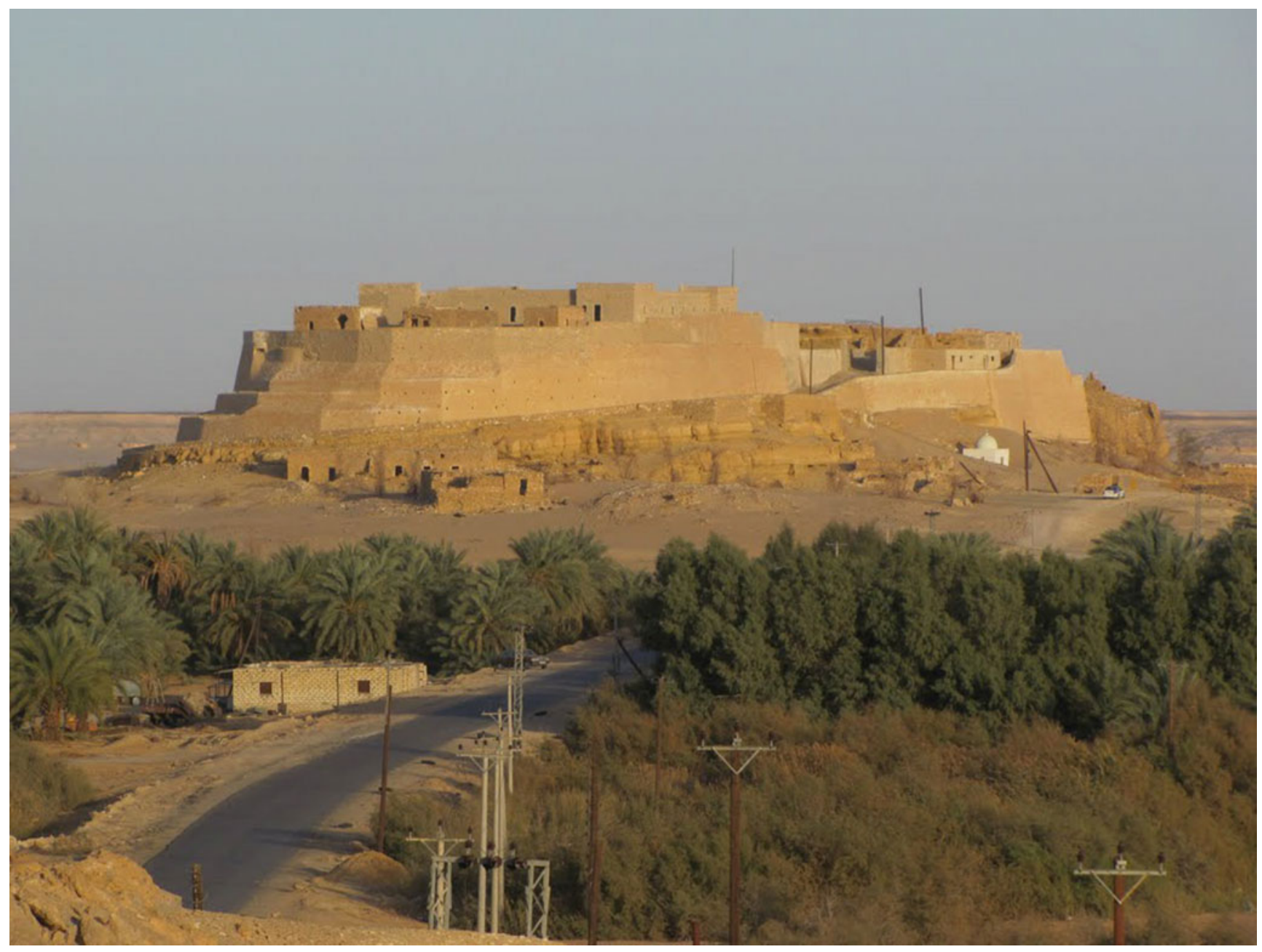

Fig. 6.51 Turkish fort of Zillah towers above the area 
1906, Abd al-Qadir Jami estimated that there were 120,000 date palms. This figure was later confirmed by Jamal ad-Din ad Dinasuri in his book The Geography of the Fezzan. The date palms spread out beyond the oasis, covering great areas which may reach out as far as $50 \mathrm{~km}$ to the surrounding area.

As mentioned before, Zillah was located on the main caravan routes from Sirte and Banghazi. The caravans used to be loaded with grain, barley and traded products to be exchanged with the inhabitants and the merchants of the oasis. Usually, the exchange was done on the basis of barter, especially in the case of dates, which were available in large quantities in addition to locally manufactured products made of palm leaves, wool and fur. But some merchants paid with money. Among the currencies in circulation, one could mention the Austrian Riyal which was minted in 1780 and was widespread across North Africa at that time. Zillah's importance was not restricted to the exchange of products between the local inhabitants and the merchants, but it was also considered a market and a rest area for travellers. It was a transit station for caravans directed south, towards the Fezzan region and from there to central Africa. It was also a halt for caravans in eastern direction, i.e. towards the oases of Banghazi, al Jaghbub and Egypt, and from there on to the Hijaz. This was called the pilgrimage route. It linked the west with the east, and vice versa. Zillah became famous for its commercial markets which used to be frequented by merchants from nearby areas, who traded and exchanged products and merchandise. The oasis was now and then influenced by adverse climatic and economic conditions, leading to a commercial recession in some seasons, especially in summer, due to the high temperatures.

\subsubsection{Meeting Point of Trade Caravans and Pilgrims}

The oasis of Zillah became very significant due to its strategic location as a passage for pilgrims to and from

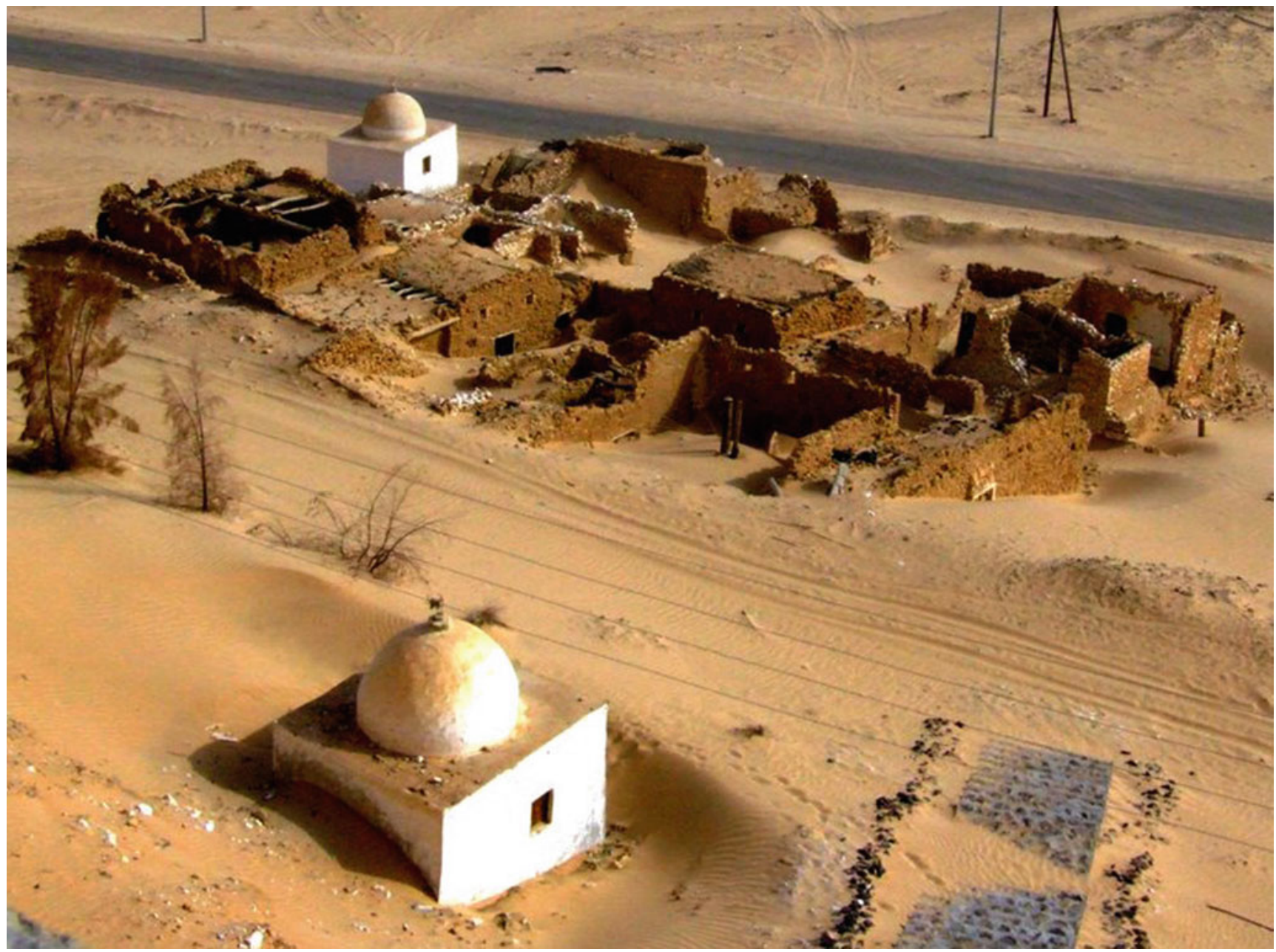

Fig. 6.52 Remains of the old town of Zillah 
Mecca as well as for the trade caravans (Fig. 6.51). The route used to start off at Marrakesh, Algeria and other regions, proceeding via Ghat and Awbari, then to Sabha and north-eastwards towards al Fugaha, until it reached Zillah. From there, the caravans would resume their journey eastwards, towards Banghazi, or north-westwards, towards Sirte. Following the coastal road, the caravans would then proceed towards Egypt and from there to the holy places. On the return journey towards the Arab West, the caravans stopped at Zillah's market to exchange products and merchandise from Egypt. Moreover, the oasis was bound with strong economic, social and intellectual ties with its neighbouring oases, particularly with the Jufrah oases, Maradah, Jalu and Awjilah, renowned for its commercial, economic and religious activity.

Among the most important commercial routes which passed through this region was the so-called middle route which left Tripoli, passing through Tarhuna towards Bani Walid, Abu Nujaym, reaching the Jufrah oases, Waddan, Hun and Soknah. From there, the route proceeded eastwards, towards Zillah, and from there to Maradah, Awjilah and Jalu. At this point, the route proceeded either southwards, towards al Kufrah, and thereafter towards the Sudan, or eastwards, in the direction of Banghazi. The route continued towards Egypt, through Siwa, reaching the Nile Delta and al-Fayyum, and from, there it progressed towards the holy lands. Zillah benefitted from some pastures, seasonal rivers and wells of potable water. They secured enough water supplies for men and camels along the routes linking the various neighbouring cities and villages. In the east of the oasis, on the route towards Awjilah, the so-called Rakb well was located. This was one of the oldest wells in the region, characterised by the abundance and the sweetness of its potable waters. There was also the so-called Sabil well, situated north of Awjilah. This did not fall under a monopoly and was available to everybody. The caravans had drawn much benefit from this well, satisfying their own needs and those of their animals. Moreover, there were other wells in the middle of the oasis upon which the inhabitants of the oasis officially depended for their own personal use and for their agricultural needs.

The founding and development of the city of Murzuq, in the middle of the sixteenth century, coupled with the change in the desert route which went through Jufrah towards Abu Nujaym and Bani Walid to Tripoli, led to an economic decline in the Zillah oasis and in its commercial significance (Fig. 6.52)..$^{94}$

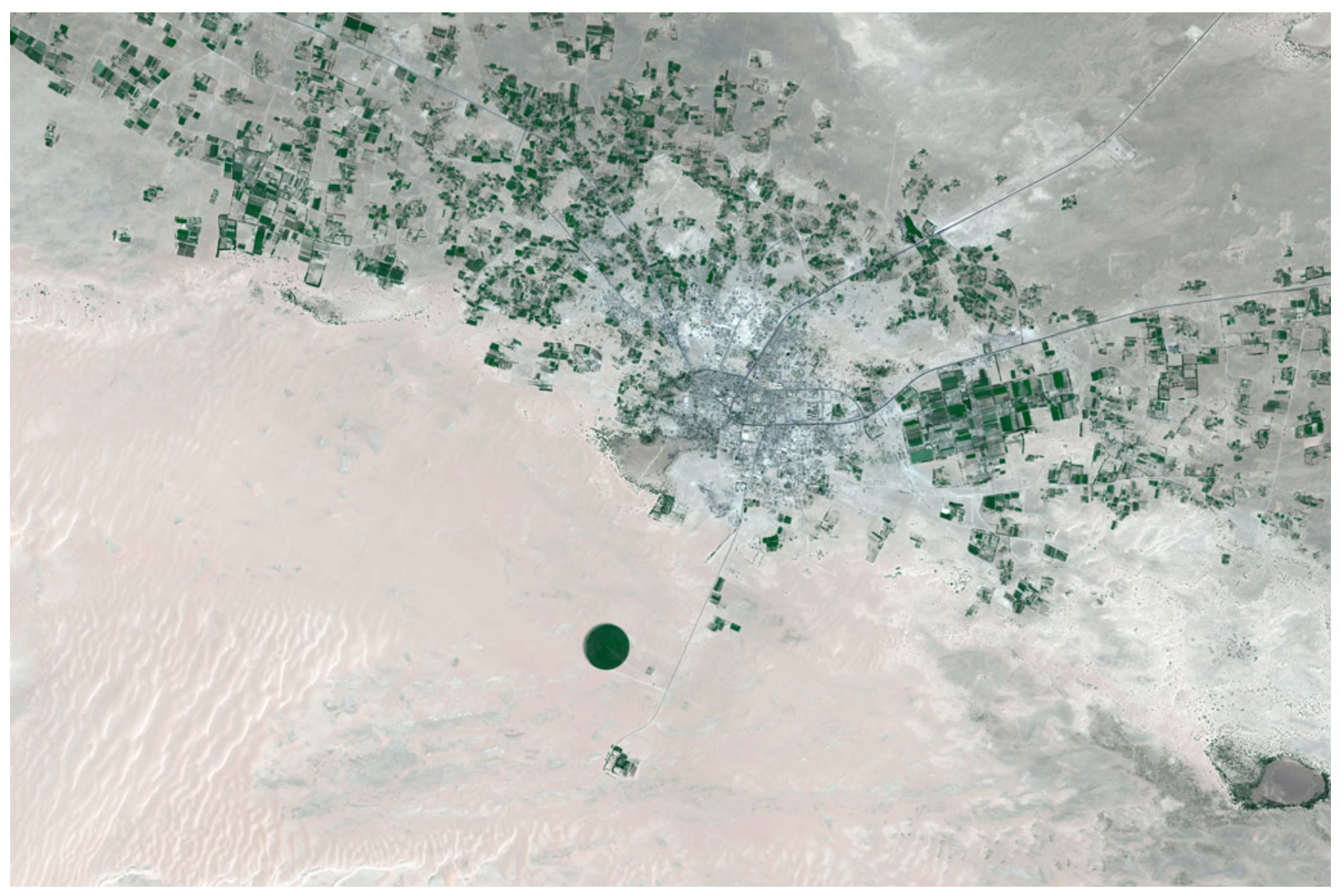

Fig. 6.53 Quickbird image of Murzuq: in the end of the sixteenth century, the oasis gained more importance than Ghadamis or Ghat 


\subsection{Murzuq-Historic Heart of the Fezzan}

Jacqueline Passon, Klaus Braun and Joschua Metzger

Murzuq is an oasis town and the capital of the Murzuq District in the Fezzan region of south-west Libya. It lies on the northern edge of the Murzuq desert, an extremely arid region of ergs or great sand dunes which is part of the greater Sahara Desert.

Murzuq - only a few towns in the Sahara have a name with such a ring to it. As the historical centre of the Fezzan region, trade hub and most significant slave market of the Sahara, it was well-known far beyond the borders of Africa (Fig. 6.53).

Already in the fourteenth century, Murzuq had established itself as the centre of Fezzan and retained this position until well into the nineteenth century. The town hosted the headquarters of the local authorities. Its significance, however, was based on its function as a mid-point of trans-Saharan trade. Many trade routes crossed here, linking together sub-Saharan Africa and the Mediterranean, such as the famous Bornu Road running between Tripoli and Lake Chad. The most important "goods" were black slaves, who made up $90 \%$ of sales. The best of times, however, lie well in the past of this legendary caravan town. The ban on slave trading and recurrent malaria epidemics caused by the salt marshes near the town led the way into insignificance. Today, the good times are rarely remembered: the kasbah, situated in the north-west of town, and the remains of the once famous women's market can only bear insufficient witness to the former significance of the place.

Pioneers of African exploration like Friedrich Hornemann, Gustav Nachtigal, Heinrich Barth, Gerhard Rohlfs and James Richardson made stopovers many times at the oasis and left to posterity their reports on the town.

\subsubsection{Murzuq-The Old Capital of Fezzan}

In antiquity, Murzuq belonged to the territory of the Garamantes, and its centre Garama was $60 \mathrm{~km}$ north-east of the oasis. But its roots are lost in the dark past of Fezzan history. Around the year 1310, a pilgrim named Sidi al-Muntasir al-Muhammad is said to have stopped off here on his way to Mecca, where until this time there were only a few huts. Consequently, further settlers came to the place and the stone and mud fort, kasbah, and the town wall were built. The history of Murzuq began, which was to develop into the economic and political centre of the Fezzan. That Murzuq took on this role dates back to the Awlad Muhammad, who brought the Fezzan with its fertile and water-rich oases under their rule. ${ }^{95}$

The founder of the Awlad Muhammad was a sharif from Morocco or Mauritania named Muhammad al-Fasi. It is said that he arrived first in the Fezzan as the leader of a pilgrimage caravan of the west and that he was requested by the local Fezzani rulers to take over political control. This story, true or not, marks the reinvigoration of pilgrim traffic and the slave trade. A decisive role in the founding of the town was presumably played by its situation at a crossroad of a pilgrimage route from Cairo via Audjila and Ghat to Timbuktu and a long-standing trade route between the Mediterranean coast and the African interior. Particularly significant was the fact that this route from Kuwar, a region in modern-day Niger, through Fezzan and Murzuq to Tripoli or to Banghazi, was the most important route for the slave trade. At the start of the sixteenth century, Murzuq arose as a new centre of the trans-Saharan slave trade.

Situated in the middle of the desert, the town developed over the course of time into a trans-Saharan trade hub. The caravan routes, which led from the coast to the African interior, always passed through Murzuq. The caravans from Tripoli toiled through the desert for up to 30 days to travel a good $900 \mathrm{~km}$. A large part of the journey led through a region called Hamadah al Hamra, a barren rocky desert. Here, it was possible to travel for days without finding water. Fezzan, as the settled area in modern-day south-west Libya is called, appeared to travellers as an oasis landscape. The region, whose capital was Murzuq, lays at $26^{\circ}$ of latitude north of the equator and therefore right in the middle of the Sahara. However, fossilised groundwater ensured that the land was fertile enough for meagre agriculture in the gardens of the town. It was sufficient to feed a population, which according to reports in the 1860s was said to have amounted to up to 8000 inhabitants. $^{96}$

At the beginning of the nineteenth century, Murzuq had developed into a significant economic centre in the Sahara. Due to its situation at a hub point of caravan routes, traders from all directions met here. In 1867, Gerhard Rohlfs wrote: "[Fezzan] is a transport station for goods transports from the north, from Tripolitana and Egypt, to the south, to Bornu and the bordering Negro countries, as well as for products coming from Central Africa." $" 97$

Particularly, the slave trade, which was described by all European African explorers who came to Murzuq, and the trading of gold from countries south of the Sahara had made the trade routes through the desert very lucrative. Goods that went through the Fezzan mostly came through Murzuq. The town was primarily a transport station. In 1857 , the scholar Heinrich Barth wrote that the traders offering their wares at the Murzuq bazaar would take most of their earnings back with them to their hometowns, e.g. Ghadamis. ${ }^{98}$ The slave trade made up the overwhelming majority of the income of the town - and the dignitaries of the town profited from the duties. From 1812, Murzuq was in the hands of the Ottoman Empire. The potentates of the town understood how to use its unique location to its advantage. Rohlfs described the 
taxes that were levied on the importing and exporting of individual slaves. This method of making money was not unusual in the oasis towns of the Arab-Islam world. ${ }^{99}$ The "island situation"100 of the oasis offered no alternatives for accommodation or marketplace to the caravans passing through. In this way, the greatest slave market in the Sahara grew up in Murzuq. This was continued here until the middle of the nineteenth century. By the time the slaves reached Murzuq, they already had a 2-month crossing of the desert from Sudan behind them. From Murzuq, some went further to Tripoli or Banghazi, from where they were sold on to Europe and particularly to other parts of the Ottoman Empire. For others, the terminating point of their journey was achieved on reaching the oasis. The Fezzan traders who lived there often owned fields themselves and had a considerable need for workers for laborious cultivation. The same held true for the nomads, who also farmed cultivated areas in the oasis. In the mid-nineteenth century, slavery was banned in the Ottoman Empire. However, the trade in humans was too lucrative for it to stop immediately. The significance of the town was only to fall rapidly at the end of the century as the flow of slaves gradually dried up. ${ }^{101}$

The level of economic development achieved by Murzuq in the second half of the nineteenth century received varying evaluations in the travel reports of the time. Already in 1857 , Barth emphasised that the consequences of stagnating trade through the desert were "quite obvious"102 and Nachtigal confirmed this estimation in 1879, writing that Murzuq was a place that had "long forfeited its significance as a trade location". ${ }^{103}$ In 1867, however, i.e. exactly during the decade in between Rohlfs saw that the economic downturn was at least becoming milder. He claimed that under the Ottoman government more stable times had come, whilst plundering had previously been the order of the day. ${ }^{104}$

The heyday of economic development in Murzuq had certainly already passed around 1850. The town depended on products from the north that could not be manufactured in the desert town. Goods that required a mechanical infrastructure for their manufacture were particularly difficult to produce in Murzuq. Nachtigal listed the goods which had been offered by traders from Europe and the Ottoman Empire: matches, cigarette papers, Turkish tobacco, confectionery, coffee sachets, cookware, bowls, Dutch cheese, pipe bowls, razors, needles, hand mirrors, scissors, knives, jewellery, bracelets, necklaces, fabrics, etc. ${ }^{105}$ Meanwhile, the demand from the north for slaves and gold decreased throughout the nineteenth century. The demand for gold in Europe was increasingly met by gold from South America. In the course of the nineteenth century, the ban on slave trading gradually prevailed even in the Ottoman regions. However, at the time of the three African explorers, Barth, Rohlfs and Nachtigal, the trade still represented an important factor. $^{106}$ Nachtigal offers a good illustration of the connection described here: "In Fezzan northern goods flowed together from Tunisia, Tripoli and Egypt, going into the landscape of the desert and the Negro lands, where the products of these countries became stockpiled. Throughout centuries so much gold had been brought to Fezzan from Timbuktu from the regions of upper Niger that until the beginning of this century the mitqual of gold here was only a fraction of the current value. Only as the gold supplies ran out were the Austrian and Spanish Taler introduced (...). From the Hausa countries came [various goods and] the most profitable and widespread commodity: slaves. (...) The old people of Fezzan still get lively when they talk of the times of their youth, when throughout the year the great pilgrim caravans came laden with gold from Timbuktu (...) and when several times a year the trade caravans to central Sudan passed through and were a thousand fold stronger on their return. (...) Bad trading relationships (...) the creation of new distribution channels and the weakening of the slave trade had the consequence of a sad regression."107

The overall turnover of Murzuq in the mid-nineteenth century was estimated by the African explorer Heinrich Barth at 100,000 Austrian Taler, where "seven eighths (...) came from the slave trade". 108

\subsubsection{Town View and Inhabitants Since $\mathbf{1 8 5 0}$}

The travellers of the eighteenth and nineteenth centuries described the oasis in great detail. A lively picture emerges when the reports are taken together. They describe walls and towers surrounding the town and a "castle" found in the middle (Figs. 6.54 and 6.55). That Murzuq was "a very wellformed place with wide streets" was noted as "something highly wonderful in an Arab town". 109 The sometimes very detailed descriptions can be compared with the plans drawn up by Heinrich Barth in 1850 (Fig. 6.56) and Moritz von Beurmann in 1862 (Fig. 6.57). Rohlfs wrote: "The town of Mursuk makes a square comprising two English miles (...). It is surrounded by in places cracked (...) clay-built walls, which (...) are flanked by square towers. (...) A wide street (...) leads in a relatively straight line from west to east through the town (...)". 110

The formation of the town corresponded largely to its economic and political development. Until the time of Italian colonisation, Murzuq was considered to be the "capital of Fezzan" and accordingly housed the seat of the Ottoman Governor, and the kasbah, an old fortress and barracks (kischka) with its associated garrison. The castle still surmounts a hill in the north-west corner of the town (Map (13) (14)(15)). It was built by Muhammad al-Fasi and contained the state offices of the Sultan, his residence and that of his sons. A mosque still adjoins the castle. In the various accounts, the central feature of the town was still said to be 


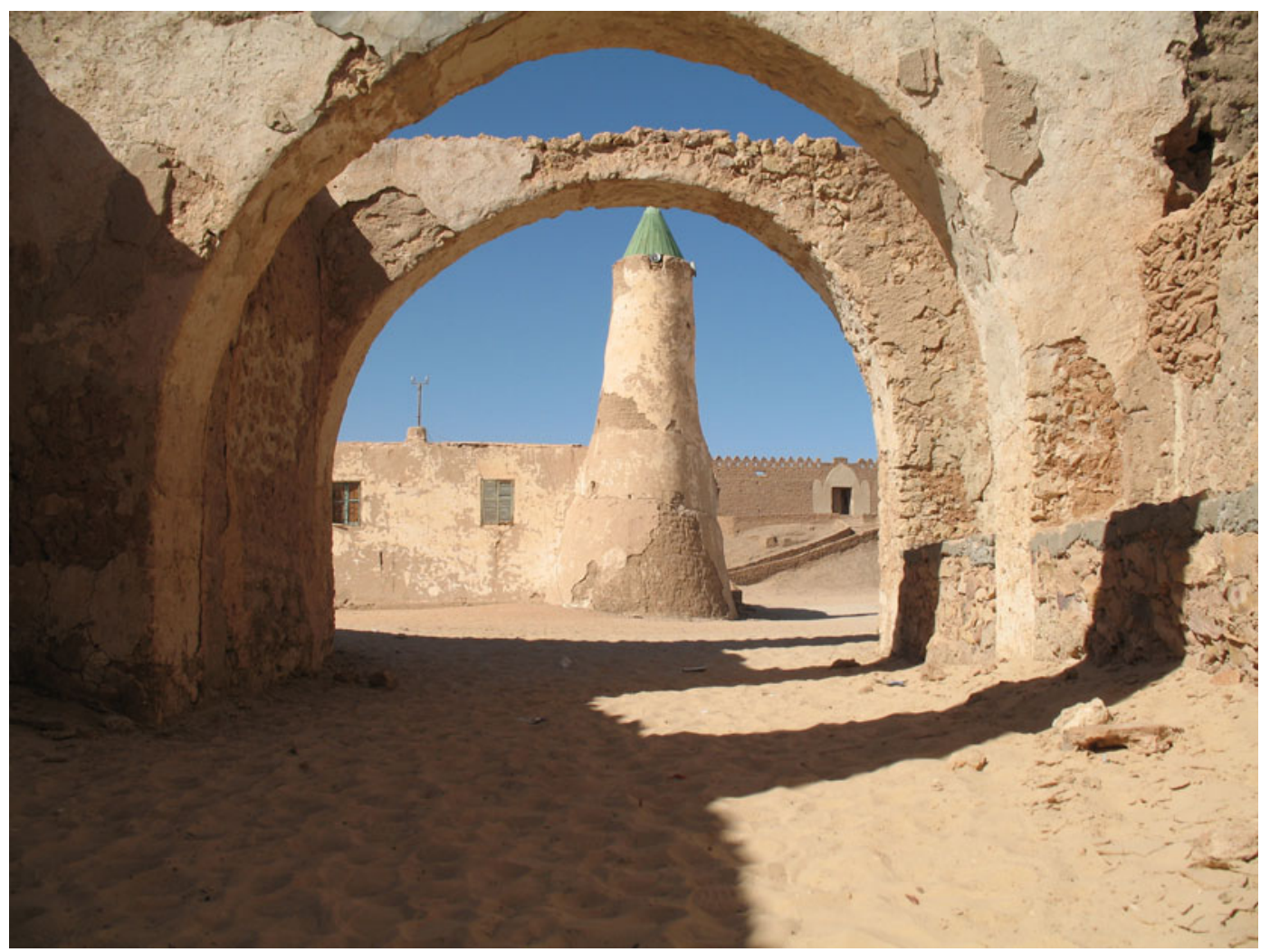

Fig. 6.54 View towards the kasbah of Murzuq

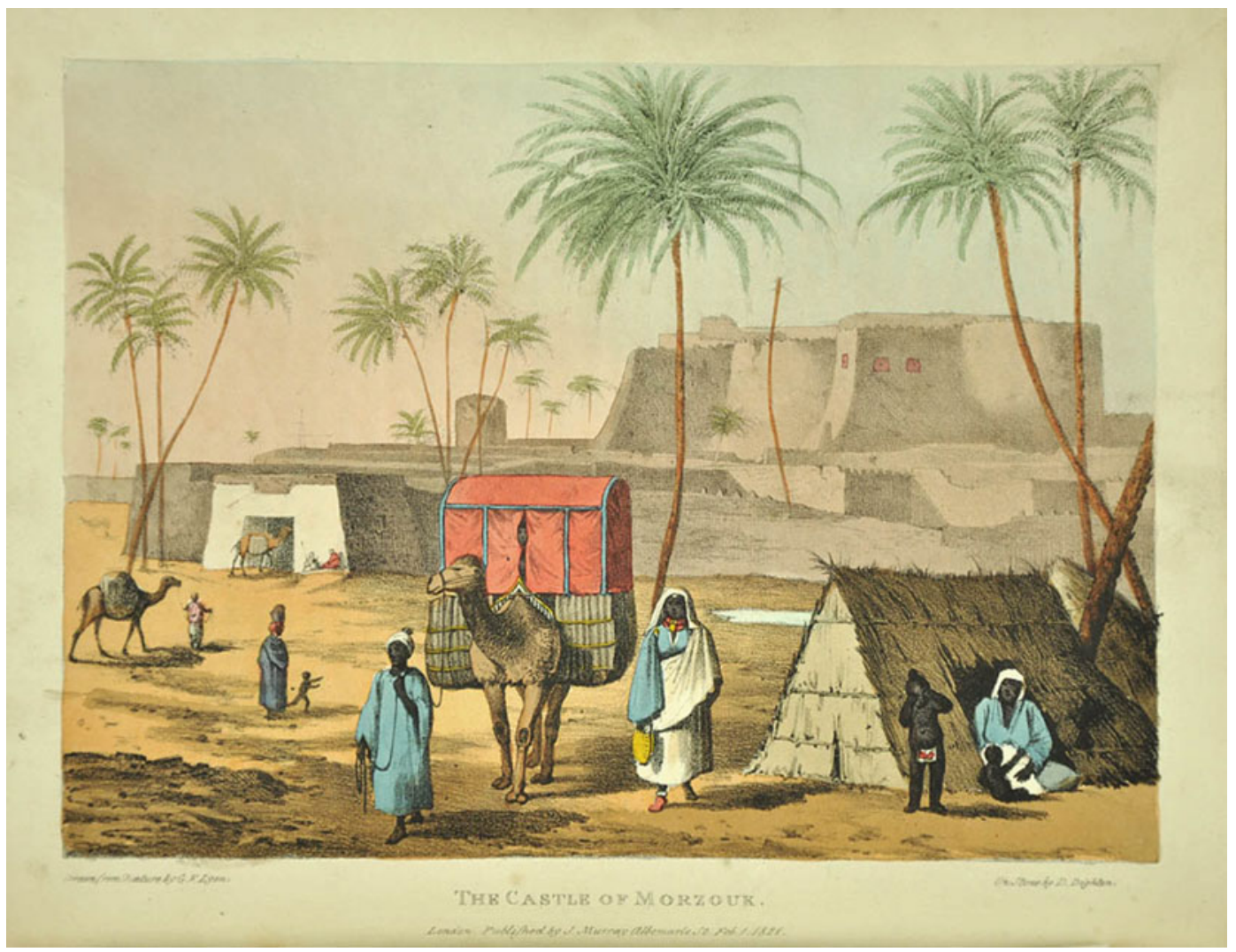

Fig. 6.55 Kasbah as seen by Lyon 


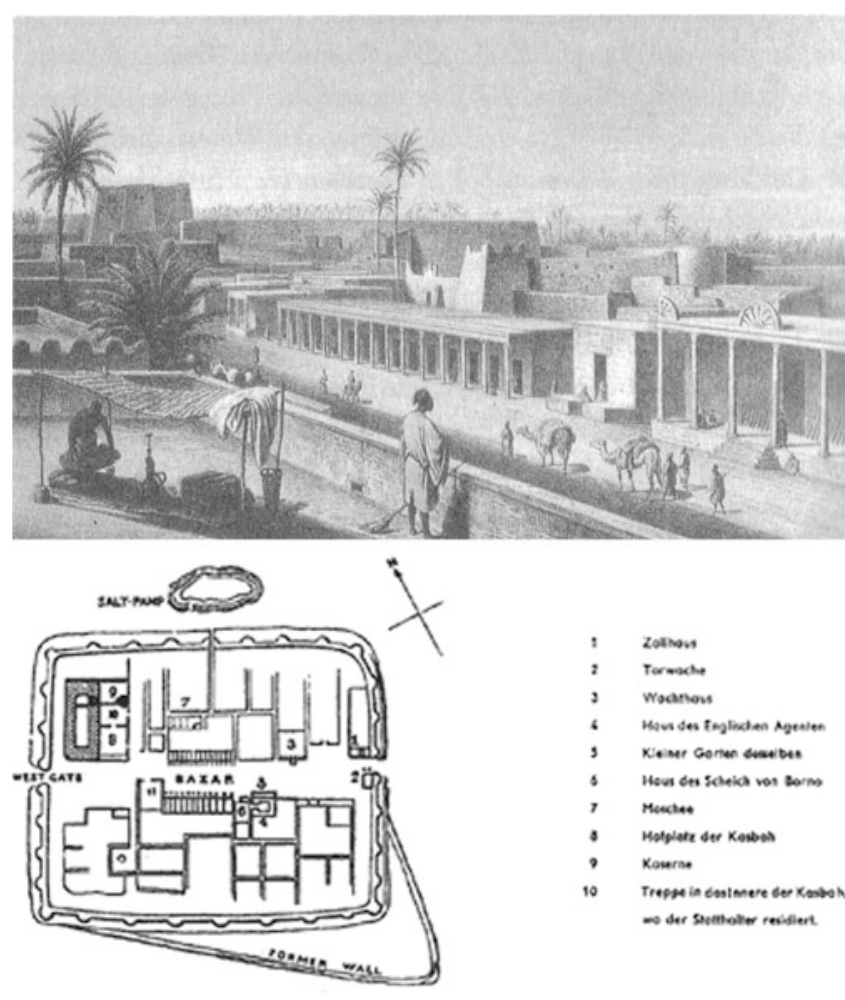

Fig. 6.56 View from the roof of the English consulate of the "Dendal", the main street of Murzuq, which crosses the town from east to west and ends at the square in front of the fortress (Barth 1857)

the wide main street, the "Dendal" (Figs. 6.58 and 6.59), with its small shops, mosques and town gates (Bab al Kebir (6), Bab al Garbi (7), Bab al Bachri (8), the custom house (3), the British Consulate (4) and a cemetery. ${ }^{111}$ In the construction of the town, the travellers recognised traces that hinted at the influence of black inhabitants from the Bornu Empire. ${ }^{12}$ The course of the roads with the "Dendal" as central axis divided Murzuq into quarters, placing it in clear contrast to the course of twisting Arab streets. Barth and von Beurmann mentioned that this type of construction differed strongly from the usual Islamic-Arabic styled town construction of a twisting suq.

Mentioned in the travellers' accounts, there is also a market, a great square in the middle of the settlement. The market was the living and breathing meeting place in the town. According to the Austrian traveller Chavanne, the varied activities of the traders with their goods from all corners of the earth could be observed here. His visit to the market in Murzuq led him to the conclusion that the population of the oasis differed greatly from that of Tripoli and was much more similar to that of the African interior. There was even a coffee house where the (rare) travellers from
Europe mixed with the soldiers of the Ottoman garrison. During the day, however, the hot and dry air often drove people into their cool huts, where according to Barth they indulged in sensual pleasures like palm wine. ${ }^{113}$

All historical settlements in the Fezzan were built from materials that were available locally: in Murzuq, these were salty clay bricks. The layout features the typical, Eastern construction style of dry regions. Narrow alleys meander past twisting complexes of houses. The layout of the historical town construction is best described as "block principle". The living areas of a family are grouped around an internal courtyard. A flat roof can serve as a terrace. Besides the fortress complex, the town once consisted of three parts: "En-Nazla", which was situated to the north of the Dendal, contained lodging houses, inns and warehouses with an open area where caravans could rest overnight. South of the Dendal, the area was named "Ez-Zoueiya", so-called from the Sanussi Zawiya in the vicinity. Finally, in the south of Murzuq one could find the area "Er-Ras" (Fig. 6.60). The expansion of the town and also its number of inhabitants had presumably long exceeded its peak. Of the three former parts of the town, "Er-Ras", which once had been the principal commercial section and home of the shops and houses of the wealthy merchants, was already abandoned in 1857 . Eldblom gathered together the available data on the number of inhabitants in Murzuq in the nineteenth century in the following way: in $1845 / 46$, Richardson estimated the number of inhabitants to be 2000, in 1850-54 Barth and Vogel said 2800, in 1874 Rohlfs said 3000 but for the town and the surrounding area together he named a total figure of 8000 , while in 1879 Nachtigal spoke of 3500 inhabitants in the town and a further 3000 in the proximity. ${ }^{114}$

Many travellers described the climate of the town as particularly uncomfortable because it was very dry and hot due to the lack of air movement. The salt pools of stagnant water on the northern edge of the town further added to the negative impression. This may well have made Nachtigal characterise the town as not particularly "beautiful". Furthermore, it was very unusual in the desert a malaria area. In 1869, Gustav Nachtigal wrote: "The oasis of Murzuq lacks the characteristic of beauty, which most of her sisters enjoy; the town is built on a Sabha area (dried up salt lake) and so endows the inhabitants with malaria, otherwise seldom seen in this region. The houses are built from salty clumps of earth and they disintegrate with great delight from time to time, when no more than a tropical rain shower beats down, which luckily seldom happens."115

In the mid-nineteenth century, Murzuq represented the furthest south-west reaches of the Ottoman Empire. The Ottomans deployed military units to the garrison there. 


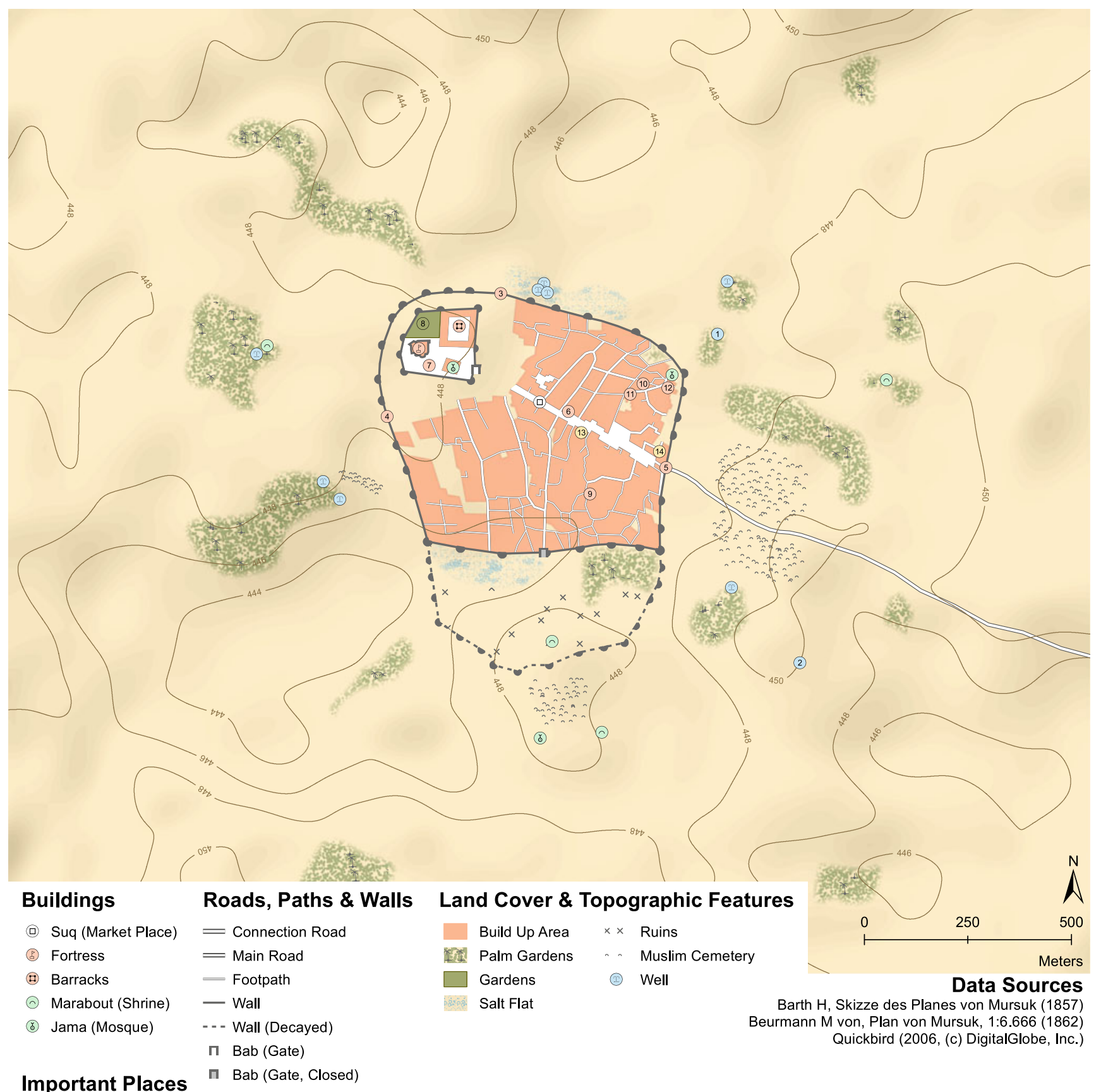
(1) Bir Hadsch Bu Set (5) Bab al Kebir
(9) Hush Ben Alua (13) English Consulate
(2) Bir Barrani
(6) Guard House
(10) Hush Faki Omar
(14) Custom Office
(3) Bab al Bachri
(7) Garrison Bakery
(11) Hush Hadsch al Amri
(4) Bab al Garbi
(8) Garrison Gardens (12) Hush Makursi

Fig. 6.57 Map of Murzuq in 1862

Outside the town, the influence of the Ottomans fell sharply. Various Tuareg tribes lived in their groups in the surrounding desert and mountain landscape. There was very little contact with Africa south of the Sahara. The way through the desert was too arduous. Only the caravan traders used these routes. Yet the difficulties were worthwhile, particularly when it concerned such valuable goods like gold and slaves.

Although the Italians had occupied Murzuq for the first time in 1914, the town was only definitively conquered in 1930. Under Italian rule, Murzuq finally lost its rank to Sabha as the political and economic centre in the 


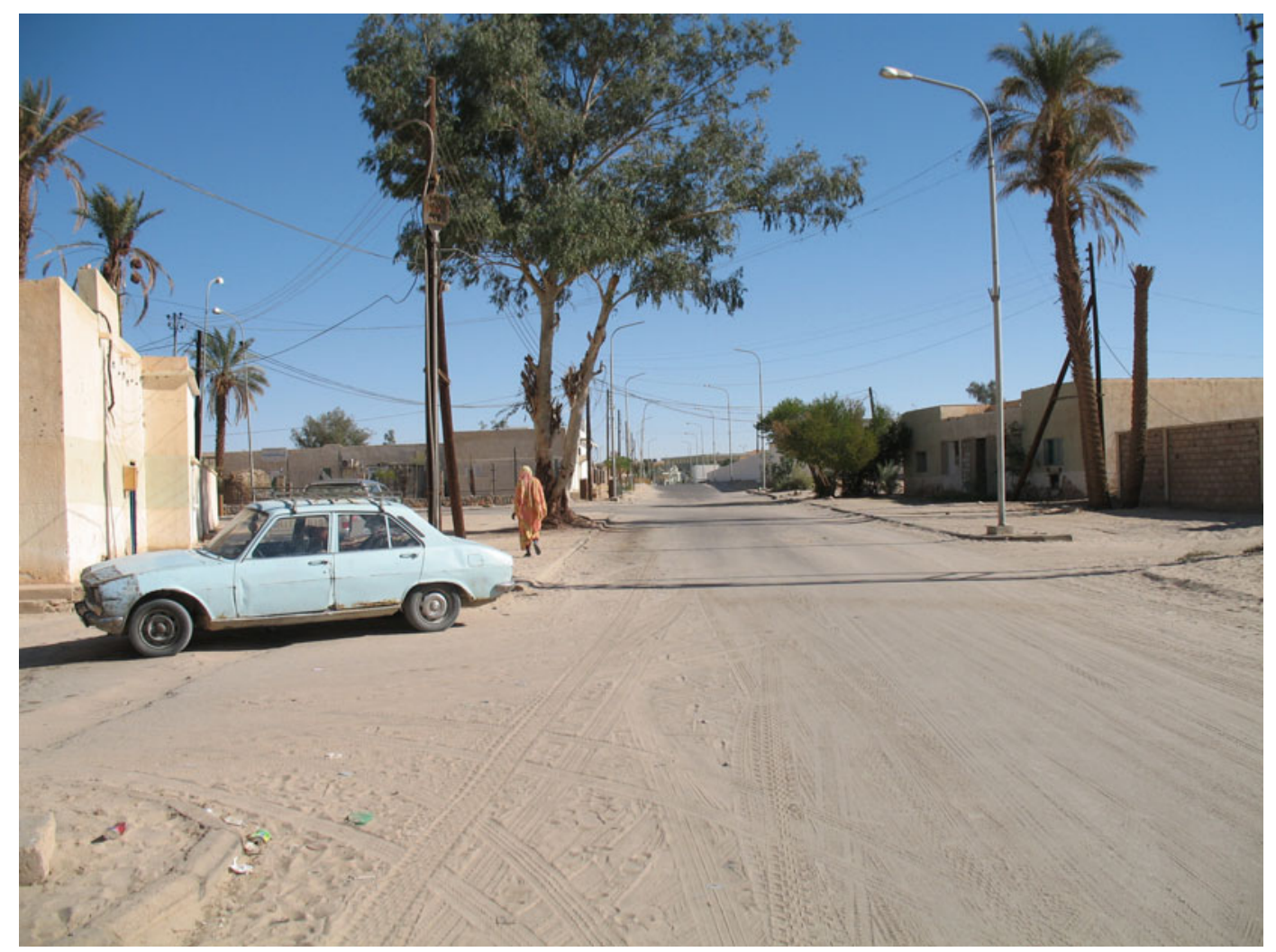

Fig. 6.58 'Dendal' in a photograph of today

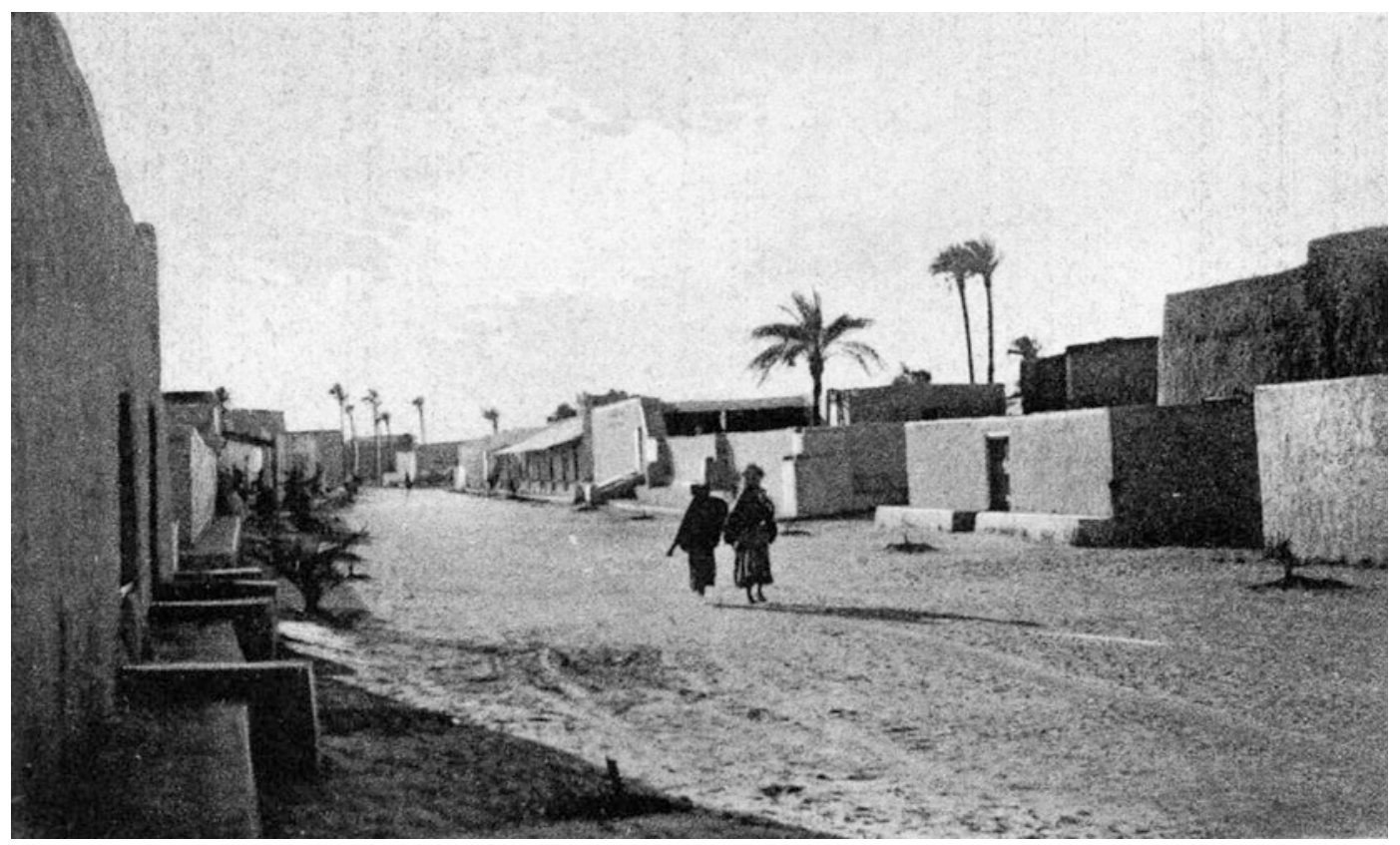

Fig. 6.59 'Dendal' photographed during the Italian colonial period 


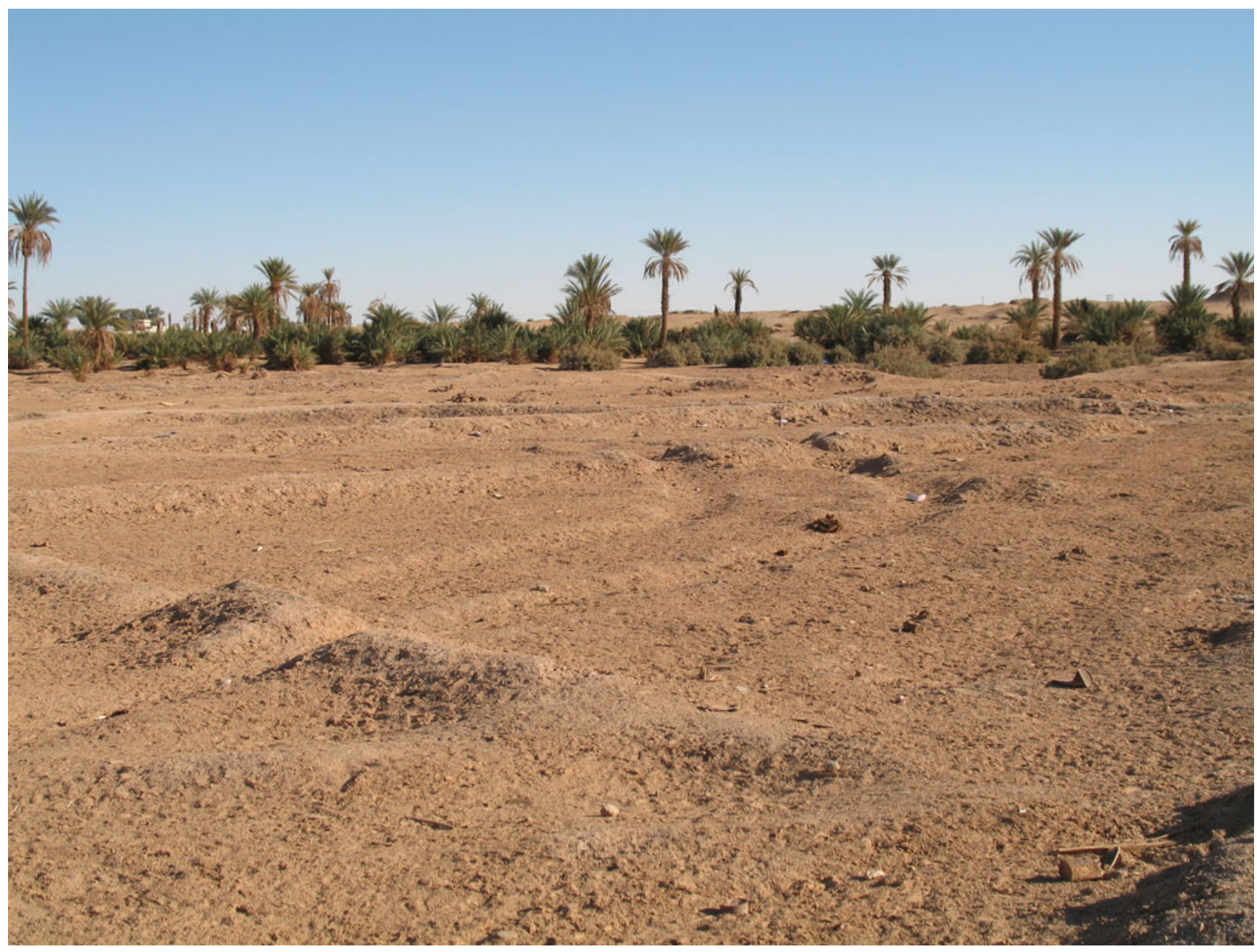

Fig. 6.60 Traces of the former quarter Er-Ras, which was already abandoned when Beuermann came to Murzuq in 1862

Fezzan. ${ }^{116}$ Today, there is a population of 43,732 inhabitants. In contrast to Ghadamis, Murzuq was not able, however, to profit from developments in the tourism business. Until 2010, only few tourists came to the town; it functioned merely as a transport station for desert travellers. The cause of this may have been the urban development of the place during the 1970s. In the course of national modernisation efforts, the historical townscape largely disappeared. The fortress complex with the kasbah from Ottoman times is still just about in existence, but measures for sustainable retention of the property must be urgently carried out. The southern part of the Medina with its traditional clay houses is still in existence. The state of the buildings is, however, extremely dilapidated. Currently, this part of the town is still inhabited, a circumstance which has up to now saved it from total collapse. For the most part, Murzuq has been robbed of every property that possesses any appeal to enable it to function as a tourist magnet. ${ }^{117}$ Today, it is clear that even less remains of what the nineteenth-century travellers, for example, once described and glorified as to some extent romantic.

\subsection{Sharba-Covered by the Sand of the Sahara}

\section{Said Hamid}

The city of Sharba is situated deep in the Libyan Desert, 30 $\mathrm{km}$ to the south-west of the city of Tasawah. It can be reached from the city of Murzuq via Tasawah, a distance of $55 \mathrm{~km}$, and from there to Sharba, which is located at latitude $25.50^{\circ}$ north and longitude $13.30^{\circ}$ east.

The remains of the ancient city of Sharba are scattered across an area of eight square kilometres within the Sharba valley, which is one of the valleys branching out from the Barjuj valley. Archaeological remains indicate that Sharba was a flourishing city, as a result of its strategic important location on the trade caravan route linking Jarmah with Niger and central Africa. In fact, this route left Jarmah towards the south, passing through Maknusa, Tasawah, Qsar Mara, and from there to Sharba, and then across the valleys leading to Kuwar and Zinder, until it finally reached the banks of the River Niger. ${ }^{118}$ 


\subsubsection{Riddle in the Sand}

The remains of this spot pose a big question. For no traveller or any Muslim historian has ever mentioned Sharba. al Idrisi, the author of The book of pleasant journeys into faraway lands (Nuzhat al-Mushtaq), which was written during the twelfth century, did refer to the land of Fezzan and mentioned Jarmah and Tasawah, praising them for their greatness. He stated: "In the Sudan they call Tasawah 'Minor Jarmah', and between Jarmah and Tasawah there is a distance of one stage" ${ }^{119}$ Sharba was not mentioned in the early Arab sources, and it was not visited by the European explorers of the eighteenth and nineteenth centuries, nor did they mention it. Perhaps Sharba was one of the cities referred to by the Arab historian Ibn Abd al Hakam, who wrote about the conquest of the land of the Garamantes by Uqba ibn Nafi. He wrote about a big city on a hill in the desert, and whose inhabitants resisted Uqba, compelling him to take the city by force.

It is known that the Arab leader Uqba ibn Nafi led a campaign in 669, starting from the city of Mghamdas, in the vicinity of Sirte, and moved deep inside the Libyan Desert, conquering, one by one, its cities, oases and fortresses.
Subsequently, he returned to Zawilah, perhaps via the al Qatrun route. From Zawilah, he returned to his headquarters in Mghamdas, after the absence of five months, which he spent in a jihad, aimed at spreading Islam. Thanks to this campaign, the Arab Muslims came to know the passage to the Ajal valley. Moreover, they could experience the shortest route that linked the Mediterranean Sea to the Sudan, which passed through al Qatrun and Tajarhi. ${ }^{120}$

\subsubsection{Prosperous Town Deep in the Sahara}

The archaeological remains of the city of Sharba indicate that it was a prosperous city, given its location on the caravan route. Rainfall, as well as underground waters which were close to the ground, secured the city's water supplies. It was located in one of the valleys. A huge wall with numerous towers used to encircle Sharba. There are also remains of two big buildings which might have been two fortresses. Sand covered most of the city's buildings, and nothing remained of them except high structures. In the vicinity of the city, on a low hill, there is a big burial ground that comprises a number of big circular tombs. These may be

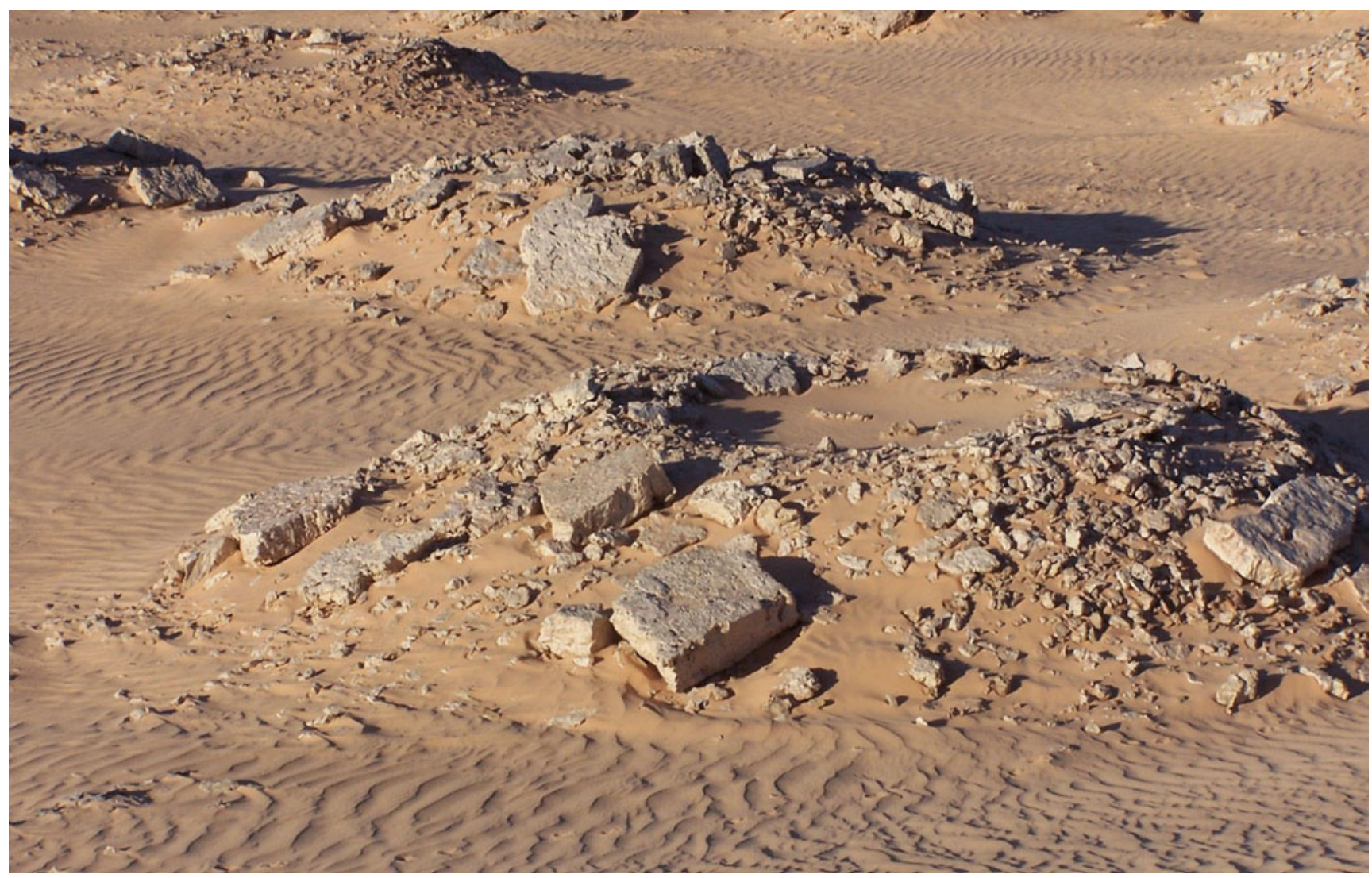

Fig. 6.61 Pre-islamic graves: In the vicinity of the city, on a low hill, there is a big burial ground comprising a number of big circular tombs. These may be the tombs of the inhabitants of the ancient city of Sharba, and they resemble the tombs of the Garamantes period 
the tombs of the inhabitants of the ancient city of Sharba, and they resemble the tombs of the Garamantian period. ${ }^{121}$ British archaeologists tentatively identified the site as an Garamantian town. ${ }^{122}$

The prosperity of the city of Sharba continued even after the appearance of the camel in the Sahara desert. The camel was brought from Western Asia after the Pleistocene period. Rock engravings show that the camel soon appeared. According to Mori's chronology, the camel rock drawings were made during the period between BC 1500 and the end of the first century AD. The first reference to the camel in North Africa goes back to $46 \mathrm{BC}$. The utilisation of the camel in caravan trading and in agriculture soon increased. Rock inscriptions were also found in the city of Qarza and in other areas.

Following a change in the climatic conditions in the Libyan southern region, the temperature rose and the quantity of rainfall and humidity gradually decreased. As a result, horses could not penetrate the desert, whereas the camel ventured on new tracks crossing the desert. New desert commercial cities emerged during the sixteenth century, among them Murzuq in 1550. Soon after, it became the seat of the Awlad Muhammad tribe. As regards Sharba, one may say that it continued to be active for some time after that. In fact, it was connected with Murzuq via a number of fortresses known as the Umm al-Hammam fortresses, of which the Tqalqalat, al-Manashi and Tamira fortresses were the most important. ${ }^{123}$ What is clear until now is that the series of three dates from different contexts confirms that occupation continued into the post-Garamantian period. The latest of the three dates belongs to the eleventh to early thirteenth century AD. ${ }^{124}$

After that, Sharba started to lose its importance and its inhabitants abandoned it. Nothing is left of it except its remains which point to its prosperity for a number of centuries. Sharba has fallen into a state of slumber.

A number of factors led to Sharba losing its commercial importance. Among them are the depletion of its water resources, and their penetration deep inside the ground, which made it impossible for the inhabitants to reach them. Another reason was the inexorable advance of sand, and the deviation from it of the trade caravans, which opted for new cities like Murzuq. These factors prompted Sharba's inhabitants to abandon their city. Sharba was covered by sand and became yet another old city which fell into oblivion (Fig. 6.61). ${ }^{125}$

\subsection{Jarmah-Capital of the Garamantes}

Said Hamid

The city of Jarmah is situated in the so-called Valley of Life, previously known as Ajal valley, about $160 \mathrm{~km}$ south-west of the city of Sabha. Jarmah is about $30 \mathrm{~km}$ east of Awbari. It is located at the intersection of latitude $26.40^{\circ}$ north with longitude $13.00^{\circ}$ east.

\subsubsection{The City of the Garamantes}

The Greek historian Herodotus, who lived in the fifth century BC, was the first to write about Jarmah. In the fourth book of his Histories, he wrote that after a journey of ten days from Awjilah, one reached another hill of salt, water and many date palms, as in other places, and this place was inhabited by the Garamantes. He added that they were in great number and that they planted the soil after having spread salt over it. These Garamantes, mounted on their chariots driven by four horses, and chased after the Ethiopian cave dwellers. Historically the Garamantes initially built their dwellings on the high summit of Zenkekra Mountain. Later, during the third century AD, they came down and settled at the foot of the same mountain. They left many inscriptions on rock, as well as drawings on Zenkekra Mountain, depicting cows, giraffes, horses and ostriches.

Historical sources refer to Roman raids against Jarmah led by Cornelius Balbus in the year 19 BC. During the first century AD, the city of Oea (Tripoli) sought the help of the Garamantes in its dispute with the city of Leptis regarding the ownership of some lands. This led to the Garamantes' siege of Leptis which lasted for many days, until the Romans intervened and put an end to it. Later, in the year $69 \mathrm{AD}$, the Roman leader Valerius Festus sought vengeance against the Garamantes and raided their territories. By doing so, he demonstrated the Romans' ability to penetrate the desert shield of the Garamantes. A third Roman campaign was led by Suilius Flaccus in 87 AD. Apparently, this campaign was launched for economic reasons, namely to reach the desert's commercial centres. The Romans succeeded in paralysing the Garamantes' movement towards these commercial centres, which were situated north of Jarmah, thus limiting this city's influence over the surrounding regions (Fig. 6.62).

During the second and third centuries $\mathrm{AD}$, the region enjoyed a period of peace and stability. This enabled the Garamantes to build a new city in the innermost sector of the valley. They built many buildings with stone and mud, and their structures included columns with Ionian, Doric and Corinthian pillars. The new city of Jarmah was enclosed within defensive walls which could be penetrated by three gates.

\subsubsection{Wind of Change}

The Arab Muslims, under the leadership of Uqba ibn Nafi, took control of Jarmah in 663. The people of Jarmah were invited to accept Islam, and they did not fail to accept the 

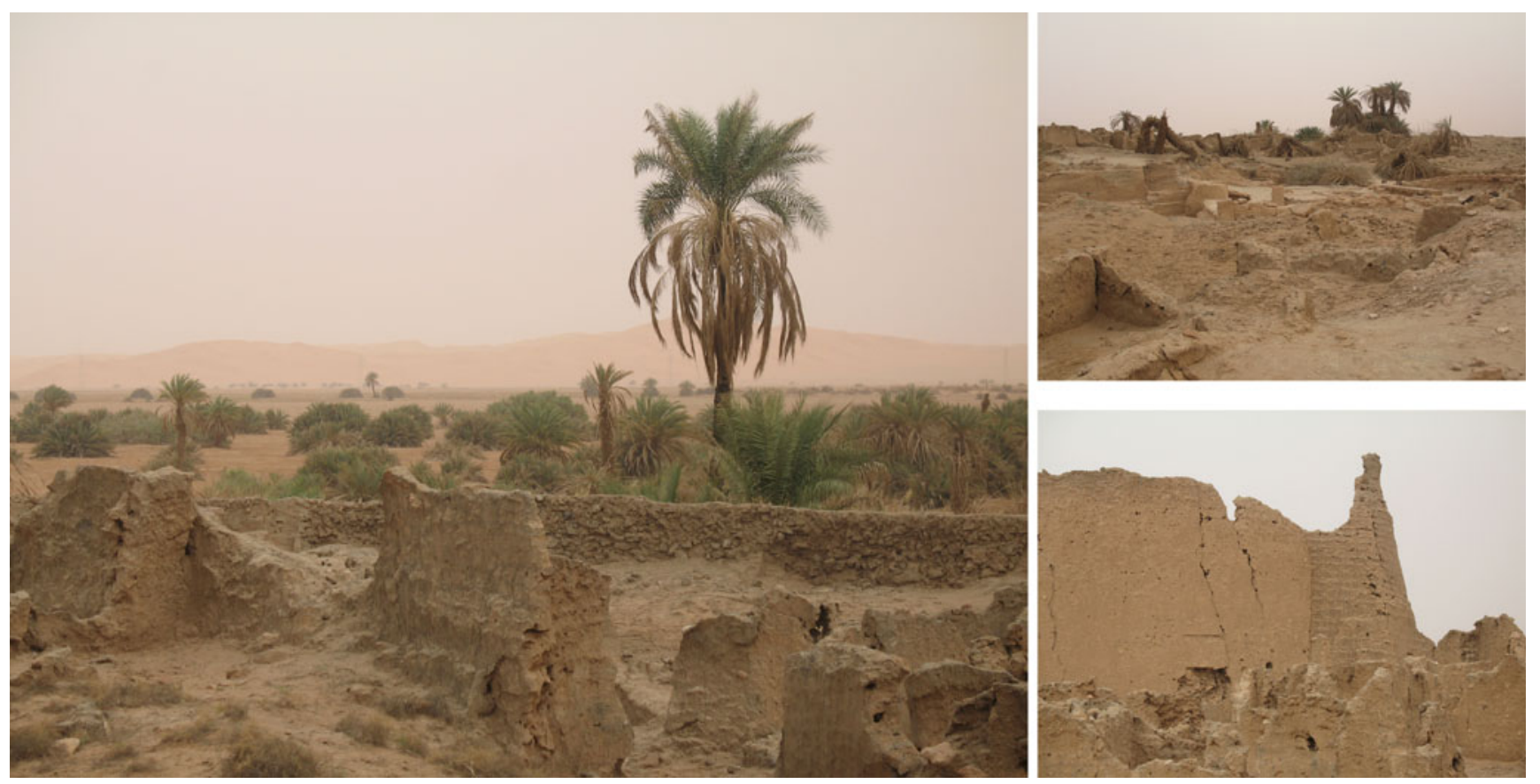

Fig. 6.62 Old Garama has been a domicile for the Garamantes, an ancient nation dwelling in the Fezzan. From the fifth century BC to the fifth century AD, the Fezzan was home to the Garamantian Empire, a city state which operated the trans-Saharan trade routes between north and south
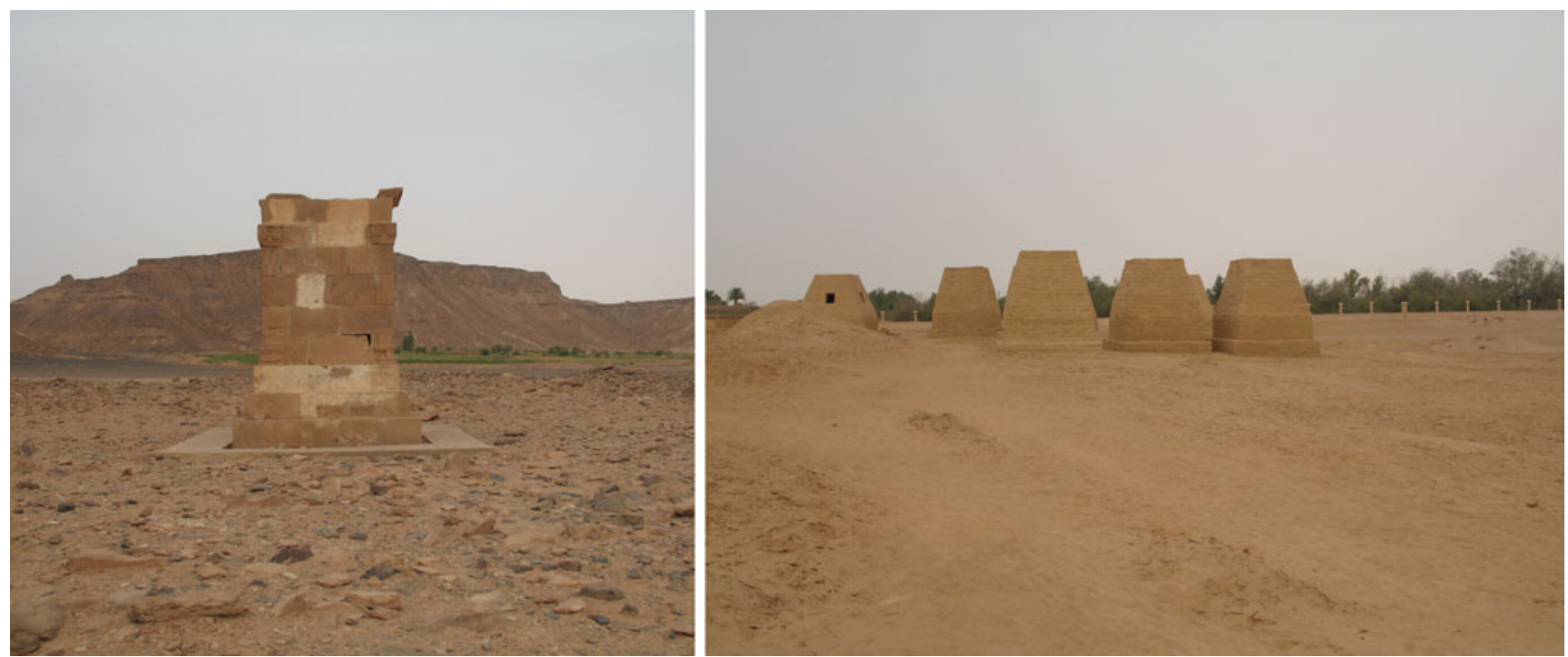

Fig. 6.63 Garamantes' traces are still there among the ruins of the old city. The different types of cemeteries are scattered around the region. On the left, a Roman grave, and on the right the kings' graves of the Garamantes near Jarmah

invitation. The Arabs then directed themselves towards the desert castles (qsur) of the Fezzan and took control of them as well.

The Arab historians and geographers made very few references to Jarmah; however, it seems that during the eleventh and twelfth centuries, the city still retained its importance. According to the great traveller al Idrisi, Jarmah was located at a distance of less than one day from Tasawah, situated in the Ataba valley. These two cities were of the same size and had the same number of inhabitants. They cultivated date palms, white corn and barley, and they used to irrigate their fields and gardens with particular equipment which drew water from wells. 
Peaceful times, particularly during the seventeenth and eighteenth centuries, led to the flourishing of the caravan trade in Jarmah. However, at the end of the nineteenth century, the oasis witnessed the decline of this desert commercial activity due to the fact that in Europe the demand for desert products, such as ostrich feathers and ivory decreased dramatically. Moreover, this period coincided with the opening of new, alternative and cheaper sea and land routes. In view of the drastic fall in their income, the caravan traders had no other choice but to give up their business. The caravan trade came to an end at the beginning of the twentieth century. ${ }^{126}$

\subsubsection{Connecting Routes}

Jarmah was connected to numerous caravan routes, either those coming from the north, from the south or from the west. The following are among the most important ones:

Linking Jarmah to the Mediterranean coast:

- The Ghadamis, Adiri, Awbari and Jarmah route.

- The Tripoli, Gharyan, Hamadah al Hamra, Adhan lakes, Awbari, the Valley of Life and Jarmah route.

- The Sirte, Jufrah oases (Zillah, Waddan, Hun, Soknah), Sabha and Jarmah route.

Linking Jarmah to the south:

- The Jarmah, Murzuq, Taraghin, Zawilah, Tazerbu, al Kufrah, al Awaynat mountains and Marwa route (in the Sudan).

- The Jarmah, Tasawah, Qsar Mara, Sharaba, Murzuq, al Qatrun, Fayalarju, and Kanem route.

- The Jarmah, Tasawah, Qsar Mara, Sharaba, Idhan valleys, Murzuq and Kuwar (in Niger) route.

- The Jarmah, Mathendous valley, Amsak Staft heights and Kuwar (in Niger) route.

- The Jarmah, al Awaynat Sardalas (near Acacus Mountains), Ghat, Wargla, Tamanrasset as far as the banks of the river Niger (Fig. 6.63).

\subsection{Ghat-a Picturesque qser on the Frontier Between the Fezzan and the Algerian Sahara}

Mansour El Nayedh

Ghat is situated in the south-west of Libya at a distance of about $1360 \mathrm{~km}$ from Tripoli, $582 \mathrm{~km}$ from Ghadamis and about $15 \mathrm{~km}$ from the Algerian border. It is located at the intersection of longitude $57.7^{\circ}$ east with latitude $24.37^{\circ}$ north.
Ghat was a qsar of the Sahara among the Tuareg Adjer and a major terminal point on the trans-Saharan trade routes linking the Mediterranean ports with the main commercial centres in Kano, Zinder and Agades. Moreover, Ghat is situated in an area which is ideal for human settlement, given the availability of underground water which is quite close to the surface. Its valleys are vibrant with vegetation and small trees of the acacia type, the Alhagi maurorum, the Ampelodesma tenax and the Branbah plant, in addition to the herb bushes which cover extensive areas of the valleys. Its desert climate is characterised by great heat in summer, cold weather and lack of rain in winter.

\subsubsection{Important Cultural and Religious Centre}

The city's origin is still shrouded in obscurity. It may go back to ancient times, because near the valley of Tanezzouft, whose valley lies in a north-south direction between the bank of primary sandstone on the side of the Tadrart in the east and the similar plateaus of the Tassilin'Adjer in the west, the land is fertile and the waters are abundant. It has been a transit area for commercial caravans plying the desert. Furthermore, numerous rock engravings and some necropolises found, for example, in al Barkat or Tin Alkoun, and indicate that the region was inhabited in ancient times. The origin of modern Ghat probably goes back to the fourteenth century. The name Ghat was first confirmed by the great Arab traveller Ibn Battuta who travelled the area as far back as the second half of the fourteenth century. ${ }^{127}$

Islam and the Arabic language probably reached Ghat during the fourteenth century, and it developed into an important religious and cultural centre of the region. For travellers of the desert, the oasis must have appeared as a big fortified city. Indeed, Ghat's Medina is fortified in an irregular rectangle of 700 by $500 \mathrm{~m}$ in area and surrounded by a wall made of stones and clay. Part of it is also the two suburbs, quite close to it, namely Tunein and Tedremit (Fig. 6.64). It has four gates leading to the city:

- The northern gate, known as Bab al Cher (5).

- The eastern gate, known as the Bab al Kalala (6).

- The southern gate, known as Bab Tafachachat (7). There once had been the Bab Eschef en Kena in the south (3).

- The western gate, known as Bab Tamalchat (4).

Ghat (Figs. 6.65, 6.66, 6.67 and 6.68) has been famous for its markets and these were the destination of many merchants. Dozens of them from different places lined the aswaq. The nineteenth-century traveller Muhammad al Otsman al Hachaichi remarks that most of the traders of Ghat were people from Ghadamis and Tripoli. Those groups 


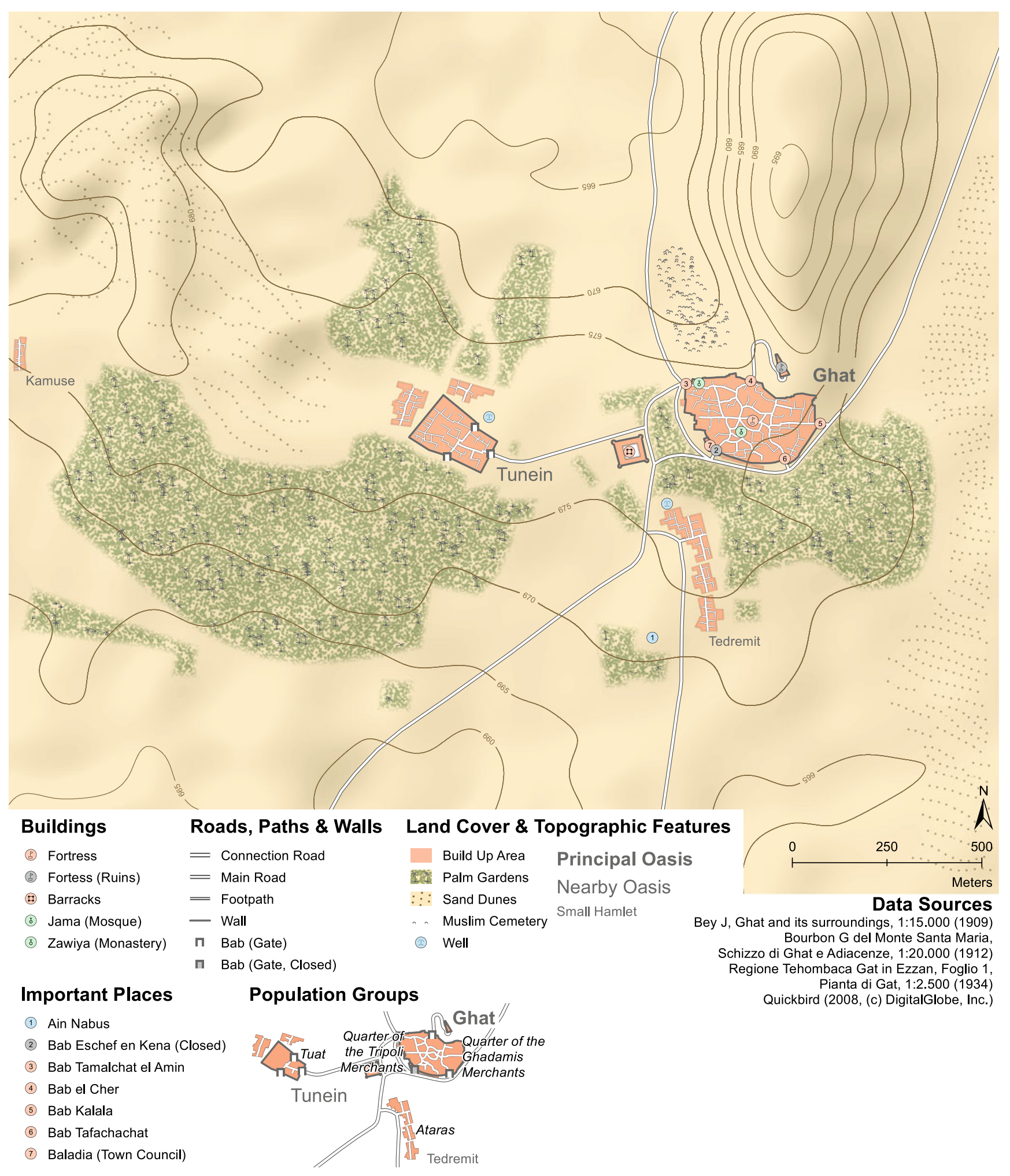

Fig. 6.64 Map of Ghat at the beginning of the twentieth century 


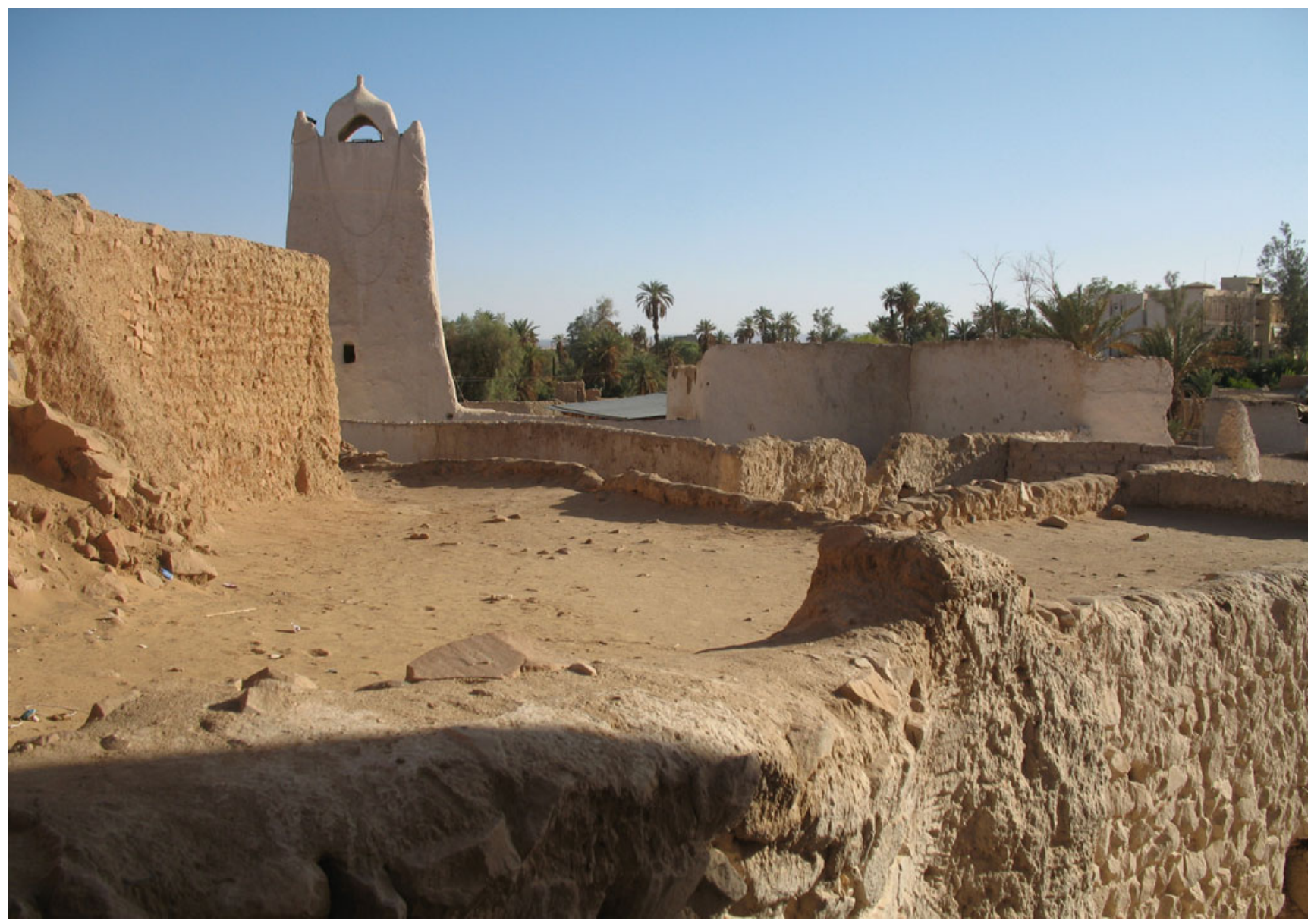

Fig. 6.65 Old town of Ghat is built at the foot of Cocaman Mountain, which situated to the north, holding the fortress, which was initiated by the Ottomans and reconstructed later by the Italians

tended to concentrate on their own neighbourhoods. The Tripoli merchants were situated in the west of the Medina, while the Ghadamis traders had their quarter in the east of town (Fig. 6.64: Population groups). The Tuareg hired their camels to them. At the Tafachachat gate, which overlooked a spacious square, merchants from Ghat met their counterparts from many other regions.

There were also local markets which used to be set up in the city as well as outside. Two important markets used to convene twice yearly, one in summer and another in winter. They usually lasted at least for a period of about three months. It was the time when the large trans-Saharan caravans came to Ghat. There were also markets dedicated to women's needs, selling perfume, incense, herbs, clothing, etc. The traveller Richard Dasson described the arrival of trade caravans from Kano, Bornu and Twat in the year 1845, carrying all kinds of goods for the city's markets. One should mention that the caravan merchants did not arrive in Ghat exclusively from the desert regions, the Fezzan, Ghadamis and Tripoli, but also from Tunisia and Algeria. These traders would come to Ghat to trade and exchange merchandise, particularly during the month of October. The most important merchandise transported by the caravans to Ghat included slaves from the various Sudanic areas, ivory from Bornu, ostrich feathers, tanned leather, leopard hides and musk from Mali, rhinoceros horns from Wadai, Bajarmi textiles, Sudanese traditional crafts as well as products manufactured by the inhabitants of Ghat. The oasis acquired considerable revenues from passage dues paid by transiting caravans. The city and its traders benefitted from the exchange of products and from the city's vigorous markets.

In addition to trading activities, agriculture was considered one of the main economic resources of the oasis. The inhabitants cultivated grain, barley, white corn and various types of good quality dates which were at the centre of their diet. Moreover, vegetables and fruits such as pepper, onions, tomatoes, watermelons, peaches, figs and lemons were also grown in the valleys. Here, there was plenty of underground water, rather near to the surface. For the irrigation of the agricultural products, water was drawn from wells and springs. The inhabitants of Ghat were also engaged in animal husbandry, including the breeding of camels, particularly of 

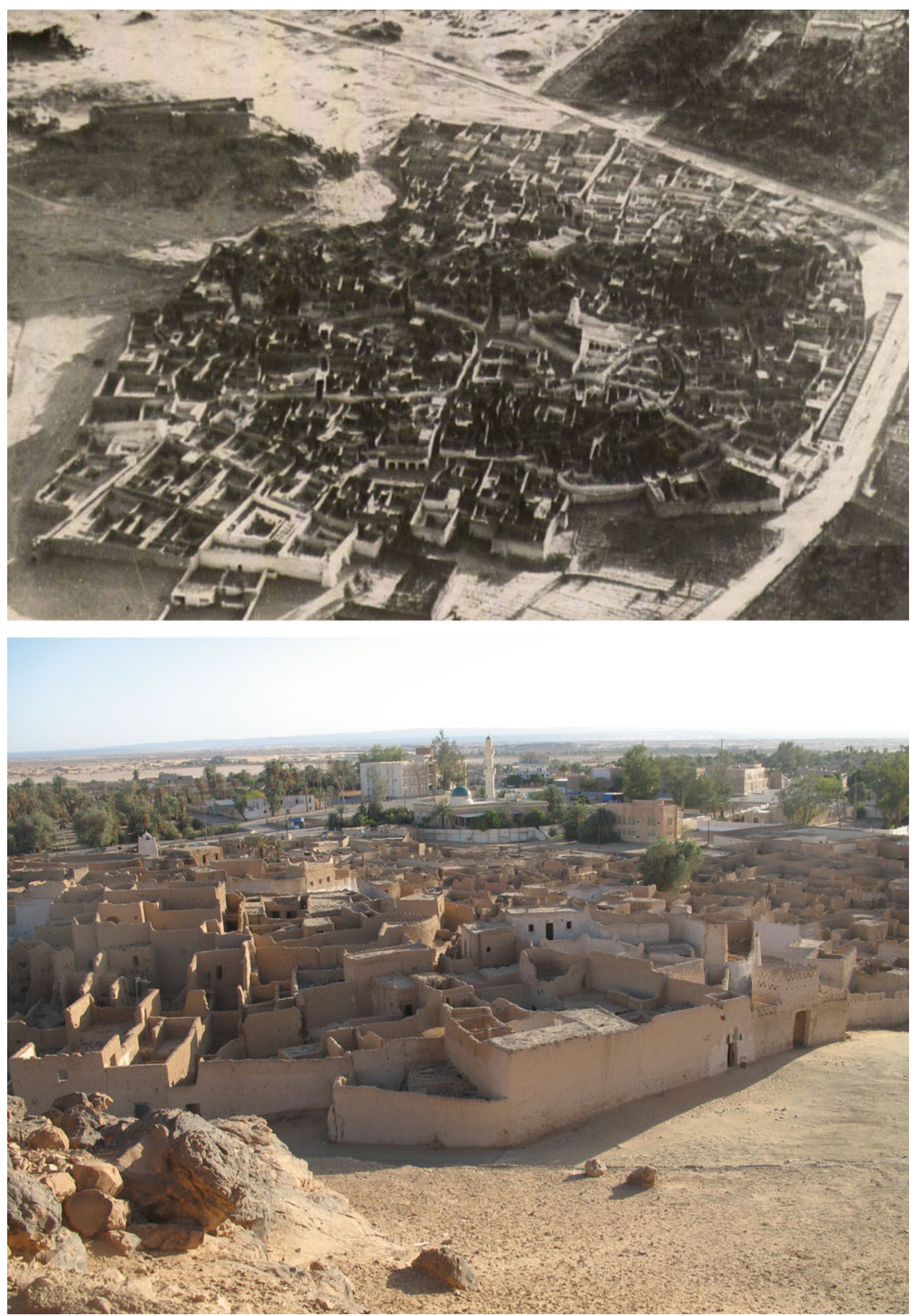

Fig. 6.66 Ghat was a major terminal point on the trans-Saharan trade route. It was a stronghold for the Kel-Adjer Tuareg federation, whose territory covered most of south-western Libya, until 1913, when the city was occupied by Italy as a colony. Many goods were traded in the old town. The most important merchandise transported by the caravans to Ghat included slaves from the various Sudanic areas, ivory from Bornu, ostrich feathers, tanned leather, leopard hides and musk from Mali, rhinoceros horns from Waddai, Bajarmi textiles, Sudanese traditional crafts as well as products manufactured by the inhabitants of Ghat 


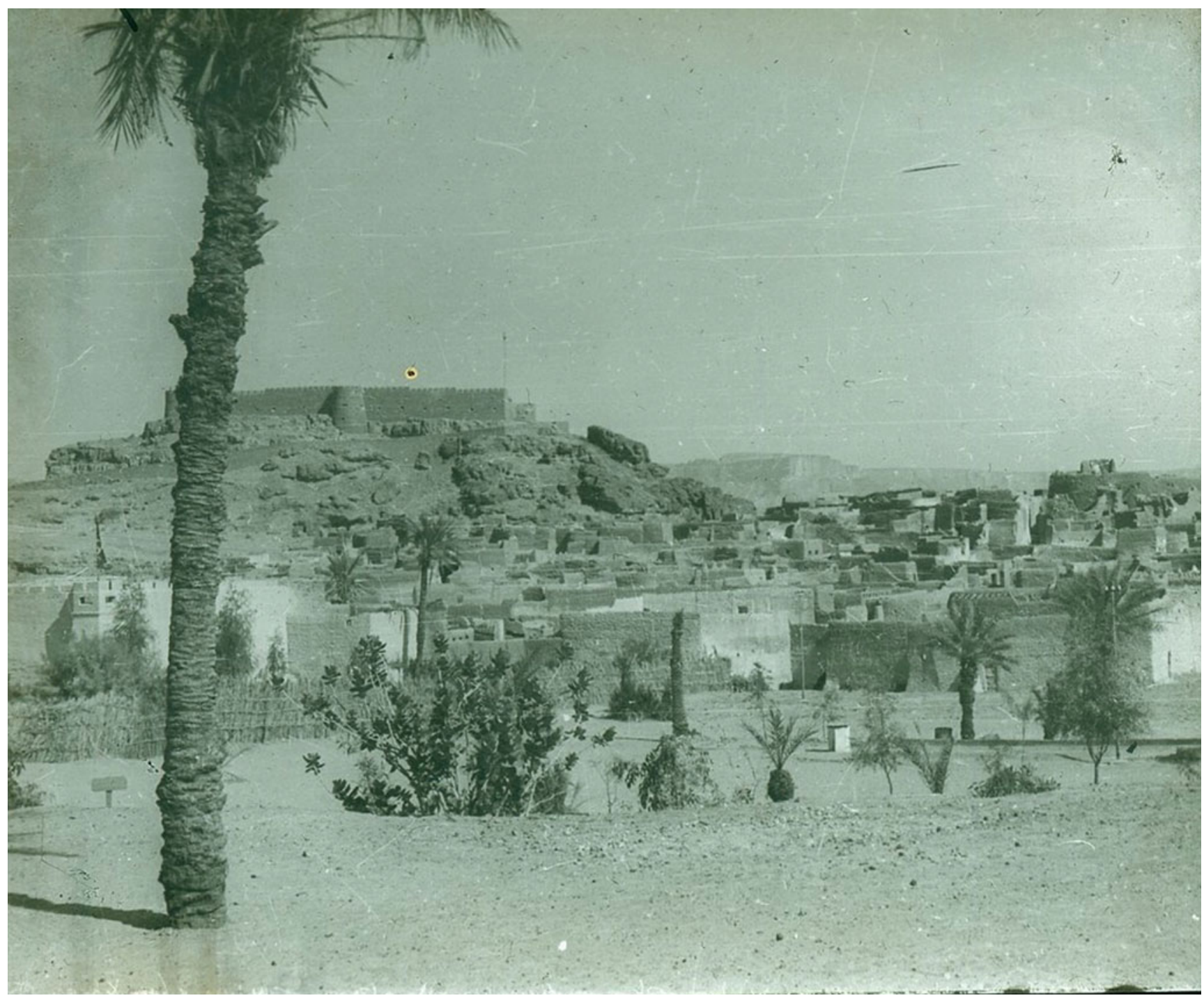

Fig. 6.67 Ghat photographed during the Italian colonial period

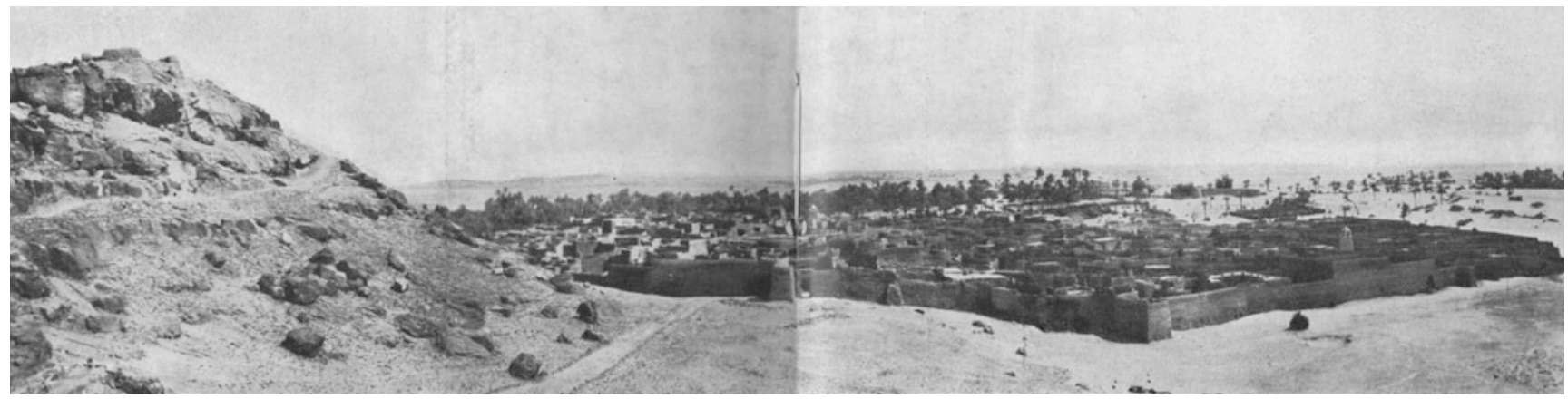

Fig. 6.68 Ghat photographed during the Italian colonial period (Castigliola 1930, 84-85)

the Mahdiya type, as well as goats and sheeps. Moreover, people from Ghat were engaged in such trades like tanning, the manufacture of traditional weapons, drums, leather shoes, products from palm leaves, woollen and fur textiles and tents. They also trained camels of the Mahri type, used in camel races, especially on social occasions.

For a long time, Ghat remained independent, governed by a hereditary amghar and was under the somewhat heavy 
protection of the Tuaregs. In 1875, the Ottomans installed a garrison there, which is situated on top of a hill besides the old town, and remained until 1914. As a major terminal point of trans-Saharan trade, Ghat was located at strategic crossroads linking four routes:

1. The western route towards Timbuktu, passing through Twat and Ain Salih. Merchandise would come from Timbuktu passing through Arwawan in the direction of the north-east through Algerian desert routes and reaching Ain Salih in Algeria about $900 \mathrm{~km}$ west of Ghat. Caravans would stop in Ghat on their way towards the east having traversed desert routes dotted with springs and wells of potable water.

2. The southern route, or the Bornu and Zinder route, passing through Tamanrasset. This was where the roads branching out from Bornu in Niger and Zinder in Mali. Both roads met near the Libyan-Algerian border, passing through the regions of Tamanrasset which offered some pasture and wells of drinking water. The route then reached the region of Ain az-Zan situated on the Libyan southern border. The caravan route moved north in the vicinity of Tadrart Mountain and the Janit area just $40 \mathrm{~km}$ away from Ghat. From Ghat, the route proceeded northwards towards the Mediterranean harbours.

3. The eastern route, or the Bornu-Ghadamis route, passed through the regions of Kuwar, al Qatrun, Tajarhi and Murzuq until it reached Ghat. The route started at Bornu and Agadez, and it proceeded northwards, passing through Atqiqmi and the regions of Kuwar. It followed some southern desert routes until it reached the western parts of Tibesti, known as Tammu. It moved north for about $180 \mathrm{~km}$, towards Tajarhi and al Wigh, renowned for its spring of drinking water. The route then led further north through Mara territory, in the region of Madrusah and al Qatrun, west of the Bin Ghunaymah Mountain, with its rich vegetation. From there, it moved slightly towards the north-west until it reached Ghwat and al Baydan, about $200 \mathrm{~km}$ east of Murzuq. It then led to Murzuq and from there other roads branched out. The western road was the one which led to Ghat. It passed through Umm al-Hammam and Tasawah and then moved south-west through the Idhan areas of Murzuq, turning towards the south-west, in a semicircle, passing through the paths of Milt, close to the Akakus Mountains, towards Tin alKoun and al-Birkat, in the southern neighbourhoods of Ghat, which were rich in drinking water. In the vicinity of the paths of the Milt and Akakus Mountains, some vegetation, such as the ampelodesma tenax, and pasture for camels grew. Finally, the route reached the commercial city of Ghat. The distance between Murzuq and Ghat was about $546 \mathrm{~km}$.

4. The northern route started from Ghat, at the northern gate, known also as Bab al-Khayr, and proceeded northwards through Tanezzouft valley and the al Awaynat region. Here, a number of wells were located, among them the Bilaj well. The route stretched further until it reached the western parts of Awbari which were well known for the abundance of wells and springs, such as Ain Taqhiri and Ain Azwa, and also for their rich vegetation. This route was quite easy for caravans. They reached the rocky desert of Tatghart, leaving behind them the Hasawinah Mountains to their east. Here, the caravans took supplies of water. This region was a sandy area of about $70 \mathrm{~km}$, rich in wells and springs, among them the Tawil well, Adamir well, Yur Sida well and the Azar spring. The caravans then came to a mountain range in the limits of Ghadamis, that reached an altitude of $500 \mathrm{~m}$ above sea level, west of the red rocky desert. Moving northwards, along the Algerian border, the caravans arrived at the city of Ghadamis. From there, roads branched out, according to their importance, towards the north-east until ending in Tripoli. ${ }^{128}$

\subsection{Al Qatrun-a Pearl in the Midst of Sand}

Najmiya as-Sadeq at-Tellisi

Al Qatrun is located at the south-west of Libya in a depression known by the Italian writers as the depression of wisdom. Today, it is known as al Qatrun depression which is at about 510 above the sea level and at coordinates longitude $25^{\circ}$ north and latitude $14.45^{\circ}$ east.

\subsubsection{Most Severe Arid Part of the Fezzan}

The area of al Qatrun includes four small different villages called al Qatrun, Tajarhi, al-Bakhi and Madrusah. This region is the poorest area of the Fezzan region in its natural, agricultural and animal sources. It is located at the most severe arid part of the Fezzan due to its location at the heart of the Sahara which is famous for its aridity and high temperature. Generally, the depression is a number of small, sparsely populated villages within an area of about $60 \mathrm{~km}$ northbound. The area is bordered by the southern edge of Jabal bin Ghunaymah, the highlands of Debassa Mountain, the depression of Alweg al Kabir and the Idhan of Murzuq. The depression itself includes a number of surfaced wells of not high-quality water, which were used by the caravan travellers crossing the area towards Murzuq, Ghat and Tripoli or towards the south to the central African countries 


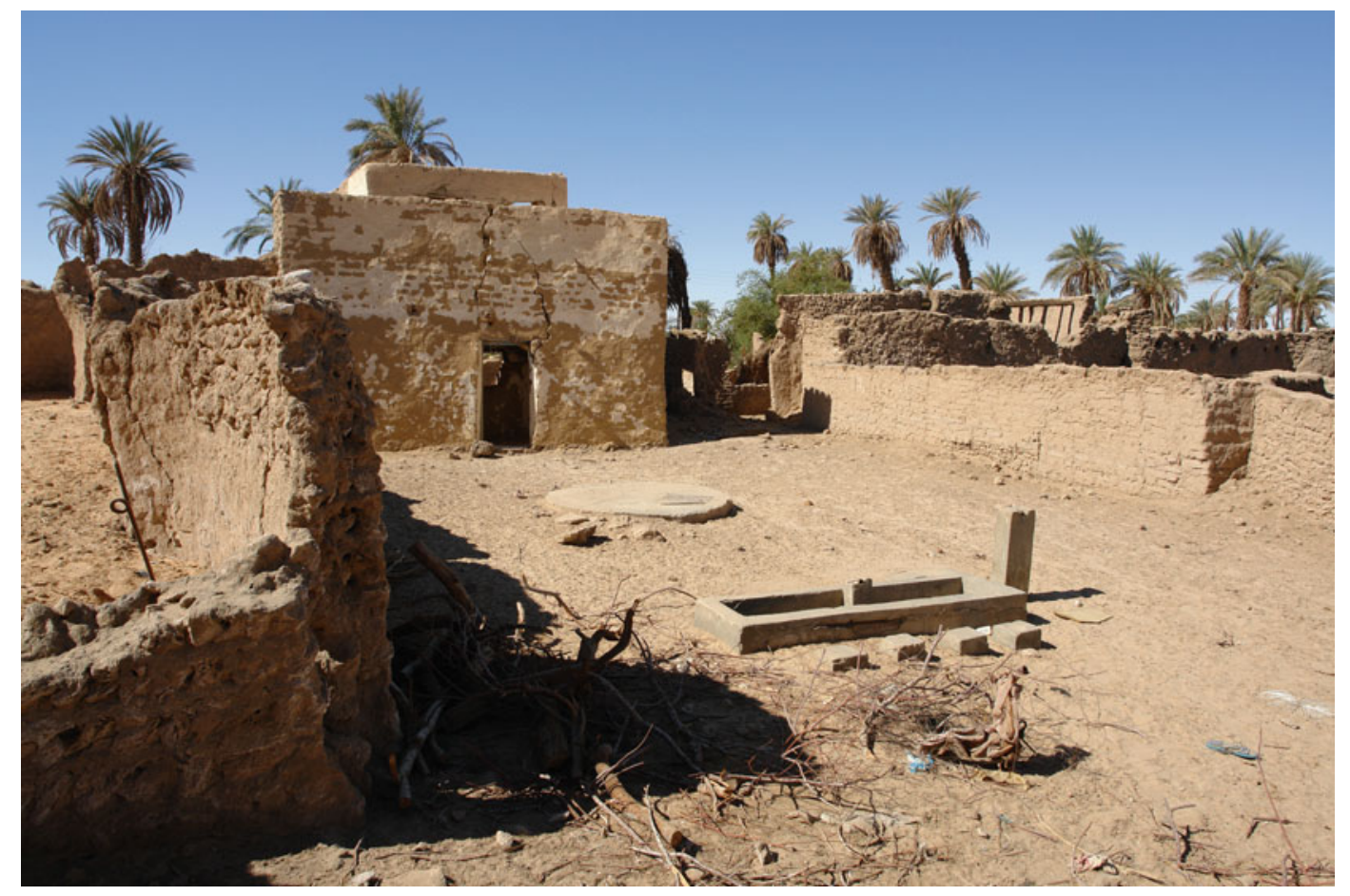

Fig. 6.69 $\mathrm{Al}$ Qatrun is a flat oasis, where palm trees are plenty and surface water is nearby

through areas of Tania al Kabir, Ghiadar, Tania Saghira and Bir al Waar. The wells at the northern part of the depression are located in immediate proximity to each other, but the distance between the water holes increases as the route continues southwards to Tummo Well. Towards Murzuq, the next well is situated at Bir um al-Adam, and another well is located near the castle of Hatiyat Mastuta half way between al Qatrun and Murzuq.

The scenery on the southern route is characterised by hills as well as the picturesque highlands especially between Tajarhi and Tummo Well. These specific geographical features were used as landmarks to guide caravans and Sahara travellers. Regarding the western direction, the surrounding area is mostly characterised by high sand dunes (Idhan of Murzuq) that crouch eastwards to cover a large part of the depression.

\subsubsection{Al Qatrun and Its Neighbouring Villages}

The people of al Qatrun and the surrounding villages are mainly of Tubu tribes. They once came from Bornu and the area of the Tibesti Mountains. The other inhabitants are called the al Qatruns, who descend from the mix of Garamantes and the Arabic tribes which settled in the area. Popular indigenous literature recounts that Oulad Jaber (Sons of Jaber), the Marabouts who form the majority of al Qatrun village, descended from their grandfather Jaber, one of Saguia el-Hamra Marabouts, who came from the Maghreb to the area in the fifteenth century. Jaber is considered the founder of al Qatrun. The local people of this town are divided into four tribes: the Aoulad (Sons of) al-Haj Hamed, Aoulad Abel Rasoul, Aoulad Mohammed and Aoulad Abdullah. The next town is al-Bakhi, which was founded by a Marabout called Yahya, who came from Saguia al Hmara in the same period. In addition to the locals, the Tubu tribes formed the society of this town, and some of them moved into the nearby village of Madrusah. These Tubu tribes settled the region since ancient times and were governed by a strict tribal system (Figs. 6.69 and 6.70).

The economy of the area depended mainly on the field products for local consumption and on the palm trees, which formed the main food source of the area. In 1911, there were about 102 farms including 112 surfaced wells with 31,500 productive palm trees in addition to 17 camels, 124 donkeys and 228 goats. Furthermore, the wells of al Qatrun are relatively salty, while their depth ranges from one metre to three metres. Due to the vicinity of the water table from the surface, several kinds of grass and plants, which bear the weather aridity and the salty soil, grow in the area. In addition, palm tree forests extend for long distances from Hatiyat ad-Dakeer to Qsar Mariana and Bir Shibou near south Tajarhi and from the eastern side at Bir Mastuta, Hatiyat Umm al Edam, Majdul area and the surrounding villages of the sand dunes of Idhan Murzuq. Desert plants such as Acacia and Tamarisk as well as different local 


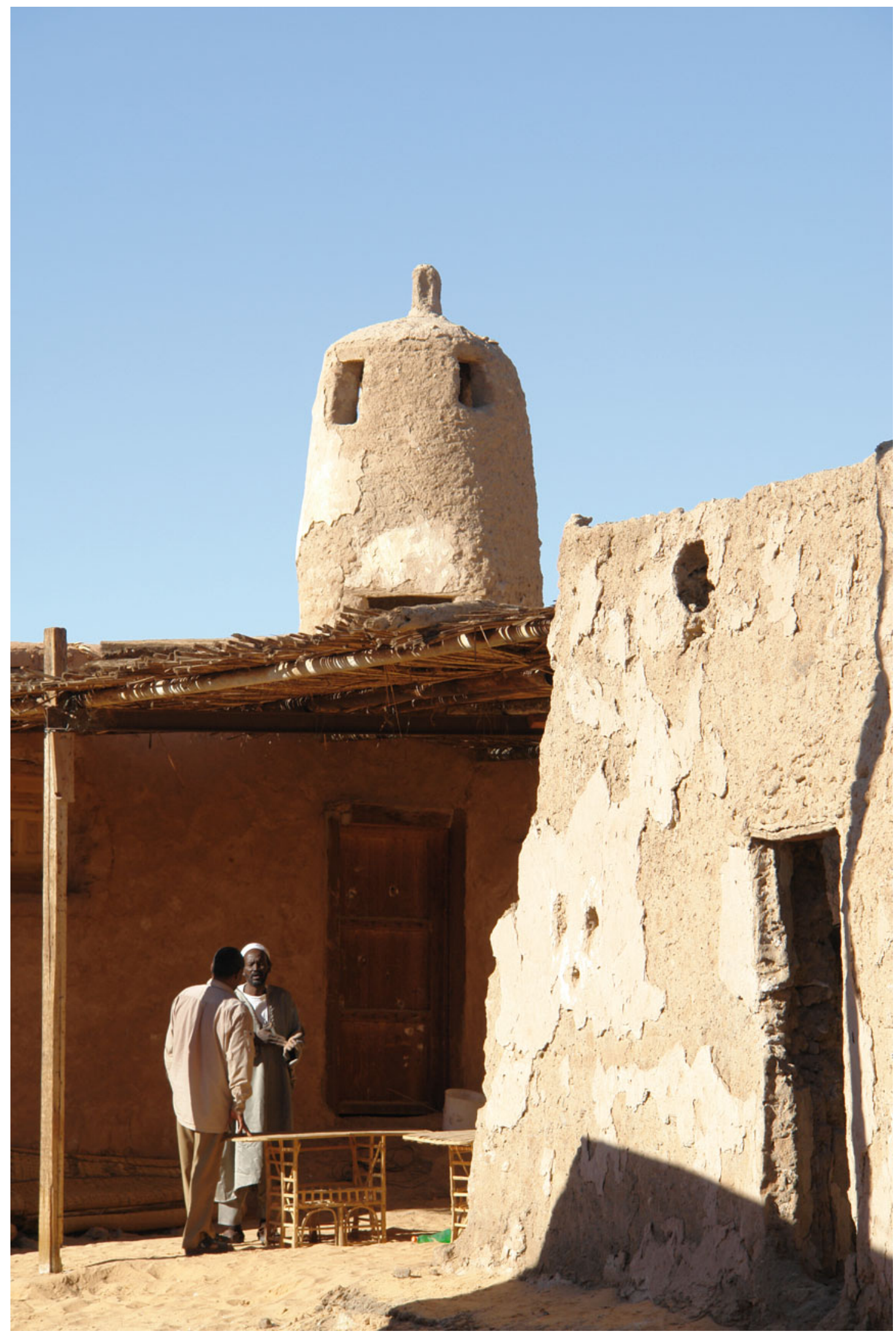

Fig. 6.70 Old town of al Qatrun: The people, who live there belong mainly to the Tubu tribes 


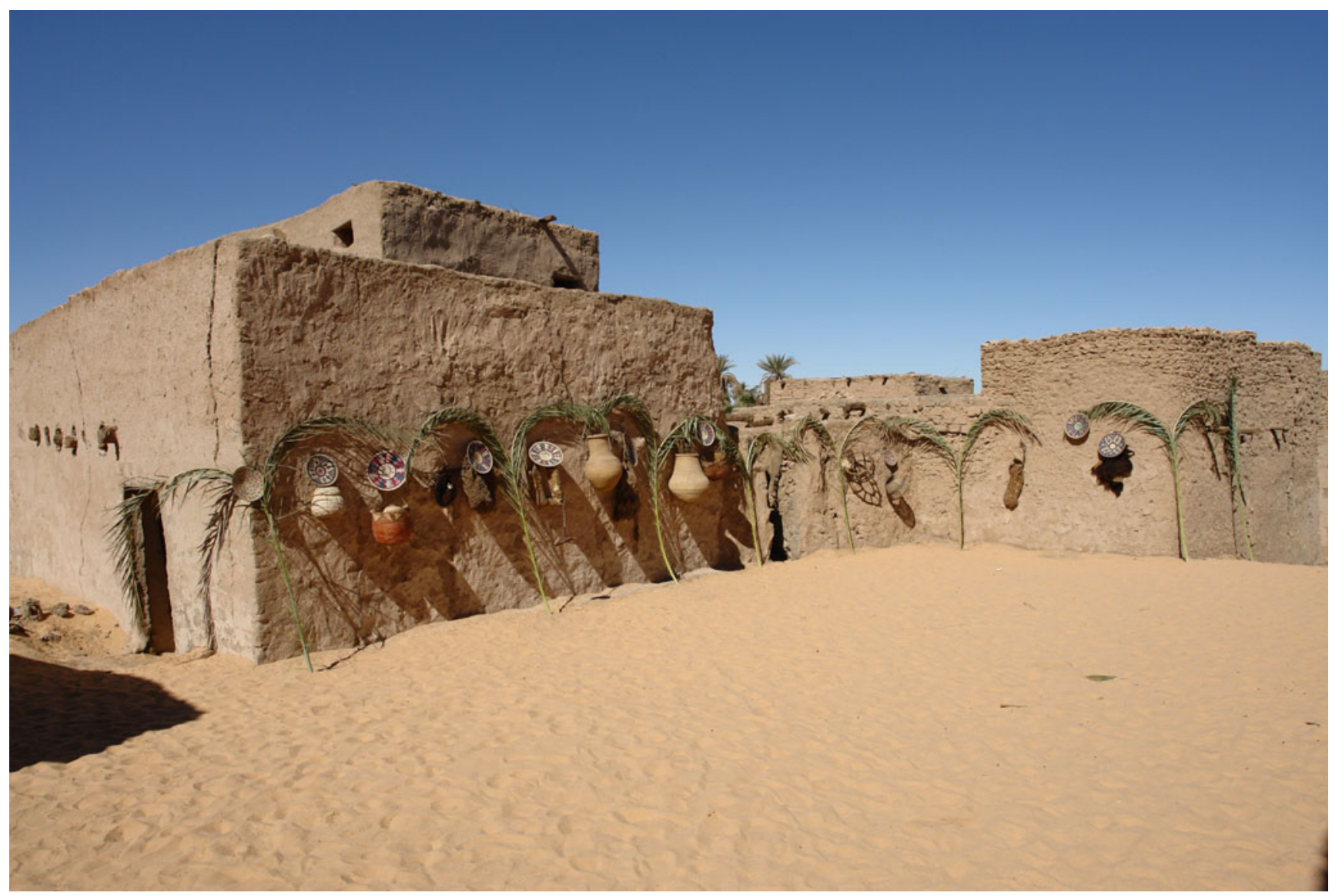

Fig. 6.71 Traditional objects are exhibited in the old town of al Qatrun

grasses also grow there and are grazed by camels and other domestic animals.

Dates were the most-traded product. They were produced locally and transferred to the Murzuq market to be sold to the passing caravans towards Tibesti, Zinder, Bardai, Timbuktu, Kanem and southwards to Lake Chad and the upper regions of the river Niger. By the beginning of autumn, large caravans used to come from the north to al Qatrun to exchange different kinds of local dates with the needed products in the area such as grains, spices and garments.

According to the census of 1954, al Qatrun's population was about 1654 persons distributed among four villages: al Qatrun (820 persons), al-Bakhi (510 persons), Madrusah (200 persons) and Tajarhi (124 persons). Most of the people depended on the traditional ways of field cultivation or grazing animals in a number of vicinal wadis. The people of the area also practised traditional handicrafts, which depended on local raw materials such as palm trees wood or fronds, pottery, wool and spinning and skin tannery (Fig. 6.71). Moreover, some of the inhabitants rent their camels to the traders. They also worked as Sahara route experts and as guides for the caravans. It is no surprise that a famous caravan leader, called Mohammed al Qatruni, has originated from that geographical area. He accompanied a large number of Arab and European travellers, and he was highly recommended by the German explorer Heinrich Barth.

The features of the people of al Qatrun and its neighbouring villages are similar to the people of Gabr Oun and some other villages of Wadi al Hayat, who inhabit the area of the sand dunes to the south of Wadi ash-Shati and north of Wadi al Hayat. There is a similarity between them and the people of Bornu; their tongue is Arabic with a lot of Berber and Kanori words.

Due to the rocky terrain, the rarity of water and the insecurity of the region, it was not easy to pass the area of al Gatrun. Even though the distance between Tajarhi and Majdul was guarded by several castles (qsur), caravans usually were attacked by Saharan raiders. To provide security and food to the caravans, many castles and wells were developed. Until now, some of the relevant evidences and remains are still visible in the area such as small mosques (usually of a row of stones with an apse at the eastern side showing the direction of holy Mecca), large stones which were used for fixing tents, sand-filled wells and damaged watching towers and forts which were used for guarding the caravan routes. ${ }^{129}$ 


\subsubsection{Tajarhi-the Most Remote Spot}

The oasis of Tajarhi is considered to be one of the most distant centres of culture in the Fezzan area. The small oasis is situated about $82 \mathrm{~km}$ south of al Qatrun at the intersection of latitude $14.20^{\circ}$ north and longitude $14.25^{\circ}$ east.

Tajarhi came into being in a small basin, on the edge of Idhan Murzuq in the depression of what the Italians called al-Hikma ('wisdom') valley. The locals attach this name to a small hill situated east of Qasrawa, located between al Qatrun and Tajarhi. The al-Hikma valley was considered among the poorest valleys of the Fezzan with regard to sweet water. Nevertheless, there was a water table at a depth ranging from one metre to three metres underground level from which the locals drew water using a counterpoised sweep for the irrigation of their limited cultivations. This water table made it possible for some grass to grow, serving as pasture for cattle. On the other hand, date palm trees were available in great numbers.

The leader Uqba ibn Nafi took control of the region in the year 664 in a campaign which led him as far as the fortresses of Kuwar. Probably, he chose the Tasawah road and the Taraghin regions in his quest to take over the fortresses of al Qatrun and Tajarhi. On this road, one finds easy paths and inhabited cities. In this manner, the Arabs came to learn the shortest way linking the southern Mediterranean cities to the sub-Saharan territories. Tajarhi's extreme location in the Libyan Desert rendered the oasis very important as a halting place for caravans coming from al Qatrun. In fact, Tajarhi was the last oasis of the Fezzan. One would leave it to proceed towards the city of Sajdin, in Kuwar, $580 \mathrm{~km}$ away. Caravans covered this distance in about fifteen days. When travelling in this region, the caravans had to exercise great caution. For two whole days after leaving Tajarhi, no water resources were available. After that, one could replenish one's water reserves from the Sharu well.

The Tubu communities called the southern Fezzan region "Zila" or "Zilan", particularly the area of al Qatrun, Tajarhi and Taraghin. This was the area from which one could reach Jadu, from Tajarhi, having travelled $550 \mathrm{~km}$. On this journey, one followed the Tummo and Madama road and crossed the Jadu hill, in a straight line. Caravans were able to cover this distance in 15 days. Some Tuaregs used a path from Ghat which went through Idhan Murzuq, reaching Tajarhi in a straight line. Some sections of this road were quite safe, but others were rather dangerous. In fact, large caravans did not take this road, and only those with few camels ventured through it.

Caravan trade, which linked the Mediterranean coastal cities to al Qatrun, Tajarhi and Kuwar, flourished during a period of stability and security in the region, particularly during the eighteenth and the end of the nineteenth centuries.
However, by the end of the nineteenth century and the beginning of the twentieth century, the situation had changed, especially after the French occupation of Chad and the opening of alternative roads, which saved traders both time and money. Moreover, the drop in the European demand for African products affected the region economically, until it became partially isolated. ${ }^{130}$

\subsection{Sirte (Sultan) — Custodian of the Gulf of Sirte}

\section{Said Hamid}

The old city of Sirte (nowadays called Sultan) is situated about $55 \mathrm{~km}$ east of the modern city of Sirte and about 520 $\mathrm{km}$ away from Tripoli in the west. It lies approximately halfway between Tripoli and Banghazi.

The old city of Sirte is situated in the great Gulf of Sirte, which is considered among the biggest land indentations that can be clearly seen in the African continent's coastline. It is suggested that this gulf was created in the wake of the collapse of land due to tectonic movements. These movements were linked with similar tectonic activity which gave rise to the Cyrenaican plateau in the East and the Tripolitanian plateau in the west.

\subsubsection{Important Commercial Spot by the Sea}

Sirte was built in the Middle Ages in the vicinity of the Roman city of Acena. It seems that this Roman city was built on the remains of the Phoenician port of Korax, which became famous after the establishment of the Phoenician city of Carthage in $814 \mathrm{BC}$, serving as a market for the commercial exchange between the Cyrenaican Greeks and the Carthaginian Phoenicians. The old city of Sirte was taken over by the leader Amr ibn al-As shortly before he took control of the city of Tripoli in 643. Probably, it was just a small city sustaining a limited population. The city's importance goes back to the tenth century. ${ }^{131}$ Back then the Arab geographer Ibn Hawqal noted: "[...] It possess more property, revenue, freewill offerings, grazing camels and cattle than the city of Ijdabya [Ajdabiya] in our time. It is rich in date palms from which ripe dates are picked [...] It has enough date palms, and it also has vines and fruits of reasonable price [...] Their imam undertakes the collection of their alms, taxes, and the dues payable by the passing caravans [...] Its revenue is greater than that of Ijdabya [...] Merchandise-carrying vessels also reach Sirte, and from it, Sirtian alum is exported, which is abundant in this region as well as wool. As regards goats are more abundant than sheep, and more useful. Its inhabitants drink rain water (which they gather) in cisterns."132 
The old city of Sirte witnessed considerable development during the tenth century, and it was very important commercially due to the region's considerable economic resources such as Sirtian alum, meat and wool. Moreover, its imam used to collect the legally prescribed alms tax and the land tax, apart from collecting the dues from the caravans passing through the city. Its harbour, notwithstanding its small size, contributed towards the flourishing of commercial activity. It was the port of small vessels which carried exported goods for exchange with local products.

The Fatimids recognised the importance of the old city of Sirte, especially at the time of al-Muizzli-Din Allah. That was because the city was located on the way leading to Egypt, against which he led his military campaign. In fact, Sirte fell on the shortest route between the city of al-Mahdiya (in Tunisia) and Egypt. For that reason, some fortresses, wells and cisterns were built, and Sirte's mosque was reconstructed. It became one of the most important commercial cities in the Gulf of Sirte because of its location, halfway on the route that linked Misurata and Ajdabiya on the one hand and the route linking the cities and oases of al Jufrah and the Fezzan territory to the northern coastal route on the other. In view of its vicinity to the desert, the travelling distance between Sirte and the Sub-Saharan
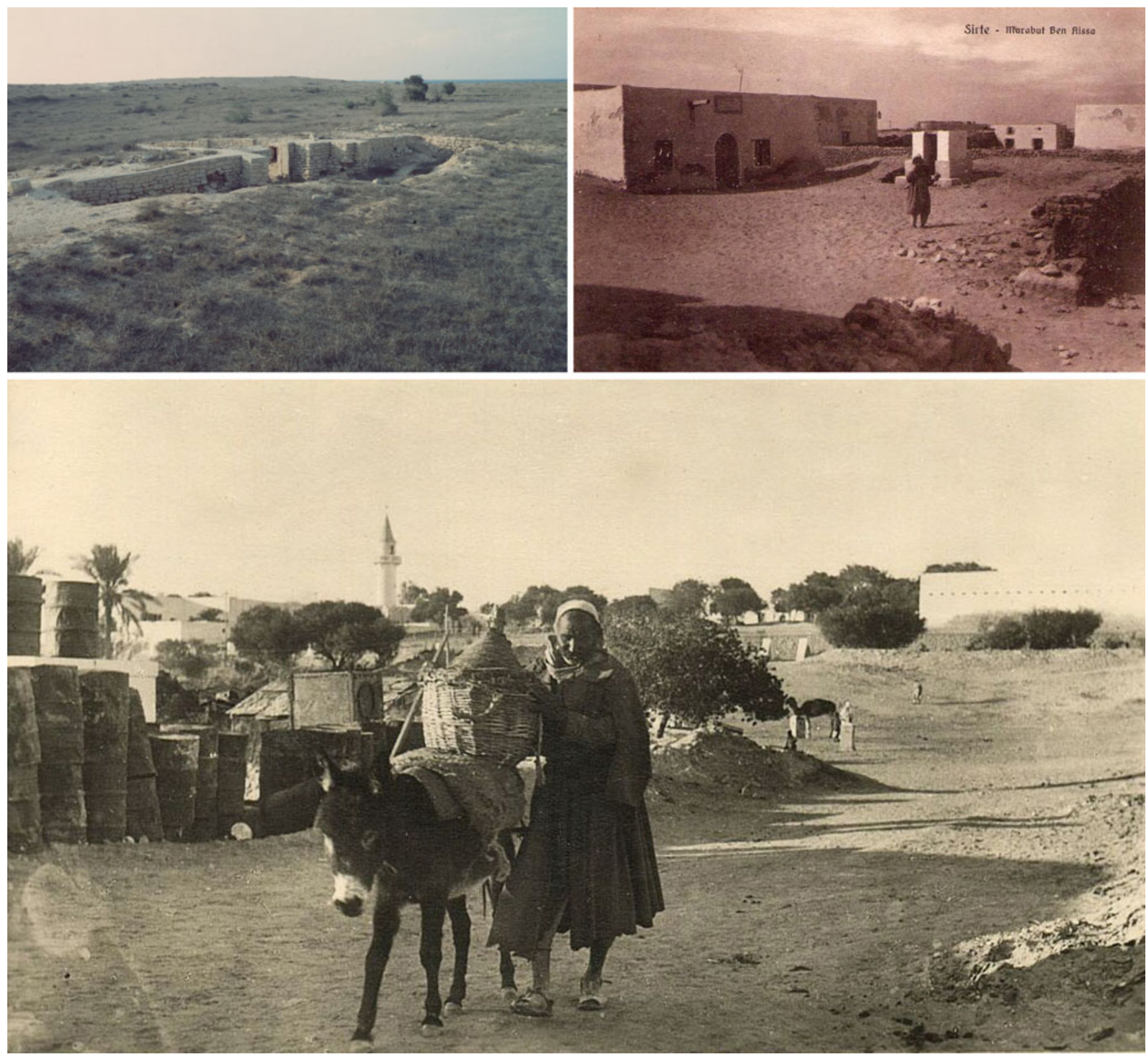

Fig. 6.72 Remains of the old city of Sirte (above left) and scenes from modern Sirte taken during the Italian occupation 
commercial centres was about one month less than the distance between those centres and other southern Mediterranean coastal cities. Moreover, it was situated on the northern coastal pilgrimage route. It had abundant water reserves stored in wells and cisterns, and the surrounding area was also rich in pasture for the caravans' camels. Among the most important commercial routes which used to pass through Sirte was the coastal route adopted by the North African and Moroccan pilgrimage caravans and travelling parties. It contributed towards the flourishing of commercial exchange between the inhabitants and the pilgrims' caravans. Bartering between the two sides was the predominant way of doing business. Some travellers describe how the people of Sirte resorted to some tricks in their commercial dealings with the pilgrims. For example, they would inflate water skins and hang them in front of their shops, giving the impression that oil was available in abundance. In this way, the price of oil would become cheaper.

The old city of Sirte was influenced by the events which took place during mid-eleventh century. The city and its region were exposed to the migration of the Banu Hilal and Banu Sulaym. Moreover, during the thirteenth century, the city as well as the routes leading to it suffered from chaos and insecurity that had resulted from the raids of the Qaraqosh and Bani Ghaniya armies. This brought about the loss of Sirte's commercial and economic importance. Furthermore, Sirte was linked to two main southern routes:

- Sirte, al Jufrah oases (Zillah, Waddan, Hun, Soknah), Tmissah and Zawilah. From here, two routes branched out: the first one towards Murzuq, Tasawah, Ghat, Zinder and Kano and the second one left al Qatrun towards Madrusah, Tajarhi, Kuwar and Kuka on the Lake Chad.

- Sirte to Tagreft, and from here two routes branched out: the first one towards Zillah, Tazerbu, al Kufrah, proceeded southwards towards al Fasher and the western cities of the Sudan. The second route proceeded towards Tagreft, al Fugaha, Tmissah and Zawilah. From here, one proceeded either to Murzuq, Ghat or towards al Qatrun and from there to Kuka.

\subsubsection{Modern City of Sirte}

As for the modern city of Sirte, which is situated at latitude $31.14^{\circ}$ north, and longitude $16.06^{\circ}$ east and located about 55 $\mathrm{km}$ west of the old city of Sirte, it was established during the second Ottoman period (Fig. 6.72). In 1842, the Ottomans built a fortress at Marsa az-Zafran (modern Sirte). This fortress was originally called az-Zafran palace, and later it was referred to as Sirte palace. In 1912, the Italians restored the old fortress, and the modern city of Sirte developed around it. Later, it became the most important resting and provisioning terminal for the westward and eastward routes. These routes followed either the northern coastal road towards Cyrenaica, Egypt and the Hijaz or westwards towards the Maghreb Arab countries and southwards towards the Fezzan and Central, West and East Africa. ${ }^{133}$

\subsection{Banghazi-Port and Trading Centre in Eastern Libya}

Najmiya as-Sadeq at-Tellisi

The city of Banghazi is situated about $1050 \mathrm{~km}$ east of Tripoli. It overlooks the Mediterranean coast and is located at latitude $32^{\circ}$ north and longitude $20^{\circ}$ east.

It is considered one of the most important cities in the north-east of Libya and the biggest among them, both in area and in the number of inhabitants. Banghazi is also considered the gate to the Green Mountains, which is characterised by its enchanting natural environment and by the various Greek and Roman archaeological remains.

\subsubsection{Port and Trading Centre}

The old city was one of the famous five Cyrenaican cities established by the Greeks in the year 446 BC. They named it Euesperides. The Libyan Pentapolis included Cyrene, Apollonia, Ptolemais (or Barca), Arsinoe (or Taucheira) and Euesperides (or Berenice). The settlement was located on the edge of a lagoon which opened from the sea. The name Euesperides is thought to refer to the mythological gardens of Hesperides. After Ptolemy III married Berenice, the daughter of the governor of Cyrene in 246 BC, the city was named Berenice after his wife. It was under the rule of Ptolemy that the entire city was moved to the present location of Banghazi. The move may have been triggered by the silting up of the lagoon. It later became a Roman city and prospered for 600 years. In the third-century $\mathrm{AD}$, the city became a Christian bishopric. The first of its bishops, whose name is recorded in extant documents, is Ammon, to whom Dionysius of Alexandria wrote in about 260. The base of all wealth and prestige of the city was the trade. Networks of trade linked ancient coastal Libya to the oases of the Sahara. ${ }^{134}$ The Arab conquest from 641 and 642 brought an end to the Roman world in Northern Africa. But the city ceased to exist. For several centuries, an Arab settlement prospered. Cattle, wool, honey, and olive oil were exported through the port of Ptolemais and overland by caravan. Sometime after 1050, the invasions of the Bedouin tribesmen of the Banu Hilal and Bani Suleim tribes ended sedentary life in the area. ${ }^{135}$ 


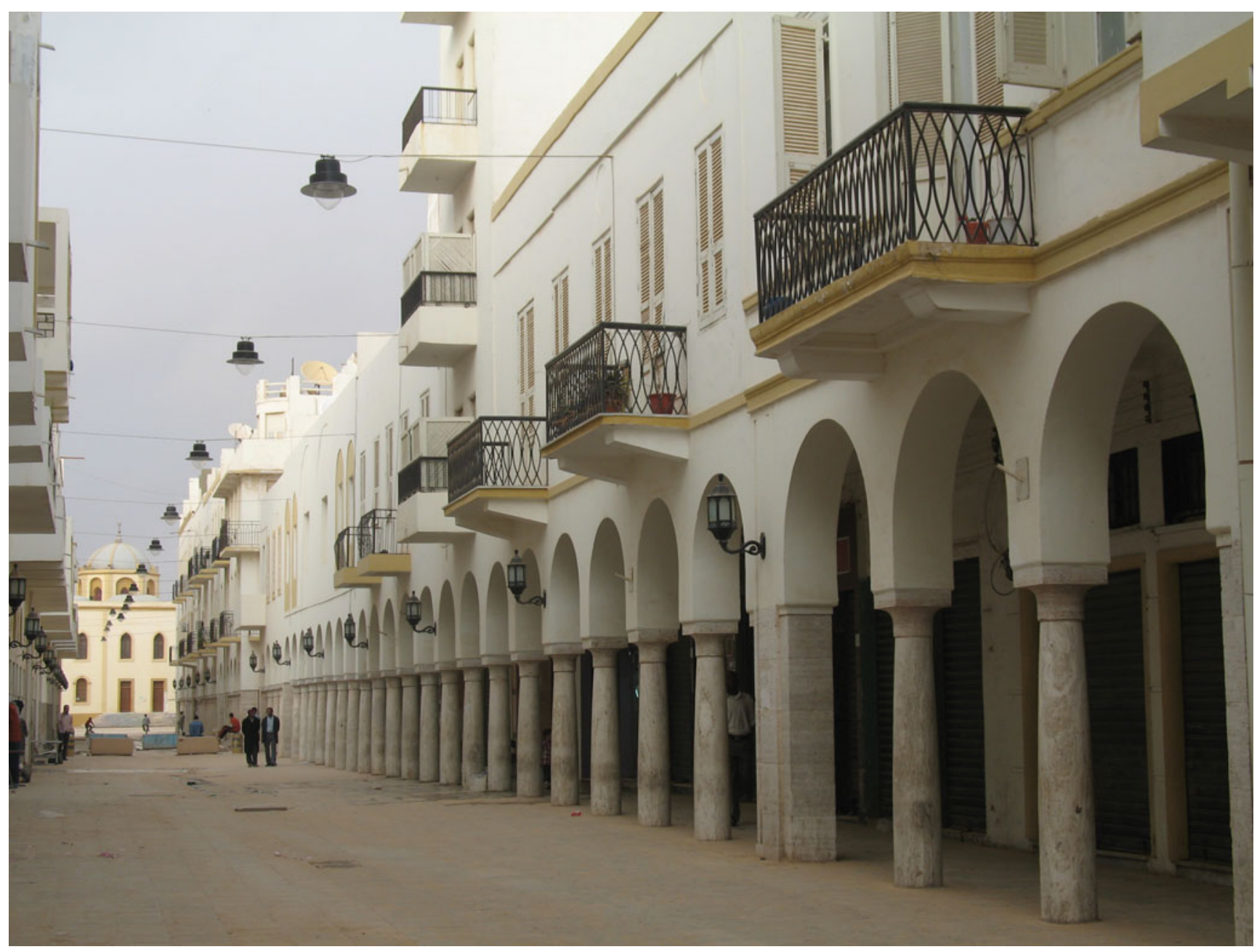

Fig. 6.73 Italian quarter was traditionally home to many people, before many families left the old town to resettle elsewhere in the city

Subsequently, the city was given other names, among them Koyat al-Milh. Ultimately, in 1450, when the governor as-Salih (Sidi Ghazi) settled here, the city was called Banghazi. It became one of the areas, which were submitted to Ottoman rule. In 1517, Cyrenaica became part of the Ottoman Empire, but at that time exercised little local control for the most part. It was in the beginning of the sixteenth century, that many Jews from Tripoli helped to repopulate Banghazi, earning their livelihood by trade with North Africa and the Mediterranean area. In 1635, at the time of Saqizli Pasha, a military campaign under the leadership of Othman Saqizli was sent against Banghazi with the aim of occupying it. Othman established a fortress (Fig. 6.74 (1)) overlooking the harbour, fully equipped with cannons, in order to control the commercial activity in the port. Later on between 1711 and 1835, the control of Banghazi passed on to the Karamanlis.

Time and again, Banghazi flourished both economically and culturally. This was due to the eminent role it played in commercial exchange, involving agricultural and animal produce as well as European and African products that reached its harbour. The city was at the crossroads of both maritime and caravan routes, the latter coming from the Sudan and Fezzan, loaded with different kinds of merchandise. This phenomenon rendered Banghazi a centre of commercial exchange and a base for the export of African commodities on the one hand and the importation of European products through its harbour on the other hand. In this respect, European states like England or France had signed commercial treaties to open consulates inside the Medina of Banghazi (Fig. 6.74 (3) (4)).

During the nineteenth century, it became an important outlet for the Saharan slave trade. There had been an ancient trade route between the eastern Sudan and Cyrenaica up to the Middle Ages. This route had been abandoned and came back into use in the early nineteenth century. Back then, the Wadai traders needed more outlets to Egypt and the Mediterranean than the route trough Fezzan offered. For this, they reopened this dangerous but direct road northwards via Kufrah and Awjilah. Slaves in the nineteenth century 


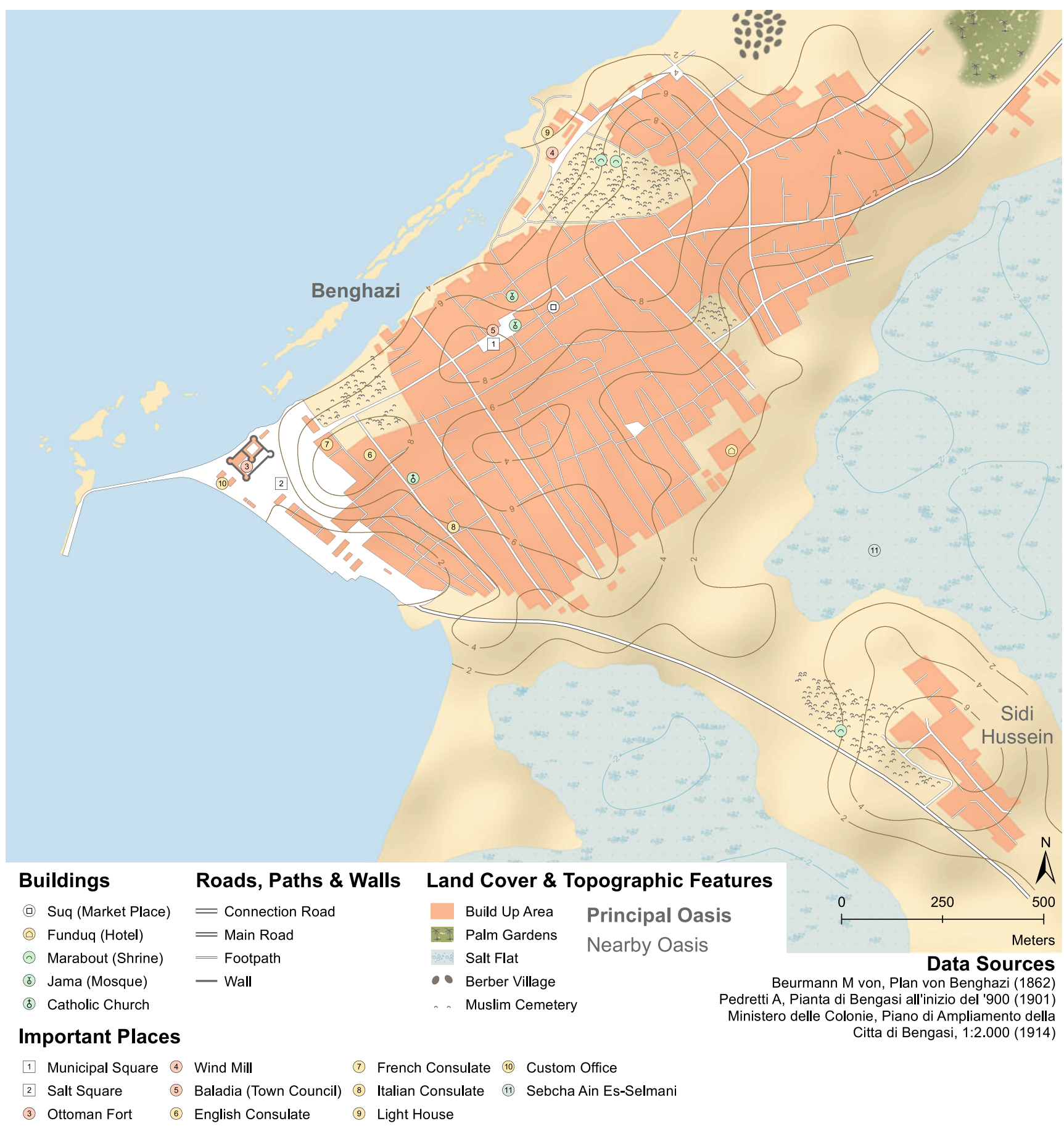

Fig. 6.74 Map of Banghazi

reached Banghazi from two main sources: from Bornu and Hausaland through Fezzan, and from Wadai through Kufrah. During the second half of the century, the Wadai road became even more important. Under pressure from the European states in terms to the abolition of slave trade, the Turkish measures in the $1850 \mathrm{~s}$ affected the slave trade through Tripoli massively. On average, about 700 slaves were shipped from Banghazi every year to the ports of Crete and Constantinople. The local demand in the city itself is estimated at 200-300 slaves a year.

The Wadai road remained active later than any other route connecting the Mediterranean littoral with the interior of Africa. It lasted well into the 1920s. What was important here was the fact that, until the fall of Wadai to the French in 


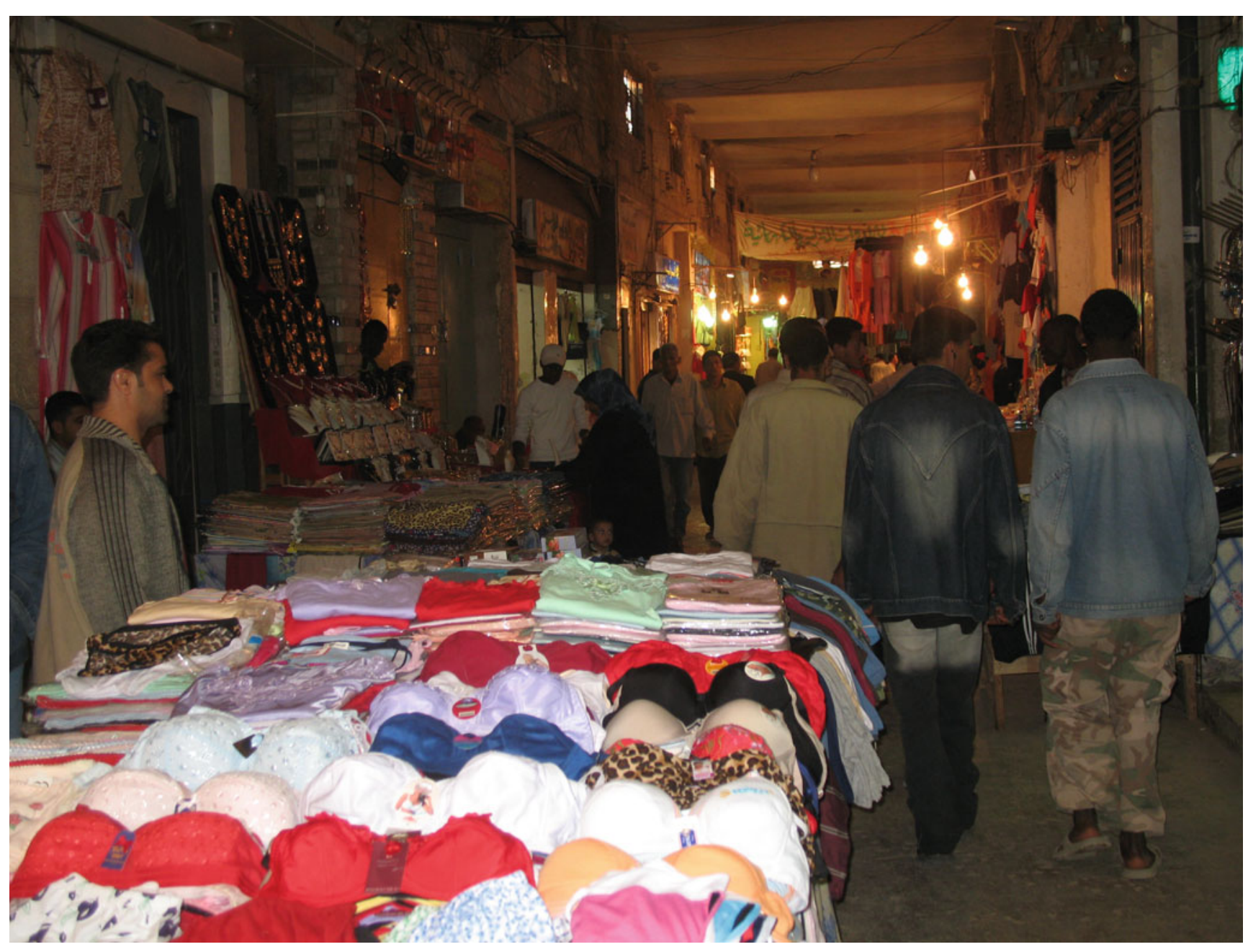

Fig. 6.75 Banghazi market in 2006

1909 and the Italian invasion of Cyrenaica in 1912-14, a single organisation maintained the Cyrenaican-Wadai road and provided merchants with legal stability, maintenance, security and shelter. That organisation was the Sanussiya brotherhood. $^{136}$

The city was also the destination of numerous European travellers, who documented their impressions about the historical and cultural sites they had visited. Grangier and Gerard (1675-1668) were among the most important travellers. Other visitors, who described Banghazi's main places of interest, were the Picci brothers (1821), Pascio (1825) or Ludwig Salvator (1873).

\subsubsection{Banghazi Markets}

The Banghazi markets were characterised by intense commercial activity during the passing of the pilgrims' caravans on their outgoing and incoming journeys to and from the holy lands (Figs. 6.75, 6.76 and 6.77).
Goods like cows, wool, cattle hides, barley and small quantities of grain were exported along these routes. Some central African goods carried by the caravans were exported to Malta. Other commodities such as butter, honey, wax, salt, for which Banghazi was famous, and some goods coming from the caravan trade, such as elephant tusks and ostrich feathers as well as slaves were exported to the eastern Arab countries. Moreover, Banghazi was also involved in bartering with the island of Crete and Tripoli. Cattle constituted an important segment of Banghazi's exports. Many Maltese and other ships used to call at the port of Banghazi to load cattle and cattle products for the European markets, particularly during the summer months. On the whole, Banghazi's traders considered trading in cattle a very profiting business, whenever suitable climatic conditions allowed the rearing of such livestock.

The events in sub-Saharan Africa, including its occupation and the opening of alternative routes as well as the Italian occupation (Fig. 6.78), influenced caravan trading negatively. As a result of these developments, Banghazi lost 

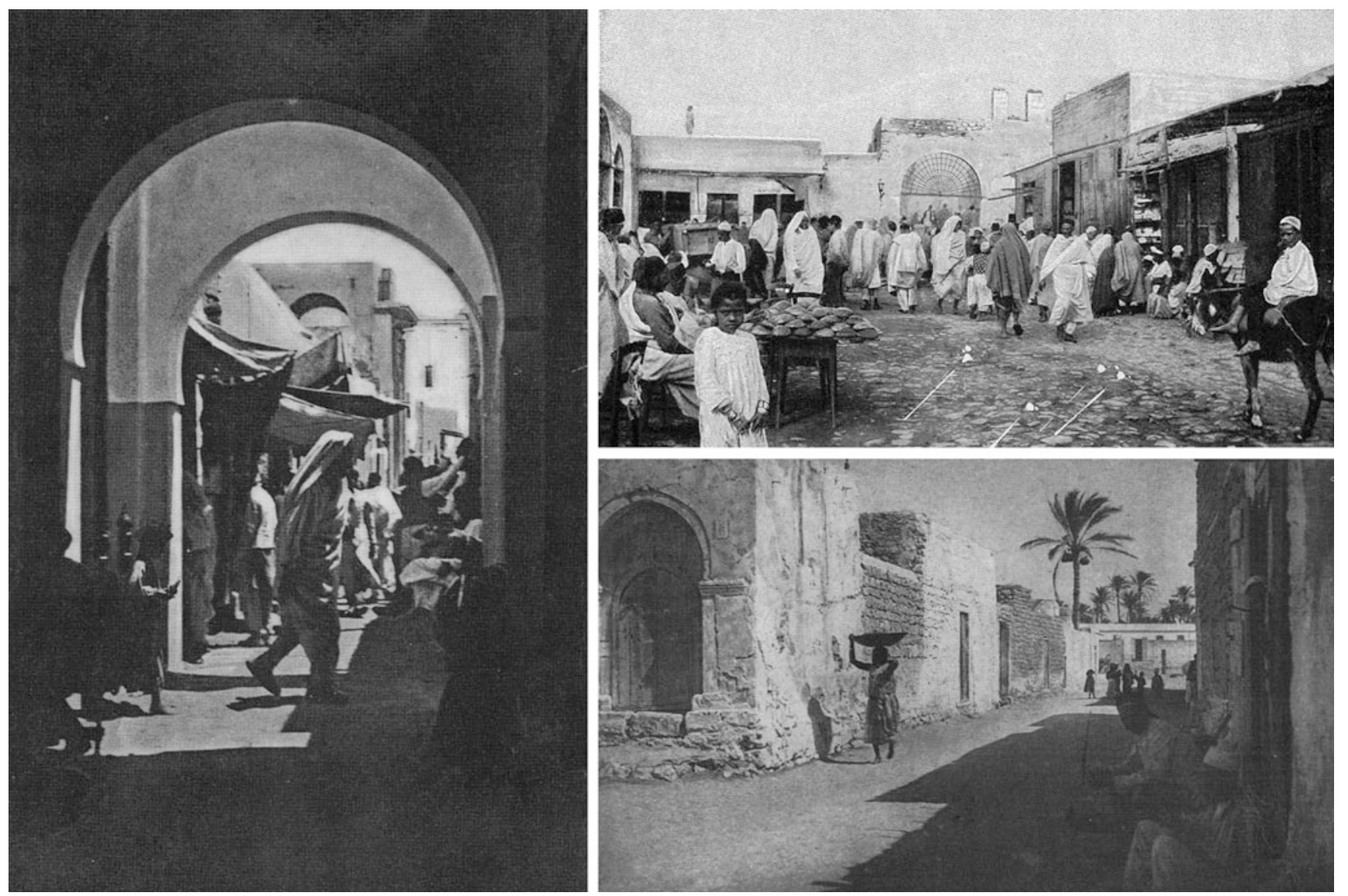

Fig. 6.76 Market scenes (photograph on the left Laronde 1997, photograph on top right Mathuisieulx 1912) and a street in Banghazi during the Italian occupation (Laronde 1997)

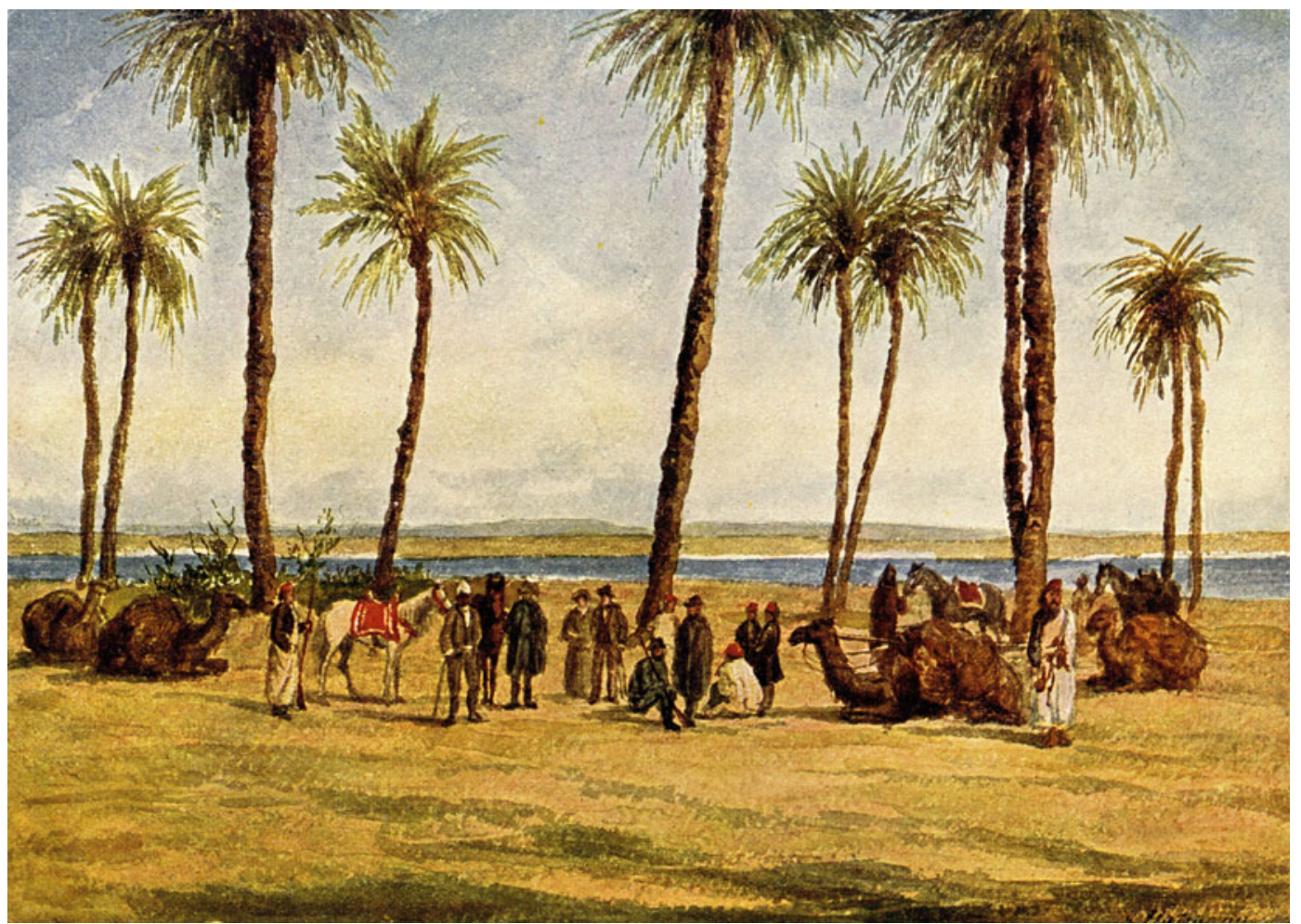

Fig. 6.77 A small caravan in camps near Banghazi on the 12 March 1881, as seen by the painter G. Haimann 


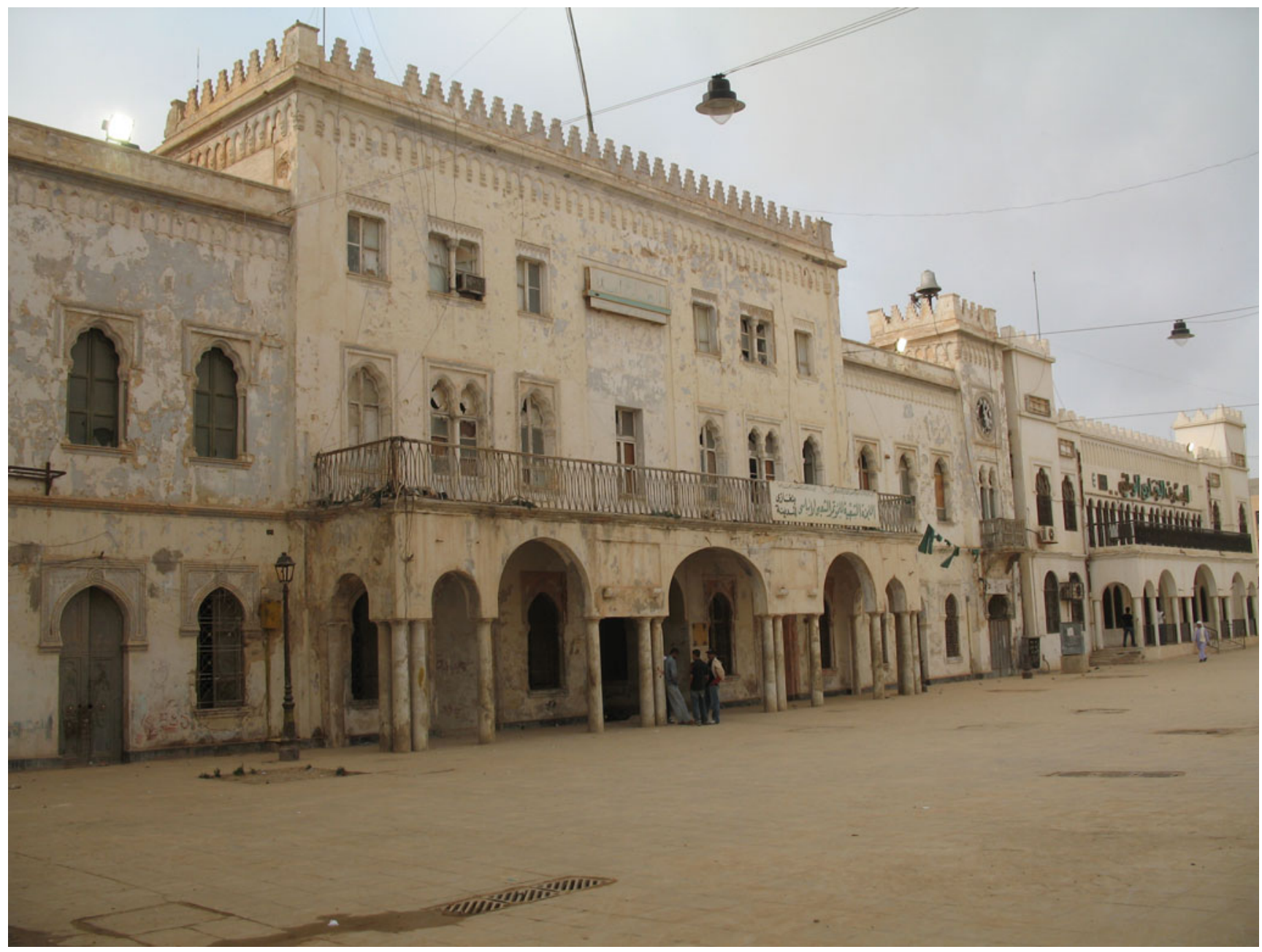

Fig. 6.78 Banghazi municipality is the former town hall of Banghazi (Fig. 6.74 (6), which was built in 1924. It is located in the centre of the Italian quarter in Maydan al-Baladia (municipality square). The building is the creation of several architects and designers. The portico of the facade and the interiors were designed by Marcello Piacentini, while the facades were designed by the architect Ivo Lebboroni. The interior frescoes are the work of Guido Cadorin, while the chandeliers are by Umberto Bellotto. The furniture inside the town hall was designed by the company Ducrot ${ }^{138}$

its economic importance. The commercial activity, which was the source of the previous affluence of the Banghazi traders, came to an end.

Banghazi was connected to numerous caravan routes directed towards Africa; the most important of which were the following:

- The Wadai route: This route departed from Banghazi and crossed the Awjilah, Jalu, al Kufrah and Tibesti oases. It passed by a number of wells, such as the Abu Tifl and the Zighan wells. The outgoing and incoming journey, including the various stops which were made, lasted about eight to ten months. Along this route, there were no inhabited areas, where one could find inhabitants renting camels or desert guides as was the case with the Ghadamis-Ghat-Murzuq route. Trade along the Wadai-Banghazi route flourished in the wake of the takeover of the Sudan by the followers of the Mahdi. Later, after the British occupation of the Sudan in 1889, this commercial activity declined, due to the transportation of exported products both on rivers and on railways built by the British in 1900 .

- Banghazi-al Jaghbub route: This route branched out in two directions: the western route, which was approximately $870 \mathrm{~km}$ long, was the preferred route. It presented no water problems, especially between Banghazi and Tilmun given to the existence of numerous wells. Among these wells, one could mention al-Khawabi, al-Gasiba, Umm Mabruka, Abu Idris or Saqiyat al-Baba. Those were shallow wells, ranging in depth between two and three metres. The Tilmun well had the sweetest waters, but it was rather deep. After Umm ar-Raha, one entered level ground, after which one would come across wavy sand dunes. This was a difficult tract, extending as far as 
the Matar valley. It was a low land with a deep well of sweet water. Beyond the valley, the routes came across the Hanaqiyya, Shaqiq and Hasi Hussein wells, which provided water to camels and horses. From there, the caravans used to reach the Asila oasis, situated in a low land with quicksands. Here, one found some wells such as the Tarfawi and the Abu Salama wells, whose waters caused diarrhoea. For this reason, the water was consumed, neither by men nor by animals, unless the caravan suffered from severe thirst. The eastern route comprised two wells, the Fastus and the Mazriq wells. In the tract between Banghazi and Fastus, there were some reservoirs in which rainwater was collected, supplying caravans with water. The most important were the reservoirs of the Hmarayn wells, situated deep in the desert, and the reservoirs of the al-Hakim wells, which collected rainwater mixed with mud. These waters were consumed by the caravans' camels.

- The Banghazi-Sudan-Chad route: This route was used to pass through Ajdabiya, Awjilah, Jalu, Zighan and al Kufrah. Caravan routes came together in this region, turning the oases into what looked like cities that offered various possibilities of rest, with markets fully supplied with different goods. In fact, this oasis region owed its rise to importance, as well as its later decline, to the caravan route. ${ }^{137}$

\subsection{The Islamic City of Barqa}

\section{Said Hamid}

The Islamic city of Barqa (modern al Marj) is situated in the area of the Green Mountains, about $100 \mathrm{~km}$ to the north-east of the city of Banghazi. It is located on longitude $20.48^{\circ}$ east and latitude $32.63^{\circ}$ north.

\subsubsection{A Place Full of History}

The old city of Barqa was founded at the time of Arcesilaos II, the fourth of the kings of Cyrene who ruled between 554 and 544 BC. The city witnessed various historical periods which characterised the area of Barqa including the Greeks, the Romans and the Byzantines.

Having conquered the city of Alexandria in the year 642, the Arab leader Amr ibn al-As wanted to continue his conquests in the region west of Egypt. The objective was to enable him to secure his position against the Byzantine threat as well as to spread Islam in new areas. After the Arab conquest, the region of Cyrene became known as 'Barqa' after its provincial capital. It enjoyed both security and stability at that time. During the early Islamic period, the inhabitants of Barqa were prosperous because the place was not controlled by any tax collector. The people of Barqa used to send the amount of the land tax at the right time. Abdallah ibn Amr ibn al-As is reported to have said: "Had it not been for my property in the Hijaz, I would have settled in Barqa. For I do not know of any place more secure and peaceful than this."

The city of Barqa (Fig. 6.79) is renowned for its fertile coast and it produced grain which used to be exported to Greece. In fact, the Greek historian Herodotus, who lived during the fifth century BC, praised the city's abundant produce.

During the early years of the Islamic period, Barqa became the capital of the region as well as an important commercial centre. Many Arab geographers and travellers described the city. One of them, al Yaqubi, mentioned the oasis in the ninth century in his Book of the Countries (alBuldan): "The city of Barqa is situated in a wide meadow. Its soil is of a very reddish colour. It has a wall, iron gates, and a ditch. al-Mutawakkil al Allah had ordered the building of the wall. Its inhabitants drink rain-water coming from the mountain, through the valleys, which is then collected in big cisterns commissioned by the caliphs and emirs for the benefit of the inhabitants of Barqa. The outskirts around the city are inhabited by different peoples. [...] Six miles separate the city of Barqa from the sea coast". ${ }^{139}$

Barqa is famous for being the first city which one reaches coming from Egypt. In his book The shape of the earth (Surat al-ard), Ibn Hawqal reports about Barqa: "[...] (in size) it is neither large, nor small. It has flourishing small towns. It is the first base which the traveller from Egypt reaches on his way to Qayrawan. It is constantly inhabited by strangers, because of the commerce which goes on in it, as well as by western and eastern visitors who pass through it on account of the tar commerce for which the city is famous, as well as for hides, which are then tanned in Egypt, and for dates from Awjilah. It has bustling markets selling wool, pepper, honey, wax, oil, and various products from the east and the west. Very often its food is abundant and cheap."140 The inscriptions and coins found in Barqa underline the city's significance during the early Islamic centuries.

Trade in Barqa started to shrink during the twelfth century, leading to a decline in its role and importance. In his book The pleasure of him who longs to cross the horizons (Nuzhat alMushtaq), written during the mid-twelfth century, al Idrisi remarked that the city had a small population at that time, its markets were depressed, and that in the past, the situation had been different. ${ }^{141}$ On his part, Ibn Said reported in 1250 in his Book of the Extension of the Land on Longitudes and Latitudes (Bast al-ard) that Barqa "[...] was the base of the Cyrene region which was much destroyed by the Arabs and is today called al Marj." The city, and the whole region in general, was exposed to the migration of the Banu Hilal and 


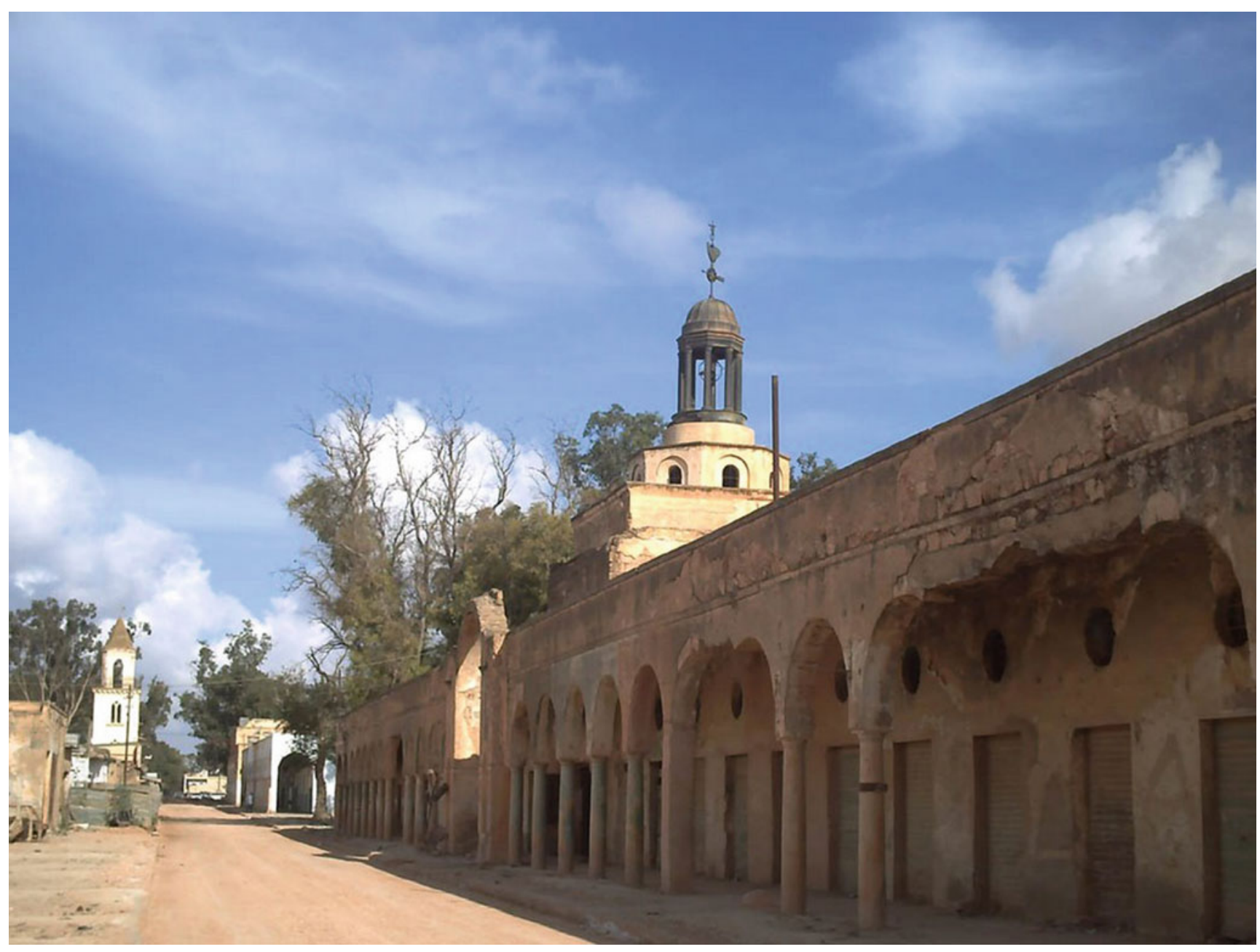

Fig. 6.79 Old town of al Marj (old Barqa) built in Italian style with churches and markets

Banu Sulaym tribes on the initiative of the Fatimid caliph al-Mustanir Billah, who, during the mid-eleventh century, allowed these tribes to cross the Nile on their way towards the Maghreb. This migration led to the destruction of Barqa, an event which was recorded by the historian Ibn Khaldun. A glorious phase in the history of the city had come to an end.

Barqa's position as a meeting place along the northern route of the pilgrimage to Mecca as well as its caravan routes was important factors that affected the city's prosperity. The desert caravans used to depart from Barqa on their way to Ajdabiya and from there to al Kufrah going south to Central and West Africa. It was connected with the Siwa oasis via the towns of al Mkheyli and the port of Marsa Lak near Tubruq, apart from being connected with Egypt via Derna and Alexandria. Barqa was linked to the Maghreb via Banghazi and Tripoli along the main road adjacent to the Mediterranean coast, apart from its connections by sea with Tripoli and other maritime cities via the port of Tolmeitha, which is situated about $20 \mathrm{~km}$ from the city of Barqa. Small ships could make use of this port during some periods of the year. ${ }^{142}$

\subsection{Ajdabiya-Important Trading Centre During the Early Islamic Period}

\section{Said Hamid}

The city of Ajdabiya is situated $160 \mathrm{~km}$ south-west of Banghazi, and it is $28 \mathrm{~m}$ above sea level and located at latitude $30.47^{\circ}$ north and longitude $20.12^{\circ}$ east.

Ajdabiya relies on underground wells situated in the sand dunes region for its water supplies. The city derived its importance from its distinct geographical location, enabling it to control the caravan trade routes directed south towards the Jalu and Awjilah oases and from there to al Kufrah and the Sudan as well as the coastal routes directed towards Sirte and from there to Tripoli and the Arab Maghreb. This was considered one of the most important caravan routes. It was also adopted by the pilgrims' caravans coming from Morocco. These used to stop at Ajdabiya both on their outgoing 
and their incoming journeys from the holy lands after performing the pilgrimage.

\subsubsection{Eventful History}

The origins of Ajdabiya are not very clear. The city seems to have arisen in Antiquity before the Roman occupation during mid-first century BC. Probably, its Roman name was Corniculanum, and it was included in Roman maps. During the first century AD, Syrian warriors established themselves in Ajdabiya. They used to defend the city and guaranteed the passage along the road from Cyrenaica to the Gulf of Sirte. Roman inscriptions on rocks have been found near old water wells, which testify to the Syrian presence. The Arab geographer al Yaqut al Hamawi refers in his book Mujam alBuldan, which he finished in 1228, to the name of the city of Ajdabiya, stating that Ajdabiya may be an Arabic name, being the plural of jadb that is "aridity". Moreover, it is probable that Ajdabiya is the Arabic name given to the city by the Arab conquerors upon capturing it. They had done the same with other cities which they had taken.

The city was captured by the Arab leader Amr ibn al-As in $642 \mathrm{AD}$. Upon entering into a peace agreement, the inhabitants of the city agreed to pay a tribute of 5000 dinars. Most of them embraced Islam. It was from this city that the Arab armies led by Amr ibn al-As departed on their way towards Tripoli and under the leadership of Uqba ibn Nafi headed towards the south in the direction of Awjilah and Zawilah. During the eighth century, Ajdabiya fell under the rule of Egypt. After the establishment of the Fatimid state, during the ninth century, the Fatimids started to focus their attention on the east, hoping to control Egypt. However, before doing so, they did their best to control the cities situated on the way leading to Egypt. The Fatimids were interested in the city of Ajdabiya because they soon became aware of its important commercial potential, as it was situated on the road linking North Africa to Egypt. In 966, the Fatimid caliph al-Muizzli-Din Allah started preparing his departure to Egypt. He arrived in Sirte on the "4th of Jumada al-Awwal" and then he left it, and stayed at the palace which was built for him in Ajdabiya. During his stay in the city, the caliph ordered the construction of reservoirs for the collection of rain water. It seems that the city prospered to some degree after the Fatimids started showing interest in it. Indeed, caravan trade flourished, and Ajdabiya represented the most important city in the Sirte region. It was linked to the Sudan via a route passing through Awjilah. After the death of al-Muizz in 976, the caliphate passed to his son al-Aziz Nizar. The latter confirmed Yusuf Bilkin as governor of North Africa and entrusted to him the territories of Tripoli, Sirte and Ajdabiya. Yusuf put into service his own agents in these cities, and his position was greatly enhanced. Later, the Zirid-Fatimid relations deteriorated, leading al-Muizz ibn Badis in 1049 to sever ties with the Fatimids and recognise the Abbasids. Consequently, the Fatimids supported the Arab tribes of the Banu Hilal and Banu Sulaym across the Nile and ordered them to move towards North Africa, promising them that the cities they conquered would become theirs.

Ajdabiya lost the prosperity it had witnessed during the early Islamic and the Fatimid periods. At the beginning of
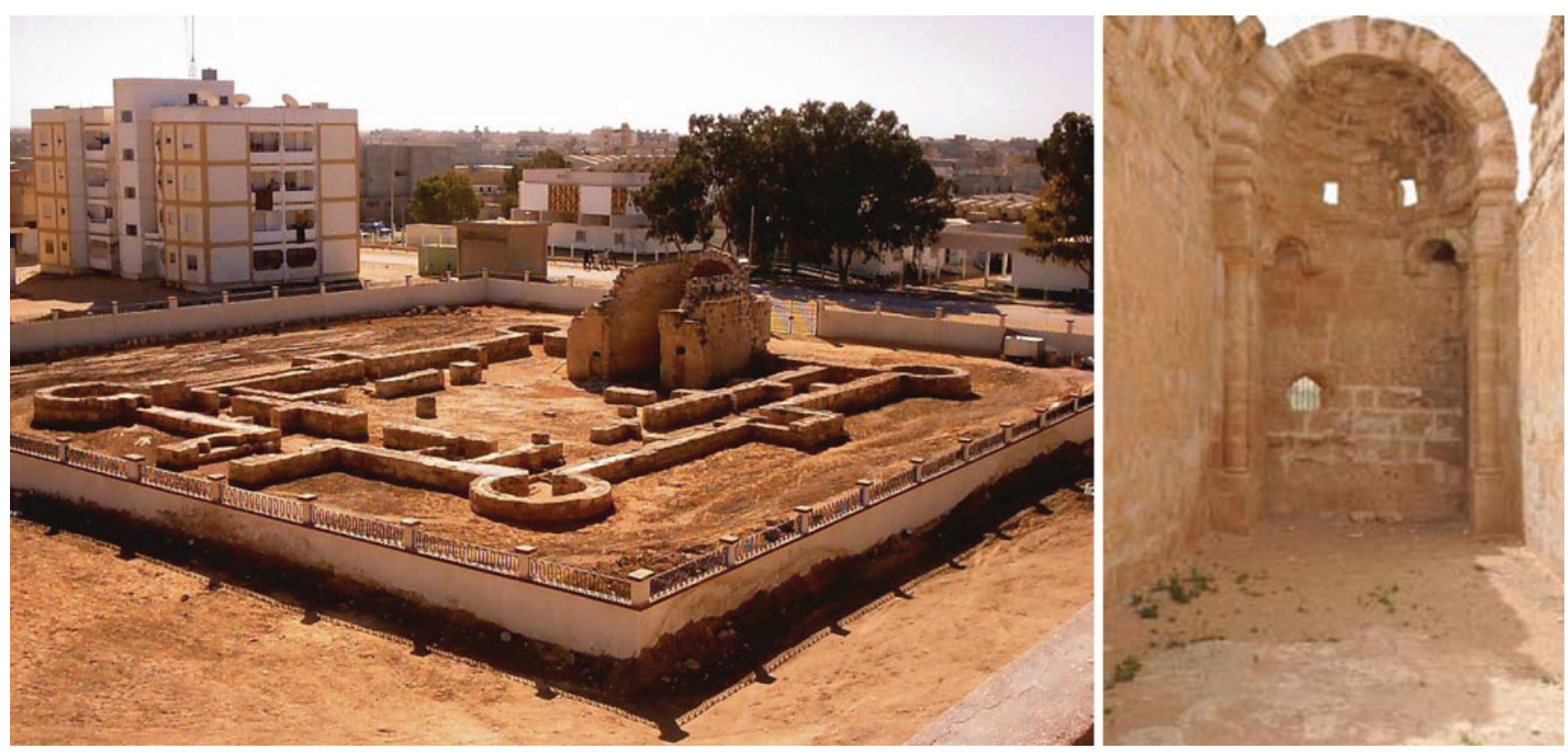

Fig. 6.80 There are archaeological remains of an old Fatimid mosque, which has been built on Roman ruins 
the Arab conquest, it was the place to which armies retreated and from which they departed on their campaigns. During the Fatimid period, it was an important commercial centre, and there were regions which belonged to it. In Ajdabiya, there was a fortress, a big mosque (Fig. 6.80) and a permanent market. It also had a harbour which was situated not far from the centre of the city.

\subsubsection{Written Accounts on Life in Ajdabiya}

Many Arab travellers and geographers have made reference to the city of Ajdabiya. At the end of the ninth century, the Arab geographer al Yaqubi described Ajdabiya in his Book of the Countries (al-Buldan) as "[...] a city above which there is a fortress. In it, there is a mosque and markets. From Barniq to Ajdabiya there are two stages, and it is four stages away from Barqa. It has regions and six miles of coast on the salty sea, in which ships cast anchor."143 The tenth century Muslim writer, geographer and chronicler Ibn Hawqal gives important details about Ajdabiya in his book The shape of the earth (Suratu l-Ard). From his description, one gets the impression that the place was a prosperous and heavily populated city. Its inhabitants were self-sufficient because of their orchards and date palms. Its governor assumed the collection of the alms, tributes and tithes as well as the fees from the trade caravans and sent them to the Fatimid caliph in Egypt. ${ }^{144}$ Abu Ubayd Allah al Bakri informs us about the condition of the city of Ajdabiya during the eleventh century. He states that "[...] it is a big city in the desert, its land is smooth, its wells are dug in the smooth rock, and their waters are good. It has a spring of sweet water, as well as beautiful orchards and abundant date palms. It has only Arak trees. In it there is a beautifully constructed mosque built by Abu l-Qasim ibn Ubayd Allah. The mosque has an octagonal minaret built with great skill. The city has many baths, inns and well-supplied markets which are well-frequented by customers. Its inhabitants are well-off. It has a harbour known as al-Mahur [...] Prices are not expensive, and its abundant dates, of different kinds, come from the city of Awjilah."145 Whereas al Idrisi describes Ajdabiya during mid-twelfth century as "A city in plain land, made of even stone. It used to have a wall. Now, only two fortresses remain in the desert. The sea is four miles away from it. There are no girls in it, nor around it, and most of its inhabitants are Jewish and Muslim traders [...] In Ajdabiya and Barqa there is no running water. For water, they rely on cisterns and waterwheels, enabling them to cultivate small quantities of wheat, and especially barley, some types of corn and other grains." The traveller al Abdari confirms the level of desperation that Ajdabiya must have been enduring his trip in 1289 and states that "... it has an old fortress, the size of a high house. Some historians mentioned that it had running water and date palms. But now, there is only a fortress in the open country, and there is neither running water, nor a single tree." There is much historical evidence attesting to the decline of the area and to its loss of its commercial importance. Many of its inhabitants abandoned Ajdabiya because of the lack of security and stability. Its farms and orchards were vandalised by adventurers like Karakosh and Yahya ibn Ghaniya. Their actions had indirect repercussions which were even more dangerous than their actual vandalism. This picture about Ajdabiya presented by al Abdari is the last one we have from the Arab geographers and travellers.

During the nineteenth century, the city of Ajdabiya was completely abandoned. It was not until the twentieth century, in 1921, that the place started to be repopulated and became again one of the most important cities of the Gulf of Sirte. Among the most important archaeological remains, which are still to be found in the city, are the Fatimid palace that was built prior to the departure of the Fatimid al-Muizzli-Din Allah to Cairo. There is also a mosque attributed to the Fatimid caliph Abu 1-Qasim ibn Ubayd Allah (1528-1539). Since 1971, the archaeological department in collaboration with the Society of Libyan Studies in London has carried out digs at the Sidi Hasan cemetery in Ajdabiya, which brought to light most of the remains of the old mosque (Fig. 6.80). ${ }^{146}$

\subsection{Awjilah-One of the Old Libyan Cities}

\section{Salih al-Mahdi Khalifa}

The city of Awjilah is situated in the south-east of Libya deep in the desert. It is situated $250 \mathrm{~km}$ south of the Mediterranean coast in a small, semi-closed basin within the northern section of the Wahat Great Depression. Awjilah is located at latitude $29.20^{\circ}$ north and longitude $21^{\circ}$ east.

\subsubsection{Economic and Scientific Centre in the Midst of the Desert}

Awjilah is considered one of the old Libyan cities (Fig. 6.81). Its name is featured in ancient Egyptian, Greek and Roman sources. In fact, Egyptian hieroglyphs going back to about $1200 \mathrm{BC}$ indicate that the inhabitants of the region, including the tribe of the Nasamoneans, extended from Banghazi and the Gulf of Sirte in the north and even penetrated southwards as far as the oasis of Awjilah. Herodotus, who lived in the fifth century BC states, that in summer the Nasamoneans used to leave their herds on the coast and travelled towards the interior to a place called Awjilah in order to gather dates. Date trees of the best quality abounded in that region. Moreover, Herodotus also referred to desert routes and geographical discoveries made 


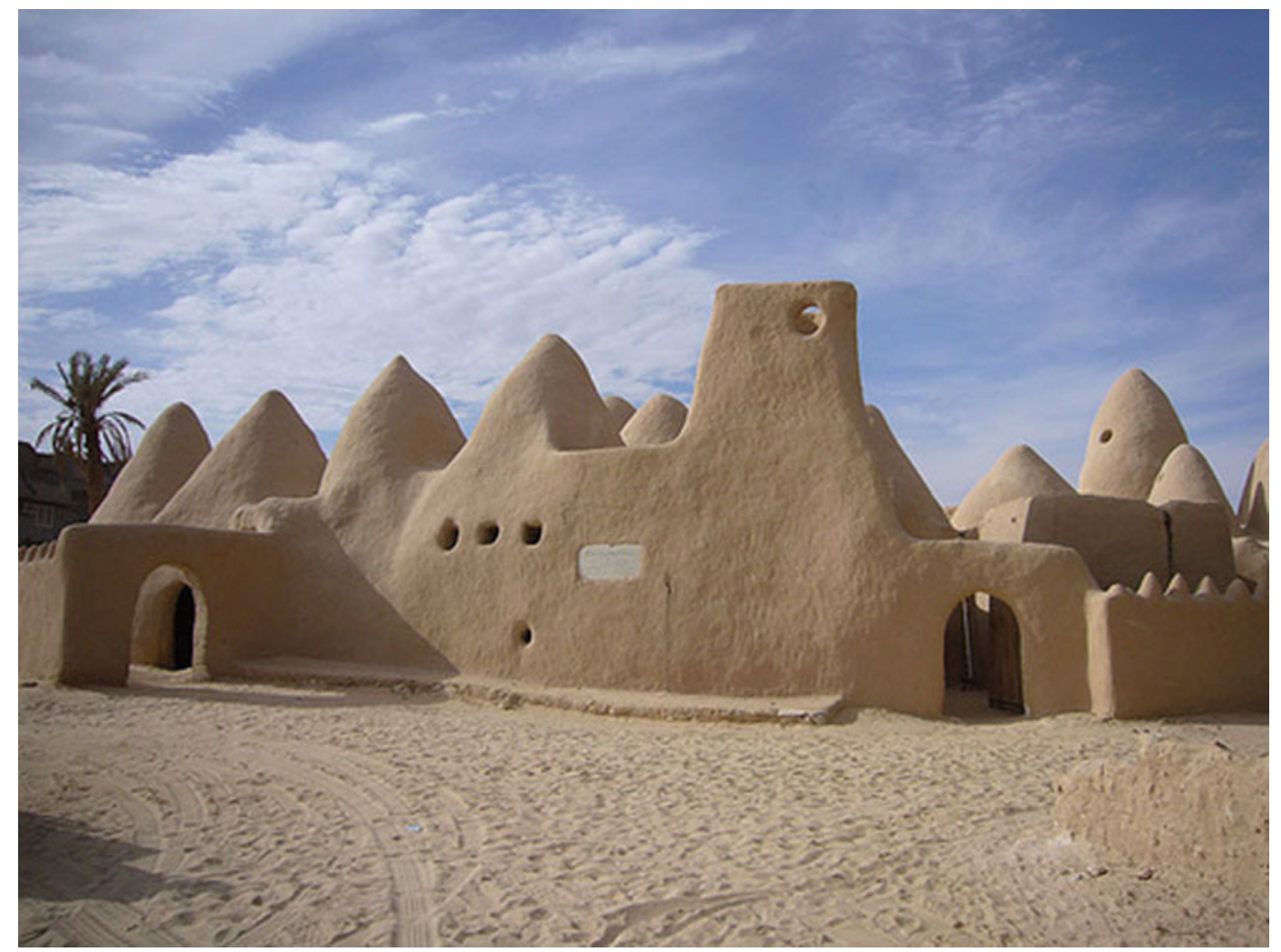

Fig. 6.81 Great Mosque of Atiq is the oldest mosque in the region. The present building dates back to the twelfth century

by some Libyans in the desert, in a country which nowadays is called Chad. In 643, Uqba Ibn Nafi conquered the Awjilah oasis and spread Islam in the surrounding regions.

This oasis drew the attention of a number of Arab and foreign travellers among them Ibn Hawqal, a famous geographic author of the tenth century. He described the oasis as "[...] an area with great date-palms and dates". al Bakri wrote in the eleventh century that the city was opulent and prosperous, with plenty of date palms. al Idrisi, who lived during the twelfth century, was of the same idea. In his book, A description of Africa (Wasf IfriqIya), al Hasan al Wazzan refers to the cultivation of date palms in Awjilah. Some historians regard the city as having three distinct agricultural areas, namely Mazuz, as-Swani and Awjilah. Marmol, the Spanish traveller, who visited Libya during the last third of the sixteenth century, stated that Awjilah was situated on the main pilgrimage route, linking Mauritania, Shengit and Egypt with the Hijaz. It was only natural that, with the flourishing of agriculture, caravan commerce was bound to thrive. In fact, in the first third of the seventeenth century Ibn Mlih stated that "... its welfare is abundant, because sustenance comes from far-away countries". ${ }^{147}$ On his part, the German traveller Rohlfs visited Awjilah twice, in 1869 and in 1879 .

He tried to monitor the commercial activity during the ten-year period which had elapsed since his first visit to the city. During the second visit, Rohlfs registered the changes witnessed in Awjilah. Regarding the number of mosques, for example, in 1869, he noticed that the oasis housed one big mosque and four small ones, whereas in 1879 there were thirteen mosques. Rohlfs confirmed Bashu's, Hamilton's and Hornemann's description of Awjilah and stated that he had nothing to add. He also observed the arrival of a caravan from Wadai, led by the brother of Ali Gurgi from Tripoli and stated that the arrival of caravans brought about a change in the way of life of the city. ${ }^{148}$

Awjilah's location, south-east of Ajdabiya and Banghazi, west of al Jaghbub and Jalu and east of Maradah, put the inhabitants of this oasis in an advantageous situation. This location enabled them to establish economic and commercial links with the internal regions of Libya as well as with the sub-Saharan African countries. Moreover, the city's location in the midst of the desert, faraway from the coast, protected it from the centres of conflict and from the great naval powers, such as the Phoenicians, the Romans and the Byzantines. This contributed towards the political, economic and social stability, growth and prosperity of the oasis. Furthermore, its distance from the main cities, such as Banghazi, Tripoli, Sabha, Darnah, Misurata and Sirte, which had witnessed a number of armed uprisings, was not quelled before the Ottoman Turks suffered great losses. 
In view of Awjilah's location, at the crossroads between the north and the south, the east and the west, the city became a meeting place for traders and men of science. Its markets were full of African products, including gold, silver, ivory, hides, ostrich feathers and other products. Products from the north, including textiles, utensils and agricultural products were also available in these markets (Fig. 6.82). The oasis attracted traders, people of science and pilgrim caravans, transforming Awjilah into an economic and scientific centre.

\subsubsection{Commercial Activity of the Oasis}

Since Antiquity, Awjilah has been also renowned for its groves of date palms and the availability of good quality dates of different types. This has enabled Awjilah to supply different areas with dates. The people of Awjilah were good-mannered, honest and truthful in their dealings, as well as multilingual. In fact, most of them spoke more than one language or dialect such as Arabic, the Kano language, Hausa and dialects of central Sudan and of the Tuareg regions. These linguistic abilities facilitated their understanding of African peoples. Moreover, traders from Tripoli and Banghazi relied on the people of the oases, including Awjilah, to guide and defend their commercial caravans through the deserts. Apart from agriculture, the inhabitants of Awjilah engaged in other professions, the most important of which being trade, camel breeding and lending as well as guiding caravans due to their knowledge of the desert and its paths. ${ }^{149}$ They taught their children the art of trade, as confirmed by the traveller Hornemann who stated that: "From a tender age, men dedicate themselves to trade. I have witnessed children of thirteen or fourteen years accompanying, on foot, the caravan on its long and strenuous journey from Awjilah to the Fezzan, hardly ever riding horses or camels". 150

The commercial activity, including the long yearly journeys to and from Awjilah, left its social and cultural marks on the city. On the social level, commerce influenced the social make-up of the inhabitants of Awjilah, as a result of intermarriages between the locals and people from other regions, who settled in the city. Culturally, the inhabitants of Awjilah, who came into direct contact with foreign people, were able to observe these ways of life and culture and were influenced by them. Some of its people became poets, indigenous scholars and judges.

The inhabitants of Awjilah relied upon the waters from the many wells in their region. In 1934, there were 270 wells of which 140 were fit for drinking. The other remaining wells were reserved for consumption by the livestock. Among the most famous wells, one comes across Zaydan well, Hayawan well, Tughut well, Awslam well, Ahmad Abu Silsla well, Diryana well, Sabil well, ar-Rasm well and ar-Rakb well. The latter is considered among the oldest wells, and according to tradition of the people of the oasis, it was dug out at the time of the beginning of the Islamic conquest. It is considered an important stage on the caravan route because here, in the middle of the desert, one can supply oneself with fresh water. The pilgrims' caravans coming from Morocco on their way to the Hijaz adopted this well as a reference point. It has been called ar-Rakb because of the great number of caravans which frequented it.

\subsubsection{Decline of the Oasis}

News about the control of the Awjilah inhabitants over the caravan routes and their prosperity reached the governor of Tripoli, Muhammad as Saqizli, who entered into agreements with the rulers of the Fezzan, Bornu, Timbuktu and Wadai. These, in turn, had commercial relations with the people of Awjilah. With the aim of monopolising the caravan trade, the governor instructed Othman as Saqizli, the leader of his army, to carry out a military campaign and occupy Awjilah in 1633. Through deception, he managed to arrest Ahmad Abd al Hadi and his family, tracked the merchants, robbed them of their money and threw them in jail. Moreover, he plundered Awjilah's gold and silver and imposed heavy taxation on the population. With the great amounts of gold, silver and taxation money, Muhammad Pasha as Saqizli was able to mint the coin known as the Qarmil, each Qarmil being equivalent to half a Dirham. This coin continued to be in circulation in Tripoli until the minting of another coin by Khalil Pasha. So much wealth was amassed, that Tripoli witnessed a boom in construction. It was at this time that the Othman Pasha as Saqizli school, the Grand Hammam (public baths) and other construction projects were carried out. The Ottoman campaign against Awjilah, the imposition of heavy taxation and Ottoman injustice and oppression resulted in most inhabitants emigrating from the oasis. This led to the oasis losing its identity as a commercial and administrative centre. Consequently, Jalu assumed the role of the main commercial centre in the region. In addition, the distinctive geographic location of Awjilah led its people to establish economic and commercial ties with various cities of the desert, making Awjilah a transit centre for the caravan trade. Among the most important routes which cross the region and link Awjilah to the Mediterranean coast are:

- The Hijaz route, otherwise known as the pilgrims' route: This route was taken by people coming from Algeria, Morocco and Mauritania. It passed through places as Ghat, Awbari, Sabha, al Fugaha, Zillah and Maradah until it reached the Awjilah oasis. From there, it 


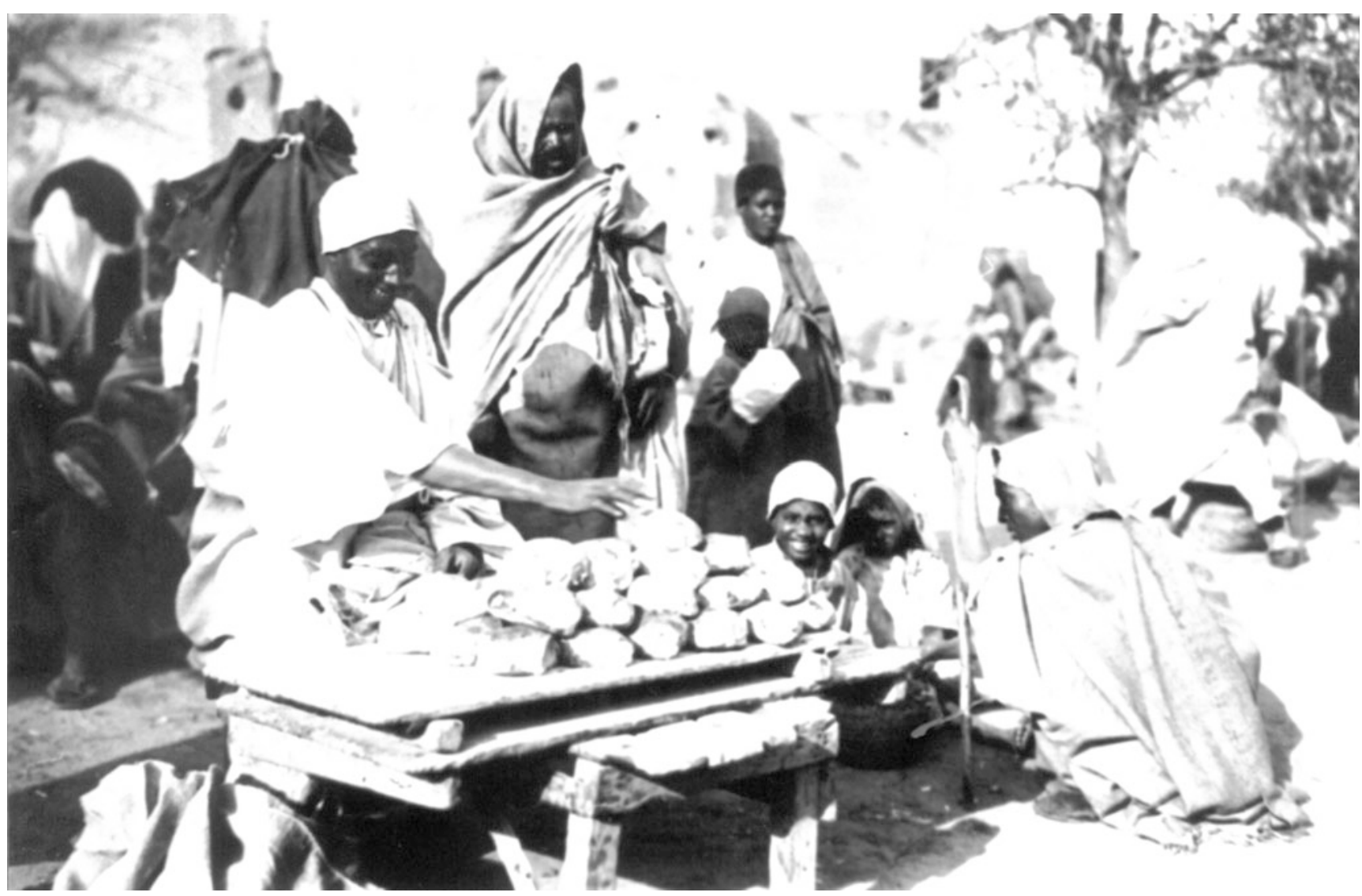

Fig. 6.82 Market scene from Awjila

progressed towards al Jaghbub, Egypt and finally the holy lands. What made this route distinctive is that it abounded in water sources and in fertile lands, thus providing the caravan camels with pasture. Moreover, there were many desert animals ideal for hunting, such as the gazelle, the Waddan goat and rabbits. This solved the problem of supplying oneself with food supplies. However, the fact that this route very often went through rocky areas made travel time-consuming.

- The Cairo route through al Fayyum, Siwa to the Awjilah oasis, and from there to Tripoli, Ghadamis and westwards across Twat towards the city of Timbuktu.

- The Awjilah-al Kufrah route reaching Wadai through Tmissah, Zawilah and Kuwar.

- The route which left Banghazi towards Awjilah, Jalu, al Kufrah, Tibesti, Anjuanja, Iski until it reached Wadai.

- The desert route left Tripoli towards Tarhuna and then Bani Walid. At this point, the route intersected with the pilgrims' route at Jufrah. From there, the route proceeded towards Zillah, Awjilah, al Jaghbub and Siwa, and from there across the Sinai Peninsula towards holy Mecca (Fig. 6.82). ${ }^{151}$

\subsection{Jalu_Important Crossroads in Eastern Libya}

Najmiya as-Sadeq at-Tellisi

The oasis of Jalu is located south-east of the city of Ajdabiya which is about $250 \mathrm{~km}$ ahead. Moreover $30 \mathrm{~km}$ north-west of Jalu, one finds the famous oasis of Awjilah. Jalu is located at latitude $29.02^{\circ}$ north and longitude $21.33^{\circ}$ east.

Geographically, the city of Jalu is situated in the middle of the north-east region of the great oasis depression. The Jalu basin is about 30 metres lower than the surrounding land. In its centre, there is the so-called Nakhfush valley. The southern section of this valley is called Dweylith-Thalab that is "the small tail of the fox". Here, the valley becomes somewhat wider. Extensive parts of the valley bed are covered with stones and pebbles which, in some areas, are mixed with sand formations. In other areas, sand dunes encircle the basin, particularly on its eastern and southern part. ${ }^{152}$ 


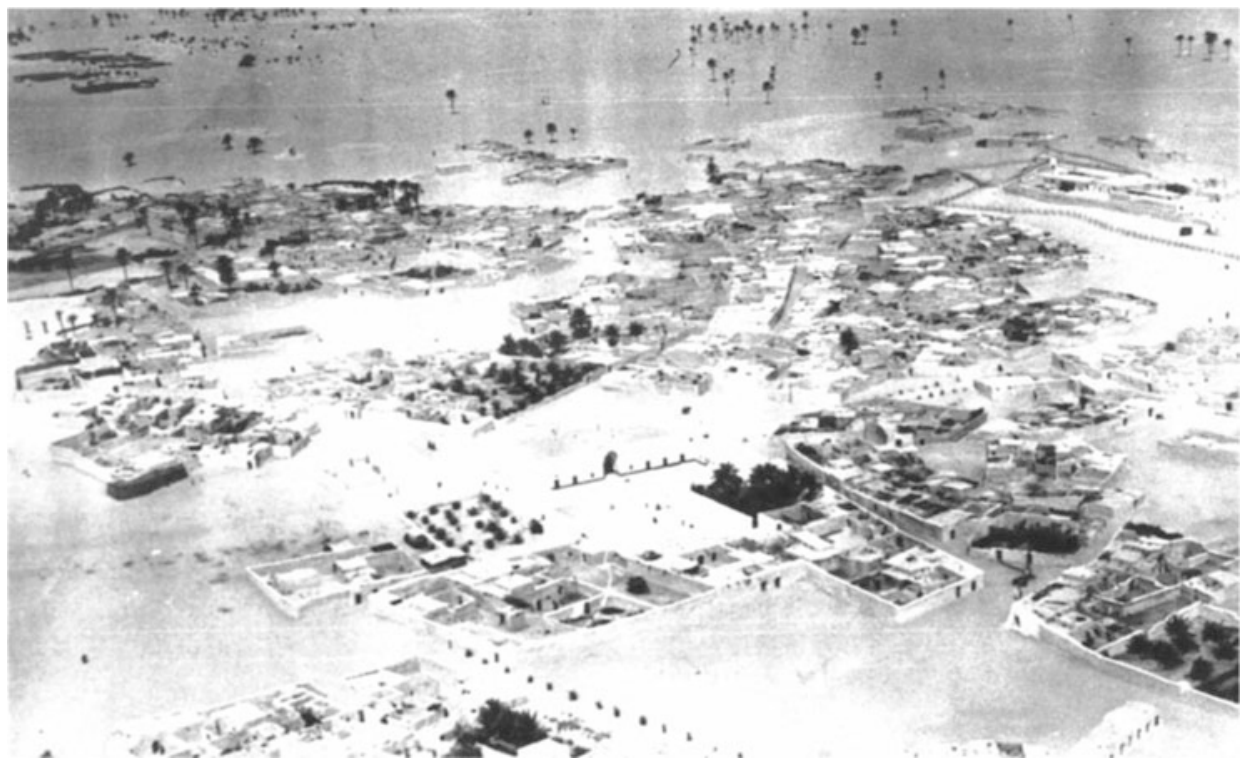

Fig. 6.83 Areal view of Jalu

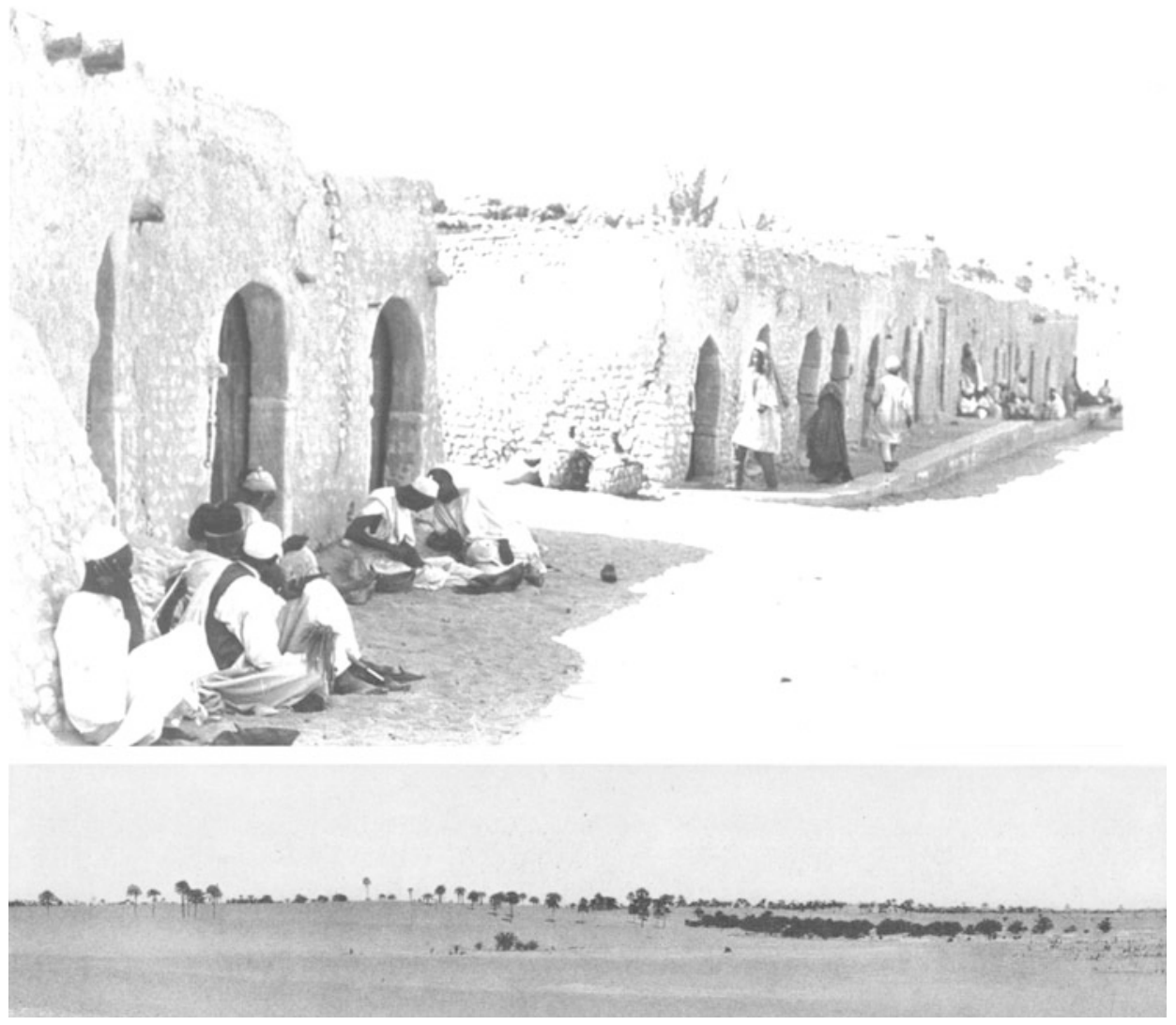

Fig. 6.84 Scenes from Jalu taken from the Archive of the CLAR.HS (above) and the book written by Hassanein Bey in (1924, 242). The geographic explorer Hassanein Bey noted: "Jalo is one of the most important oases in Cyrenaica, partly because of the dates which it produces, but more especially because it is the destination of the caravans coming north from al Kufrah. Ivory and ostrich feathers from Wadai and Darfur come to Jalo to be forwarded either eastward to Egypt or northward to Bengazi. This trade is chiefly in the hands of the Majabra tribe, whose headmen are the - merchant princes of the Libyan Desert. A Majabri (singular of Majabra) boasts that his father died on the basur (camels saddle) in the same way that a soldier boasts that his father died on the held of battle.,"157 


\subsubsection{Jalu-a Spot with a Vibrant Life in the Nineteenth Century}

In the beginning of the nineteenth century, Jalu became one of the most important commercial centres (Figs. 6.83 and 6.84). Sadiq Muayyid al-Azam described the city of Jalu on his way to al Kufrah in 1895 as follows: 'It resembles a small island, at the centre of wide expanses of sand dunes and stony deserts. In it, one finds about two thousand houses and eleven mosques and two zawiyas. It is surrounded on every side by about 76.000 palm trees. Sand dunes and desert vegetation encircle Jalu on all sides'. ${ }^{153}$ But the history of caravan trading in the area goes back much further. Jalu consists of four small villages, the biggest of which being al-Araq, in which most economic and social activities took place. It represented the centre of the oasis region which, apart from Jalu, comprises the two oases of Awjilah and Jakhra. Next in importance after al-Araq, and to the east of it, is the village of al-Libba, which is actually an extension of al-Araq. The two remaining villages are ash Sharaf and Rashida. Ash Sharaf is situated west of al-Araq, whereas Rashida is to the east of it. al-Araq is considered the principal centre from which all caravan routes branched out, linking the oasis with other areas like Banghazi, al Kufrah, al Jaghbub, Maradah, Awjilah, Jakhra and the southern commercial centres in the Fezzan region and in the Sudan. Since antiquity, it was renowned as a main caravan trading centre, enabling its inhabitants to establish strong ties with African countries. These inhabitants not only managed caravans, but also opened and established a number of tracks, such as the "track of the forty" or the Majabira track. The inhabitants of Jalu, or the Majabira, as they are called, soon controlled the trade paths leading to the Sudan, especially after the prohibition of the slave trade, which constituted important revenue to caravan traders. On their way to the Sudan, the caravans of the Majabira used to pass through the areas of Adiri, Anbadi and the Lake Chad region, where they were engaged in commercial activity. The Majabira possessed three commercial houses inhabited by families from Jalu. One of these houses was situated in the Majabira valley, the second one in Kardasa, near Cairo, and the third one in Zawilah or Murzuq, in Fezzan. Hides constituted the most important merchandise sold in this region. ${ }^{154}$

The Jalu oasis derives its water reserves from the water table which is close to the ground. This water tends to be salty, and the salt level in some wells renders their waters unpalatable. Nevertheless, the inhabitants drank this water. Some of them fetched sweet water from the Abu at-Tifl wells, situated about eight hours away from the city. The waters of these wells are sweeter than those of the al-Qimmi and Masliywa wells situated within the oasis. The wells of the oasis are distributed among Jalu's four villages.
Moreover, there are other wells in the al-Gibli, Banus and Ghuratla areas, and their water is similar to those of the other wells of the oasis.

Jalu has a number of historical monuments representing different historical periods. Among them one finds the ancient circular burial grounds in the Nasha area. These cemeteries are in the form of well-ordered high circular wells. Moreover, in various locations one comes across fossilised palm trees. Among Jalu's most renowned historical buildings are the so-called four fortresses, called Hiri, Yanbus, Ghardafat and ash Sharaf, respectively. A number of inscriptions have been found on them.

The people of Jalu belong to the Majabira Arab tribes, who colonised the oasis since the first phase of the Islamic conquests. However, in view of long-lasting and intense commercial activity between Jalu and the Sudan, and the inhabitants' intermarriages with Sudanese women, their skin became darker and their body features changed.

Most of the inhabitants of the oasis used to engage in agriculture. Dates were considered the most important commodity, apart from other agricultural produces such as grain, barley, white and yellow corn and some vegetables. Nevertheless, the agricultural production, especially the cereal production, did not suffice for the local consumption. Hence, the oasis depended on the importation of additional quantities of products from the nearby coastal cities. Moreover, they inhabitants of the oasis practised cultivation on dry land in the southern regions of the Green Mountains which registered considerable rainfall. For this reason, at the end of summer or the beginning of autumn, a number of inhabitants from the oasis moved to the northern regions, near the coast, to plough and sow cereals, particularly grain and barley, relying on the rainy seasons. They then returned to their fields during harvest time to collect their produce. With regard to agriculture within the oasis, they relied on tomatoes and some other products of limited productivity, such as pepper, turnips and other products for local consumption. ${ }^{155}$

\subsubsection{Declining Significance of the Trade}

Of course the inhabitants were engaged in trade, transport of merchandise, and they were also acting as caravan guides directed southwards or eastwards. That was because the city of Jalu was considered a main caravan trading station. The inhabitants of the oasis were considered among the first people, who drove trade caravans along the longest distance linking the Mediterranean coasts with central and eastern Africa. The traders of the region established trade and marriage relationships with the inhabitants of Bornu, Timbuktu, Kano, Murzuq, Zawilah, Soknah, Ghat and al Kufrah. Within the local market of the oasis, as well as between the 
trade caravans reaching the oasis from all directions, the traders exchanged such Western commodities as textiles and woven products and domestic appliances on the one hand, and slaves, ivory, feathers, ostrich eggs, incense and perfumes on the other hand. The people of Jalu had become famous for their trade with the Sudan and central Africa. Trade exchange brought great revenue to the African continent. With the prohibition of slave trade and with the imposition of restrictions on the trading of some commodities, trade activity declined. Similar to the fate of other oases, Jalu lost its importance as a commercial centre linking the north and the south. Moreover, the inhabitants' agricultural activity became very restricted due to the limited fertility of the land and inadequate water reserves. Nevertheless, date palms still constitute an important source of revenue for the inhabitants of the oasis. ${ }^{156}$

\subsection{Al Kufrah—the Travellers' Dream}

\section{Said Hamid}

The city of al Kufrah is located in the south-eastern region of Libya, south-east of the city of Banghazi. Both cities are linked by an road of about $1000 \mathrm{~km}$ which goes through Ajdabiya, Awjilah and Jalu. al Kufrah lies at the intersection of latitude $24.10^{\circ}$ north and longitude $23.05^{\circ}$ east.

Deeply located as it is in the desert, al Kufrah did not attract the attention of the Arab travellers and geographers of the early Islamic centuries or of the Middle Ages. Nonetheless, it was ranked among the biggest stations on the caravan roads in the south-east of Libya. al Kufrah is made up of a number of oases in the very heart of the Sahara desert and is considered to be the most important of them all. The other oases are al-Hawari, al-Hwawiri, al-Tullab, at-Tlaylib and al-Juf. The closest oasis to al Kufrah is the Bazima oasis, which is located $120 \mathrm{~km}$ in the north-west. al Kufrah is also linked to Tazerbu in the north-west via a road of $240 \mathrm{~km}$ long and which passes through the Bazima oasis. The distance between al Awaynat, in the south-east, and al Kufrah is approximately $350 \mathrm{~km}$.

\subsubsection{Hard to Get to}

Many foreign travellers dreamed of reaching al Kufrah. Hassanein Bey, an Oxford-educated Egyptian explorer who accompanied the travel writer Rosita Forbes to the al Kufrah oases in 1920, has pointed out in his book The lost oases: "(...) that it has been said by explorers that the tribes of Cyrenaica, who are all under Sanussi influence, are actuated by religious fanaticism when they refuse foreigners permission to enter their territory. To my great interest, however, I discovered that not religious, but patriotic, fervor is the impelling principle. Their reasoning is simple. They do not want any aliens to come into the country, for they say foreigners mean domination, domination means paying taxes, and they do not want to pay taxes! Therefore, the best way to avoid taxes is to prevent any stranger from entering the region." $" 158$ Therefore, no outsiders, but especially no Christians, were permitted to enter the area.

The first European who succeeded in reaching the remote oases was the German traveller Rohlfs who arrived there in 1879. But he was an exception. After long negotiations with the Zuwaya shaykhs (Fig. 6.85), they agreed to provide guides for Rohlfs'expedition. His small caravan managed to cross the waterless desert between Jalu and al Kufrah in a

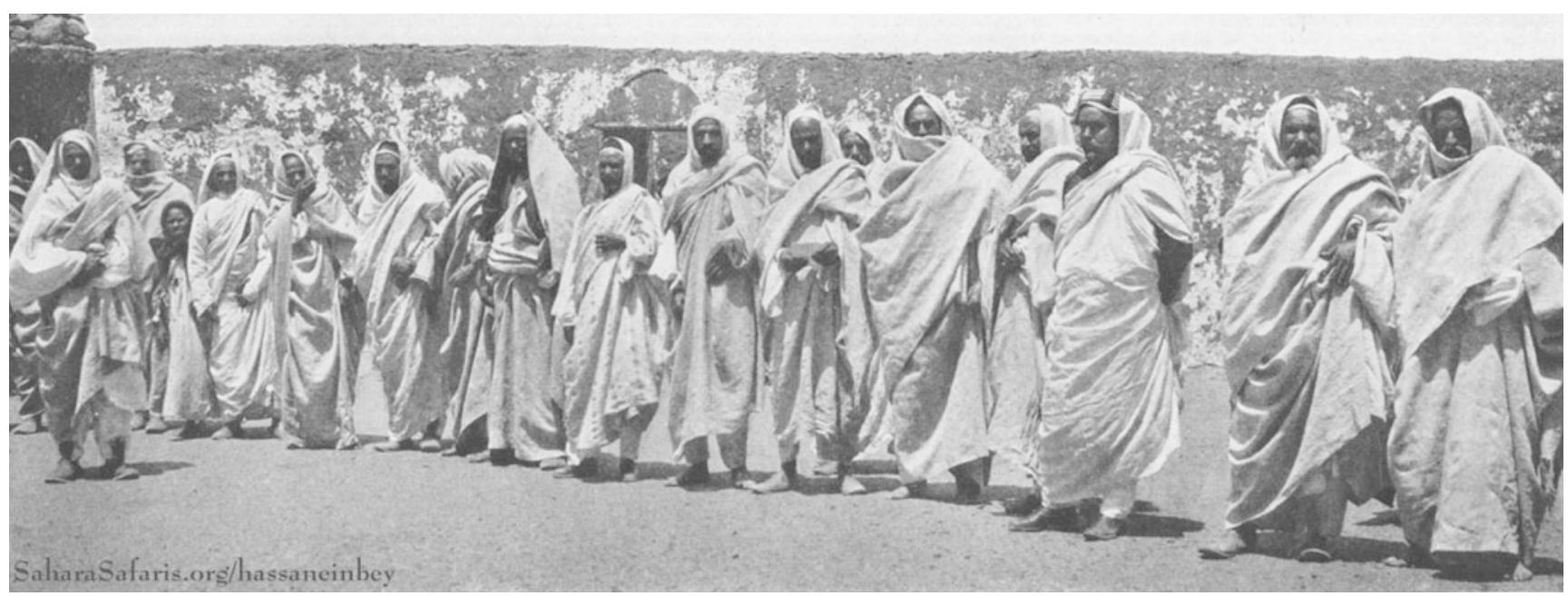

Fig. 6.85 Zuwaya chiefs of al Kufrah as photographed by Hassanein Bey (1924). The Zuwaya are the conquerors of al Kufrah and the inhabitants of it now. They are the tribesmen, who destroyed all the notes and scientific results of the German explorer Rohlfs, when he visited them in 1879 
record five days. But when the suspicious tribesmen, who inhabited al Kufrah, tried to attack him, he escaped with little more than his life. All his notes and scientific equipment were destroyed, and only the arrival of a messenger from the shaykh of the Sanussis in Jaghbub prevented him from being killed. Nevertheless, he managed to describe the al Kufrah oasis, the roads leading to it from different directions, and the oasis' economic and social conditions. ${ }^{159}$ Hassanein Bey noted: "But when I, a Moslem, the son of a religious man and a friend of their head man, arrived, they scratched their heads. Here was a foreigner whom they did not want, but they could not convict him on religious grounds. I had to be tolerated, temporarily at any rate". ${ }^{160}$

The traveller Sadiq Muayyid al-Azam visited al Kufrah in 1895. He then published a book about his journey, highlighting the economic and social conditions of the oasis. The author stated that the al Kufrah oasis was situated halfway between Banghazi and the Wadai kingdom. For this reason, al Kufrah was an important station for caravans coming and going to Wadai and other African kingdoms in its vicinity. All caravans would meet et al Kufrah. As a result thereof, it was very important commercially because it connected the north with the south and vice versa. ${ }^{161}$

\subsubsection{The Importance of the Sanussi Brotherhood}

The al Kufrah oasis derived its importance from its distinctive location and also from the availability of groundwater, which was found close to the surface. In fact, in some places, lakes of sweet water were formed (Figs. 6.86 and 6.87). The various types of plants growing in the oasis provided ideal pastures for camels. The road that linked Ajdabiya, Awjilah, Jalu, Bazima, al Kufrah and al Awaynat could have been a main artery leading deep into the desert, but the long distances between the watering holes limited its regular use during the Middle Ages. ${ }^{162}$ Another significant obstacle for trade was raids committed by tribes east and west of the Cyrenaica. However, with the institution of the
Sanussi brotherhood, al Kufrah became an important trading centre, where traders exchanged different goods and where several trade routes crossed. According to Bey, it has been estimated that between a million and a half and three million people owed allegiance to the Sanussi brotherhood when el Mahdi became its active head. He saw that there was more scope for the influence of the brotherhood to the southward, and in the year 1894, he removed his headquarters from Jaghbub to al Kufrah. This move marked not only the beginning of an important era in the history of the Sanussi, but also in the development of trade between the Sudan and the Mediterranean coast by way of al Kufrah. Under the rule of the Zuwaya tribe of Badawi, who had conquered al Kufrah from the black Tubus, the group of oases was the chief centre of brigandage in the Libyan Desert. ${ }^{163}$

During the first half of the nineteenth century, the al Kufrah road was hit by an earthquake. Subsequently, less caravans used it due to the lack of security along its track. This situation lasted for 15 years, after which the road recovered its importance as security and stability were restored during the middle part of the same century.

\subsubsection{Caravan Roads that Linked al Kufrah to the Cities of the Mediterranean Coast and the South:}

\begin{tabular}{l|l}
\hline $\begin{array}{l}\text { Linking al Kufrah to the } \\
\text { Mediterranean coast: }\end{array}$ & Linking al Kufrah to the south: \\
\hline $\begin{array}{l}\text { Sirte, Tagreft, Zillah, Tazirbu, } \\
\text { Bazima, al Kufrah } \\
\text { Banghazi, Ajdabiya, Awjilah, } \\
\begin{array}{l}\text { Jalu, Tazerbu, Bazima, al } \\
\text { Kufrah } \\
\text { Marsa Lak, Siwa Santriyya, al } \\
\text { Kufrah }\end{array}\end{array}$ & $\begin{array}{l}\text { al Kufrah, al Awaynat, } \\
\text { al-Athrun, Waddai or the } \\
\text { Sudanese cities } \\
\text { al Kufrah, Tibesti, Uzu, Kawar, } \\
\text { Ghadāmis }\end{array}$ \\
\end{tabular}

There were also two roads, one going towards the east, to Egypt, and the other to the west, towards Rebyana, to Waw an-Namus, Waw al-Kabir, Zuweyla, Sabha. Here, it connected to the northern road, or the road coming from

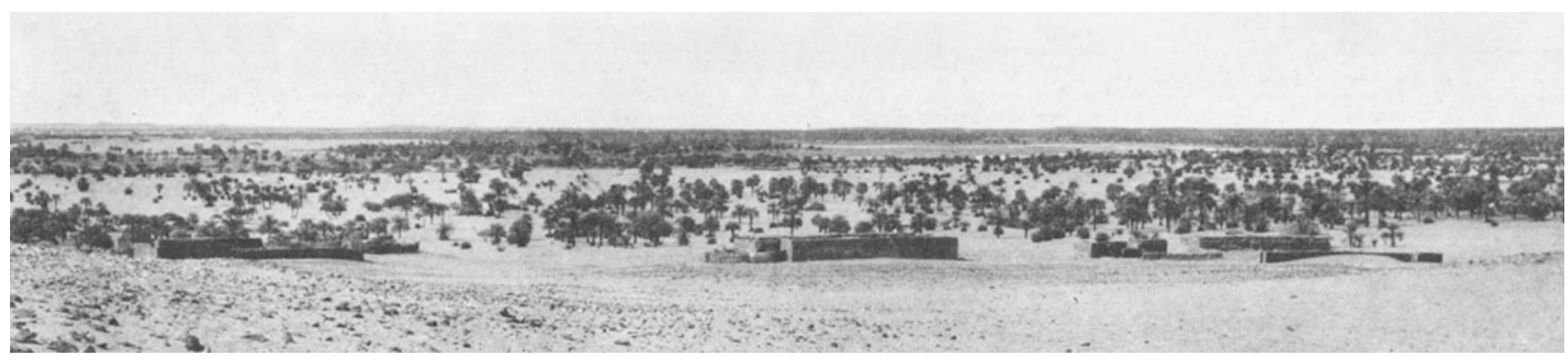

Fig. 6.86 Date palms in the valley of al Kufrah. In the middle distance, the light streak is the lake of al Kufrah. In the foreground are the dwellings of the natives (Hassanein Bey 1924, 244) 

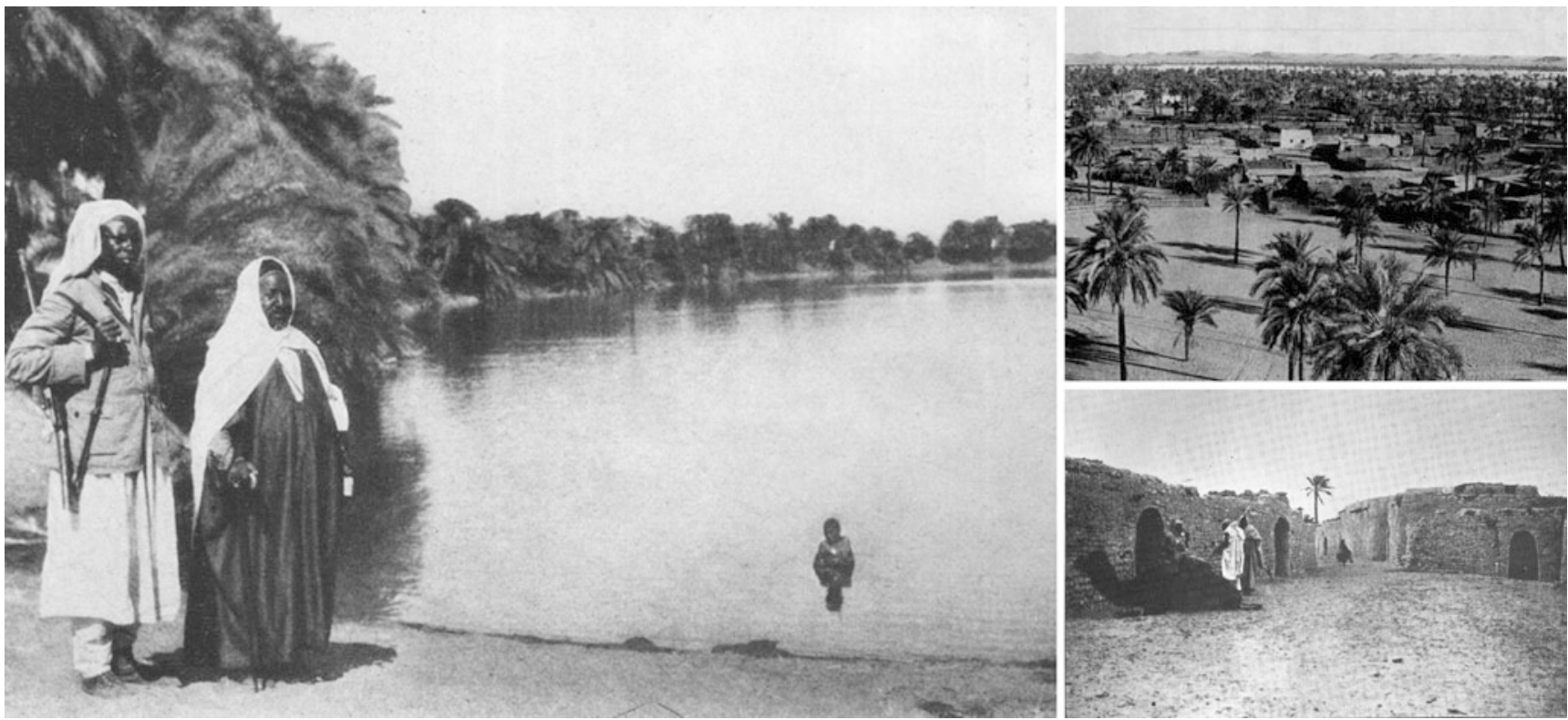

Fig. 6.87 Scenes from al Kufrah taken from the book written by Hassanein Bey (1924). The saltwater lake at al Kufrah covers an area of two square miles, and it is very deep in the centre. The oasis surrounds the lake. In the foreground, it is one of the notable Bedouin chiefs of al Kufrah and one of the Sanussi soldiers. When Hassanein Bey asked this chief if there were fish in the lake, he replied: "What is a fish? Does it walk? Does it fly?" He found it to be almost impossible to describe a fish to a person who had never seen one (Hassanein Bey 1924, 246). Hassanein Bey stated: "The approach of al Kufrah from the north has an element of surprise in it that makes it doubly interesting. We marched through gelly rolling country with an irregular ridge of no great height forming the horizon. Suddenly the top of the ridge resolved itself into the outlines of a group of buildings, their walls hard to distinguish at any distance from the rocks and sands they match so weil in colour and in form. This is al Taj, the headquarters of the Sanussi family in al Kufrah. As we enter the town, we see that the ground drops abruptly away beyond it, down to the valley of the al Kufrah. This pleasant valley is a shallow, roughly oval bowl, $40 \mathrm{~km}$ on its long diameter in extent and up to $20 \mathrm{~km}$ on the short one. It is dotted with palm trees, and across it in an irregular line from north-east to south.west are strung the six settlements of Boema, Buma, Jof, al Zurruk, Tallalib, and Tollab. Near Jof lie the blue shimmering waters of a lake of large extent. At this point in the sand waste of the desert, this expanse of water is both a boon and an aggravation. Unfortunately, its waters are salty. However, one can swim in it with a pleasure unknown in the land of sea and river and bath-tubs." Hassanein Bey started exploring the valley of al Kufrah: "I visited the villages, the Suk where the weekly market is held, and the Zawya at Jof, which is the oldest Sanussi school and the first building erected in al Kufrah. It was interesting to find side by side in the Suk rille cartridges whose marking shows them to be thirty years old, ltalian tomato sauce in tins from Banghazi, blue and white calico from Egypt, and leather, ivory, and ostrich feathers from Wadai. These products of the south, however, are not plentiful now in al Kufrah, except when a merchant who has brought them from Wadai is prevented for some reason from going on to the north to sell them in Egypt or Cyrenaica". ${ }^{166}$

Zuweyla to al Qatrun, Madrusah, Tajarhi, Sajdin, Kuwar and Kuka.

Until the beginning of the twentieth century, al Kufrah used to receive one caravan every week. The number of camels making up such caravans varied between one hundred and three hundred, carrying hides, ivory and ostrich feathers from central and western Africa towards the Mediterranean coasts. The use of this road came to an end with the Italian occupation of Libya in $1911 .^{164}$

\subsubsection{Al Kufrah at the Dawn of the Twentieth Century}

At the beginning of the 1920s when Hassanein Bey was visiting the oasis, he noticed that "in addition to the trade that passes through al Kufrah, most of the big Zuwaya chiefs go in for agriculture. They raise barley and maize. The
Sanussi are more progressive, and grow melons, grapes, bananas, marrows, and other vegetables of the more delicate kinds, all of which are a great treat after the monotonous fare of the desert. They also raise mint and roses, from which they make rose-water and mint essence, so essential in their ceremonies of hospitality. From a few olive trees olive oil is produced in primitive presses. But dates are the main item in the Badawi's diet, and there are many date trees all through the al Kufrah valley. Dates are the only article of exportation from the oases, but for other commodities, whether for food or clothing, al Kufrah is mainly dependent on the outside world. Tea, sugar, rice, flour, and white calico are the main imports of al Kufrah. The Badawi live a simple and primitive life, sheltered in houses built of stone, plastered and whitewashed inside. A roughly made divan, covered with cushions and Badawi rugs, made in the north, is the only furniture one comes across in these small houses. In a rich man's house the reception room is covered 
with Persian rugs and expensive silk cushions. A gramophone with discs of Arab songs by Egyptian singers is the rich man's luxury." But what is very interesting to read is that "manual work is done mostly by slaves. The price of slaves, learnt at al Kufrah, has risen a great deal during the last few years because there are no more slaves coming up from Wadai on account of the vigilance of the French authorities in that province." Hassanein Bey reports that the Badawi sometimes marry their slave-girls, "and if one of these bears a male child she automatically becomes free. The Badawi have no prejudice against colour, that is, if a slave bears the head of a tribe his eldest male child, that child ipso facto becomes in his turn the head of the tribe, however black he may be. On the whole slaves are weil treated by the Badawi. They are weil dressed, for an illdressed slave reflects badlyon his master." 165

Towards the end of the twentieth century, al Kufrah saw an increase in camel trading. Herds of camels without any loads assembled at al Kufrah, and from here, they were then transported on trucks to other Libyan cities and sold for their meat (see Fezzan as a Transit Region in the Late twentieth and at the Dawn of the twenty-first Century).

\section{Notes}

1. Di Vita et al. (1999), Di Vita (1996, 173-190), Mattingly (1995, 122-125), Kenrick (2009b, 16-34).

2. Mattingly $(1995,123)$.

3. Micara $(2008,387)$, Ciranna $(2017,67)$.

4. Rossi (1913-1936), Oman (2010, 2012).

5. Micara (2008, 385), Al-Tijani, Rihlah, in Rossi (1968, 76), al Tijani (1852).

6. Al-Tijani (1852).

7. Halm (1992, 129-157), Khalilieh (1999, 212-225), Salama (1995, 72f), al Khouja (2007, 32, 130).

8. Rossi $(1968,112)$, Micara $(2008,387)$.

9. al Khouja $(2007,6,63)$.

10. Wright $(2005,20)$.

11. Micara $(2008,388)$.

12. Micara $(2008,391)$, Administration of the Historical Cities (2010).

13. Micara $(2008,391 f)$.

14. al Khouja $(2007,35,42,48)$, Administration of the Historical Cities (2010).

15. Micara $(2008,394-395)$.

16. al Khouja (2007, 35, 42, 48), Administration of the Historical Cities (2010).

17. al Khouja (2007, 20, 42, 75), Administration of the Historical Cities (2010).

18. Salama (1995, 31f, 44f).

19. Micara $(2008,396)$.

20. Wright $(2005,45 f)$, Tully $(2009,6)$.

21. Wright $(2008,153)$.
22. Wright $(1989,48 f)$.

23. Wright $(1989,48)$, Dearden $(1957,160)$.

24. Lyon $(1821,12)$.

25. Piazza (1996, 139-173), Micara (2008, 397-398).

26. Cowper $(1897,11)$.

27. Rae (1877, 19-21).

28. Piazza (1996, 139-173), Micara (2008, 397-398).

29. Micara $(2008,402)$.

30. al Khouja (2007, 33, 43).

31. al Khouja $(2007,104)$.

32. Salama (1995, 47f), al Khouja (2007, 132).

33. Greenhow $(1835,52)$.

34. Greenhow $(835,3)$, Bosworth $(2007,533 f)$.

35. Rohlfs $(1871,84)$.

36. Rohlfs $(1881,77)$.

37. Banse (1912).

38. Herzog $(1961,255-262)$.

39. Krause $(2014,34)$.

40. Krause $(2014,82)$.

41. Krause $(2014,71)$.

42. Krause $(2014,71)$.

43. Krause $(2014,82)$.

44. McLaren (2006, 223).

45. Christides et al. (2007, 534), Altekamp (2000, 1998).

46. McLaren (2006, 98), Altekamp (2000).

47. McLaren (2006, 98), Schieder (2006, 707).

48. McLaren (2006, 98), Altekamp (2000).

49. Barth $(1849,295)$.

50. Rohlfs $(1871,32)$.

51. Rohlfs $(1871,82)$.

52. al Khouja (2007, 34).

53. Altekamp (2000, 249).

54. Hamed (2008, 24-37).

55. Altekamp (2000, 191-200, 249-253), see also Altekamp (1998, 159-175), Altekamp (1999, 80-103), and McLaren (2006, 94-103).

56. Altekamp (2000, 194f) and McLaren (2006, 94-103).

57. Braun and Passon (2010), Bianca (2000).

58. Hawqal, A Picture of the Earth, al Bakri, al Mughrib in the mention of the countries of Ifriqiah and Maghreb, a Part of the Book of al Masalik Wal Mamalik, Baghdad, Ash Shammakhi (1995), Goodchild (1999), Hamid (1978), Hamid (2005).

59. Haynes $(1955,36)$.

60. Goodchild (1954, 76).

61. Despois (2012).

62. Khaldun (1867), Band 7, $58 \mathrm{f}$.

63. Leo Africanus $(1984,191)$.

64. Helfensteller $(1998,87)$.

65. Richardson $(1848,88)$.

66. Chavanne $(1879,221)$.

67. Rohlfs $(1984,62)$. 
68. Evans $(1976,31)$.

69. Chavanne (1879, 222f).

70. Rohlfs $(1984,63)$.

71. Chavanne (1879, 232).

72. Schliephake $(1982,286)$.

73. Ahmad (1969, 145f), Despois (2012).

74. Richardson $(1848,92)$.

75. Ahmad (1969, 148f).

76. Rohlfs $(1984,69 f)$.

77. Richardson $(1848,90)$.

78. Evans (1976, 31ff).

79. Rohlfs $(1984,66 f)$.

80. Eldblom $(1968,1 \mathrm{ff})$.

81. Despois (2012).

82. Chavanne $(1879,234)$.

83. Rohlfs (1984, 68ff).

84. Despois (2012).

85. Schliephake $(1982,289)$.

86. Eldblom (1969, 3-8).

87. Passon (2008).

88. McLachlan (2012), Az Zawi (1968), Diary of a Tripoli caravan to Wadday, Rohlfs (1856-1867), Transportation routes in Tripoli, Mattingly (translated by Center for the Libyan Archives and Historical Studies), Nachtigal (translated by Center for the Libyan Archives and Historical Studies), al Arabi, Terry (2004, 2008).

89. Miludi.

90. Barth (1890, 45ff), Az Zawi (1968), Terry (2004, 2008).

91. Terry (2004, 2008), Goodchild (1999); al Barghuthi (1971), Az Zawi (1968), Abbas (1968), An Nims (1978), Haynes (1981).

92. Ad Dinasuri (2004), Terry (2004, 2008), Sharaf (1962).

93. al Bakri; Terry (2004, 2008), Ad Dinasuri (2004), Sharaf (1962), Ayyub (1963).

94. al Idrisi; Rohlfs; Ad Dinasuri (2004), Az Zawi (1968), al Mahdawi; al Mawsili.

95. Weis (1996).

96. Martin (1985, 61-76).

97. Rohlfs (1874), Chap. 6.

98. Barth (1857).

99. Rohlfs (1874), Chap. 7.

100. Wirth $(2000,97 f)$.

101. Weis (1996).

102. Barth $(1857,180)$.

103. Nachtigal $(1879,92)$.

104. Rohlfs (1874), Chap. 7.

105. Nachtigal (1879, 93f and 133f).

106. Barth (1857), Nachtigal (1874), Rohlfs (1874).

107. Nachtigal $(1879,130)$.

108. Barth $(1857,180)$.

109. Weis (1996).
110. Rohlfs (1874).

111. Barth, 177f, Nachtigal $(1879,73)$.

112. Rohlfs (1874), Chap. 7; Wirth (2000, 103ff).

113. Chavanne (1879).

114. Eldblom (1968, 314f), Martin $(1985,63)$.

115. Nachtigal (1879).

116. Weis (1996).

117. Passon (2008, 222-226).

118. Terry (2004, 2008), Hamid (2006).

119. al Idrisi (1981, 120).

120. Hamid (2006), Sharaf (1962).

121. Hamid (2006).

122. Mattingly et al. $(2009,151)$.

123. Hamid (2006), Ayyub (1993).

124. Mattingly et al. $(2009,151)$.

125. Hamid (2006), The Tarikhuna encyclopedia supervised by Sadeq an Naihoum.

126. Hakam (1968), al Ansari et al. (1967), Ayyub (1993), al Barghuthi (1972), Terry (2004, 2008).

127. Despois (2012).

128. Krause (1998); Hasan: Studies in the Geography of Libya and the Arab World; Az Zawi (1968); A map from the book of A. G. Hopkins: The Economic History of Arab Africa (translated by Ahmad Fuad Balba) 1998; Terry (2004, 2008); Despois (2012).

129. Terry (2004, 2008), Az Zawi (1968), Sharaf (1962), al Azm (1998).

130. Terry $(2004,2008)$, Sharaf (1962), Ad Dinasuri (1967).

131. Terry $(2004,2008)$.

132. Hawqal, A Picture of the Earth, Beirut.

133. Khaldun (1284); Hakam (1983); al Bakri in the Mention of the countries of Ifriqiah and Maghreb; Terry (2004, 2008), Goodchild (1999), Hamid (1978), Hamdani; Abbas and Najm (1968), Fehr Fari (19771981).

134. Goodchild (1970), Wright (2007, 104), Lequien (1740, 623-626).

135. Wright (2007, 103-105), Cordell (1977, 21-22), Baier (1978, 27-28).

136. al Buri (2004); Brothers Biatci and the Libyan Coast: translated by al Hadi Abu Luqma; al Hashaishi (1965); Mansur: The Arab Travellers and their role in the writing of Libya's Political and Economic History in the Seventeenth and Eighteenth Centuries; Curo: Libya During the Second Ottoman Era; al Azm (1998); al Fituri: Libya and the Caravan Trade; Bazama: Banghazi through History; Rohlfs (translated by Center for the Libyan Archives and Historical Studies); Hamid (2008).

137. Hawqal: A Picture of the Earth; Hakam (1968); al Bakri in the Mention of the countries of Ifriqiah and 
Maghreb; Terry (2004, 2008), al Ayyashi (1977), Abbas and Najm (1968), Hamid (1991), Belhaj (1968).

138. Prestopino $(1999,123)$.

139. Hawqal: A Picture of the Earth. Hakam (1968); al Bakri in the Mention of the countries of Ifriqiah and Maghreb; Terry (2004, 2008), al Ayyashi (1977), Abbas and Najm (1968), Hamid (1991), Belhaj (1968).

140. Hawqal: A Picture of the Earth.

141. Levtzion and Hopkins $(2000,104)$.

142. Hawqal: A Picture of the Earth; Hakam: The conquest of Egypt and the Maghreb; al Bakri in the Mention of the countries of Ifriqiah and Maghreb; Terry (2004, 2008), al Ayyashi (1977), Abbas and Najm (1968), Hamid (1991), Belhaj (1968).

143. Hakam: The conquest of Egypt and the Maghreb; Terry (2004, 2008), al Ayyashi (1977), Rohlfs (2002): Across Africa (translated by the Center for the Libyan Archives and Historical Studies); Abbas and Najm (1968), al Sayyad and Hamid (1976); Department of Antiquities (1976).

144. Hawqal: A Picture of the Earth.

145. al Bakri in the Mention of the countries of Ifriqiah and Maghreb.

146. Hakam: The conquest of Egypt and the Maghreb; Terry (2004, 2008), al Ayyashi (1977), Rohlfs (2002): Across Africa (translated by the Center for the Libyan Archives and Historical Studies); Abbas and Najm (1968), al Sayyad and Hamid (1976); Department of Antiquities (1976).

147. Assuwais (2000).

148. Rohlfs: A journey to al Kufrah (translated by The Center for the Libyan Archives and Historical Studies).

149. The Islamic Encyclopedia; Assuwais (2000), al Aqil (2000); Rohlfs: A journey to al Kufrah (translated by Center for the Libyan Archives and Historical Studies);
Pashu: Narration of a trip to Marmara, Corina, and the oases of Aujal and Marada; Ash Sharief (1988); Hamid: The ancient history of the Aujala oasis up to the Ottoman era; Sharib: The caravan trade and its relation to the Aujala oasis.

150. Hornemann (1802).

151. The Islamic Encyclopedia; Assuwais (2000), al Aqil (2000); Pashu: Narration of a trip to Marmara, Corina, and the oases of Aujala and Marada. Ash Sharief (1988); Hamid: The ancient history of the Aujala oasis up to the Ottoman era; Sharib: The caravan trade and its relation to the Aujala oasis.

152. Sharaf (1962).

153. al Azm: A Journey in the Great Desert in Africa (translated by Center for the Libyan Archives and Historical Studies).

154. Terry (2004, 2008); Rohlfs: A Journey from Tripoli to Alexandria (translated by Center for the Libyan Archives and Historical Studies); Mansur: The Arab Travellers and their role in the writing of Libya's political and economic history.

155. Terry $(2004,2008)$.

156. Mansur: The Arab Travellers and their role in the writing of Libya's political and economic history.

157. Hassanein Bey (1924).

158. Hassanein Bey (1924).

159. Rohlfs: Across Africa (translated by Center for the Libyan Archives and Historical Studies).

160. Hassanein Bey (1924).

161. al Azm (1998), Pasha (2006).

162. Sharaf (1962).

163. Terry $(2004,2008)$, Hassanein Bey $(1924,278)$.

164. Sharaf (1962).

165. Hassanein Bey $(1924,289)$.

166. Hassanein Bey (1924, 287-288).
Open Access This chapter is licensed under the terms of the Creative Commons Attribution 4.0 International License (http:// creativecommons.org/licenses/by/4.0/), which permits use, sharing, adaptation, distribution and reproduction in any medium or format, as long as you give appropriate credit to the original author(s) and the source, provide a link to the Creative Commons license and indicate if changes were made.
The images or other third party material in this chapter are included in the chapter's Creative Commons license, unless indicated otherwise in a credit line to the material. If material is not included in the chapter's Creative Commons license and your intended use is not permitted by statutory regulation or exceeds the permitted use, you will need to obtain permission directly from the copyright holder. 